\title{
THE ZINC FERTILITY \\ OF SASKATCHEWAN SOILS
}

\section{JAI PAL SINGH}

1986 
THE ZINC FERTILITY OF SASKATCHEWAN SOILS

\author{
A Thesis \\ Submitted to the Faculty of Graduate Studies and Research \\ in Partial Fulfillment of the Requirements \\ for the Degree of \\ Doctor of Philosophy \\ in the \\ Department of Soil science \\ University of Saskatchewan \\ by \\ Jai Pal Singh \\ Saskatoon, Saskatchewan, Canada \\ JuIy, 1986
}

ce Copyright J.P. Singh 1986 
The author has agreed that the Library, University of Saskatchewan, may make this thesis freely available for inspection. Moreover, the author has agreed that permission for extensive copying of this thesis for scholarly purposes may be granted by the professor or professors who supervised the thesis work recorded herein or, in their absence, by the Head of the Department or the Dean of the College in which the thesis work was done. It is understood that due recognition will be given to the author of this thesis and to the University of Saskatchewan in any use of the material in this thesis. Copying or publication or any other use of the thesis for financial gain without approval by the University of Saskatchewan and the author's written permission is prohibited.

Requests for permission to copy or to make any other use of the material in this thesis in whole or in part should be addressed to:

Head of the Department of Soil Science

University of Saskatchewan

SASKATCON, Saskatchewan

Canada S7N OWO 


\section{ABSTRACT}

Field, growth chamber, and Iaboratory studies were conducted to investigate the zinc fertility of Saskatchewan soils. These studies included an examination of $Z n$ spatial variability, a survey of DTPAextractable $\mathrm{Zn}$ levels of soils from across the province, a variety of experiments on $\mathrm{Zn}$ fertilizers, and investigations on the mechanisms of $P X$ $\mathrm{Zn}$ interaction in wheat (Triticum aestivum L.) and beans (Phaseolus vulgaris L.). In addition, the distribution and plant availability of native and applied $\mathrm{Zn}$ in various soil $\mathrm{Zn}$ fractions were investigated in three soils that varied widely in physical and chemical properties.

DTPA-extractable micronutrients ( $\mathrm{Zn}, \mathrm{Cu}, \mathrm{Mn}$ and $\mathrm{Fe}$ ) in fields of level topography showed a high degree of variability in samples taken along transects and geostatistical analyses (semivariograms) indicated that the extractabie micronutrients were randomly distributed. In contrast, DTPA-extractable $\mathrm{Zn}$ and tissue $\mathrm{Zn}$ concentration in undulating topography showd spatial structure with a range of $25 \mathrm{~m}$ in all except one of the transects considered. DTPA-extractable $\mathrm{Zn}$ and organic $\mathrm{C}$ levels were highly correlated and had similar spatial structure.

Current criteria for predicting $\mathrm{Zn}$ deficiency in Saskatchewan soils are based on DTPA-extractable $\mathrm{Zn}$ values. DTPA-extractable $\mathrm{Zn}$ levels in $12 \%$ of $1200 \mathrm{samples}$ taken across Saskatchewan contained $<0.5 \mathrm{mg} \mathrm{Zn} \mathrm{kg}^{-1}$ soil and would be classified as potentially $\mathrm{Zn}$ deficient. However, 23 field trials in 1982, 1983 and 1984 with spring wheat (Triticum aestivum L.), barley (Hordeum vulgare L.), lentils (Lens esculenta Moench.), peas (Pisum Sativum L.), alfalfa (Medicago sativa L.), corn (Zea mays L.), and flax (Linum usitatissimum L.) produced only one significant response to $\mathrm{Zn}$ 
fertilization.

The relative effectiveness of $\mathrm{ZnSO}_{4}$, ZnEDTA, low-yield ammoniumbased I ignosul phonate ( $\mathrm{ZnLY}$ ) and high-yield ammoni um-based I ignosul phonate (ZnHY) for bean production was tested in growth chamber and incubation experiments. ZnLY was more effective than ZnEDTA and ZnHY in correcting $\mathrm{Zn}$ deficiency of bean plants. While biomass production was best with $\mathrm{ZnSO}_{4}$, ZnLY was more effective in increasing $Z n$ content of the foliage.

Eield and growth chamber studies were carried out to elucidate the mechanisms of $\mathrm{P} X \mathrm{Zn}$ interaction in the nutrition of wheat and beans, respectively. In the field, residual $P$ levels from 80 or $160 \mathrm{~kg} \mathrm{P} \mathrm{ha}^{-1}$ applied in 1979 to a Sutherland soil (Dark Brown Chernozemic) increased wheat yield significantly. In the presence of $P$, soil and foliage applied Zn in 1984 resulted in significant increase in grain yield and zn uptake into grain. High levels of $P$ in the soil increased tissue $P$ concentration but $\mathrm{Zn}$ concentration was decreased significantly. DTPA-extractable soil $\mathrm{Zn}$ levels in the non- $\mathrm{Zn}$ amended treatment were independent of $\mathrm{P}$ application rate. A close relationship was obtained between $\mathrm{zn}$ levels in the above ground plant parts and vesicular-arbuscular mycorrrhizal (VAM) infection. VAM infection of wheat roots was significantly lower in high $P$ treatments than in the control.

In the growth chamber, the $\mathrm{P} X \mathrm{Zn}$ interaction in roots and above ground parts of bean was studied in the Sutherland (Dark Brown Chernozemic), Carrot River (Dark Gray Chernozemic) and Meota (Black Chernozemic) soils. The $P X Z$ zn interaction on dry matter yield of above ground parts was significant for the Sutherland and Carrot River soils only. Applied Zn increased yield only when $P$ was applied. Application of $P$ reduced $2 n$ concentration in tops below the critical levels at $1 / 10$ bloom 
growth stage in the Sutherland and Carrot River soils. In the 0 applied $\mathrm{Zn}$ treatment, a response was obtained with $P$ application but translocation of Zn from roots to tops was inhibited at both the 80 and $160 \mathrm{mg}$ applied $P$ $\mathrm{kg}^{-1}$. Thus both $\mathrm{Zn}$ dilution in the plant and reduced translocation of $\mathrm{Zn}$ from roots to tops accounted for the $P X$ Zn interaction observed. Phosphorus absorption by roots and accumulation of $\mathrm{P}$ in above ground plant parts was markedly reduced by $\mathrm{Zn}$ application. However, in the absence of applied $\mathrm{Zn}$, $\mathrm{P}$ levels in bean tissue never reached toxic levels.

Native and applied $Z n$ in three soils (used for $P X$ Zn interaction experiment with beans) were separated into water soluble plus exchangeable (EX), specifically adsorbed (ExAD), organically bound (OM), Mn-oxide bound $(M n O X)$, Fe-oxide bound (FeOX) and residual (RES) fractions. The major proportion of native $\mathrm{Zn}$ in all soils was recovered in the RES and FeOX fractions. The EX, EXAD, OM and Mnox fractions accounted for only a small portion of native $\mathrm{Zn}$. In contrast, most of the applied $\mathrm{zn}$ in the Meota and Carrot River soils was recovered in the ExAD fraction, whereas in the Sutherland soil in the $O M$ and FeOX fractions. The amount and percent distribution of applied $\mathrm{Zn}$ in the $O M, F e O X$ and MnOX fractions of all soils varied directly with the organic $C$ and Fe- and Mn-oxide contents, respectively. The distribution of applied $\mathrm{Zn}$ in various fractions was independent of applied $P$. The distribution of applied $\mathrm{Zn}$ in various $\mathrm{Zn}$ fractions in combination with $\mathrm{Zn}$ plant uptake indicated that the $\mathrm{EX}$ and ExAD fractions were the most potentially plant available pools. 


\section{ACKNOWLEDGEMENTS}

The author expresses his sincere appreciation and thanks to Dr. R.E. Karamanos and Dr. J.W.B. Stewart for their supervision and encouragement during the course of this study, and for their guidance and constructive criticism during the preparation of the thesis.

Thanks are also extended to the members of my advisory committee, Prof essors J.J. Germida, E.H. Halstead, J.L. Henry and G. Hughes, for their constructive comments during the course of this study .

I am very thankrul to Fiona Youatt and Hermann Erhart for their assistance with the field and analytical work. Thanks are also extended to Leonard Mah for his assistance in drafting the figures.

I am especially indebted to my wife Piari for her enduring support and enthusiastic encouragement during the completion of this study. I would like to apologize to my children, Sonia, Vishal and Priti with whom I could hardly spend any leisure time. I wish to express my sincere appreciation and thanks to my friends, Drs. $C$. Kishor and R.P. Narwal, and my brother-in-law, Bhagat Singh, for being with my family and my late father through thick and thin.

The financial assistance of the Canadian Commonwealth Scholarship and Fellowship Committee, ottawa, is gratefully acknowledged.

Finally, I would like to thank the Department of soil science, Haryana Agricultural University, Hisar, for providing me study-leave during my stay in Canada. 
Dedicated to my father

Late Sh. Hari Singh 
1. IntRODUCTION ........................

2. LiteratURE REVIEW....................... 5

2.1 Zine in Plant Physiology.................. 5

2.2 Zinc Containing Minerals and Zn Content in Soils... 8

2.3 Zinc species in soil solution.............. 10

2.4 Forms and Distribution of Soil zinc............ 12

2.5 Zinc Adsorption by Soil and Inorganic Constituents.. 16

2.5 .1 whole soils....................... 16

2.5 .2 Layer silicates.................... 19

2.5 .3 oxides and hydroxides.............. 21

2.6 Reaction with organic Matter.............. 24

2.7 Phosphorus $X \mathrm{Zinc}$ Interaction............. 26

2.8 Factors Affecting $z$ Availability ............ 30

2.9 Diagnosis of $\mathrm{Zn}$ Deficiency................ 31

2.9 .1 soil testing $\ldots \ldots \ldots \ldots \ldots \ldots \ldots \ldots \ldots \ldots \ldots \ldots \ldots \ldots$

2.9.2 Plant tissue analysis.............. 34

2.10 Zinc Fertilizers and Correction of Zn Deficiency... 36

3. MATERIALS AND METHODS..................... 39

3.1 Spatial Variability of $\mathrm{zn} \ldots \ldots \ldots \ldots \ldots \ldots \ldots \ldots$

3.1.1 Spatial variability of $\mathrm{Zn}$ in relation to other micronutrients in uniform topography... 39

3.1.2 Spatial variability of $\mathrm{Zn}$ in undulating

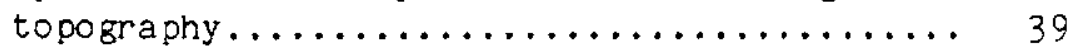

3.1 .3 Soil and plant tissue analyses.......... 41

3.1 .4 Statistical approach............... 41 
3.1.4.1 Classical statistics........... 41

3.1 .4 .2 Geostatistics............. 42

3.2 Importance of $\mathrm{Zn}$ to Crop Nutrition and Production

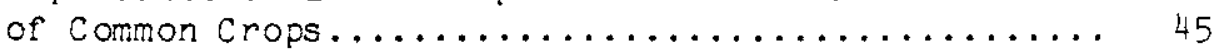

3.2.1 Zinc status of Saskatchewan soils........ 45

3.2.1.1 Exploratory surveys.......... 45

3.2.1.2 Field experiments with $\mathrm{Zn}$

fertilizers................ 47

3.2.1.2.1 Experimental design.... 47

3.2.1.2.2 Soil and plant tissue sampling and analyses.... 49

3.2.1.2.3 Statistical analysis.... 50

$3.2 .2 P \times \mathrm{Zn}$ interaction in wheat........... 50

3.2.2.1 Experimental design.......... 50

3.2.2.2 Soil and plant tissue sampling and anal yses.................... 51

3.2.2.3 Mycorrhizal inf ection......... 52

3.2.2.4 Statistical analyses......... 52

3.2.3 $\mathrm{P} \times \mathrm{Zn}$ interaction in beans........... 52

3.2.3.1 Experimental design........... 52

3.2.3.2 Treatment application.......... 53

3.2.3.3 Establishment of the experiment.... 54

3.2.3.4 Maintenance of the experiment..... 54

3.2.3.5 Plant tissue sampling and analyses.. 55

3.2.3.6 Statistical analysis.......... 55

3.2.4 Effectiveness of zinc fertilizers........ 55

3.2.4.1 Experimental design........... 56

3.2.4.2 Soil and plant tissue sampling and analyses.................... 60 
3.2.4.3 Statistical analysis.......... 60

3.3 Distribution of Native and Appiied Zinc......... 60

3.4 Analytical Procedures................... 62

3.4.1 Soil sample collection and preparation...... 62

3.4.1.1 pH and electrical conductivity.... 62

3.4 .1 .2 soil texture............... 62

3.4.1.3 Cation exchange capacity........ 62

3.4.1.4 $0.5 \mathrm{M} \mathrm{NaHCO}_{3}$-extractable P........ 62

3.4.1.5 Resin extractable P........... 63

3.4.1.6 Inorganic and organic carbon...... 63

3.4 .1 .7 Available zinc............. 63

3.4.1.8 Free $\mathrm{Ee}$ and $\mathrm{Mn} \ldots \ldots \ldots \ldots \ldots \ldots \ldots 64$

3.4.1.9 Zinc fractionation technique...... 64

3.4.1.9.1 Exchangeable (non-

specifically adsorbed)

(EX)............... 65

3.4.1.9.2 Exchangeable (specifi-

cally adsorbed) (ExAD)... 65

3.4.1.9.3 organically bound $\mathrm{Zn}$

(OM)............... 65

3.4.1.9.4 Mn-oxide bound $\mathrm{Zn}$ (Mnox). 65

3.4.1.9.5 Fe-oxide bound $2 n(F e 0 X) .65$

3.4.1.9.6 Residual Zn (RES) ..... 66

3.4 .1 .9 .7 Total zinc......... 66

$\begin{array}{ll}3.4 .1 .9 .8 & \text { Zinc determination in } \\ & \text { soil fractions....... } 67\end{array}$

3.4.2 Plant tissue analysis.............. 67 
4. RESULTS AND DISCUSSION...................... 69

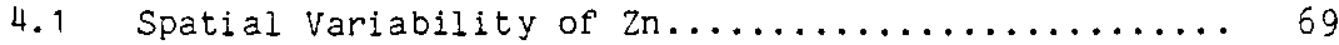

4.1.1 Spatial variability of $2 n$ in relation to other micronutrients in uniform topography... 69

4.1.2 Spatial variability of $\mathrm{Zn}$ in undulating

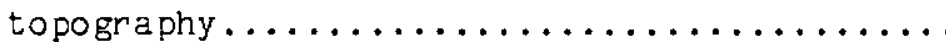

4.2 Importance of 2 n to Crop Nutrition and Production of Common Crops......................... 94

4.2 .1 Zinc status of Saskatchewan soils.......... 94

4.2.1.1 Exploratory surveys........... 94

4.2.1.2 Field experiments with $\mathrm{Zn}$

fertilizers................. 95

4.2.2 P X Zn interaction in wheat.......... 108

4.2.2.1 Yields...................... 108

4.2.2.2 Nutrient distribution in the

foliage................... 111

4.2.2.3 Nutrient uptake and distribution at maturity.................. 111

4.2.2.4 Nature of $P \times Z n$ interaction..... 122

4.2.3 $\mathrm{P} \times \mathrm{Zn}$ interaction in beans........... 126

4.2 .3 .1 yields.................... 126

4.2.3.2 Zinc concentration and uptake in bean plants................. 126

4.2.3.3 Phosphorus concentration and uptake in bean $\mathrm{plants... \ldots \ldots \ldots \ldots \ldots .......138}$

4.2.3.4 Zinc and $P$ derived from applied source.................... 146

4.2.4 Effectiveness of Zn fertilizers......... 151

4.3 Distribution of Native and Applied Zinc........ 155

4.3 .1 Distribution of native $2 n \ldots \ldots \ldots \ldots \ldots \ldots \ldots$

4.3.2 Distribution of applied $\mathrm{Zn} \ldots \ldots \ldots \ldots \ldots \ldots 157$ 


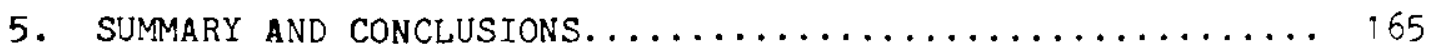

6. BIBLIOGRAPHY ......................... 173

APPENDIX .............................. 198 
2.1 Sensitivity of crops to low levels of available

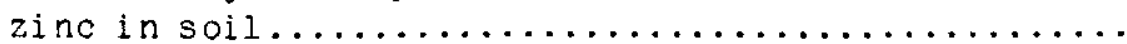

3.1 Soil characteristics of experimental sites......... 48

3.2 Physical and chemical characteristics of the soil

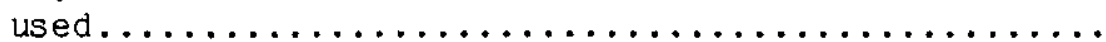

3.3 Chemical composition of zine-lignosul phonates prepared from low-yield ammoni um based ( $Z n L Y$ ), and hi gh-yield sodium based (ZnHY) lignosul phonates.....

3.4 Physical and chemical characteristics of the soils

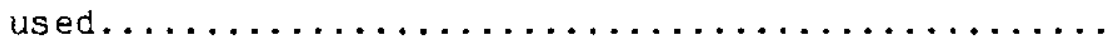

4.1.1 Statistical summary for DTPA-extractable mi cro-

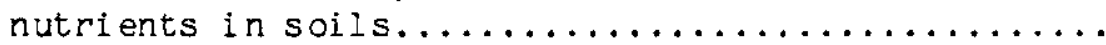

4.1.2 Correlation coefficients among micronutrients and organic carbon, bulk density and depth of soil horizon sampled.

4.1.3 Number of soil samples to give mean DTPA-extractable micronutrient value with specified confidence limits.

4.1.4 Number of constant depth $(0-15 \mathrm{~cm})$ soil sampies from the cultivated field to give mean values of DTPA-extractable micronutrients with specified

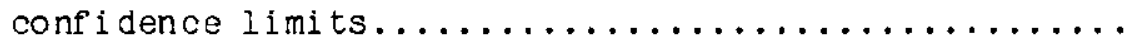

4.1.5 Statistical summary for the "total" DTPA-extractable

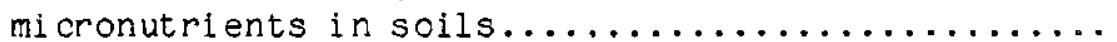

4.1.6 Statistical summary for DTPA-extractable soil $\mathrm{Zn}$ levels and tissue $\mathrm{Zn}$ concentration at FEEKES 10

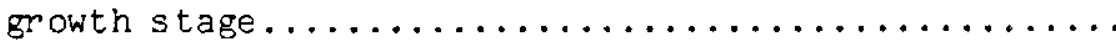

4.1.7 Number of samples to give mean DTPA-extractable soil $Z n$ levels and tissue $Z n$ concentration at FEEKES 10 growth stage with specified confidence limits.......

4.1.8 Correlation coefficients between DTPA-extractable $\mathrm{Zn}$ and selected soil and plant parameters............ 90

4.2.1 Distribution of DTPA-extractable $\mathrm{Zn}$ levels........ 94

4.2.2 Crop yield responses to Zn fertilization on soils in

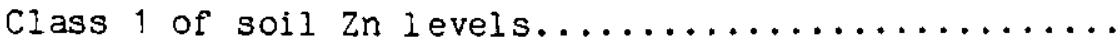


4.2.3 Crop yield responses to Zn fertilization cbtained on soil in Class 2 of soil $\mathrm{Zn}$ levels............. 97

4.2.4 Crop yield responses to $\mathrm{Zn}$ fertilization obtained on

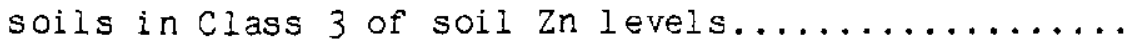

4.2.5 Sumary of $\mathrm{Zn}$ field experiments in Saskatchewan

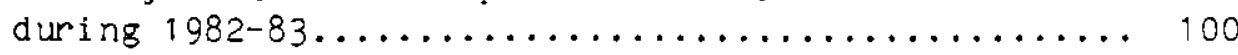

4.2.6 Concentration of $\mathrm{Zn}$ in plant tissue of crops grown on soils in Class 1 of soil $\mathrm{zn}$ levels............ 102

4.2.7 Concentration of $\mathrm{Zn}$ in plant tissue of crops grown

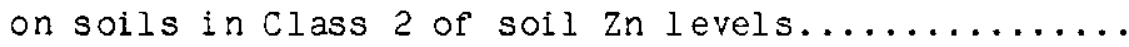

4.2.8 Concentration of $\mathrm{Zn}$ in plant tissue of crops grown on soils in Class 3 of soil $\mathrm{zn}$ levels............ 104

4.2.9 Summary of plant tissue $\mathrm{Zn}$ levels in various crops... 105

4.2.10 DTPA-extractable $Z$ n levels in soil samples $(0-15 \mathrm{~cm}) .106$

4.2.11 Crop yield responses to residual $\mathrm{Zn}$ in 1984 following

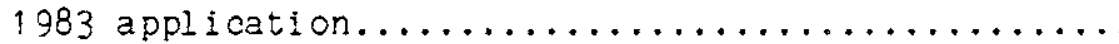

4.2.12 Effect of $P$ applied in 1979 and $Z n$ applied in 1984 on

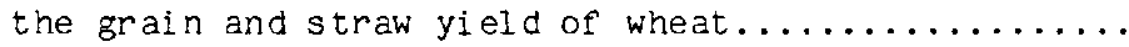

4.2.13 Mean squares from the analysis of variance for grain and straw yield of wheat.................... 110

4.2.14 Effect of $P$ applied in 1979 and soil applied $Z n$ in 1984 on tissue $\mathrm{Zn}$ and $\mathrm{P}$ concentration of wheat at FEEKES- 6 and FEEKES- 10 growth stages.

4.2.15 Mean squares from the analysis of variance for tissue $Z n$ and $P$ concentration of wheat.

4.2.16 Ef fect of $P$ applied in 1979 and foliariy applied $\mathrm{Zn}$ chelate in 1984 on tissue Zn concentration at FEEKES

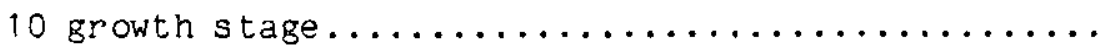

4.2.17 Effect of $P$ applied in 1979 and $Z n-s u l f a t e$ applied in 1984 on $\mathrm{Zn}$ and $\mathrm{P}$ concentration and uptake of

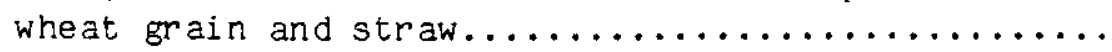

4.2.18 Ef fect of $P$ applied in 1979 and $Z n$-chelate applied in 1984 on $\mathrm{Zn}$ and $\mathrm{P}$ concentration and uptake of

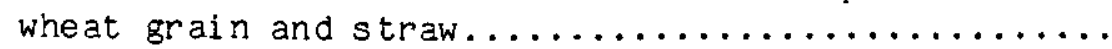

4.2.19 Effect of $P$ applied in 1979 and $Z$ n-chelate applied on foliage in 1984 on $\mathrm{Zn}$ and $\mathrm{P}$ concentration and

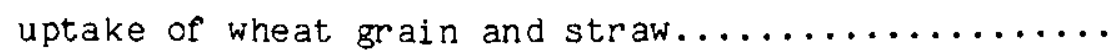


4.2.20 Mean squares from the analysis of variance for $\mathrm{Zn}$ and $P$ concentration and uptake of wheat grain and

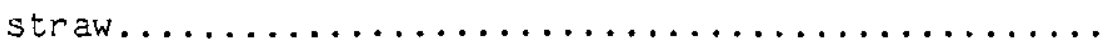

4.2.21 Mean squares from the analysis of variance for $\mathrm{Zn}$ and $P$ concentration and uptake of wheat grain and

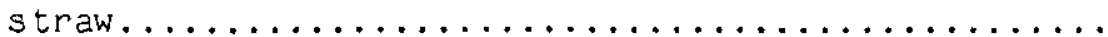

4.2.22 Mean squares from the analysis of variance for $\mathrm{Zn}$ and $P$ concentration and uptake of wheat grain and

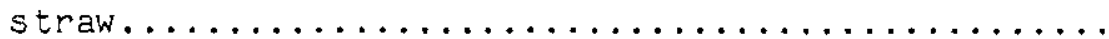

4.2.23 Effect of $P$ and $Z n$ application on the yield of

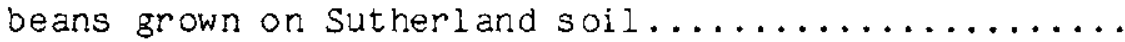

4.2.24 Effect of $\mathrm{P}$ and $\mathrm{Zn}$ application on the yield of beans grown on Carrot River soil ............... 128

4.2.25 Effect of $P$ and $Z n$ application on the yield of beans grown on Meota soil.................. 129

4.2.26 Effect of $P$ and $Z n$ application on the $Z n$ concentration of beans grown on Sutherland soil.........130

4.2.27 Effect of $P$ and $Z n$ application on the $Z n$ concentration of beans grown on Carrot River soil ........ 131

4.2.28 Effect of $P$ and $Z n$ application on the $Z n$ concentration of beans grown on Meota soil........... 132

4.2.29 Effect of $P$ and $Z n$ application on the $Z n$ uptake of beans grown on Sutherland soil............... 135

4.2.30 Effect of $P$ and $Z n$ application on the $Z n$ uptake of beans grown on Carrot River soil.............. 136

4.2.31 Effect of $P$ and $Z n$ application on the $Z n$ uptake of beans grown on Meota soil ................. 137

4.2.32 Effect of $P$ and $Z n$ application on the $P$ concentration of beans grown on Sutherland soil......... 139

4.2.33 Effect of $P$ and $Z n$ application on the $P$ concentration of beans grown on Carrot River soil........ 140

4.2.34 Effect of $P$ and $Z n$ application on the $P$ concentration of beans grown on Meota soil........... 141

4.2.35 Effect of $P$ and $Z n$ application on the $P$ uptake of beans grown on Sutherland soil. 
4.2.36 Effect of $P$ and $Z$ n application on the $P$ uptake of

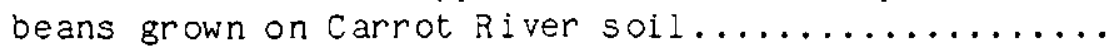

4.2.37 Effect of $P$ and $Z n$ application on the $P$ uptake of

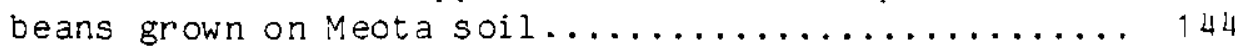

4.2.38 Zinc derived from fertilizer ( $\%$ Zndff) by beans grown on sutherland soil ................... 147

4.2.39 Zinc derived from fertilizer ( $\%$ Zndff) by beans grown on Carrot River soil ................. 148

4.2.40 Zinc derived from fertilizer (\% Zndff) by beans grown on Meota soil...................... 148

4.2.41 Phosphorus derived from fertilizer (\% Pdff) of beans at $1 / 10$ bloom stage in three soils.............. 150

4.2.42 Effect of $\mathrm{Zn}$ sources on dry matter yield (DMY), $\mathrm{Zn}$ concentration and uptake by beans and DTPA-

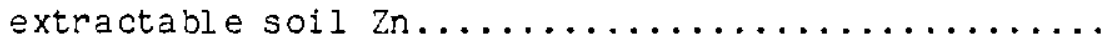

4.2.43 Effect of $\mathrm{Zn}$ rate of $\mathrm{Zn}$-sulfate $\left(\mathrm{ZnSO}_{4}\right)$ and low yield ammonium based $Z n-l i g n o s u l f o n a t e ~(Z n L Y)$ on dry matter yield (DMY), $\mathrm{Zn}$ concentration and uptake by beans and DTPA-extractable soil $\mathrm{Zn} \ldots \ldots \ldots \ldots \ldots \ldots$.

4.2.44 Recovery of applied $\mathrm{Zn}$ by DTPA in the incubation

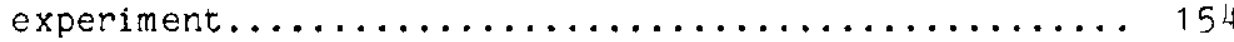

4.3.1 Distribution of native $\mathrm{Zn}$ in different fractions.... 156

4.3.2 Distribution of added $\mathrm{zn}$ in different fractions

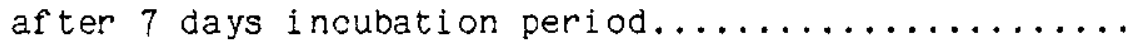

4.3.3 The effect of time and $P$ on the distribution of added $\mathrm{Zn}$ in Carrot River soil............... 162

4.3.4 The effect of time and $P$ on the distribution of

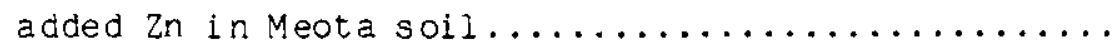

4.3.5 The effect of time and $P$ on the distribution of added $\mathrm{Zn}$ in Sutherland soil 


\section{LIST OF FIGURES}

Figure

Page

2.1 The hydrolysis species of $\mathrm{Zn}^{2+}$ in equilibrium with

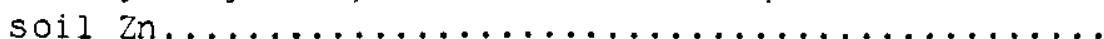

2.2 Langmuirian adsorption of zinc by three calcareous Arizona soils.......................... 17

2.3 Langmuir isotherm for $\mathrm{Zn}$ adsorption by Decatur $\mathrm{A}$

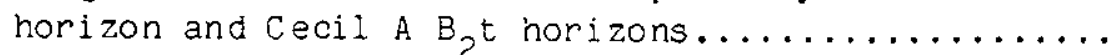

3.1 Relative locations and elevations of the four

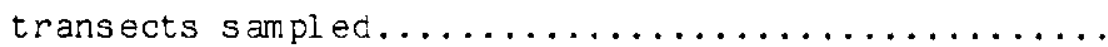

3.2 A linear semi variogram model................. 44

3.3 Distribution of micronutrient sampling sites $(1982-83)$

3.4 Fractionation procedure for native and applied Zn...

4.1 Distribution of DTPA-extractable zinc in the $A$ and $B$ horizons of a $46 \mathrm{~m}$ transect of soils sampled every meter; (a) native prairie, (b) cultivated field.....

4.2 Distribution of DTPA-extractable manganese in the A and $B$ horizons of a $46 \mathrm{~m}$ transect of soils sampled every meter; (a) native prairie, (b) cultivated field.

4.3 Distribution of DTPA-extractable iron in the $A$ and $B$ horizons of a $46 \mathrm{~m}$ transect of soils sampled every meter; (a) native prairie, (b) cultivated field.....

4. 4 Distribution of DTPA-extractable copper in the $A$ and $B$ horizons of a $46 \mathrm{~m}$ transect of soils sampled every meter; (a) native prairie, (b) cultivated field.....

4.5 Experimental (black dots) and fitted models (solid lines) semi variograms for soil $\mathrm{Zn}$; (a) transect A,

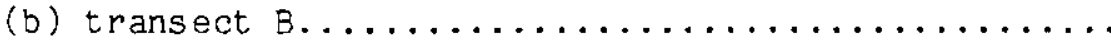

4.6 Experimental (black dots) and fitted model (solid I ine) semi variogram for soil. Zn of transect C......

4.7 Experimental (black dots) and fitted model (solid I ine) semi variograms for plant $\mathrm{Zn}$; (a) transect $\mathrm{A}$, (b) transect $B$

4.8 Experimental (black dots) and fitted model (solid line) semivariogram for plant $\mathrm{Zn}$ of transect $\mathrm{C} \ldots \ldots$. 
4.9 Experimental (black dots) and fitted model (solid $I$ ines) cross-semivariograms between soil $\mathrm{Zn}$ and organic carbon; (a) transect A, (b) transect B..... 92

4.10 Experimental (black dots) and fitted model (solid line) cross-semi variogram between soil $\mathrm{Zn}$ and or ganic carbon for transect $c \ldots \ldots \ldots \ldots \ldots \ldots \ldots$

4.11 Relationship between mycorrhizal infection of wheat

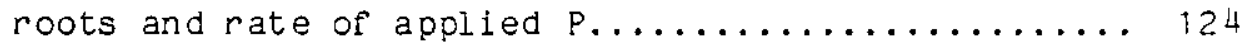

4.12 Relationship between $\mathrm{Zn}$ levels in wheat plant tissue at FEEKES 10 and grain and straw and mycorrhizal

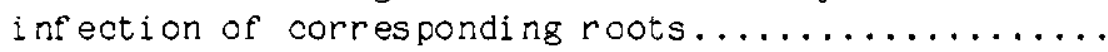




\section{INTRODUCTION}

Early assessment of the micronutrient fertility status of Saskatchewan soils showed that most of the province's soils were adequately supplied with micronutrients for cereal crops (Stewart 1969). However, recent analysis of soil and plant samples submitted to the Saskatchewan Soil Testing Laboratory (SSTL) suggested that micronutrients could be a yield limiting factor (Tomasiewioz and Stewart, 1982). Thus, research has accelerated in the last few years and an attempt has been made to either verify or reject the hypothesis that there is no need for micronutrient fertilization of Saskatchewan soils. As a result of this, Cu deficiencies in some mineral soils and $\mathrm{Cu}$ and Mn deficiencies in organic soils have already been uncovered (Karamanos et al., 1984a, 1985, 1986; Kruger et al., 1985).

Zinc deficiency is one of the most common micronutrient deficiencies in agricultural crops on a global basis. It is becoming increasingly significant affecting a wide variety of plants and soils. The susceptibility of plants to $\mathrm{Zn}$ deficiency varies greatly among plant species and even among cultivars (Viets et al., 1954a; Brown et al., 1972). Zinc deficiency has been observed extensively in the United States, Australia and many tropical countries (Thorne, 1957; Lindsay, 1972; Kanwar and Youngdahl, 1985). Low Zn levels have also been shown to occur in the soils of several European countries (Aubert and Pinta, 1977). The zn nutritional problem for fruit trees in Canada has long been delineated in the provinces of ontario and British Columbia (Woodbridge, 1954; Heeney et al., 1964) and has now been confirmed in isolated cases for agricultural crops in prairie 
soils (Crepin, 1983; Loewen-Rudgers et al., 1983).

In Saskatchewan, Stewart and Tahir (1971) found that DTPAextractable $\mathrm{Zn}$ levels in soil were highly correlated with plant $\mathrm{Zn}$ concentrations especially at the tillering stage. Multiple regression analysis relating available $\mathrm{Zn}$ to various soil chemical properties led to the conclusion that the $\mathrm{Zn}$ status of a soil could be predicted from the information that can be obtained from Saskatchewan soil survey reports. In preliminary soil test calibration work, Edin et al.

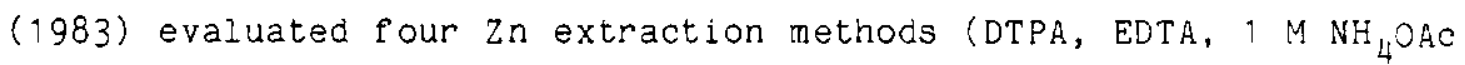
and $0.1 \mathrm{M} \mathrm{HCl}$ ) for their ability to separate responding from nonresponding soils in a growth chamber experiment using alfalfa as a indicator plant. The DTPA test (Lindsay and Norvell, 1978) was found to be most suitable as an index of $\mathrm{Zn}$ deficient soils with a critical value of $0.55 \mathrm{mg} \mathrm{kg}^{-1}$ of soil. This was slightly higher than the critical value of $0.5 \mathrm{mg} \mathrm{Zn} \mathrm{kg}^{-1}$ of soil adopted by the Saskatchewan Soil Testing Laboratory (SSTL). The need of verification of these values as well as of $\mathrm{Zn}$ fertilization under field conditions is of primary agronomic and economic importance.

The plant availability of $\mathrm{Zn}$ is conditioned by a number of soil and environmental factors: pH, adsorption on surfaces of clay, organic matter, carbonate, and oxide minerals, complexation by organic matter, interaction with other nutrients, and climatic conditions (Lindsay, 1972; Olsen, 1972; Stevenson and Ardakani, 1972; Shuman, 1980). Factors such as high pH and high clay, organic matter, oxide and carbonate contents favour $\mathrm{Zn}$ fixation and also affect the distribution of $\mathrm{Zn}$ among different forms. Separation of various forms of $\mathrm{Zn}$ in soil has been useful in studying the retention and release of 
Zn by the soil to the plant. Zino associated with different soil fractions varies in plant availability. The zinc present in watersoluble, exchangeable, and adsorbed fractions is readily available, whereas $\mathrm{Zn}$ associated with primary and secondary minerals is relatively unavailable to plants (Viets, 1962). In determining the distribution of $\mathrm{Zn}$, one can find better extractants that remove $\mathrm{Zn}$ in proportion to that removed by plant. The dynamics of $\mathrm{zn}$ transformations from one chemical form to another, in response to changing soil conditions, can be answered by studying the distribution of $\mathrm{zn}$ in various forms.

There are widespread reports that high phosphorus availability in soil induces $2 n$ deficiency. This interaction occurs mainly when plants are grown in soil or culture media low in available zn (Olsen, 1972). Many of the results have been confusing because the accentuated symptoms of $Z n$ deficiency were not always accompanied by reduction in $\mathrm{Zn}$ concentration in plant tops (OIsen, 1972). In Saskatchewan, Wagar et al. (1986) studied the effect of single broadcast fertilizer $P$ applications on wheat yield and nutrient uptake in a Sutherland soil (Dark Brown Chernozemic) over a period of six years. They observed that high $P$ rates significantly reduced $Z n$ levels in plant tissue and suspected that $\mathrm{Zn}$ disorder could be a yield Iimiting factor in their study.

In the past two years, a number of field experiments on micronutrient requirements of various crops have been conducted in different parts of Saskatchewan. In a number of cases, no yield response were obtained in spite of soil test values indicating deficient levels (Karamanos et al., 1984b). Although this jehavior 
may be attributed to several factors, spatial variation of micronutrients appeared to be the most likely one. The heterogeneity of soil fertility has been stressed by Peck and Melsted (1967), who have further suggested that sampling plans should be designed in such a manner as to reveal variation within each field. This is essential in the proper interpretation of a soil test, especially since recommendation of nutrient application relies on the nutrient value determined for a composite sample.

The general objectives of this research were, therefore:

(i) to study the spatial variability of $\mathrm{Zn}$ in Saskatchewan soils of both uniform and undulating topographies,

(ii) to examine the importance of $\mathrm{Zn}$ to crop nutrition and production of common crops in Saskatchewan, and

(iii) to understand the transformations of native and added $\mathrm{Zn}$ in soils and their distribution among different soil zn fractions in relation to plant availability. 


\section{LITERATURE REVIEW}

\subsection{Zinc in Plant Physiology}

Zinc is one of the more dissociated metal ions in xylem fluid but it can sometimes be bound to organic complexes (Tiffin, 1972). The form in which $\mathrm{Zn}$ is translocated from roots to the upper plant parts is not well understood. Electrophoretic evidence indicates that Zn in xylem fluid is not bound to stable ligands. Zinc is slightly cathodic and is not translocated as citrate since $\mathrm{Zn}$ citrate compiexes are anodic (Tiffin, 1972).

The $\mathrm{Zn}$ requirement of plants is generally small but plant species differ in their $\mathrm{Zn}$ requirements (Lindsay, 1972) and in their sensitivity to $\mathrm{zn}$ deficiency (Viets et al., 1954a). Carroll and Loneragan (1969) obtained maximum or near maximum yield of eight different plant species in flowing water culture experiments with $\mathrm{Zn}$ concentrations in the range of $0.01 \times 10^{-6} \mathrm{M}$ to $2.5 \times 10^{-6} \mathrm{M}$. Maximum yield of plants was obtained with an uptake of between 10-30 ng atom of $\mathrm{Zn}$ per gram of fresh root material per day.

It is now generally accepted that $z$ n uptake is metabolically controlled (Moore, 1972). Schmid et al. (1965) and Bowen (1969) using barley roots and sugarcane leaf tissue concluded that metabolic $\mathrm{Zn}$ uptake by plants was characterized by a steady state rate. Zinc uptake was considerably reduced by low temperature and by metabolic inhibitors.

Essential functions of $\mathrm{Zn}$ in plants have been identified and characterized. Zinc deficiency symptoms show wide variations in different plant species. The common symptom of $Z n$ deficiency are 
chlorosis in the interveinal area of the leaf. These are paie green, yellow or even white followed by the appearance of brown necrotic spots in young leaves by stunting and delayed vegetative and reproductive development (Mengel and Kirkby, 1982).

How Zn deficiency explicitiy influences these symptoms is not well understood. Some $\mathrm{Zn}$ enzymes which perform essential functions in plants have been identified and characterized. Zinc is an essential component of cellular membranes and is also present in a number of metalloenzymes, particulariy in carobnic anhydrase, various dehydrogenases, proteinases and and peptidases (Vallee and Wacker, 1970; Jacobson et al., 1975). One of the effects of $\mathrm{Zn}$ deficiency may well be related to the reduction of net photosynthesis. Onki (1978) found reduced photosynthesis and carbonic anhydrase activity in $\mathrm{Zn}$ deficient soybean plants. Seethambaram and Das (1985) observed a decline in net photosynthetic rate and $\mathrm{CO}_{2}$ fixation with $\mathrm{Zn}$ deficiency in oryza sativa L. and Pennisetum american L. They attributed this to lowered levels of carbonic anhydrase, energy and reducing power in the former, but to lowered energy and reducing power alone in the latter. Clearly carbonic anhydrase, a chloroplast enzyme, catalyzes the reaction between $\mathrm{CO}_{2}$ and $\mathrm{H}_{2} \mathrm{O}$ to form $\mathrm{H}^{+}+\mathrm{HCO}_{3}{ }^{-}$in photosynthesis (Jacobson et al., 1975).

The levels of carbohydrates in the plant are also affected. Seethambaram and Das (1985) reported lower levels of reducing sugar in leek (Pennisetum american L.) plants presumably due to the effect of Zn on photosynthesis.

Zinc is closely involved in the $\mathrm{N}$ metabolism of the plants. Price et al. (1972), in a review article, cited a number of references 
indicating that the possible causal event in the case of In deficiency is a sharp decrease in the concentrations of RNA and ribosome in cells. This reduction in RNA synthesis leads to an inhibition of protein formation while glucose, non-protein $\mathrm{N}$ and DNA are relatively increased. Zinc is also required in the synthesis of tryptophan. Under $\mathrm{Zn}$ deficiency, concentration of indoleacetic acid is decreased possibly due to inhibited synthesis of tryptophan (Salami and Kenefick, 1970). In sharp contrast to these results, Takaki and Kushizaki (1970) found higher levels of tryptophan in $\mathrm{Zn}$ deficient maize plants and concluded that $\mathrm{Zn}$ is required in the synthesis of indoleacetic acid from tryptophan. However, a causal relationship between $\mathrm{Zn}$, tryptophan and indoleacetic acid has yet to be established (Price, 1970).

According to Jyung et al. (1975) Zn has a possible role in plant metabolic processes associated with starch formation. These authors compared the behaviour of two cultivars of navy bean (Phaseolus vulgaris), one susceptible to $\mathrm{Zn}$ deficiency and the other not, grown under $z$ n deficiency conditions. The starch content, the activity of the starch synthetase enzyme, and the number of starch grains of the susceptible cultivar were all more depressed compared to the non-susceptible one. Further, a very close inverse relationship between the degree of $2 n$ deficiency and starch formation was established. Whether this effect on starch formation is a primary result of $Z$ n deficiency still remains an open question.

Zinc deficiency may influence $\mathrm{N}_{2}$ fixation directiy by affecting nodule nutrition and indirectly by afecting host nutrition (Demeterio et al., 1972). Rhoden and Allen (1982) found a significant increase 
in $\mathrm{N}_{2}$ fixation with appication of $\mathrm{Zn}$. Rate of $\mathrm{N}_{2}$ fixation was highly correlated with nodule number. They argued that, since both nodulation and $\mathrm{N}_{2}$ fixation peaked at the same rate of $\mathrm{Zn}$, increased rate of $\mathrm{N}_{2}$ fixation could have been directly associated with the increased nodulation.

\subsection{Zinc Containing Minerals and Zn Content in Soils}

The average $\mathrm{Zn}$ content of the lithosphere is $80 \mathrm{mg} \mathrm{kg}^{-1}$, whereas the $\mathrm{Zn}$ content of normal soils ranges from $10-300 \mathrm{mg} \mathrm{kg}^{-1}$ (Hodgson, 1963). The $\mathrm{zn}$ content of soils varies widely. Shuman (1980) cited a number of references reporting lower and also much higher values for total $\mathrm{zn}$ content of soils, reflecting differences in parent materials, age and type of soil, and climatic, topographic and biological conditions.

The abundance of $\mathrm{Zn}$ in the parent material is one of the major factors determining $\mathrm{Zn}$ content in soils, particularly in younger soils. Zinc in igneous rocks tends to concentrate in mafic rather than in felsic rocks because it can substitute in silicates for $\mathrm{Mg}^{2+}$ and $\mathrm{Fe}^{2+}$ and occurs in the form of small grains of sphalerite in the mafic rocks. The largest $2 n$ concentration in sedimentary rocks is found in shales where $\mathrm{Zn}$ is held in adsorbed form and in the lattice structure of clay minerals (Krauskopf, 1972). Igneous rocks such as basalt and granite contain on an average $100 \mathrm{mg} \mathrm{kg}{ }^{-1}$ and $40 \mathrm{mg} \mathrm{kg} \mathrm{kg}^{-1}$ of $\mathrm{Zn}$, respectively. Among sedimentary rocks, shale contains more $\mathrm{Zn}$ ( 95 mg $\mathrm{kg}^{-1}$ ) than either 1 imestone $\left(20 \mathrm{mg} \mathrm{kg}{ }^{-1}\right)$ or sandstone $\left(16 \mathrm{mg} \mathrm{kg}^{-1}\right)$ (Krauskopf, 1972).

Minerals of $\mathrm{Zn}$ include sphalerite ( $\mathrm{ZnS}$ ), smithsonite ( $\mathrm{ZnCO}_{3}$ ) 
and hemimorphite $\left(\mathrm{Zn}_{4}(\mathrm{OH})_{2} \mathrm{Si}_{2} \mathrm{O}_{7} \cdot \mathrm{H}_{2} \mathrm{O}\right)$. Zinc occurs chiefly as the single sulfide mineral sphalerite which indicates the metal is largely chalcophile. The $\mathrm{Zn}$ ion, with an ionic radius of $0.83 \AA$, does substitute to some extent for $\mathrm{Mg}(0.78 \mathrm{~A})$ and $\mathrm{Fe}(0.83 \mathrm{~A})$ in silicate minerals, so that it is partly lithophile as well. Zinc most commonly shows four-fold coordination in mineral structure but in some minerals it has 6-coordination with oxygen (Krauskopf, 1972).

Tiller and Pickering (1974) synthesized $2 n$ silicates in weathering environments. They formed stevensite and concluded that neither willinite nor hemimorphite are important in controling chemical reaction of $\mathrm{Zn}$ in soils. Both Krauskopf and Lindsay (1972) are of the opinion that sphalerite ( $\mathrm{ZnS}$ ) is unstable under normal oxidizing conditions. Kittrick (1976), however, suggested that $\mathrm{Zn}$ in soil solution could be controlled by $\mathrm{znS}$ if the soil was in equilibrium with atmospheric $\mathrm{H}_{2} \mathrm{~S}$, since $\mathrm{ZnS}$ is the only $\mathrm{Zn}$ mineral insoluble enough to control $\mathrm{Zn}$ at ppb levels.

Weathering of $\mathrm{Zn}$ minerals releases $\mathrm{Zn}^{2+}$ into soil solution. The $\mathrm{Zn}$ ions released may combine with anions in the soil solution to form a new solid phase as $\mathrm{Zn}$ carbonate or $\mathrm{Zn}$ hydroxide. Alternatively, $\mathrm{Zn}$ ions may be adsorbed on different soil minerals and subsequently fixed irreversibly. All the above $\mathrm{Zn}$ compounds are too soluble to account for the small concentration of $\mathrm{zn}$ found in most soil solutions (Lindsay, 1979). Adsorption and desorption by clay minerals, oxides, carbonates and organic matter are much more 1 ikely mechanisms controlling $\mathrm{Zn}$ concentration in soil solution (Brummer et al., 1983). 


\subsection{Zinc Species in Soil Solution}

The levels of $Z n$ in soil solution are very low. Hodgson et al. (1965, 1966) measured $Z n$ levels in soil solution dispiaced from 20 Colorado and four New York soils. The total $\mathrm{Zn}$ concentration averaged $<2 \mathrm{ppb}$ and $74 \mathrm{ppb}$ for the Colorado and the New York soils, respectively. They separated soil solution $\mathrm{Zn}$ into ionic and complexed form and reported that on an average $60 \%$ and $55 \%$ of the soluble $\mathrm{Zn}$ occurs presumably in soluble $\mathrm{Zn}$ organic complexes for the colorado and the New York soils, respectively.

McBride and Blasiak (1979) observed that the proportion of $\mathrm{Zn}$ complexed in solution increased as soil pH increased. At soil pH values above 6.5 , much of the $Z n$ in solution was complexed with soluble organic material. This may explain the differences between the New York and the Colorado soils as reported by Hodgson et al. (1965, 1966) since the latter had much higher average pH values than the former. Stevenson and Ardakani (1972) reviewed the micronutrient organic matter reactions and concluded that soluble 2 n organic complexes are mainly associated with amino, organic and fulvic acids, while insoluble organic complexes are derived from humic acid.

Numerous ionic and complexed ionic species including those of $\mathrm{Zn}^{2+}$ hydrolysis are found in soil solution (Lindsay, 1979). The $\mathrm{zn}$ hydrolysis species in equilibrium with soil $\mathrm{Zn}$ are depicted in Figure 2.1. The predominant species below $\mathrm{pH} 7.7$ is $\mathrm{Zn}^{2+}$, whereas above this $\mathrm{pH}, \mathrm{ZnOH}^{+}$is more prevalent. The neutral species $2 \mathrm{n}(\mathrm{OH})_{2}$ is the major species at $\mathrm{pH}$ values above 9.1 , whereas the species $2 \mathrm{n}(\mathrm{OH})_{3}^{-}$and $2 \mathrm{n}(\mathrm{OH})_{4}^{2-}$ are never major solution species in the pH range of soils. Zinc also forms complexes with chloride, phosphate, nitrate, and 


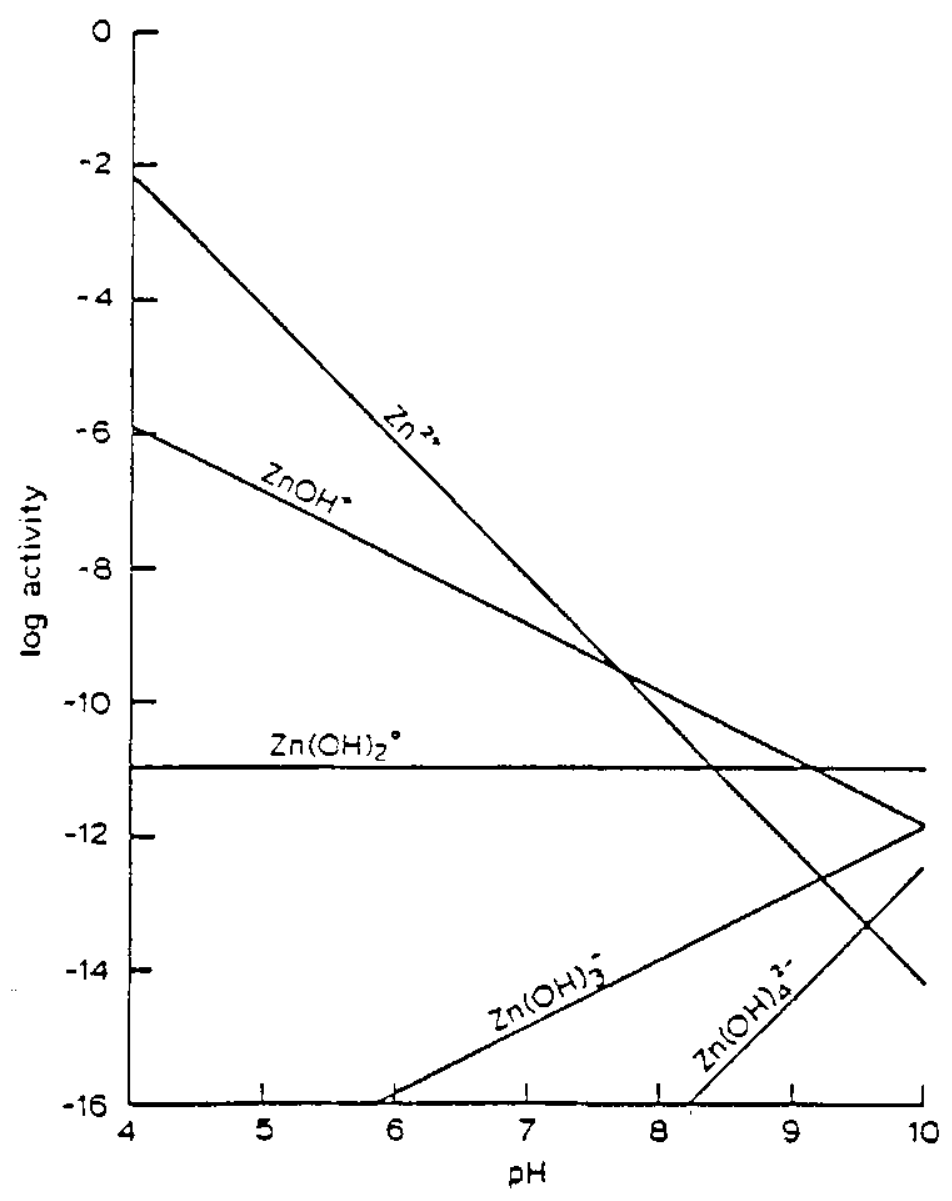

Figure 2.1 The hydrolysis species of $\mathrm{Zn}^{2+}$ in equilibrium with soil Zn (adapted from Lindsay, 1979).

sulfate. These complexes except $\mathrm{ZnSO}_{4}$ do not contribute significantly to total zine in solution. However, in neutral and calcareous soils the species $\mathrm{ZnHPO}_{4}$ may be significant depending upon $\mathrm{pH}$ and the activity of phosphate.

The solubility of zinc is highly pH dependent and decreases 100-fold for each unit increase in pH (Lindsay and Norvell, 1969). This relationship is represented by the equation:

$$
\mathrm{Zn}+\text { soil }=2 \mathrm{n} \text {-soil }+2 \mathrm{H} \text { for which } \log \mathrm{K}=-6.0
$$


which gives $\log \mathrm{Zn}=6.0-2 \mathrm{pH}$.

Zinc moves to plant roots mainly by diffusion (wilkinson et al., 1968; Elgawhary et al., 1970; Schwartz et al., 1985), where it is taken up principally in the divalent form $\left(2 \mathrm{n}^{2+}\right)$ although some monovalent forms $\left(\mathrm{ZnOH}^{+}\right.$) may also be taken up (Thorne, 1957). Halvorson and Lindsay (1977) confirmed the hypothesis that $\mathrm{Zn}$ is adsorbed by plant roots as $\mathrm{Zn}^{2+}$, since chelated $\mathrm{Zn}$ is not readily absorbed. They further observed that chelation aids in the transport and movement of Zn ions to plant roots. Both natural and synthetic chelates aid in $\mathrm{Zn}$ transport from parent material and other relatively insoluble phases to plant roots (Zunino and Martin, 1977).

\subsection{Forms and Distribution of Soil Zinc}

Separation of various forms of $\mathrm{Zn}$ in soils has been a useful tool in studying the retention of $\mathrm{Zn}$ by the soil and its release to plant. Generally $\mathrm{Zn}$ in soils has been partitioned into forms (Hodgson, 1963) or pools (Viets, 1962), primarily on the basis of ways that $\mathrm{Zn}$ is bound in soil or held against extraction by various chemical agents. These forms may be (i) water soluble (both ionic and complexed species), (ii) on exchange sites of reactive soil components, (iii) complexed with organic matter (water insoluble), (iv) occluded by soil oxides and hydroxides, and (v) entrapped in primary and secondary minerals.

The distribution of $\mathrm{Zn}$ among different forms may vary significantly depending on the soil. Several attempts have been made to separate the various physical and chemical forms of $\mathrm{Zn}$ in soils. White (1957) carried out fractionation of $\mathrm{Zn}$ in 14 Tennessee soils and 
reported that 1 to $7 \%$ of the $2 n$ was in the exchangeable form, 30 to $60 \%$ in the Fe-oxide fraction, 20 to $45 \%$ in clay fraction, and 10 to 40\% was associated with organic matter or resistant minerals. Shuman (1979) reported that 1 to $7 \%$ of the $\mathrm{Zn}$ in ten Georgia soils was in the exchangeable form and on an average $40 \%$ and $20 \%$ in the clay and Fe-oxide fractions, respectively. The percentage of $\mathrm{Zn}$ in the organic matter, sand, and silt fractions were almost similar (12\%). However, fine textured soils contained higher amounts of $\mathrm{Zn}$ associated with the clay fraction compared to coarse textured soils, in which more $\mathrm{Zn}$ was proportionately associated with the organic fraction.

Iyengar et al. (1981) studied the distribution of $\mathrm{Zn}$ among different fractions for 19 soils, which varied widely in chemical and physical properties. There was wide variation in the magnitude of $\mathrm{zn}$ fractions among these soils. On average most of the total $\mathrm{zn}$ was present in the Fe-oxide (25\%) and residual (70\%) fractions. The exchangeable (non-specifically and specifically adsorbed), organically bound and $M n-o x i d e$ bound $\mathrm{Zn}$ fractions averaged $3.7(0.4$ and 3.3$), 2.5$ and $2.0 \%$ of total $\mathrm{Zn}$, respectively.

Sedberry and Reddy (1976) found that an average of $1.7,0.9$, $2.6,4.4$ and $86.4 \%$ of the $\mathrm{zn}$ in ten Louisiana soils was in the water soluble, exchangeable, chelated, organic and residual mineral fractions, respectively. The high values for residual mineral $\mathrm{Zn}$ fraction reported for these soils was probably associated with soll oxides and hydroxides as the fractionation technique followed by the authors did not account for $\mathrm{Zn}$ associated with these fractions.

Variation in soil environments causes a redistribution of $\mathrm{Zn}$ among different fractions. Sims and Patrick (1978) found that $2 n$ was 
higher in the exchangeable and organic fractions at Iow pH and En than at high $\mathrm{pH}$ and En, whereas the amounts of $\mathrm{Zn}$ in the water soluble and Mn- and Fe-oxide fractions were greater at high pH and Eh values. More recently, Shuman and Hargrove (1985) studied the effect of tillage on the distribution of $\mathrm{Zn}$ fractions. The exchangeable fraction was the only fraction in which $Z n$ was significantly lower for conventional tillage compared to minimum tillage.

Zinc is especially sensitive to soil pH. The exchangeable fractions increases as soil pH decreases, but the specifically adsorbed and Mn-oxide Zn fraction increase with increases in soil pH (Iyengar et al., 1981). In a study with 19 soils (Iyengar et al., 1981), the organic $2 n$ fraction was found to increase as the organic matter content increased and much of the residual $\mathrm{Zn}$ was present in clay-sized minerals. Similarly, Shuman (1979) reported that residual Zn was mostly associated with the clay fraction of fine textured soils. It seems likely that exchangeable $\mathrm{zn}$ would decrease when the cation exchange capacity and clay content decrease because fewer exchange sites would be available for adsorption. However, Shuman (1985) reported an unusual increase in exchangeable $\mathrm{Zn}$ with a decrease in cation exchange capacity and silt and clay content.

Zinc in different soil fractions varies in plant availability (Viets, 1962). Iyengar et al. (1981) attempted to relate different fractions of $\mathrm{Zn}$ to plant availability. Zinc uptake varied directly with exchangeable $\mathrm{Zn}$ and organically-bound $\mathrm{Zn}$ and inversely with oxide-bound $\mathrm{zn}$. One interesting finding of their study was a highly significant positive correlation between the residual $\mathrm{Zn}$ form and $\mathrm{Zn}$ plant uptake. In contrast to this, Iyengar and Deb (1977) reported 
that the residual mineral $Z n$ fraction does not contribute significantly to plant uptake and that complexed, water soluble, exchangeable and organically bound $\mathrm{Zn}$ were the most important fractions contributing to plant uptake.

Stanton and Burger (1967) reported that hydrous Ee-oxides, in the presence of phosphate ions, fixed $\mathrm{Zn}$ in a plant unavailable form. In the absence of phosphate ions, however, the oxides had a strong affinity for $Z n$, but $Z n$ fixation in unavalable forms did not occur. Goethite, on the other hand, fixed $\mathrm{zn}$ against plant uptake irrespective of the absence or presence of phosphate ions. In sharp contrast to these results, Marinko and Igue (1972) found that treatinent of volcanic ash soils and oxisols with large quantities of $P$ fertilizer led to neither enhancement of $\mathrm{Zn}$ adsorption nor depression in $\mathrm{Zn}$ uptake by corn plants grown on these soils. Cavallaro (1982) observed lowered $\mathrm{Zn}$ adsorption by soil clays when clay surfaces were saturated with $P$.

In comparing these studies, it is important to consider the quantities of adsorbed $\mathrm{Zn}$ and phosphate relative to the surface capacity for adsorption, as well as the ionic medium, which the metal ions were adsorbed from. Phosphate adsorption increases the negative charges of soil clays containing oxides as demonstrated by electrophoretic mobility measurements (Cavallaro, 1982). Hence, enhanced metal ion adsorption by electrostatic attraction might be expected. However, specific adsorption of $\mathrm{Zn}$ could simultaneously be reduced because of the occupation of fixation sites by phosphate. The actual mechanism still remains unknown. 


\subsection{Zinc Adsorption by Soil and Inorganic Constituents \\ 2.5.1 Whole soils}

Adsorption of $\mathrm{Zn}$ by soils has been the subject of research by several investigators. In general, $\mathrm{Zn}$ adsorption is found to be pH-dependent and related to soil cation exchange capacity. Sharpless et al. (1969) found that $75 \%$ of the added $\mathrm{Zn}$ adsorbed at a one minute reacton period was accounted for by the cation excinange capacity. In some soils, however, $2 / 3$ of the exchangeable $\mathrm{Zn}$ became fixed in non-exchangeable forms after a certain period. According to Kalyanasundaram and Mehta (1970), the availability of applied $2 n$ varied inversely to the proportion of finer fractions of the soil. Fixation was high ( $57 \%$ ) in a clayey soil, medium (44\%) in a mediumtextured soil, and low (35\%) in a light-textured soil.

Adsorption isotherms have been used for many years to describe the nature of various types of adsorption phenomena. An adsorption isotherm describes the amount of solute adsorbed by an adsorbent as a function of the equilibrium concentration of the solute. The quantity of ion adsorbed has generally been found to be dependent, within limits, on the concentration of ion in solution. Despite some limitations, these adsorption isotherms can give good qualitative informaton upon which certain conclusions can be based (Shuman, 1975).

Zinc adsorption often follows the Langmuir model, which can be used to obtain estimates of sorption maxima (capacity) and bonding energy for different soils. Udo et al. (1970) found that $\mathrm{Zn}$ adsorption at low concentration in calcareous soils was described by the Langmuir adsorption equation (Fig. 2.2). The calculated Langmuir adsorption maxima were related to the carbonate and organic matter 


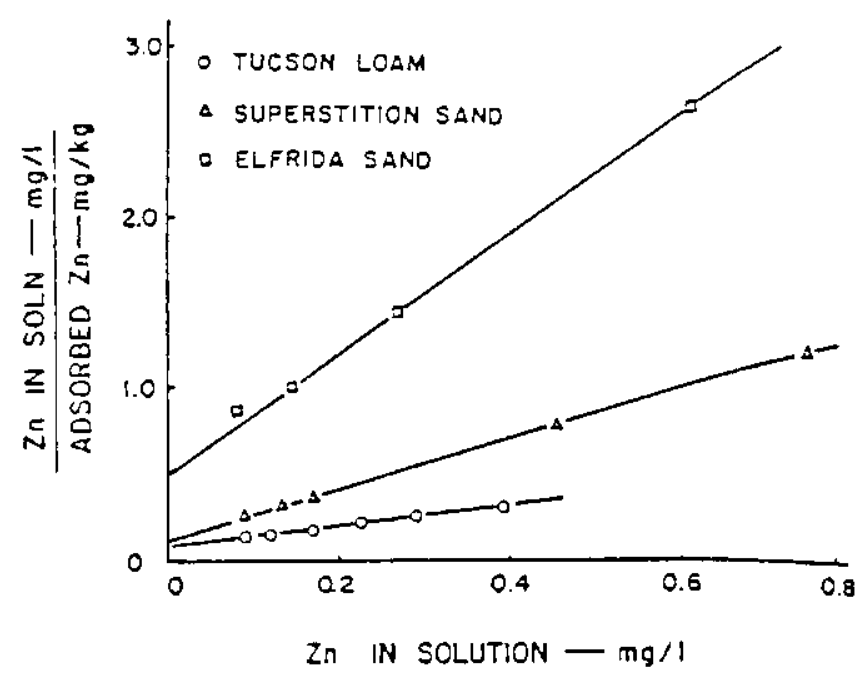

Figure 2.2 Langmuirian adsorption of zinc by three calcareous Arizona soils (adapted from Udo et al., 1970).

contents of the soils. When the added $\mathrm{Zn}$ exceeded the adsorption maxima, the $\mathrm{Zn}$ concentration at soil $\mathrm{pH}$ above 7.5 appeared to be governed by the solubility of $z$ n hydroxides or carbonates. However, this was not a factor in most soils.

The objection to precipitation as a mechanism in controlling the concentration of $\mathrm{Zn}$ in soil has been based on the fact that most of the preciptitates considered, except $\mathrm{Zn}$ suzfide (znS), are too soluble in the soil solution (Lindsay, 1979). Brummer et al. (1983) reported that concentration of $\mathrm{Zn}$ in soils at $\mathrm{pH}$ values below 7 are determined exclusively by adsorption-desorption reactions. Even at pH values above 7 , the formation of other $Z n$ compounds is unlikely in most soils because additions of large amounts of $\mathrm{Zn}$ are required to ensure saturation of the adsorption sites of different soil components before the $\mathrm{Zn}$ concentration in the soil solution can increase 
sufficiently to bring about the precipitation of a definite compound. Shuman (1975) studied the adsorption of $\mathrm{Zn}$ on four soils of varying texture. He found that $\mathrm{Zn}$ adsorption conformed to the Langmuir isotherm and that there were two Iinear portions on the curve (Fig. 2.3). The adsorption sites for the lower Iinear portion had very high bonding energy coefficients and low adsorptive capacities compared with the adsorption sites of the upper linear portion corresponding to higher $\mathrm{zn}$ concentration. Soils high in clay or organic matter had higher adsorption capacities and higher bonding energy for $\mathrm{Zn}$ than sandy soils low in organic matter. Low pH reduced Zn adsorption more for sandy soils than for those high in colloidal material.
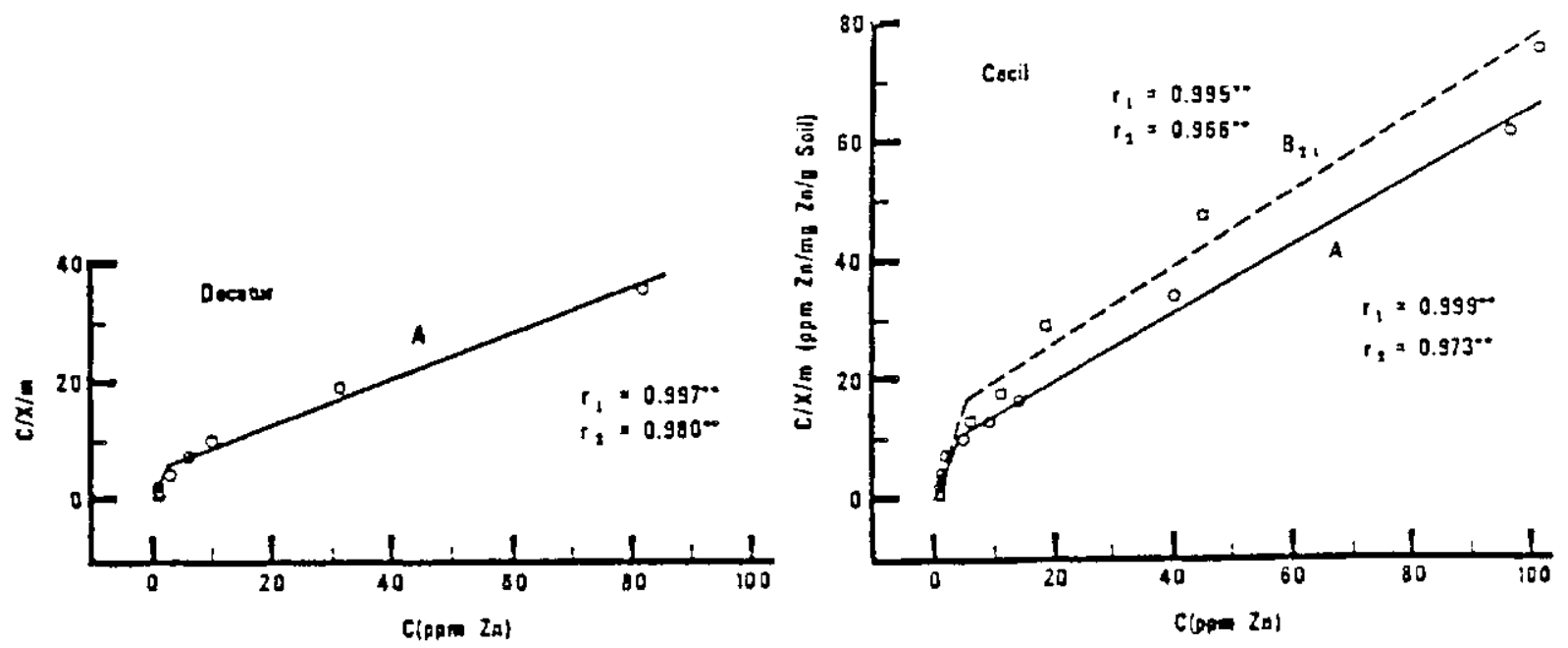

Eigure 2.3 Langmuir isotherm for $\mathrm{Zn}$ adsorption by Decatur A horizon and Cecil $\mathrm{A} \mathrm{B}_{2}$ t horizons (adapted from Shuman, 1975).

Kuo and Mikkelson (1979) reported that at extremely low $\mathrm{Zn}$ concentration, $\mathrm{Zn}$ sorption by two alkaline soils could be described by 
either Langmuir or Freundlich sorption isotherms. However, at higher Zn concentraton only a Freundich equation could describe the sorption. Zine sorption by four different California soils conformed only to the Freundlich equation (Kurdi and Doner, 1983).

Harter (1983) reported that differences among soils in the amounts of $\mathrm{Zn}$ sorbed at any given $\mathrm{Zn}$ concentration did not directly correspond with soil cation exchange capacity. One would expect to obtain such results if the amounts of sorbed $z$ n were more affected by final pH than by soil cation exchange capacity. As noted by Kurdi and Doner (1983), Zn sorption differences among the soils were more related to equilibrium $\mathrm{pH}$ than to cation exchange capacity. Soil $\mathrm{pH}$ has a strong effect on $\mathrm{Zn}$ adsorption (MCBride and Blasiak, 1979). The minimal $\mathrm{Zn}$ concentration in solution occurred between $\mathrm{pH} 7$ and 8 . Concentration of $\mathrm{Zn}$ in solution decreased 30-fold for every unit of $\mathrm{pH}$ increase in the $\mathrm{pH}$ range 5 to 7 .

\subsubsection{Layer silicates}

Soil clays play an important role in the adsorption of $\mathrm{Zn}$ and this adsorption is controlled by cation exchange capacity and $\mathrm{pH}$ (E1lis and Knezek, 1972). Nelson and Melsted (1955) found that 50-70\% of the adsorbed $\mathrm{Zn}$ is replaced by neutral salts and that an additional 15-20\% can be extracted by acid. Some of the adsorbed $\mathrm{zn}$ cannot be replaced by acid or salt solution. It is considered that this portion of $\mathrm{Zn}$ is incorporated into the lattice structure, since the ionic radius is similar to that of $\mathrm{Mg}$ in the octahedral lattice. Reddy and Perkins (1974) studied the fixation of $\mathrm{Zn}$ by bentonite, illite and kaolinite and found that kaolinite clay fixes less $2 n$ than either 
bentonite or illite and that fixed $\mathrm{Zn}$ was not substituted for lattice ions since $X$-ray and DTA (differential thermal analysis) did not reveal mineralogical changes. Although $2 n$ fixation has been attributed to lattice substitution (Elgabaly, 1950), clay adsorption of $\mathrm{Zn}$ without fixation is most likely an exchange process. DeMumbrum and Jackson (1956a) and Bingham et al. (1964) observed that montmorillonite, especially at neutral or alkaline pH, adsorbed $\mathrm{Zn}$ in excess of the cation exchange capacity. This phenomenon may be explained by two mechanisms, namely, adsorption of $\mathrm{Zn}$ in hydrolyzed forms or precipitation of $\mathrm{Zn}(\mathrm{OH})_{2}$. Brummer et al. (1983) reported that the adsorption capacity for specifically adsorbed Zn by the following components increased in the order of $\mathrm{CaCO}_{3}<$ bentonite < humic acid < amorphous Fe and Al-oxide, thus limiting the possibility of reactions.

DeMumbrum and Jackson (1956b), using inf rared techniques to study the reaction mechanism of $\mathrm{Zn}$ with layer silicates and peat, found that $\mathrm{Zn}$ saturation decreased the intensity of the $2.8 \mu$ infrared absorption band of the hydroxyl ions in montmorilionite, vermiculite, and kaolinite, indicating a reaction or bonding with the octahedral $\mathrm{OH}$ in layer silicates. This bond could be visualized as a $\mathrm{Zn}-0-\mathrm{Al}$ or $\mathrm{OH}$

Zn-0-Al in position, where access by the $\mathrm{Zn}$ ions is possible because of silica net openings, crysta? defects or position at edges. These data, together with the observation by Hodgson (1963) that a large part of $\mathrm{Zn}$ adsorbed could be replaced by non-destructive dilute acid extraction, suggests that most of the specific adsorption occurs on exposed-OH groups and not by substitution into octahedral layer. 
The dependence of $\mathrm{Zn}$ adsorption on $\mathrm{pH}$ is thought to be due to the competition effect of the $\mathrm{H}^{+}$ion and to the change of cation exchange capacity with pH. Abd-Elfattah and Wada (1981) determined the selective adsorption of $Z$ n by different cation exchange material to be: Fe oxide, halloysite > kaolinite > humus > montmorillonite. Exchange between $\mathrm{Ca}^{2+}$ and $\mathrm{Zn}^{2+}$ and solubility product $\left[\mathrm{Zn}^{2+}\right]\left[\mathrm{OH}^{-}\right]^{2}$ indicates that $\mathrm{Zn}$ is not precipitated as hydroxide but is adsorbed on cation exchange sites. Differences in specific $z$ n adsorption on different cation exchange materials is related to the cation exchange sites developed at $\mathrm{pH}$ values higher than 6.0 due to ionization of surface $\mathrm{OH}$ and $\mathrm{COOH}$ groups.

Farrah and Pickering (1977) found that $\mathrm{Zn}$ adsorption on kaolinite, illite, and montmorillonite varied with clay, pH, concentration of competing ions and nature of ligands present. Some ligands that form complexes with metal ions decrease adsorption by decreasing the concentration of adsorbing species-while other increase adsorption. Removal of iron oxides increased the capacity of clays to adsorb $\mathrm{Zn}$ in more instances than it decreased it and the adsorptive capacity was directly related to the cation exchange capacity values for clays (Shuman, 1976).

\subsubsection{0xides and hydroxides}

Hydrous oxides of $\mathrm{Fe}$ and Al can be just as important as clay minerals in $\mathrm{Zn}$ adsorption in soils. The oxides are found either free in the soil or as coating on clay minerals (Thomas and Swoboda, 1963). The ubiquitous nature of the oxides in soil makes them more important to the retention and release of $\mathrm{Zn}$ in relation to plant availability. 
Jenne (1968) has suggested that in very many situations, the levels of Zn in natural waters, including the soil solution, is controlled by adsorption on the surfaces of oxides.

Shuman (1977) equilibrated $\mathrm{Zn}$ solution with both fresh and aged Fe and Al oxides to measure $\mathrm{Zn}$ adsorption. Fresh $\mathrm{Fe}$ and $\mathrm{Al}$ oxide gels adsorbed ten times as much $\mathrm{Zn}$ as aged gels, corresponding to a tenfold difference in both cation exchange capacity and surface areas.

One of the most important properties of simple oxides is that they show a particularly strong tendency to adsorb $\mathrm{Zn}$, even when the oxide surface has a net positive charge. Zine adsorption was found to occur at $\mathrm{pH}$ values well below the isoelectric point of the oxides when the surfaces were positive and the $\mathrm{Zn}$ in a cationic form (Kinniburgh et al., 1976; Bolland et al., 1977).

Zinc can be adsorbed specifically and non-specifically on the crystaline oxide surface. Specific and non-specific adsorption on oxide surfaces accounted for 60 to $90 \%$ and 40 to $10 \%$ of the total $\mathrm{Zn}$ adsorption, respectively (Kalbasi et al., 1978). Adsorption of $\mathrm{Zn}$ by oxides occurs, although the exact mechanisms of adsorption on oxide surface are not clear. Quirk and Posner (1975) have suggested that the specific adsorption of $\mathrm{Zn}^{2+}$ involves the formation of a olation bridge and ring structure which can be viewed as an extension of the oxide surface: 


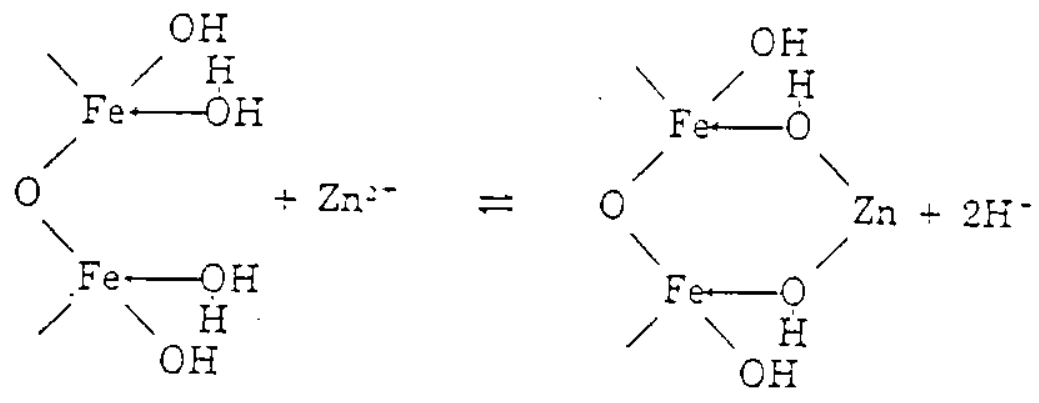

A second mechanism of non-specific adsorption of $\mathrm{Zn}$ at $\mathrm{low} \mathrm{pH}$ values was postulated by Kalbasi et al. (1978) involve adsorption of $\mathrm{ZnCl}$ or $\mathrm{Zn}^{2+}$ plus $\mathrm{Cl}^{-}$and the release of one $\mathrm{H}$ ion for each mole of $\mathrm{Zn}^{2+}$ adsorbed. They proposed the following adsorption reaction:

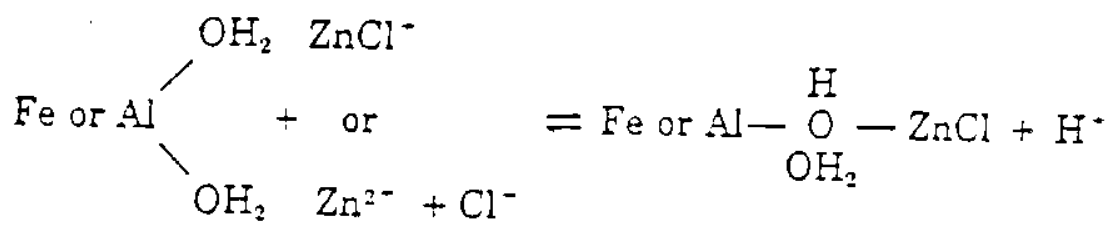

The adsorption of $\mathrm{Zn}$ by the hydrolytic product of $\mathrm{Al}$ is a process involving the formation of specific bonds (Goh et al., 1983). Well-crystallized Al hydroxides formed in the absence of tannic acid are least important in the adsorption of $\mathrm{Zn}$ (Goh et al., 1983). The presence of tannic acid contributes to the adsorption of $\mathrm{Zn}$ by perturbing the crystallization of hydrolytic products of $A 1$ and the subsequent increase in the specific surface and exposure of $\mathrm{Al}-\mathrm{OH}$, carboxylate and phenolic groups of the hydrolytic products.

In addition to $\mathrm{Fe}$ and $\mathrm{Al}$ hydrous oxides, $M$ n oxide can also adsorb Zn. Loganathan et al. (1977) found specific adsorption of $\mathrm{Zn}$ 
by $\delta \mathrm{MnO}_{2}$ at low and higher $\mathrm{pH}$ values. Zinc was exchanged with bound $\mathrm{H}^{+}$at $\mathrm{pH}$ values below 5. At higher $\mathrm{pH}$ values $\mathrm{Zn}$ adsorption increased abruptly and was related to hydroxylation. These workers proposed that $\mathrm{Zn}(\mathrm{OH})_{2}$ was nucleated at the surface.

A characteristic feature of the specific adsorption of $\mathrm{Zn}$ is that it is highly $\mathrm{pH}$ dependent. At trace concentration $\left(<10^{-7} \mathrm{M}\right)$, $\mathrm{Zn}$ adsorption by ferrinydrite increased by about 45 times for each unit increase in pH (Kinniburgh and Jackson, 1982). This strong pHdependene has been interpreted in terms of several mechanisms, namely, the preferential adsorption of $\mathrm{ZnOH}^{+}$, the formation of surface- $\mathrm{Zn}(\mathrm{OH})_{2}$ species or the exchange of $\mathrm{Zn}^{2+}$ for surface-bound protons. Whatever the particular mechanism, the net ef fect is that for adsorption of each $\mathrm{Zn}^{2+}$ there is a release of protons (Quirk and Posner, 1975; . Forbes et al., 1976; Kalbasi et al., 1978; Goh et al., 1983; Kinniburgh, 1983). These studies show that approximately 2 moles of $\mathrm{H}^{+}$are released from the surfaces of well-crystalized gibbsite or goethite for every mole of $\mathrm{Zn}$ adsorbed. However, this stoichiometry was not observed for hydrolytic products of Al containing substantial amounts of poorly crystalline materials (Goh et al., 1983). If the adsorbed ions in the stern plane are close to the surface, the proton release is almost equivalent to the charge on the metal ions; as the distance increases, proton reiease decreases (Barrow et al., 1981).

\subsection{Reaction with Organic Matter}

The formation of complexes between organic matter and $\mathrm{Zn}$ is of fundamental importance in determining $\mathrm{Zn}$ mobility and plant availability. Soluble organic compounds such as simple aiiphatic acids, 
amino acids, phenolic acids, peptides and proteins, simple sugars and polysaccharides, and humic and fulvic acids complex the majority of $\mathrm{Zn}$ in soil solution. Although many of the complexing agents are shortlived in soils, biological processes are constantly replenishing them (Stevenson and Ardakani, 1972).

The role of organic matter on $Z$ n availability may vary depending on the characteristics and amount of organic material involved. In many ways organic matter keeps $\mathrm{zn}$ available to the plants. However, organic soils are of ten deficient in $2 \mathrm{n}$. Matsuda and Ito (1970) found that the adsorption strength of $\mathrm{Zn}$ for humus increases as humification progresses. Insoluble $2 n$ complexes are most likely bound to the humic acid fraction, while soluble 2 n complexes are mainly associated with individual biochemical molecules (stevenson and Ardakani, 1972).

Randhawa and Broadbent (1965) explained the strong pH dependence of complexed $\mathrm{Zn}$ as follows: Complexing agents, which may be considered as Lewis bases (electron donors), have considerable affinity for hydrogen ions as welll as metal ions (electron acceptors). Hydrogen ions compete with the metal ion for the ligand. Thus a decrease in $\mathrm{pH}$ results in a reduction of the free ligand concentration and a decrease in the amount of metal complexed. The result is that, at higher $\mathrm{pH}$ values, more complexing sites are available on humic acid molecules for combination with $\mathrm{Zn}$. Schnitzer and Skinner (1966) reported $2 n-f u l v i c$ acid stability constants of 1.73 at $\mathrm{pH} 3.5$ and 2.34 at $\mathrm{pH} 5.0$. Since bonding of metals to fulvic acid involves carboxyl groups, the $\mathrm{pH}$ dependence of the stability constant reflects the competition with hydrogen ions. Whenever possible, it 
would be preferable to eliminate the $\mathrm{pH}$ dependence of the metal-fulvic complexes in determining stability constants.

Binding of $\mathrm{Zn}^{2+}$ and $\mathrm{Mg}^{2+}$ on several humic and fulvic acid-like model polymers was studied by zunino et al. (1979). Polymers containing carboxylic and phenolic $\mathrm{OH}$ groups show higher coordination power for $\mathrm{Zn}^{2+}$ than those containing only OH groups.

Complex reactions of $\mathrm{Zn}$ with organic matter extracted from sewage sludge were studied by Tan et al. (1971). They reported that both the complexing power and the stability constant of fulvic compounds increased with increasing pH. A shift in infrared characteristics of $\mathrm{OH}$ band from $3500 \mathrm{~cm}^{-1}$ to $3200 \mathrm{~cm}^{-1}$ and sharp increase in carboxyl stretching at $1650 \mathrm{~cm}^{-1}$ and $1400 \mathrm{~cm}^{-1}$, indicated the formation of coordinate covalent bonds between $\mathrm{OH}$ groups and $\mathrm{Zn}$ and linkage between $\mathrm{COO}^{-}$and $\mathrm{Zn}$, respectively. The role of phenolic $\mathrm{OH}$ as Zn binding ligands has also been documented by Abd-Elfattah and Wada (1981) and Goh et al. (1983).

\subsection{Phosphorus $\mathrm{X}$ Zinc Interaction}

High levels of available $P$ or the heavy application of $P$ to the soil induce $\mathrm{Zn}$ deficiency in plants grown in soil or culture media low in available $\mathrm{Zn}$ (Olsen, 1972). This $\mathrm{P} X \mathrm{Zn}$ interaction, generally known as "P induced $\mathrm{Zn}$ deficiency", has been recognized for many crops such as corn (Langin et al., 1962), potatoes (Boawn and Leggett, 1964); tomatoes (Martin et al., 1965); soybean (Paulsen and Rotimi, 1968); flax (Moraghan, 1980); and blackbeans (McKenzie and Soper, 1983)

Despite so many studies, elucidation of the mechanism of the $p$ 
$\mathrm{X} \mathrm{Zn}$ interaction has been controversial. The effects of $\mathrm{P}$ treatment on plant response to $\mathrm{Zn}$ are numerous and complex involving a number of factors. In general, efforts have been concentrated on four possible causes: (i) a PX Zn interaction in the soil, (ii) a simple diiution effect on concentration in plant tops due to growth response to $P$; (iii) a slower rate of translocation of $\mathrm{Zn}$ from the roots to tops; and (iv) a metabolic disorder within the plant cells related to an imbalance between $\mathrm{P}$ and $\mathrm{Zn}$ (01sen, 1972).

In earlier studies, the cause of $P$-induced $Z n$ deficiency was suspected to be the formation of an insoluble $\mathrm{Zn}_{3}\left(\mathrm{PO}_{4}\right)_{2}$ in the soil, which reduced the concentration of $\mathrm{Zn}$ in the soil solution to deficiency levels. However, this was not observed in experiments testing the solubility of this compound (Jurinak and Inouye, 1962). Even when the solubility was at minimum, it was over 100 times greater than the $\mathrm{Zn}$ concentration required for maximum plant growth as determined by Carroll and Loneragan (1969). Moreover, $\mathrm{Zn}_{3}\left(\mathrm{PO}_{4}\right)_{2}$ is an effective $\mathrm{Zn}$ fertilizer (Boawn et al., 1957) and higher $\mathrm{P}$ rates either increased or did not affect extractable soil $\mathrm{Zn}$ levels (Pauli et al., 1968; Brown et al., 1970; Racz and Haluschak, 1974; Safaya, 1976). This evidence clearly indicated that precipitation in the soil is not likely to be the cause of a P-induced 2 n deficiency in plants. When the rate of plant growth exceeds the rate of uptake of a particular nutrient, the concentration of that nutrient in the tissue decreases or in other words dilution occurs. Several studies (Boawn et al., 1954; Loneragan et al., 1979; Moraghan, 1980) observed that a reduction in $\mathrm{Zn}$ content of crops as a result of applied $\mathrm{P}$ produced $\mathrm{Zn}$ deficiency symptoms. Applied $\mathrm{Zn}$ increased yield only when $\mathrm{P}$ was 
appiled. A response in yield was found for appiled P. Hence, a dilution effect upon Zn largely accounted for this interaction. This explanation fits many cases of interaction, but not all. In general, this interaction occurs when the soil is deficient in $P$ and marginal in $\mathrm{Zn}$ (0lsen, 1972). It is therefore likely to be a very important component of $P X \mathrm{Zn}$ interactions observed in the field.

Another mechanism related to $\mathrm{P} X \mathrm{Zn}$ interaction was reported by Stukenholtz et al. (1966). They observed that although the concentration and uptake of $\mathrm{Zn}$ by corn roots increased with applied $P$, concentration and uptake in the leaves, nodes, and internodes declined. From an analogous experiment, Sharma et al. (1968) observed the distribution of $\mathrm{Zn}$ in corn and tomato roots and tops. Concentration and uptake of $\mathrm{Zn}$ in roots, in comparison to the tops, was higher in $P$ treated plants. The findings of these studies suggested that applied $P$ had little or no effect on $Z n$ absorption by roots. The main effect was a physiological inhibition in the translocation of $\mathrm{Zn}$ from roots to tops.

Andriano et al. (1971) have shown that the root cell wall can bind $\mathrm{Zn}$ in sufficient amounts to prevent cytoplasmic toxicity due to Zn. Further, the binding capacity of root cell wall increases in the presence of high $P$ levels (Youngdahl et al., 1977) resulting in less Zn available for transportation to the upper portion. The observation that soils high in $\mathrm{Zn}$ or soils that have been fertilized with $\mathrm{Zn}$ do not show the $\mathrm{P}$-induced $\mathrm{Zn}$ deficiency can be explained since the binding sites in the celi wall are saturated, and any additional $\mathrm{Zn}$ would be available for metabolism.

A number of authors have also observed that $P$ treatments 
sometimes enhanced symptoms of $\mathrm{Zn}$ deficiency without reducing concentration in tops. The symptons correlated with the ratio of concentration of $\mathrm{P} / \mathrm{Zn}$ but not with $\mathrm{Zn}$ concentration (Boawn and Leggett, 1964; Watanabe et al., 1965; Boawn and Brown, 1968; Millikan et al., 1968). These observations suggest that increasing concentration in plant tissue induces a higher physiological requirement for Zn. However, this phencmenon has been the most confusing one, since several other studies have tended to discount the concept of a critical $\mathrm{P} / \mathrm{Zn}$ ratio (Stukenholtz et al., 1966; Sharma et al., 1968; Warnock, 1970; Loneragan et al., 1979; Moraghan, 1980).

More recently Loneragan et al. (1982) studying the $\mathrm{P} X \mathrm{Zn}$ interaction in a solution culture experiment with okra clarified the above mentioned puzzling phenomenon responsible for $P X$ Zn interaction. They showed that $\mathrm{P}$-induced $\mathrm{Zn}$ deficiency lies not on $\mathrm{Zn}$ metabolism in the leaves but rather on $P$ absorption and transport from roots. Under conditions of low $\mathrm{zn}$ and high $\mathrm{P}$ supply, $\mathrm{P}$ accumulates to toxic levels in leaves inducing or accentuating symptoms resembling $\mathrm{Zn}$ deficiency. However, the relevance of $\mathrm{P}$ toxicity resembling $\mathrm{Zn}$ deficiency from solution culture experiments has yet to be established under field conditions.

Another factor which may be involved in the $P \mathrm{X}$ Zn interaction is mycorrhizal infection of plant roots. Tinker and Gildon (1983) cited a number of references reporting increased $\mathrm{z}$ n uptake by crops due to mycorrhizal inoculation. High levels of $P$ can inhibit infection of plant roots with vesicular-arbuscular mycorrhizae (VAM) (Hayman, 1978; Tinker, 1980). Therefore, it seems likely that one of the mechanisms operating to produce this antagonism is that $P$ tends to 
reduce VAM infection. Lambert et al. (1979) tested this idea with soybeans and corn and showed that adding $P$ fertilizer significantly reduced 2 n uptake in mycorrhizal plants.

\subsection{Factors Affecting Zn Availability}

The types of soils inherently low in available $\mathrm{zn}$ include acid sandy soils, some organic soils, particularly peats and humic gley soils, calcareous soils, and subsoils exposed by land leveling operations or by wind or water erosion (Lucas and Knezek, 1972). Factors which 1 imit the rate of diffusion of $Z n$ to plant roots also reduce $\mathrm{Zn}$ availability. This perhaps is the most probable reason why Zn deficiency often occurs on compacted soils. As discussed earlier (Section 2.7), Zn deficiencies are also associated with soils with low Zn content and high available soil $P$ levels.

Deficiencies are correlated not with total $\mathrm{Zn}$ in the soil but with a complex soil-plant system. A low total $\mathrm{Zn}$ level may be an important contributory factor but availabiiity is the important Iimiting factor. Factors which favour $\mathrm{Zn}$ fixation, such as high pH, clay, organic matter, oxides, and carbonate content limit $\mathrm{Zn}$ availability. These factors are discussed in detail in Section 2.5 and 2.6 . Zinc deficiencies found during the early growing season of ten disappear by midseason. According to Lindsay (1972), Zn deficiencies in Colorado are most pronounced during cool, wet spring and disappear in July. He suggests that either the cool soil results in poorly established rooting system, thus restricting the feeding zone, or reduced microbial activity causes insufficient available $Z$ n to be released from the organic matter. 
Edwards and Kamprati (1974) considered that the detrimental

effect of low soil temperature in suppressing $2 n$ accumulation in corn was mainly due to lowered translocation from roots to tops. Decreased metabolic activity of plant roots at low soil temperatures was also advanced as a cause of early season $\mathrm{Zn}$ deficiency in corn (Giordano and Mortvedt, 1978).

Plants differ widely in their ability to obtain zn from soil. Differences occur among both varieties and species. From a study of 25 annual crops and pasture plant varieties representing 21 species, Gladstones and Loneragan (1967) found that species differ characteristically in their feeding power for $\mathrm{Zn}$. They suggested that relative differences among species are maintained over a wide range of soils. Differential susceptibility has been shown to occur in navy beans. Ambler and Brown (1969) found that the variety Sanilac was more susceptible to $\mathrm{Zn}$ deficiency than Sagina'. Massey and Loeffel (1967) found wide variations in the $\mathrm{Zn}$ levels of 31 inbred 1 ines of corn. The nature of resistance to $\mathrm{zn}$ deficiency for several inbreds and single corn crosses is believed to be under genetic control (Halim et al., 1968). Sensitivity of various crops to low levels of soil $\mathrm{Zn}$ is shown in Table 2.1 .

\subsection{Diagnosis of Zn Deficiency}

\subsubsection{Soll testing}

Analysis of soil is one means of assessing the available supply of $\mathrm{Zn}$. A wide variety of techniques and extractants have been tested for determining the availabie $z$ n levels of soils.

Accuracy in designating deficient areas is better achieved with 
Table 2.1 Sensitivity of crops to low levels of available zinc in soil (adapted from Tisdale et al., 1982).

Very sensitive

Mildly sensitive

Insensitive

Beans, 1 ima and pea

Castor beans

Citrus

Corn

Elax

Eruit trees (deciduous)

Grapes

Hops

Onions

Pecans

Pine

Rice

Soybeans

Sundangrass
Alfalfa

Barley

Clovers

Cotton

Potatoes

Sorghum

Sugar beets

Tomatoes

Wheat
Asparagus

Carrots

Forage grasses

Mustard and other crucifers Oats

Peas

Peppermint

Rye

Safflower

extractions that estimate the available $\mathrm{zn}$ in the soil. Soil $\mathrm{Zn}$,

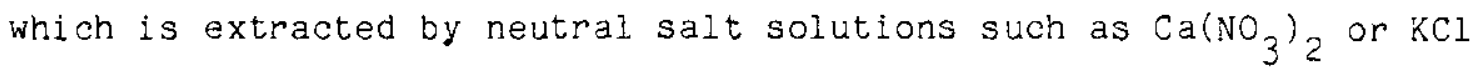
is considered readily available to plant. This portion of $\mathrm{Zn}$, however, is very small, especially in alkaline soils (Tiller et al., 1972). Extractable $\mathrm{Zn}$ extracted with Ca or $\mathrm{K}$ salts, is not considered useful in interpreting the $\mathrm{Zn} \mathrm{labile} \mathrm{pool.} \mathrm{Extraction} \mathrm{with} 2 \mathrm{~N} \mathrm{M}_{2}$ was shown to be a very good estimate of the $\mathrm{zn}$ supplying power of 20 soils that varied considerably in pH (5 to 7.6 ), organic matter content and soil texture (Stewart and Berger, 1965). Optimum growth of millet was obtained when the $2 \mathrm{~N} \mathrm{MgCl}_{2}$ extractable $\mathrm{Zn}$ was greater than $0.4 \mathrm{mg} \mathrm{kg}^{-1}$. Martens (1968) extracted 16 soils with $2 \mathrm{~N} \mathrm{MgCl}_{2}$ and 0.1 and $1.0 \mathrm{~N} \mathrm{HCl}$ to predict $\mathrm{Zn}$ uptake by greennouse corn. He found that $2 \mathrm{~N} \mathrm{MgCl}_{2}$ extractable $\mathrm{Zn}$ was closely related to $\mathrm{Zn}$ uptake. Weak acids such as $0.1 \mathrm{~N} \mathrm{HCl}$ have also been evaluated as an 
index of $Z n$ availability. Wear and Evans (1968) compared the effectiveness of $0.1 \mathrm{~N} \mathrm{HCl}$, dilute acid mixture of $0.05 \mathrm{~N} \mathrm{HCl}+0.025$ $\mathrm{N} \mathrm{H}_{2} \mathrm{SO}_{4}$ and $0.05 \mathrm{M}$ EDTA at $\mathrm{pH} 7$ as a means of predicting $\mathrm{Zn}$ uptake by corn plants. The correlation coefficients were 0.89 for dilute acid mixture, 0.82 for $0.1 \mathrm{~N} \mathrm{HCl}$ and 0.62 for EDTA. Although the dilute acid, $0.1 \mathrm{~N} \mathrm{HCl,} \mathrm{was} \mathrm{found} \mathrm{equally} \mathrm{effective} \mathrm{as} \mathrm{Aspergillus} \mathrm{niger}$ (Tucker and Kurtz, 1955) and was highly correlated with chelating agents (Tiller et al., 1972), this test extracts an excess of $\mathrm{Zn}$ from calcareous soils, which is doubtful that it is available to plants. The use of the acid extraction may not be applicable in calcareous soils (Trierweiler and Lindsay, 1969).

Chelating reagents as $\mathrm{Zn}$ extractants are most frequently used to estimate labile $\mathrm{Zn}$ pool. Dithizone-ammonium acetate (Shaw and Dean, 1952), EDTA-ammonium acetate (Viro, 1955; Tucker and Kurtz, 1955), EDTA-ammonium carbonate ( $\mathrm{pH}$ 8.6) (Trierweiler and Lindsay, 1969), and DTPA (Lindsay and Norvell, 1978) have been used. The dithizone method shows a high degree of correlation with extractable $\mathrm{Zn}$ and uptake of $\mathrm{Zn}$ by plants (Marten et al., 1966) and is capable of separating $\mathrm{Zn}$ deficient from non-deficient soils (Trierweiler and Lindsay, 1969). The EDTA-ammonium carbonate (pH 8.6) method was also found to be effective in predicting soil available $\mathrm{Zn}$ (Trierweiler and Lindsay, 1969; Brown et al., 1971; Haq and Miller, 1972).

The DTPA method (Lindsay and Norvell, 1978) seems promising because it simultaneously extracts $Z n, F e, M n$ and Cu. This test was able to successfully separate 42 Colorado soils into $z n$ deficient and non-deficient categories for corn. The critical level for this crop was established at $0.8 \mathrm{mg} \mathrm{kg}^{-1}$. Halvin and soltanpour (1981) 
evaluated the $\mathrm{NH}_{4} \mathrm{HCO}_{3}$-DTPA soil test developed by soltanpour and Schwab (1977). Their results indicate that the $\mathrm{NH}_{4} \mathrm{HCO}_{3}$-DTPA soil test is as good as the DTPA soil test of Lindsay and Norvell (1978) for predicting plant available $\mathrm{Zn}$ in Colorado soils. However, the $\mathrm{NH}_{4} \mathrm{HCO}_{3}-\mathrm{DTPA}$ soil test is more economical because it simultaneously extracts both macro- and micronutrients.

Lindsay and Norvell (1978) cited a number of references reporting on the success of the DTPA method. However, they have clearly suggested that critical levels must be determined separately for each crop using standardized procedures for soil preparation, grinding and extraction. The importance of sample handing, soil drying, soil grinding, suspension shaking and filtering, soil to solution ratio and reaction time in developing a soil test method has been well documented (Soltanpour et al., 1976; Khan and Soltanpour, 1978; Legzett and Argyle, 1983). The use of composite samples, which is the normaliy recommended procedure, can provide mean DTPAextractable micronutrient levels, but of fers no indication of spatial variation within a field. The latter is of great importance in the case of micronutrients as sufficiency and deficiency criteria of ten lie within narrow limits.

\subsubsection{Plant tissue analysis}

Plant tissue analysis reflects the nutrient uptake conditions of the soil. As such, it represents another approach in determining the soil nutrient availability. The diagnosis of nutrient deficiencies, and the prediction of fertilizer requirements from plant analysis, are based on the critical concentration (Farhoomand and 
Peterson, 1968) of a nutrient within plant or some plant part, below which growth or crop yield is restricted. Critical nutrient concentrations have been defined as the nutrient concentration of tissue associated with $10 \%$ reduction from maximum growth due to deficiency (Ulrich and Hills, 1973).

Zinc deficiency occurs in many plants when the leaf concentration in mature plants is less than $20 \mathrm{mg} \mathrm{kg}^{-1}$ in the dry matter (Jones, 1972). Different plants and plant parts vary considerabiy in the levels of $\mathrm{Zn}$ that accompany $\mathrm{Zn}$ deficiencies. For making diagnosis a part of the plant, usually recently matured leaves is preferred for determining $\mathrm{Zn}$ (Viets et al., 1954b; Onki, 1977, 1984). However, Melsted et al. (1969) favoured the analysis of the whole plant at boot stage for wheat.

The concentration of $\mathrm{Zn}$ in a plant is dependent on the physiological stage of the plant. Thus, sampling time is important in the interpretation of plant tissue analysis. Bates (1971) suggested that most C-shaped growth curves could be avoided if the tissue of the same physiological age and the same plant parts are analyzed. Sillanpaa (1982) studied the effect of sampling time on the $\mathrm{Zn}$ content of wheat. Plants were sampled twice a week throughout the growing season. Zinc content of wheat remained relatively constant during the growing season. Thus sampling time may not be as critical for wheat as for other crops (Jones, 1972; Jacques et a1., 1975).

The time of sampling is particularly important when plants are under stress, and especially when they are initially affected. When deficiency probiems are suspected, comparative analysis of normal plant can aid the interpretor (Jones, 1972). However, caution should 
be exercised to select similar plant tissue at the same stage of development (Bates, 1971). Suggested sampling procedures listing growth stage, plant part to be sampled and number of plants to be sampled for field and vegetable crops are summarized by Jones (1972). Often Zn deficiencies are associated with cool or excessively wet conditions early in the season, but the plants grow out of the deficiency later on (Lindsay, 1972). Calibration studies using piant analysis from experiments in such cases are difficult and the likelihood of a response to a $\mathrm{zn}$ fertilizer is probably dependent on the yield potential and the length of the deficiency period Moraghan, 1985). Nutrient interaction and environmental variables such as moisture supply can markedly alter the nutrient content of the plants (Bates, 1971). Therefore, the blind acceptance of individual critical values or ranges must be viewed with caution.

\subsection{Zinc Fertilizers and Correction of Zn Deficiency}

Zinc deficiencies are relatively easy to correct using foliar or soil applied $\mathrm{Zn}$ or trunk injection to trees. Recommended rates of Zn vary considerably depending upon the crop, the source, the soil, the severity of deficiency, and the methods of application (Murphy and Walsh, 1972). Typical application rates for foliar Zn sprays are $0.9-4.5 \mathrm{~kg}$ of $\mathrm{ZnSO}_{4} \cdot 7 \mathrm{H}_{2} \mathrm{O}$ per 378 liters of water applied at early stages and repeated as required (Lindsay, 1972). Soil $\mathrm{Zn}$ application

rates vary from 2 to $22 \mathrm{~kg} 2 \mathrm{n} \mathrm{ha}^{-1}$ and 0.3 to $6 \mathrm{~kg} \mathrm{nn} \mathrm{ha}^{-1}$ for inorganic and organic sourses, respectively.

Both band and broadcast and incorporated applications of $\mathrm{Zn}$ are effective in correcting $\mathrm{Zn}$ deficiency. Boawn (1973) reported that 
banded chelates are 2.5 times more effective than zn sulfate. on the other hand, banded $\mathrm{Zn}$ sulfate has lower availability coefficient than Zn sulfate broadcast and plowed down. Zinc applied as inorganic salts is relatively immobile in soils (Brown et al., 1962). Surface application of $\mathrm{Zn}$ has been proven in several cases to be relatively ineffective for upland crops as compared to applications that involve mixing into the soil (Barrow et al., 1960; Brown et al., 1962; Boawn, 1973)

Foliar applied $\mathrm{Zn}$ is usually considered as a temporary, annual corrective measure taken after deficiency symptoms occur (Murphy and Walsh, 1972). According to Chapman (1966), foliar applications have been most successful for correcting $\mathrm{Zn}$ deficiency in trees. Boawn and Leggett (1963) could not correct $Z n$ deficiency in Russet Burbank potatoes by $Z n$ sprays after deficiency symptoms had developed. In contrast, Murphy and Walsh (1972) reported success by other workers. For example, $\mathrm{Zn}$ deficiency in corn in Australia could be controlled if the crop was sprayed one or two times with a solution of $0.5,1.0$ or $1.5 \% \mathrm{ZnSO}_{4}$ beginning 5 weeks after emergence.

Among inorganic sources, $\mathrm{Zn}$ sulfate is one of the most commonly used $\mathrm{Zn}$ fertilizers. Other inorganic compounds such as $\mathrm{ZnO}, \mathrm{ZnCO}_{3}$ and $2 \mathrm{n}_{3}\left(\mathrm{PO}_{4}\right)_{2}$ are sufficiently soluble to supply available $\mathrm{Zn}$ to plants (Lindsay, 1972). Attempts have been made to compare the relative efficiency of organic and inorganic $\mathrm{Zn}$ fertilizers. Boawn et al. (1957) reported that when $2 \mathrm{mg}^{2 \mathrm{n} \mathrm{kg}^{-1}}$ was applied to an alkaline silt loam in pots, bean plants took up 3.5 times more Zn from ZnEDTA than from Zn sulfate. Brown and Krantz (1966) and Shukla and Morris (1967) using pot cultures, reported that $\mathrm{Zn}$ uptake by corn from $\mathrm{ZnSO}_{4}$ and 
ZnEDTA was comparable when the sources were mixed into the soils. However, when $\mathrm{Zn}$ sources were banded under the seed, ZnEDTA was more effective than Zn sulfate (Brown and Krantz, 1966; Boawn, 1973).

Gallagher (1978) reported that organic 2 n sources supply more Zn to the plants grown on acid soil at low temperature but high temperature reversed this trend. The organic $\mathrm{Zn}$ sources were slightly more effective than inorganic sources on calcareous soils at both temperatures. 


\section{MATERIALS AND METHODS}

To meet the objectives of this thesis a number of field, growth chamber and laboratory experiments and exploratory surveys were carried out. Analytical procedures adopted for soil and tissue analysis common in all these studies are described in a separate section (3.4) under "Analytical Procedures".

\subsection{Spatial Variability of $\mathrm{Zn}$}

3.1.1 Spatial variability of $\mathrm{Zn}$ in relation to other micronutrients in uniform topography

To study the spatial variability of DTPA-extractable $\mathrm{Zn}, \mathrm{Cu}$, Fe, and $M n$, two transects were sampled, one in a cultivated field and the other $8 \mathrm{~m}$ away in an adjacent native prairie field. Each transect was $46 \mathrm{~m}$ long located in a flat well-drained area. The fields were chosen for their apparent uniformity and the overali slope of each transect was less than $0.4 \%$. The soils of both the transects were Brooking clay loam (Dark Brown Chernozemic) developed on a glacial parent material. Soil cores $(76 \mathrm{~mm}$ diameter) were taken from the $A$ and $B$ horizon of both transects at $1 \mathrm{~m}$ intervals.

\subsubsection{Spatial variability of $\mathrm{Zn}$ in undulating topography}

This study was conducted to evaluate the influence of slope position on the spatial variability of DTPA-extractable $\mathrm{Zn}$ and wheat tissue $2 n$ concentration at FEEKES-10 growth stage. Four transects were sampled from Weyburn loam soil (Dark Brown Chernozemic) with undulating topography as shown in Figure 3.1. Three transects A, B 


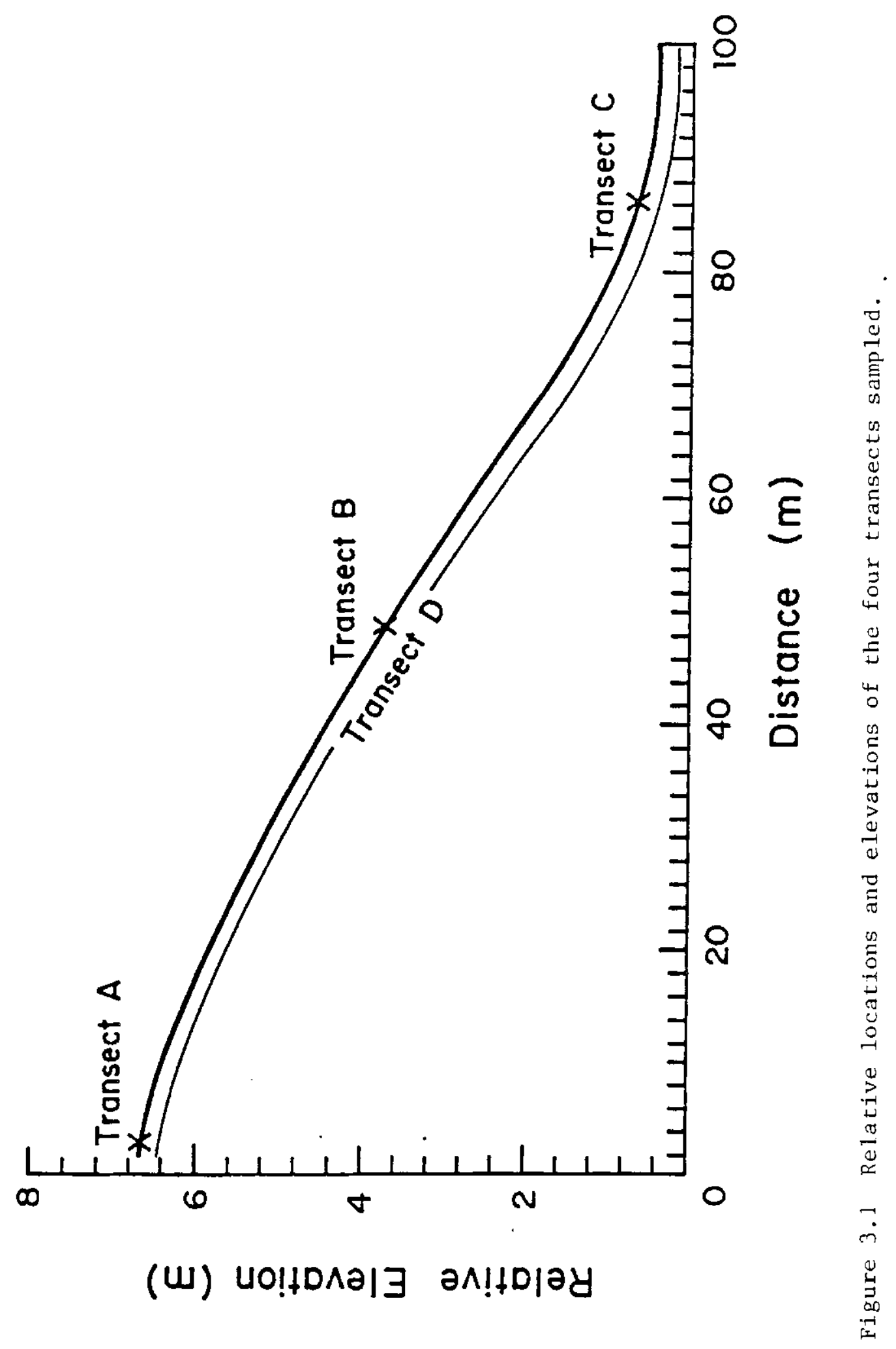


and $\mathrm{C}$, each $50 \mathrm{~m}$ long were sampled at $1 \mathrm{~m}$ intervals across the slope on the upper, middle and lower slope positions, respectively. The fourth transect, D, $100 \mathrm{~m}$ long was sampled every $2 \mathrm{~m}$ along the slope. Three samples were collected from each site representing the 0 to $15 \mathrm{~cm}$ depth using a $25 \mathrm{~mm}$ dianeter probe and composited for analysis. A flag was placed at each point of soil sampling. A composite sample of two plants was obtained adjacent to the point of soil sampling when the wheat was at FEEKES-10 growth stage.

\subsubsection{Soil and plant tissue analyses}

Soil samples from both studies were processed as described in Section 3.4 .1 and were assayed for available $Z$ n using the DTPA method (Section 3.4.1.7). In addition to $\mathrm{Zn}$, soil samples from the uniform field were analyzed for DTPA extractable $\mathrm{Cu}, \mathrm{Fe}$ and $\mathrm{Mn}$ and those from the undulating field for $\mathrm{pH}$, texture, and inorganic and organic $\mathrm{c}$ (Sections $3.4 .1 .1,3.4 .1 .2$ and 3.4 .1 .6 , respectively). Wheat tissue samples were analyzed according to the procedure outlined in Section 3.4.2.

\subsubsection{Statistical Approach}

\subsubsection{Classical statistics}

The classical statistical technique was used to describe the variability of the data by calculating mean, standard deviation, and coefficient of variation. The sample mean $\left(U_{E}\right)$, standard deviation $\left(S_{E}\right)$ and coeficient of variation (CV) were calculated from:

$$
\begin{aligned}
U_{E} & =\sum X i / n \\
S_{E} & =\left[\Sigma\left(X i-U_{E}\right)^{2} /(n-1)\right]^{1 / 2} \\
C V & =(S / U) \times 100
\end{aligned}
$$


Before calculation of sample numbers, the amount of skewness and kurtosis was examined in the data. Normal distribution was found for all the data except Mn in the A horizon of native prairie soil, which was log-normally distributed. An estimate of the number of samples necessary to estimate the mean within a given precision with a specific probability was obtained from the equation:

$$
N=t_{\alpha}^{2} s^{2} / D^{2}
$$

where $N=$ number of cores required, $t_{\alpha}=$ student $t$ with $(n-1)$ degrees of freedom at the $\alpha$ probability level, $s=$ standard deviation, and $D$ is the specified limit of precision (Peterson and Calvin, 1965). This equation was used to calculate the number of samples required to estimate the mean within $5 \%$, $10 \%$ and $20 \%$ at the $5 \%$ probability level.

\subsubsection{Geostatistics}

The classical approach to describe variability of soil parameters considers them as a simple random variable and includes only two characteristics, the mean and the variance. However, this approach neglects the spatial correlation structure inherent in soils. In these circumstances, the alternative is to use geostatistical methods which take into account the spatial structure of the data. The geostatistical approach applied in this study is described by Journel and Huijbregts (1978). Geostatistics is based on the theory of regionalized variables. A variable distributed in space and/or time is said to be regionalized. Corresponding to random function $Z(X)$, a random variable $Z\left(x_{1}\right)$ can be compared to another random variable $z\left(x_{1}+h\right)$ which is distance or time $h$ away from $z\left(x_{1}\right)$. The variable $Z(x)$ is a regionalized variable.

Unlike most classical statistics, the assumption of independence is 
not made, thus the random variables $Z(x)$ and $Z(x+h)$ may or may not be dependent. According to the regionalized variable theory, a variogram function (which is basic to geostatistics) is defined as:

$$
2 y^{(h)}=\operatorname{var}[z(x)-z(x+h)
$$

Taking a simplistic one-dimensional case, e.g. along a transect, and assuming stationarity (i.e. $E[Z(x)]$ equals a constant) we define the semi variogram by

$$
\gamma(h)=1 /{ }_{2} E[Z(x)-Z(x+h)]^{2}
$$

and the sample semi variogram by

$$
\gamma(n)=(-\infty) \sum_{2 n}^{n}\left[z\left(x_{1}\right)-z\left(x_{1}+n\right)\right]^{2}
$$

where $\gamma$ is a function of $h$, the distance between samples. The semivariogram is developed by plotting semivariance with respect to $h$.

The resulting semivariograms can be fitted to mathematical models which are necessary for subsequent applications, e.g. kriging. Valid possibilities include linear, spherical, exponential, Gaussian and power models. To date there is not a foolproof, purely objective method for fitting models to sample semivariograms. As a result, models are fitted subjectively by weighting more heavily where large numbers of sample pairs are available and pairs relatively close together. Journel and Huijbregts (1978) suggested that distance intervals ( $h$ ) should be selected to provide at least 25 to 30 pairs of points in each interval to arrive at stable estimates of the semivariogram. The sample semivariograms for this study are modelled using a linear equation $(y=a+b x)$ weighted for the number of pairs in each distance interval ( $h$ ). 
The shape of semi variogram gives an indication of the spatial dependence of the soil property. If for all values of 1 ag greater than zero, $\gamma(h)$ is approximately constant, the semivariogram indicates that the observations are spatially independent. If, on the other hand, values of $\gamma(h)$ approach the variance gradually or in some consistent manner as the value of lag increases, the observations are spatially dependent.

The 1 inear semivariogram model is given as Figure 3.2. The semivariance starts at $C_{0}$ for $h=0$, where $c_{0}$ is called the "nugget" value and is due to inherent variability of the characteristic, type of sampling and or laboratory analysis error. From $C_{0}$ the value increases linearly with distance between samples, h, to maximum "sill" value, $c_{0}+\Delta_{c}$, where $\Delta_{c}$ is the $h$ dependent change in semivariance.

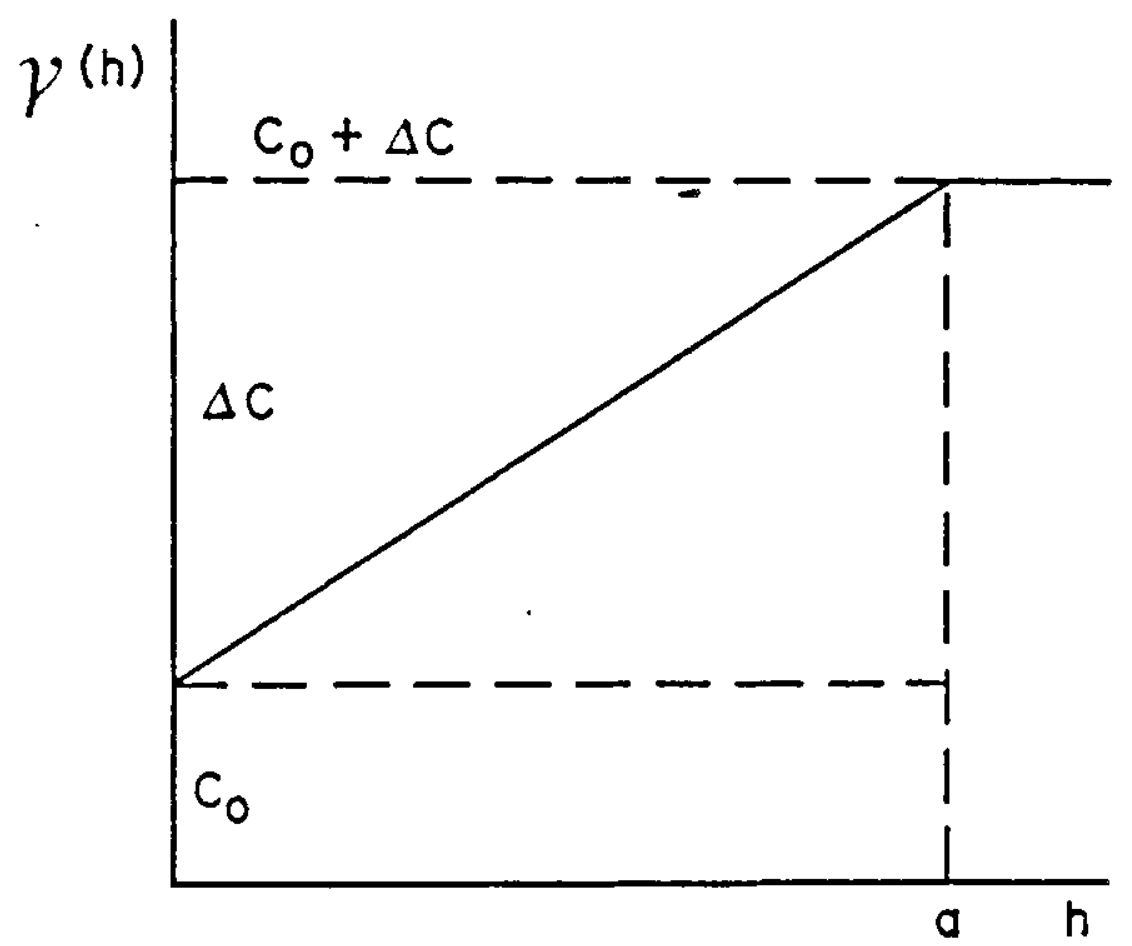

Figure 3.2 A linear semi variogr am model. 
The sill value remains constant with intersample distances greater than or equal to the "range", a. Thus, samples are dependent for distances up to range "a" where semivariance then remains constant with increasing distances between samples and samples achieve independence.

3.2 Importance of $\mathrm{Zn}$ to Crop Nutrition and Production of Common Crops 3.2.1 Zinc status of Saskatchewan soils

\subsubsection{Exploratory surveys}

DTPA-extractable $\mathrm{Zn}$ levels (Section 3.4.1.7) from approximately 1200 fields from the province of Saskatchewan were compiled using soil samples submitted by individual farmers to the Saskatchewan soil Testing Laboratory (SSTL) and others collected by our research team from field research sites. The proportion of samples with low levels of extractable $\mathrm{Zn}$ is probabiy greater than the proportion of $\mathrm{f}$ armland with low levels of extractable $\mathrm{Zn}$. This would be since the survey was primarily based on submissions to SSTL by farmers, who are more likely to test their fields if they suspect $\mathrm{Zn}$ is limiting yields or if reports of $Z n$ deficiency occur in their area. Nonetheless, representation from a wide range of soil types covering many areas of the province was achieved (Fig. 3.3).

Soils in the population studied were arbitrarily classified into three groups on the basis of DTPA-extractable $\mathrm{Zn}$. Class $1(<0.5$ mg $\mathrm{Zn} \mathrm{kg}^{-1}$ ) included soil samples with extracted $\mathrm{Zn}$ levels below the critical level adopted by the SSTL. Class 2 included extracted $\mathrm{Zn}$ levels in the marginal range $\left(0.5-1.0 \mathrm{mg} \mathrm{Zn} \mathrm{kg}^{-1}\right)$ and $\mathrm{Class} 3$

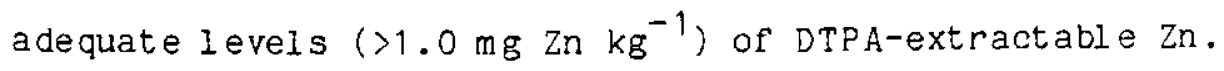




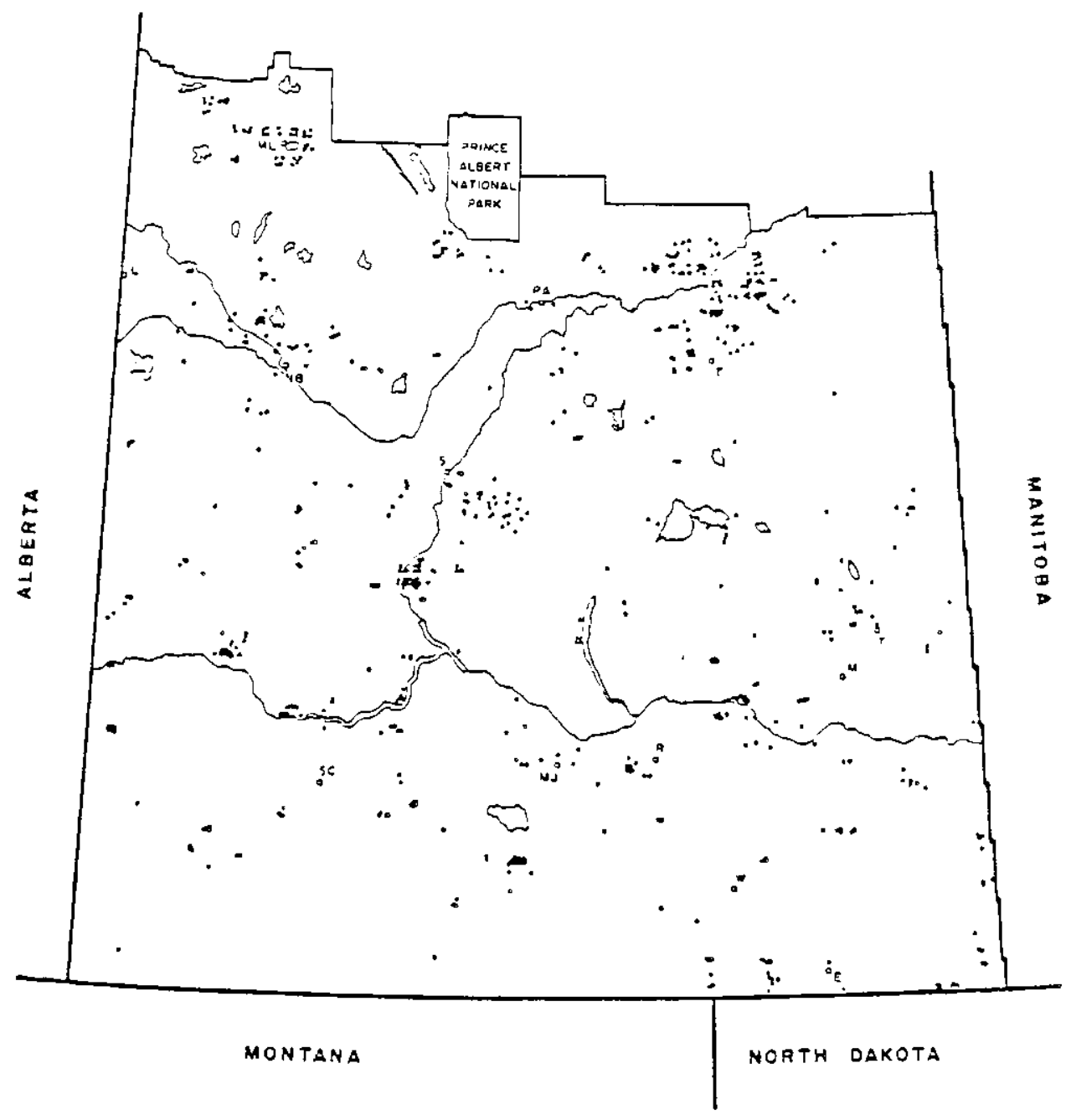

Figure 3.3 Distribution of micronutrient sampling sites in Saskat chewan (1982-83). 
Following classification of the soils in the three classes above, the population of the samples was superimposed on soil maps to establish $\mathrm{Zn}$ levels trend in various soil associations.

\subsubsection{Field experiments with Zn fertilizers}

\subsection{Experimental design}

Twenty-three field trials that were established in 1982 and 1983 on a number of Saskatchewan soils of diverse soil characteristics (Tabie 3.1) were considered in order to assess crop responses to applied $\mathrm{Zn}$.

Basal applications of $N, P$ and $K$ were applied to each field trial according to soil testing recommendations to ensure that available macronutrients did not limit yield. Sulfur was applied in two different ways. In 1982 , a treatment of $\mathrm{Na}_{2} \mathrm{SO}_{4}$ containing amounts equivalent to those added by $\mathrm{ZnSO}_{4}$ was included in all experiments where this fertilizer form was used. In 1983, basal applications of $30 \mathrm{~kg} \mathrm{~S} \mathrm{ha} a^{-1}$ as ammonium sulfate were applied over the whole experimental site. The experiments were designed as completely randomized demonstration strips (3.05 m $\times 30.5 \mathrm{~m}$ plot size) in 1982 and randomized complete block design $(3.05 \mathrm{~m} \times 6.10 \mathrm{~m}$ plot size) in 1983. With the exception of $S$ application, the basic design included a control and one or more $2 n$ treatments. Zinc was broadcast either as Zn oxide or $Z n$ sulfate shelf chemical or as Zn sulfate fertilizer at a rate of $10 \mathrm{~kg} \mathrm{Zn} \mathrm{ha} \mathrm{C}^{-1}$ or sprayed as $\mathrm{Zn}$-chelate (poiylignosul phonic acid) on the soil or foliage at a rate of 1 or $0.35 \mathrm{~kg} \mathrm{zn} \mathrm{ha}{ }^{-1}$, respectively. Soil application of fertilizers or shelf chemicals was always followed by incorporation. Foliar applications for all cereals 


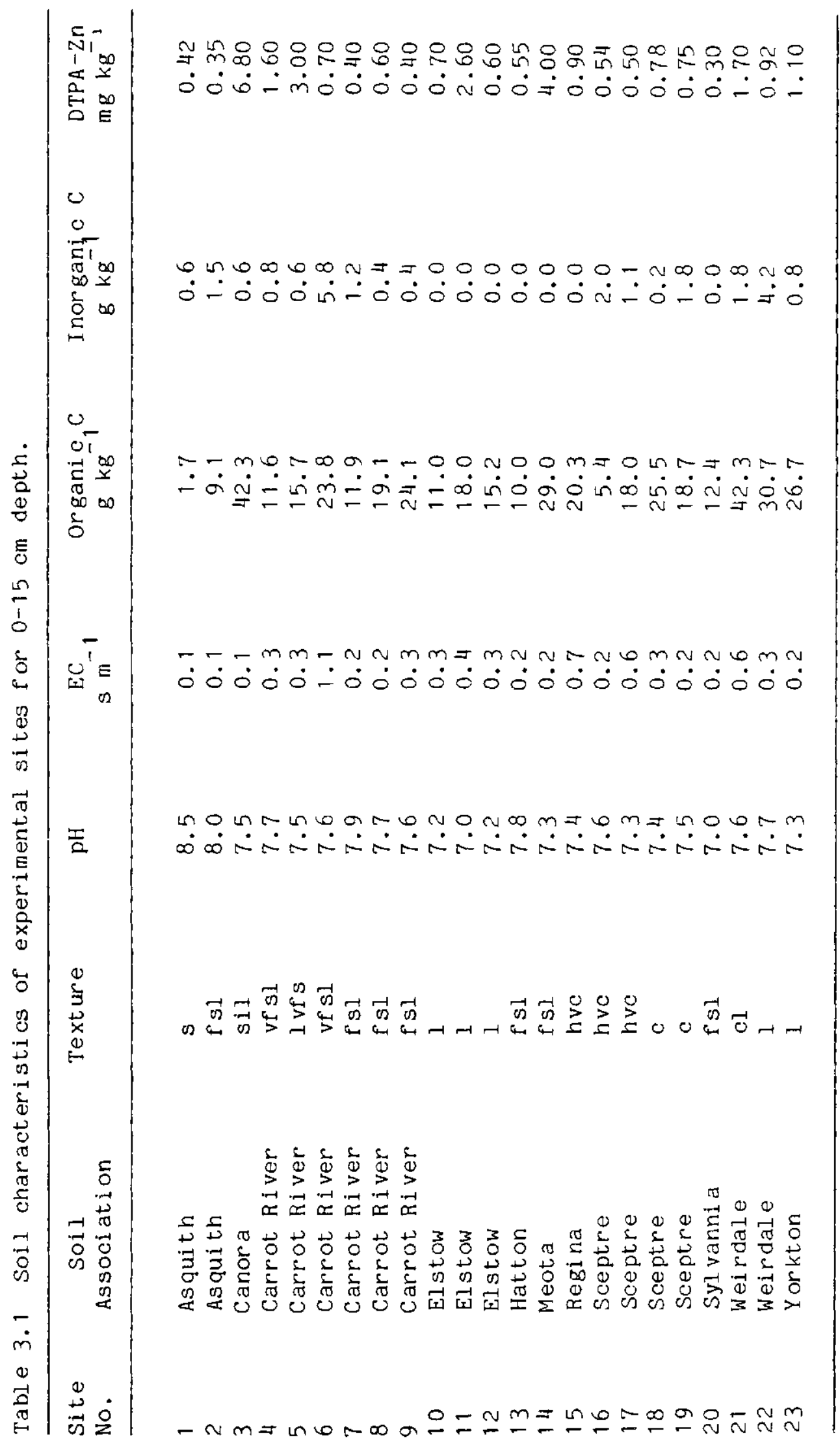


were applied at the FEEKES-6 (first node of stem visible at the basis of shoot) and/ or FEEKES-10 (sheath of the I ast leaf extended with the ear swollen but not yet visible) growth stages and for corn at the mid whirl stage. All treatments were replicated four times. In 1984 , crops were grown in four of the experiments initiated in 1983 to assess residual effects of $\mathrm{Zn}$ fertilizers. Basal applications of macronutrient fertilizers were made according to corresponding 1983 schedule.

\subsection{Soil and plant tissue sampling and analyses}

Composite soil samples $(0-15 \mathrm{~cm})$ were taken from the whole experimental site in 1982 and from each block in 1983 prior to fertilizer applications. In 1984, four 20-mm in dianeter by $150-\mathrm{mm}$ deep cores were obtained from each plot in all 1983 experiments in which residual fertilizer was assessed. Composite samples were then made on a per treatment basis ( 4 plots) in all experiments.

Plant tissue samples were collected once during the growing season in 1982 and twice in 1983 at the growth stage at which foliar Zn applications were made (Section 3.2.1.2.1) and prior to the foliar application. In certain cases, separate whole plant and flagleaf samples were obtained at FEEKES-10 growth stage. One-half of each plot was utilized for the tissue sampling program. Tissue samples at each of the two growth stages sampled in 1983 were obtained from a separate one-quarter of each plot. At maturity, above ground plant materials from a $1.6 \mathrm{~m}^{2}$ area in the remaining half of each plot were harvested, dried and grain or seed separated. The DTPA extraction (Section 3.4.1.7) was used to assess available $\mathrm{zn}$ Ievels in all 
experiments. Zinc in extracts was determined by atomic absorption spectrophotometry. Harvested plant materials were processed according to the procedure outlined in section 3.4 .2 .

\subsection{Statistical analysis}

All yield and tissue content data were subjected to analys is of variance for a completely randomized design in 1982 and a randomized complete block design in 1983 and 1984. Duncan's multiple range test was used to separate si gnificantly different means.

\subsubsection{P X Zn interaction in wheat}

\subsubsection{Experimental design}

This study was conducted on an ongoing field experiment, which was established in 1979 to assess the residual effect of a single broadcast application of a large amount of p fertilizer for crop growth. The site had been established on a Sutherland soil (Dark Brown Chernozemic) with clay texture, ph 7.3 , organic $c$ of $34.3 \mathrm{~g}$ $\mathrm{kg}^{-1}, \mathrm{CEC}$ of $46 \mathrm{cmoles} \mathrm{kg}^{-1}$ and $<3 \mathrm{mg} \mathrm{P} \mathrm{kg}^{-1}$ soil of $\mathrm{NaHCO}_{3}^{-}$ extractable $P$ (OIsen et al., 1954) in the $0-15 \mathrm{~cm}$ depth. A single application of $0,20,40,80$ or $160 \mathrm{~kg} \mathrm{Pha}^{-1}$ from triple superphosphate (0-45-0) was broadcast on the main plots $(13.7 \mathrm{~m} \times 30.5 \mathrm{~m}$ ) arranged in a $5 \times 5$ latin square design and incorporated in the spring of 1979 prior to first seeding of a continuous hard red spring wheat (Triticum aestivum L. cv. Neepawa) system.

In 1984 , three factorial experiments were created by maintaining the 0,80 and $160 \mathrm{~kg} \mathrm{P} \mathrm{ha}^{-1}$ treatments as main plots and superimposing various rates of soil applied $\mathrm{Zn}$-sulfate or $\mathrm{Zn}$-chelate 
(polylignosulfonic acid), or foliar application of $\mathrm{Zn-chelate} \mathrm{as} 2.74$ $m \times 2.74 \mathrm{~m}$ subplots within the main plots. Soil applied treatments of Zn-sulfate $\left(0,5,10\right.$ and $\left.20 \mathrm{~kg} \mathrm{Zn} \mathrm{ha}^{-1}\right)$ and $\mathrm{Zn}$-chelate $(0,0.5,1.0$ and $2.0 \mathrm{~kg} \mathrm{Zn} \mathrm{ha}{ }^{-1}$ ) were broadcast or sprayed, respectively, on the soil surface and incorporated with a small cultivator. Two rates of $\mathrm{Zn}$-chelate ( 0 and $0.35 \mathrm{~kg} \mathrm{Zn} \mathrm{ha}{ }^{-1}$ ) were applied on foliage either at FEEKES-6 or at FEEKES-10 growth stage. All plots received basal application of $\mathrm{N}$ prior to seeding in accordance with the Saskatchewan Soil Testing Laboratory recommendations.

\subsubsection{Soil and plant tissue sampling and analyses}

Prior to Zn application, composite soil samples $(0-15 \mathrm{~cm})$ from each main plot were collected and analyzed for DTPA-extractable $\mathrm{Zn}$ (Section 3.4.1.7) and resin extractable $P$ (Section 3.4.1.5). One-half of each subplot $(1.37 \mathrm{~m} \times 2.74 \mathrm{~m})$ was used for tissue sampling and the remaining hall for harvest at maturity. Composite plant tissue samples were obtained from the S.W. quarter $(1.37 \mathrm{~m} \times 1.37 \mathrm{~m})$ of each subpl ot at FEEKES- 6 and from the S.E. quarter at FEEKES-10 growth stages, respectively.

At maturity, above ground plant material and roots were harvested from the north half of each subplot. The above ground plant material was oven-dried at $60^{\circ} \mathrm{C}$ for $72 \mathrm{~h}$, the grain was separated and grain and straw weight determined. Grain, straw and tissue samples were assayed for $\mathrm{Zn}$ and $\mathrm{P}$ according to the procedure outlined in Section 3.4.2. 


\subsubsection{Mycorrhizal infection}

To assess vesicular-arbuscul ar mycorrhizal (VAM) infection, root samples were rinsed in water, cleaned in hot $10 \% \mathrm{KOH}$ and dipped into $0.01 \mathrm{~N} \mathrm{HCl}$ to neutralize $\mathrm{KOH}$. Twenty $1-\mathrm{cm}$ root sections were selected at random from roots collected at each subplot and stained in 0.05\% trypan blue in lactophenol (Phillips and Hayman, 1970) and VAM infection was assessed microscopically. The number of infected microscopic fields was expressed as a percentage of the total number of mi croscopic fields observed.

\subsubsection{Statistical analyses}

Analyses of variance were performed for a randomized complete block split-plot design. Orthogonal contrasts were used to partition the sum of squares for $P$ and $Z n$ effects and interaction into single degrees of freedom. Orthogonal polynomials were used for the rates of each soil applied $\mathrm{Zn}$ source only, since the control and the high rates of initially applied p selected for this study as well as the foliar Zn treatments were considered discrete.

\subsubsection{P X Zn interaction in beans}

\subsubsection{Experimental design}

A factorially arranged completely randomized design was used in this experiment. Samples from the surface 1 ayer $(0-15 \mathrm{~cm})$ of three soils from different areas in Saskatchewan (Table 3.2) were used as growth media. The treatments for Meota (Black Chernozemic) and Carrot River (Dark Gray Chernozemic) soil associations consisted of four levels of $\mathrm{P}\left(0,40,80\right.$ and $\left.160 \mathrm{mg} \mathrm{P} \mathrm{kg}^{-1}\right)$ and two levels of $\mathrm{Zn}(0$ and 
Table 3.2 Physical and chemical characteristics of the soil us ed.

\begin{tabular}{|c|c|c|c|}
\hline \multirow{2}{*}{ Characteristics } & \multicolumn{3}{|c|}{ Soils } \\
\hline & Sutherl and & Meota & Carrot River \\
\hline $\mathrm{pH}$ & 7.5 & 7.6 & 6.4 \\
\hline Inorganic carbon $\left(\mathrm{g} \mathrm{kg}^{-1}\right)$ & 1.0 & 0.9 & 0.1 \\
\hline Organic carbon $\left(\mathrm{g} \mathrm{kg}^{-1}\right)$ & 17.8 & 19.1 & $7 \cdot 7$ \\
\hline CEC (cmoles $\mathrm{kg}^{-1}$ ) & 41.6 & 12.2 & 5.7 \\
\hline Available $P\left(\mathrm{mg} \mathrm{kg}^{-1}\right)$ & 11.0 & 19.0 & 16.0 \\
\hline DTPA-Zn (mg kg $\left.{ }^{-1}\right)$ & 0.96 & 1.69 & 0.45 \\
\hline Sand $\left(\mathrm{g} \mathrm{kg}^{-1}\right)$ & 86 & 844 & 890 \\
\hline $\operatorname{Silt}\left(g \mathrm{~kg}^{-1}\right)$ & 336 & 88 & 65 \\
\hline $\operatorname{Clay}\left(8 \mathrm{~kg}^{-1}\right)$ & 579 & 68 & 45 \\
\hline Free $\mathrm{Fe}\left(\mathrm{g} \mathrm{Kg}^{-1}\right)$ & 8.7 & 4.8 & 4.5 \\
\hline Free $M n\left(\mathrm{~g} \mathrm{~kg}^{-1}\right)$ & 0.5 & 0.2 & 0.2 \\
\hline
\end{tabular}

$5 \mathrm{mg} \mathrm{Zn} \mathrm{kg}^{-1}$ ) in all possible combinations. For the sutherland soil (Dark Brown Chernozemic) association, the treatments consisted of all possible combinations of four levels of $P(0,40,80$ and $160 \mathrm{mg} P$ $\mathrm{kg}^{-1}$ ) and three I evels of $\mathrm{Zn}\left(0,5\right.$ and $\left.10 \mathrm{mg} \mathrm{zn} \mathrm{kg}^{-1}\right)$.

\subsubsection{Treatment application}

The soil samples used were air-dried at room temperature, ground with a wooden rolling pin and passed through a $2 \mathrm{~mm}$ polyethylene sieve. The treatments were applied to $4.5 \mathrm{~kg}$ (oven-dry basis) portions. Each kllogram of soil received a blanket application of other nutrients: $100 \mathrm{mg} \mathrm{N}, 200 \mathrm{mg} \mathrm{K}, 86 \mathrm{mg} \mathrm{Ca}, 5 \mathrm{mg} \mathrm{Mg}, 5 \mathrm{mg} \mathrm{s}, 5$ 
$\mathrm{mgFe}, 1 \mathrm{mg} \mathrm{Cu}, 4 \mathrm{mg} \mathrm{Mn,} 0.5 \mathrm{mg} \mathrm{B}$, and $0.6 \mathrm{mg}$ Mo according to TVA recommendations (Allen et al., 1976).

All $\mathrm{Zn}$ and $\mathrm{P}$ treatments were duplicated as ei ther radioisotope labelled $\left({ }^{65} \mathrm{Zn}\right.$ and $\left.{ }^{32} \mathrm{p}\right)$ or non-labelled and replicated four times. The Zn-labelled treatments corresponded with the $P$ non-labelled ones and vice versa.

Zinc as $2 \mathrm{nSO}_{4} \cdot 7 \mathrm{H}_{2} \mathrm{O}$ was applied at specific activities of 12 and $6 \mu \mathrm{Ci}{ }^{65} \mathrm{Zn} \mathrm{mg}^{-1}$ of ${ }^{64} \mathrm{Zn}$ for the 5 and $10 \mathrm{mg} \mathrm{zn} \mathrm{kg}^{-1}$ soil treatments, respectively. Phosphorus was applied in $\mathrm{KH}_{2} \mathrm{PO}_{4}$ form at specific activities of $1.88,0.94$ and $0.47 \mu \mathrm{Ci}{ }^{32} \mathrm{P} \mathrm{mg}^{-1}$ of ${ }^{31} \mathrm{P}$ for the 40,80 and $160 \mathrm{mg} \mathrm{P} \mathrm{kg}^{-1}$ soil treatments, respectively. All nutrients were applied in solution form to dry soil, the soil was allowed to air-dry and was subsequently mixed in a rotary tumbler for $2 \mathrm{~h}$. The treated soils were transferred to polyethylene pots in 1-kg (oven-dry basis) portions.

\subsubsection{Establishment of the experiment}

The potted soils were wetted to field capacity with deionized water and incubated for 7 days prior to seeding. Four seeds of beans (Phaseolus vulgaris cv. Pinto) were sown in each pot.

\subsubsection{Maintenance of the experiment}

Sixteen $h$ light and $8 \mathrm{~h}$ dark periods were used for the duration of the experiment at a constant temperature of $22+2{ }^{\circ} \mathrm{C}$. The pots were watered daily to near field capacity. Evaporation from the surface of the pots was reduced by placing a layer of "perlite" beads on the soil surface. After establishment the seedlings were thinned to two plants per pot. 


\subsubsection{Plant tissue sampling and analyses}

Plant tissue was sampled at two stages during the course of the experiment. Two of the four replications selected at random from each treatment but including two $2 n-l a b e l l e d$ and two $p$-labelied ones were harvested at $1 / 10$ bloom stage. The remaining two replicates were sampled at maturity. Roots, tops, grain and straw were separated and washed with deionized water. Plant samples were dried at $60^{\circ} \mathrm{C}$ and weighed. For mature samples, the total dry matter and grain yields were determined and straw yields were calculated by difference. Each replicate from each harvest was analyzed separately for total $P$ and $Z n$ and where applicable for ${ }^{32} \mathrm{P}$ and ${ }^{65} \mathrm{Zn}$ activity (Section 3.4.2).

\subsubsection{Statistical analysis}

All data were subjected to a two-way analysis of variance. Orthogonal polynomial and or contrasts were used to partition the sum of squares for $P$ and $Z$ n effects and interaction into single degree of freedom

\subsubsection{Effectiveness of zinc fertilizers}

Several $\mathrm{Zn}$ sources have been tested to correct $\mathrm{Zn}$ deficiency in crops (Anderson, 1964; Boawn, 1973; Gallagher et al., 1978). Zinc chelate, particularly ZnEDTA, has been the most frequently used to correct $\mathrm{Zn}$ deficiencies in field experiments. However, the relatively high cost of ZnEDTA has precluded its wi despread use. Consequently, forms such as $\mathrm{Zn}$ Iignosul phonates have also been considered. Since the relative effectiveness of various types of $\mathrm{zn}$ fertilizers has not been determined, two $\mathrm{Zn}$ lignosulphonates were compared directly with 
Zn suifate $\left(\mathrm{ZnSO}_{4}\right)$ and $\mathrm{Zn}$ EDTA (ZnEDTA). This was done by comparing dry matter yield and $z$ n uptake of a selected plant species in a growth chamber experiment.

Lignosul phonates are acid sulfite pulping by-products removed during the isolation of cellulose from wood. In Canada alone, some 2 $x 10^{6}$ tonnes of these by-products are produced annually, most of which are returned untreated to the environment. Currently, sulfite woodpulping operations are classified as either low-yield (LY, $0.4-0.5 \mathrm{~kg}$ $\mathrm{kg}^{-1}$ ), medium yield (MY, $0.5-0.6 \mathrm{~kg} \mathrm{~kg}^{-1}$ ), high yield (HY, $0.65-0.75$ $\mathrm{kg} \mathrm{kg}^{-1}$ ), or ultra-high (UHY, $0.76 \mathrm{~kg} \mathrm{~kg}^{-1}$ ) processes; the term "yield" refers to the quantity of cellulosic fibers obtained fron the wood source. A further subdivision can also be made depending upon the cationic species used (e.g. ammonium, sodium, magnesium or cal cium) in conjunction with suifurous acid.

In this investigation the 1 ignosulphonates used were from low-yield $\left(0.44 \mathrm{~kg} \mathrm{~kg}^{-1}\right)$ ammoni um-based and high-yield $\left(0.75 \mathrm{~kg} \mathrm{~kg}^{-1}\right)$ sodi um-based processes. The wood used in both cases was obtained from sof twoods (conifers). The corresponding zn-modified forms were then prepared, i.e. ZnLY and ZnHY, respectively. The chemical composition of these technical 1 ignosul phonates is shown in Table 3.3 .

\subsubsection{Experimental design}

Beans (Phaseolus vulgaris cv. Pinto) were used as a test crop and the surface soil sample $(0-15 \mathrm{~cm})$ obtained from a Regosolic very fine sandy loam was used as a growth medium (Table 3.4). In addition to the Regosolic very fine sandy loam, three other surface $(0-15 \mathrm{~cm})$ soil, namely a Chernozemic loamy very $f$ ine sand, a chernozemic loam 
Table 3.3 Chemical composition of zinclignosul phonates prepared from low-yi eld ammoni um based ( $Z n L Y$ ), and high-yield sodi um based (ZnHY) 1 ignosul phonates ${ }^{\dagger}$.

\begin{tabular}{|c|c|c|}
\hline & $\mathrm{g}_{\mathrm{kg}}^{\mathrm{ZnL}}$ & $\mathrm{g} \mathrm{kg}^{\mathrm{ZnH}}$ \\
\hline Lignosul phonate & 653.0 & 336.0 \\
\hline Total carbohydrate & 197.0 & 192.0 \\
\hline Nitrogen & 31.0 & 0.3 \\
\hline Phos phor us & 0.4 & 0.07 \\
\hline Ash & 1.0 & 23.8 \\
\hline Sulf ate & 40.7 & 11.1 \\
\hline Thi os ulf ate & 1.6 & 5.4 \\
\hline Sulfite & 68.3 & 169.0 \\
\hline $\operatorname{Zinc} c^{\varepsilon}$ & 50.0 & 50.0 \\
\hline \multicolumn{3}{|c|}{$\begin{array}{l}\text { Anal yses provided by Dr. N.G. Lewis, Pulp } \\
\text { and Paper Institute of Canada, Point Claire, } \\
\text { Quebec }\end{array}$} \\
\hline
\end{tabular}

and a Chernozemic silt loam were used in an incubation experiment (Table 3.4). All soils used were air-dried at room temperature, ground and sieved $(2 \mathrm{~mm})$.

Two experiments were conducted to assess various $\mathrm{Zn}$ sources, namely $\mathrm{ZnSO}_{4}$, ZnEDTA, Iow yield ammonium based $\mathrm{Zn-Iignosulphonate}$ ( $\mathrm{ZnLY}$ ), and high yield sodi um based Zn-lignosul phoante (ZnHY). In the first experiment, the treatments were established in $1.5 \mathrm{~L}$ polyethylene pots containing $1.0 \mathrm{~kg}$ of Regosolic very fine sandy loam. Zinc in organic forms was applied at a rate of $2.5 \mathrm{mg} \mathrm{kg}^{-1}$ of soil and 


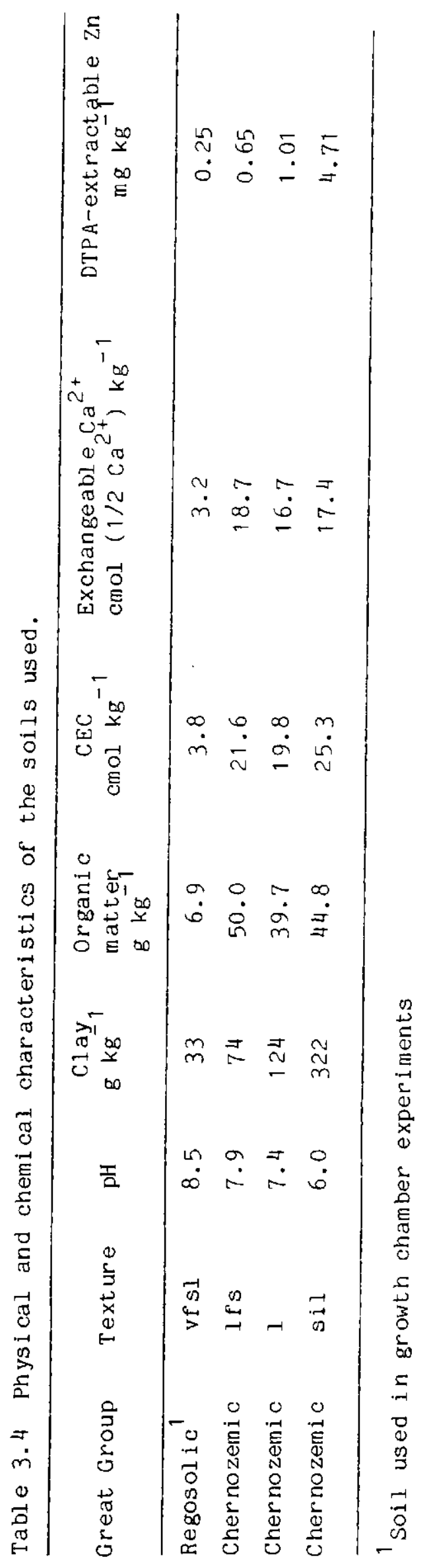


$\mathrm{ZnSO}_{4} \cdot 7 \mathrm{H}_{2} \mathrm{O}$ form at a rate of $5 \mathrm{mg} \mathrm{kg}{ }^{-1}$ of soil. Controls (no zinc added) were also established for each source as a matter of routine. Blanket application of other nutrients included $117 \mathrm{mg} \mathrm{N}, 40 \mathrm{mg}$ P, $133 \mathrm{mg} \mathrm{K}, 167 \mathrm{mg} \mathrm{Ca}, 5 \mathrm{mg} \mathrm{Mg,} 33 \mathrm{mg} \mathrm{S}, 5 \mathrm{mg} \mathrm{Fe,} 5 \mathrm{mg} \mathrm{Mg}, 0.5 \mathrm{mg} \mathrm{B}$, and $0.8 \mathrm{mg}$ Mo per $\mathrm{kg}$ of soil according to TVA recommendations (AlIen et al., 1976). The nutrients were applied to the surface of the potted soils in solution form and the soil was allowed to equilibrate for one week. All treatments were arranged in a completely randomized design with four replicates. Four seeds of bean were sown in each pot. The surface of the soils was kept damp by repeated application of water to the surface. After establishnent, the seedlings were thinned to two plants per pot. The pots were watered daily to field capacity with deionized water. During the growth period, the chamber was maintained at $20+2{ }^{\circ} \mathrm{C}$ with a $16 \mathrm{~h}$ photoperiod.

In the second experiment, only $\mathrm{ZnSO}_{4}$ and $\mathrm{ZnLY}$ treatrents were establ ished in $2 \mathrm{~L}$ polyethylene pots containing $1.5 \mathrm{~kg}$ of the same Regosolic very fine sandy loam soil. Zinc in both forms was applied at four rates $\left(0,0.5,2.5\right.$ and $5.0 \mathrm{mg} \mathrm{kg}^{-1}$ soil). Other nutrients were applied at the same rates used in the first experiment. This experiment was established in the same manner as the first experiment.

In a separate incubation experiment, $100 \mathrm{~g}$ samples of each of the four soils (Table 3.4) were treated with $10 \mathrm{mg} \mathrm{zn} \mathrm{kg}^{-1}$ of soil in the form of $\mathrm{ZnSO}_{4}$, ZnEDTA, ZnLY or ZnHY. Four replicates of each treatment were incubated at field capacity for 5 wh at a constant temperature of $25 \pm 1^{\circ} \mathrm{C}$. 


\subsubsection{Soil and plant tissue sampling and analyses}

Plants in both experiments were harvested at $1 / 10$ bloom stage. In the first experiment, the top three leaves were collected separately from the remaining shoot material. In addition, root material was removed manually from all pots of the first experiment and washed free of soil. Harvested plant material was processed and digested for total $2 n$ using the method outlined in section 3.4.2. Soil samples obtained at the completion of the experiments were analyzed for DTPA-extractable Zn (Section 3.4.1.7).

\subsubsection{Statistical analysis}

Analysis of variance were performed for a randomized complete design. Duncan's multiple range test was used to compare treatment mean effects.

\subsection{Distribution of Native and Applied Zinc}

The distribution of native $\mathrm{Zn}$ among different $\mathrm{Zn}$ forms was examined in the three soils used for $P X$ Zn experiment with beans (Section 3.2.3). To study the distribution of added $\mathrm{Zn}, 5 \mathrm{mg}{ }^{65} \mathrm{Zn}$ $\mathrm{kg}^{-1}$ with $0 \mathrm{mg}^{31} \mathrm{P} \mathrm{kg}^{-1}$ and $5 \mathrm{mg}^{65} \mathrm{zn} \mathrm{kg}^{-1}$ with $150 \mathrm{mg}^{31} \mathrm{p} \mathrm{kg}^{-1}$ treatments were selected from the same experiment. Soil samples were collected before seeding, after $1 / 10$ bloom stage harvest, and after harvesting the beans at maturity. The fractionation scheme is given in Figure 3.4 and the analytical methods involved are described in Sections 3.4 .1 .9 through 3.4 .1 .9 .7 . 


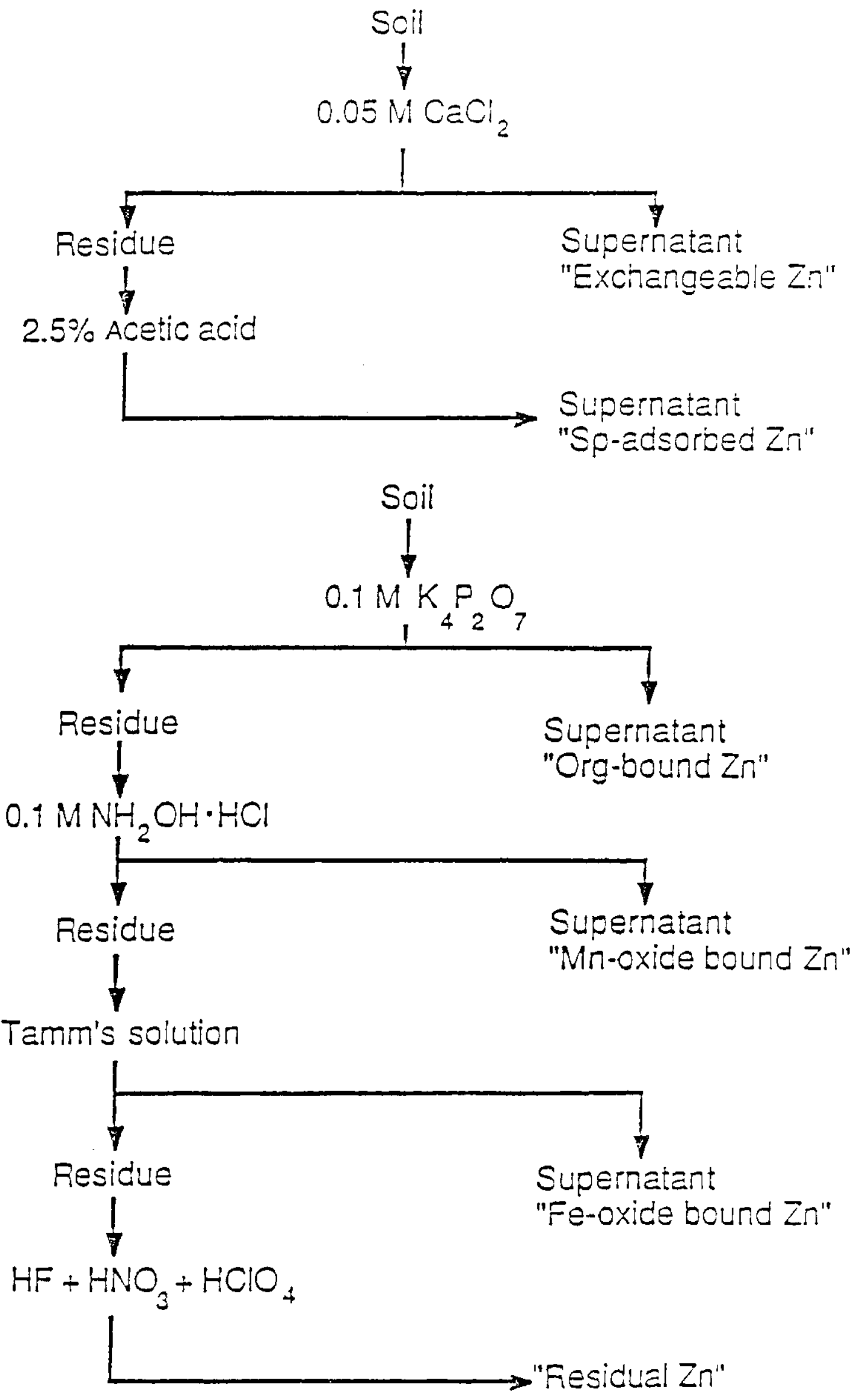

Figure 3.4 Fractionation procedure for native and applied $\mathrm{Zn}$. 


\section{4 Analytical Procedures}

3.4.1 Soil sample collection and preparation

Composite soil samples collected for soil analysis were air-

dried at room temperature, ground with a wooden rolling pin and passed through a $2 \mathrm{~mm}$ polyethylene sieve before analysis.

\subsubsection{1 pH and electrical conductivity}

Soil suspensions (1:1 soil:water ratio) were shaken for $30 \mathrm{~min}$ on a reciprocating shaker. The $\mathrm{pH}$ and electrical conductivity of the suspension were determined using standard pH and conductivity meters, respectively.

\subsubsection{Soil texture}

Particle size distribution was determined by the hydrometer method as outlined by Mckeague (1978). Samples were pretreated with sodium hexaphosphate and dispersed for 5 min in a Hamilton Beach blender. Corrections were made for organic matter content.

\subsubsection{Cation exchange capacity}

Soil cation exchange capacity was determined by leaching a $\mathrm{Ba}$ saturated soil sample with 1 M ammoniun acetate (Mckeague, 1978) and determining Ba by atomic absorption spectrophotometry.

\subsubsection{0.5 $\mathrm{M} \mathrm{NaHCO}_{3}$-extractable P}

$0.5 \mathrm{M} \mathrm{NaHCO}_{3}$ extractable-P was determined in a $1: 20$ soil to 0.5 $\mathrm{M} \mathrm{NaHCO}_{3}$ ( $\mathrm{pH} 8.5$ ) suspension by the method of olsen et al. (1954). 


\subsubsection{Resin extractable P}

Resin $P$ was extracted by the method as outlined by Hedley et al. (1982). $0.4 \mathrm{~g}$ resin (Dowex $1 \times 8-50,>319 \mu \mathrm{m}$, in bicarbonate form) in nylon bag and $30 \mathrm{ml}$ of deionized water were added to $0.5 \mathrm{~g}$ of soil in a $50 \mathrm{ml}$ centrifuge tube. After shaking the mixture for $16 \mathrm{~h}$, the resin bag was removed and then shaken overnight with $20 \mathrm{ml}$ of 0.5 $\mathrm{M} \mathrm{HCl}$. Phosphorus was determined on $10 \mathrm{ml}$ of extract using the reagents of Murphy and Ripley (1962).

\subsubsection{Inorganic and organic carbon}

Inorganic $C$ was determined by placing finely ground soil samples into a flask and adding $10 \mathrm{ml}$ of approximately $6 \mathrm{M} \mathrm{HCl}$ (Tiessen et al., 1983). After the initial reaction subsided, the flask was heated to bring the reaction mixture to a gentle boil for about $7 \mathrm{~min}$ and the evolved $\mathrm{CO}_{2}$ was collected in $0.15 \mathrm{M} \mathrm{NaOH}$ in an absorption tower and titrated between $\mathrm{pH} 8.3$ and 3.7 . Organic $\mathrm{C}$ was determined using the dry combustion method after carbonate removal (Tiessen et al., 1983).

\subsubsection{Available zinc}

A vailable $\mathrm{Zn}^{\circ}$ was extracted according to the method described by Lindsay and Norvell (1978). The DTPA extracting solution was prepared to contain $0.005 \mathrm{M}$ di ethylenetriaminepentaacetic acid (DTPA), $0.01 \mathrm{M}$ calci um chloride $\left(\mathrm{CaCl}_{2}\right)$, and $0.1 \mathrm{M}$ triethanolamine (TEA). The final solution was adjusted to $\mathrm{pH} 7.30+0.05$ with dilute $\mathrm{HCl}$. Ten $\mathrm{g}$ of airdry soil were placed into acid washed $125 \mathrm{ml}$ conical flask. Twenty $\mathrm{ml}$ of the DTPA extracting solution was added to the flask. The flasks 
were covered with parafilm and secured upright in a horizontal shaker with a stroke of $6 \mathrm{~cm}$ oscillating at 120 cycles $\mathrm{min}^{-1}$. The samples were shaken for $2 \mathrm{~h}$ and filtered by gravity through whatman $\$ 42$ filter paper into vials. Zinc in the filtrates was determined by atomic absorption spectrophotometry.

\subsubsection{Free $\mathrm{Fe}$ and $\mathrm{Mn}$}

Free $F e$ and $M n$ were determined by the method developed by De Endredy (1963) as modified by McLaren and Crawford (1973). One hundred $\mathrm{ml}$ of Tamm's solution $(0.1 \mathrm{M}$ oxalic acid and $0.175 \mathrm{M}$ ammonium oxalate, pH 3.25) were added to $2 \mathrm{~g}$ of soil in a $250 \mathrm{ml}$ beaker. The mixture was placed in a hot water bath $\left(100^{\circ} \mathrm{C}\right)$ for $2.5 \mathrm{~h}$. During extraction, the suspension was stirred intermittently with a glass rod, and the liquid level in the beaker was maintained near $100 \mathrm{ml}$ with deionized water. After extraction, the suspension was transferred into a $250-\mathrm{ml}$ centrifuge bottle with another $50 \mathrm{ml}$ of Tamm's solution reagent and centrifuged. After centrifugation, the Fe and Mn in the supernatant were determined by atomic absorption spectrophotometry.

\subsubsection{Zinc eractionation technique}

Zinc in different soil fractions was extracted using a modified version of the sequential fractionation scheme proposed for $\mathrm{Cu}$ by McLaren and Crawford (1973). The methods followed for the iractionation procedure were as follows: 
3.4.1.9.1 Exchangeable (non-specifically adsorbed) (EX)

Twenty grams of soil and $200 \mathrm{ml} 0.05 \mathrm{M} \mathrm{CaCl}_{2}$ were shaken in a 250-ml pol ycarbonate centrifuge bottle for $24 \mathrm{~h}$ and centrifuged.

\subsection{Exchangeable (specifically adsor bed) (ExAD)}

The soil residue from the EX extraction (Section 3.4.1.9.1) was washed twice with $100 \mathrm{ml}$ of deionized water and shaken with $200 \mathrm{ml}$ of $2.5 \%$ acetic acid for $24 \mathrm{~h}$ and centrifuged.

\subsection{Organically bound $\mathrm{Zn}$ (OM)}

This Zn fraction was determined on a second subsample of soil using the procedure described by Bascomb (1968). Two grams of soil were shaken with $200 \mathrm{ml}$ of $0.1 \mathrm{M} \mathrm{K}_{4} \mathrm{P}_{2} \mathrm{O}_{7}$ for $16 \mathrm{~h} \mathrm{in} \mathrm{a} \mathrm{250-mI} \mathrm{polycar-}$ bonate centrifuge bottle. Organically bound $\mathrm{Zn}$ was calculated as $\mathrm{Zn}$ in the supernatant minus the $2 n$ present in the previous two fractions (Section 3.4.1.9.1 and 3.4.1.9.2).

\subsection{Mn-oxi de bound $\mathrm{Zn}$ ( $\mathrm{MnOX}$ )}

The soil residue from OM extraction (Section 3.4 .1 .9 .3 ) was washed twice with $100 \mathrm{ml}$ of deionized water. Zinc occluded by oxides and hydroxides was determined following the methods of Chao (1972). A $100 \mathrm{mI}$ extracting solution $\left(0.1 \mathrm{M} \mathrm{NH}_{2} \mathrm{OH} \cdot \mathrm{HCl}\right.$ in $0.01 \mathrm{M} \mathrm{HNO}_{3}$, $\left.\mathrm{pH} 2\right)$ was added to the centrifuge bottle containing the soil residue after washing and the content shaken for $30 \mathrm{~min}$ and centrifuged.

\subsection{Fe-oxide bound $\mathrm{Zn}$ ( $F \in O X)$}

Residue from the MnOX extraction (Section 3.4.1.9.4) was washed 
twice with $100 \mathrm{ml}$ of deionized water and transferred into a 250-ml beaker with $100 \mathrm{ml}$ of Tanm's solution $(0.1 \mathrm{M}$ oxalic acid and $0.175 \mathrm{M}$ ammonium oxalate at $\mathrm{pH} 3.25)$. The mixture was placed in a hot water bath $\left(100^{\circ} \mathrm{C}\right)$ for $2.5 \mathrm{~h}$. The 1 iquid level was maintained during digestion with deionized water. After extraction, the suspension was transferred to a centrifuge bottle with another $50 \mathrm{ml}$ of Tamm's solution and centrifuged.

\subsection{Residual Zn (RES)}

Residue from the $F \in O X$ extraction (Section 3.4 .1 .9 .5 ) was washed twice with deionized water and three times with $0.5 \mathrm{M}\left(\mathrm{NH}_{4}\right)_{2} \mathrm{CO}_{3}$ to remove the oxalate. It was subsequently dried in a forced air oven at $110^{\circ} \mathrm{C}$ for $24 \mathrm{~h}$, and ground to pass a $150 \mu \mathrm{m}$ stainless steel sieve. A $0.5 \mathrm{~g}$ subsample was placed in a teflon beaker containing enough deionized water to cover the bottom. After adding $15 \mathrm{ml}$ concentrated $\mathrm{HF}$ and $10 \mathrm{ml}$ concentrated $\mathrm{HNO}_{3}$, the beaker was covered and allowed to stand for $2 \mathrm{~h}$. Two $\mathrm{ml}$ of concentrated $\mathrm{HClO}_{4}$ were added and the mixture heated on a hot plate at low temperature until the dense fumes of $\mathrm{HClO}_{4}$ subsided (to dryness). After cooling, the sides of the beaker were washed with a small quantity of deionized $\mathrm{H}_{2} \mathrm{O}$. The mixture was evaporated to dryness, the residue dissolved in $4 \mathrm{mI} \quad 1: 1$ $\mathrm{HCl}$, and then diluted to $10 \mathrm{ml}$ vol une with $1: 1 \mathrm{HCl}$.

\subsection{Total Zinc}

A sample of soil was ground to pass through a $150 \mu \mathrm{m}$ stainless steel sieve. A $0.5 \mathrm{~g}$ subsample was then added to a teflon beaker and treated as outlined in the residual $\mathrm{Zn}$ extraction (Section 3.4.1.9.5). 
3.4.1.9.8 Zinc determination in soil eractions

Total $\mathrm{Zn}$ in each fraction was determined by atomic absorption spectrophotonetry. To determine the activity of $65 \mathrm{Zn}$, one-ml of supernatant was counted with $10 \mathrm{ml}$ of scintillation cocktail (ready solv. TM) in scintillation vials using a Beckman Ls9000 liquid scintillation counter. The amounts of added $\mathrm{Zn}$ associated with each fraction were calculated as follows:

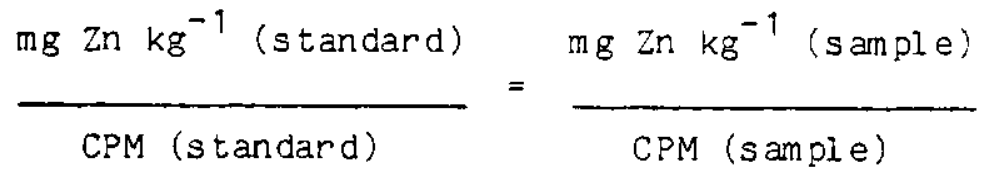

where $C P M=$ counts $\min ^{-1}$.

\subsubsection{Plant tissue analysis}

Harvested plant material was dried in a forced air oven at $60^{\circ} \mathrm{C}$ and ground to $425 \mu \mathrm{m}$ in a wiley mill prior to chemical analysis. Ground plant material was digested using a wet-ashing technique involving an acid mixture of $\mathrm{H}_{2} \mathrm{O}_{2}$ and $\mathrm{H}_{2} \mathrm{SO}_{4}$ described by Thomas et al. (1967). Zinc and $P$ concentration of plant material was determined using a Beckman spectrospan plasma arc emission spectrometer. To determine the activity of ${ }^{65} \mathrm{zn}$ and ${ }^{32} \mathrm{p}$, one $\mathrm{ml}$ of tissue digest was counted with $10 \mathrm{ml}$ of scintillation cocktail (ready solv. TM) in scintillation vials using a Beckman LS9000 liquid scintillation counter. The amounts of $P$ and $\mathrm{Zn}$ in plants derived from fertilizer sources were calculated from:

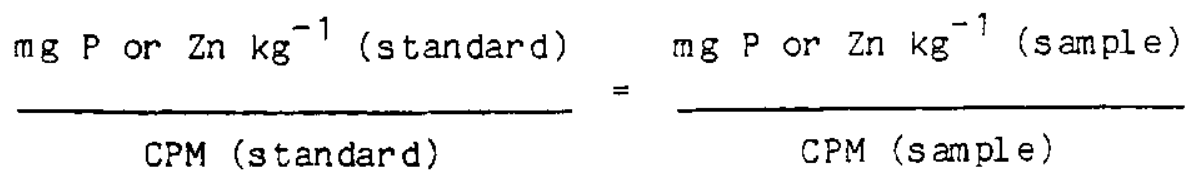


Percentage of plant $\mathrm{P}$ or 2 n derived from fertilizer (\% Pdff or $\%$ Zndff) was calculated using the relationship:

$$
\text { : } \mathrm{P} \text { or } \mathrm{Zndff}=\frac{{ }^{32} \mathrm{P} \text { or }{ }^{65} \mathrm{Zn} \text { in plant }}{\mathrm{P} \text { or } \mathrm{Zn} \text { total in plant }} \times 100 \quad[3.10]
$$




\section{RESULTS AND DISCUSSION}

\section{1 Spatial Variability of $\mathrm{Zn}$}

\subsubsection{Spatial variability of $\mathrm{Zn}$ in relation to other micronutrients in uniform topography}

The large spatial variation of DTPA-extractable micronutrients along the sampled transects is readily shown from the plots of extracted values versus distance on the transects (Figures 4.1 to 4.4).

A statistical summary of the micronutrient data ( $\mathrm{mg} \mathrm{kg}^{-1}$ ) obtained for the $A$ and $B$ horizons and total solum (calculated from $A$ and $B$ horizons) of both transects is given in Table 4.1.1. Coefficients of variation (CV) for all micronutrients (mg $\mathrm{kg}^{-1}$ ) in the cultivated soil were 1 arger in the $B$ than the $A$ horizon. The 1 argest $\mathrm{CV}$ in the cultivated A horizon was obtained for extractable Cu (32\%) and the lowest was obtained for $\mathrm{Fe}(22 \%)$. However, in the A horizon of the native prairie soil, the largest $C V$ was obtained for extractable $\mathrm{Fe}(43 \%)$. The CV's for the rest of the micronutrients in the A horizon of the native prairie soil were similar (36\%). A similar trend for iron was observed in the $B$ horizon as well. However, the patterns of the other three micronutrients in the $B$ horizons differed considerably from those in the A horizon.

Calculated mean micronutrient concentration values (mg kg-1) in the solum of the cultivated soil exhibited similar CV's to those of the A horizon but significantly lower than those of the $B$ horizon. In the native soil, the CV's for the $C u, M n$ and $F e$ in the solum were lower than those in either the A or $B$ horizons, but for $\mathrm{Zn}$ the $\mathrm{CV}$ was 


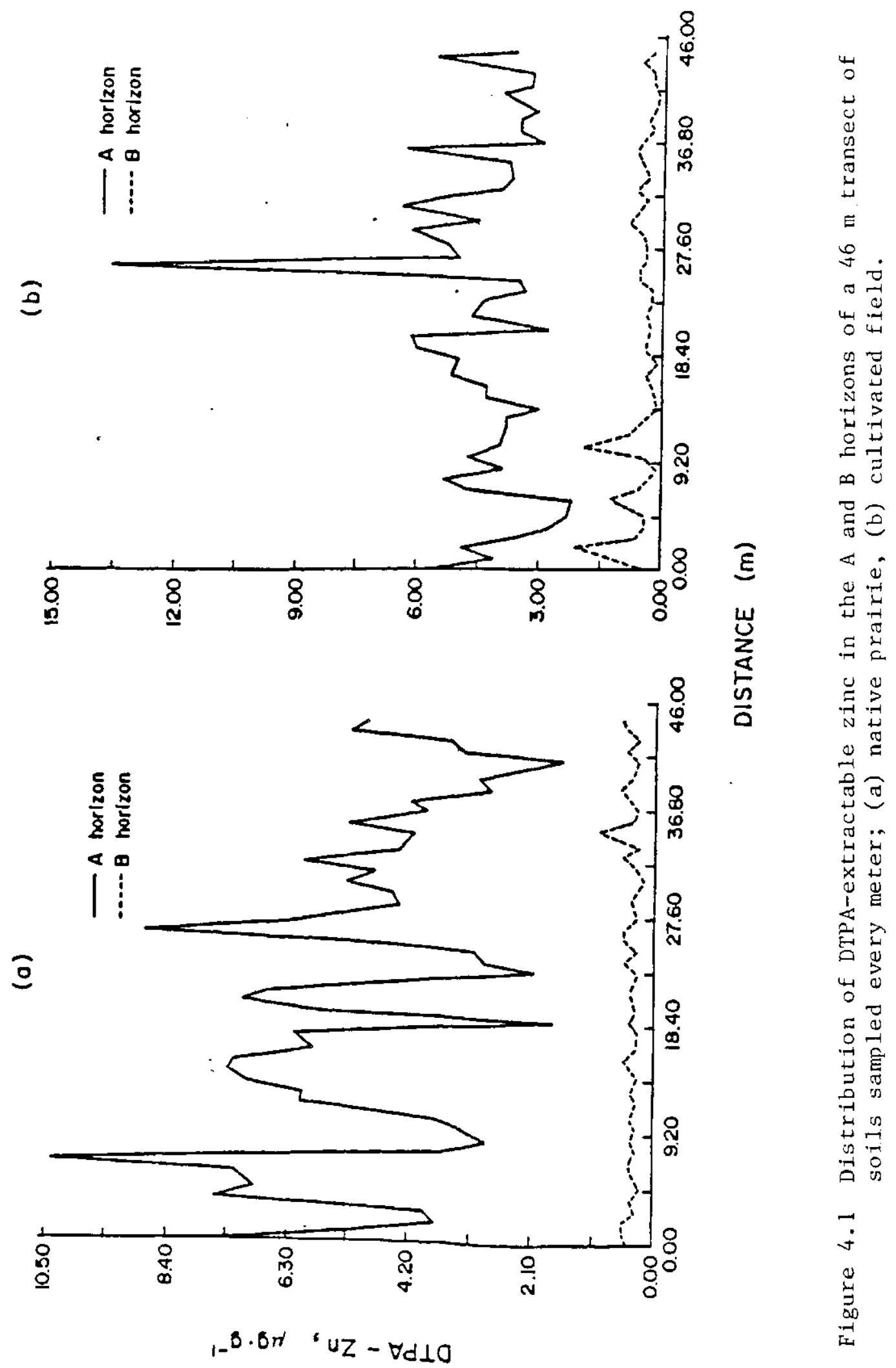




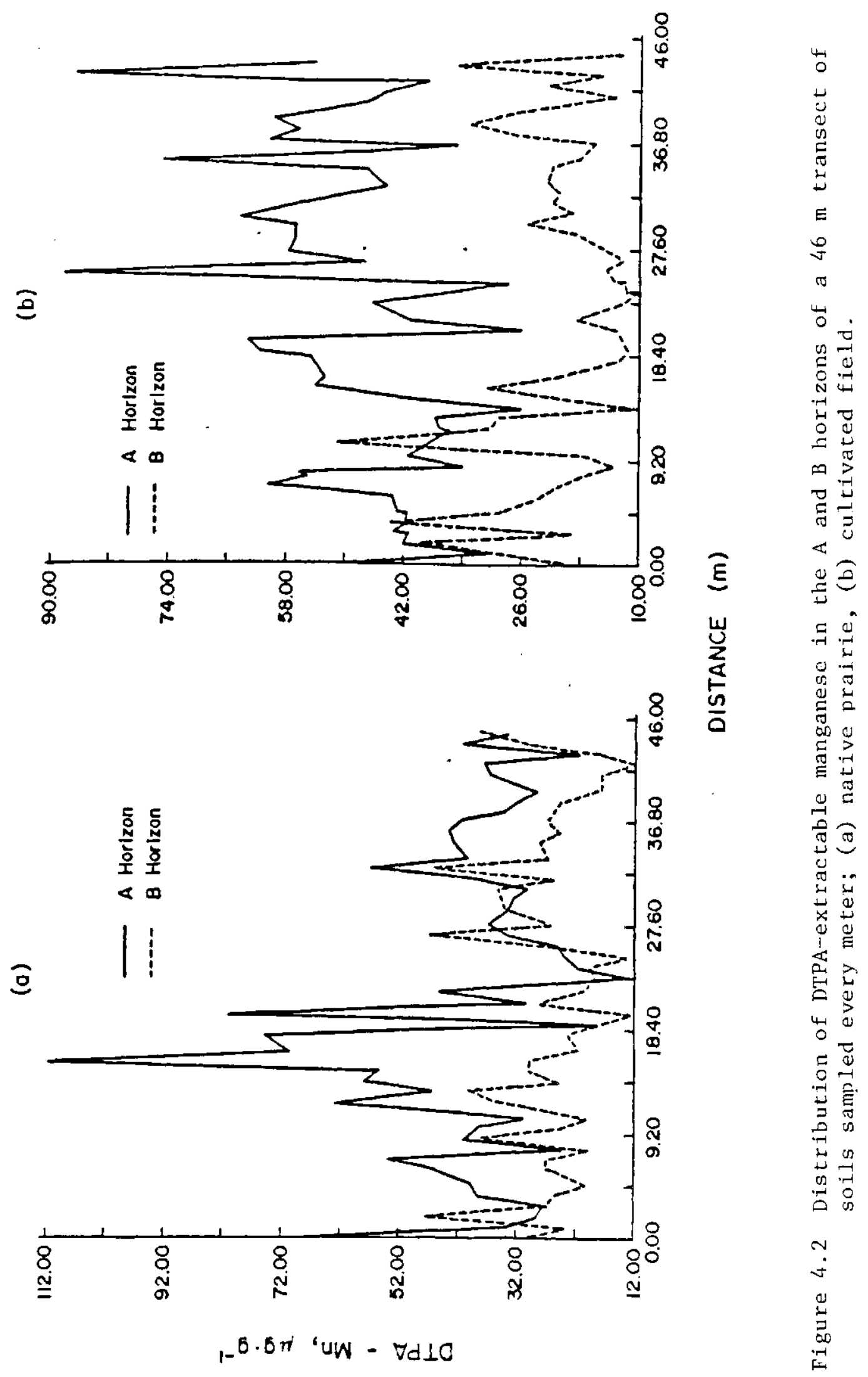




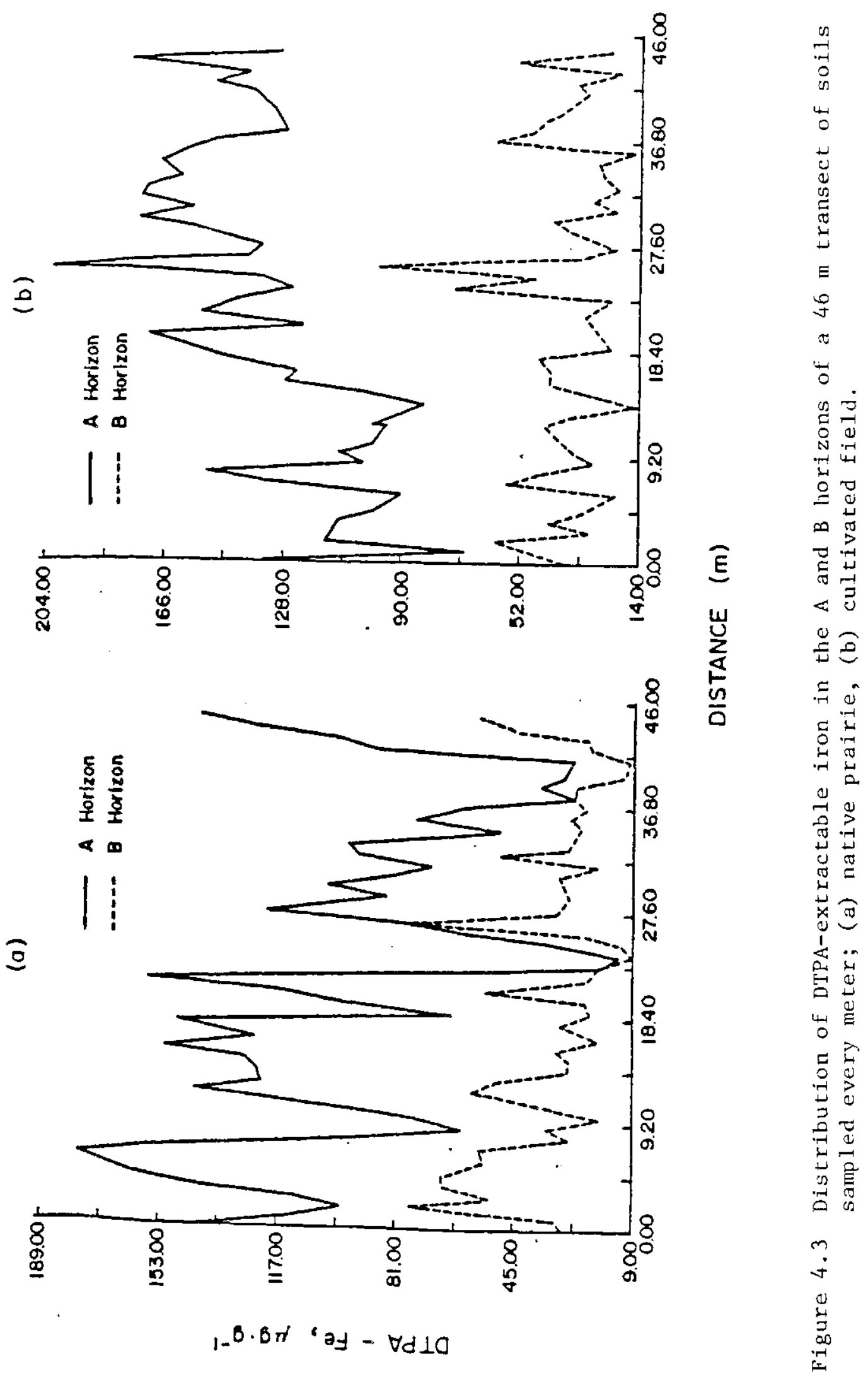




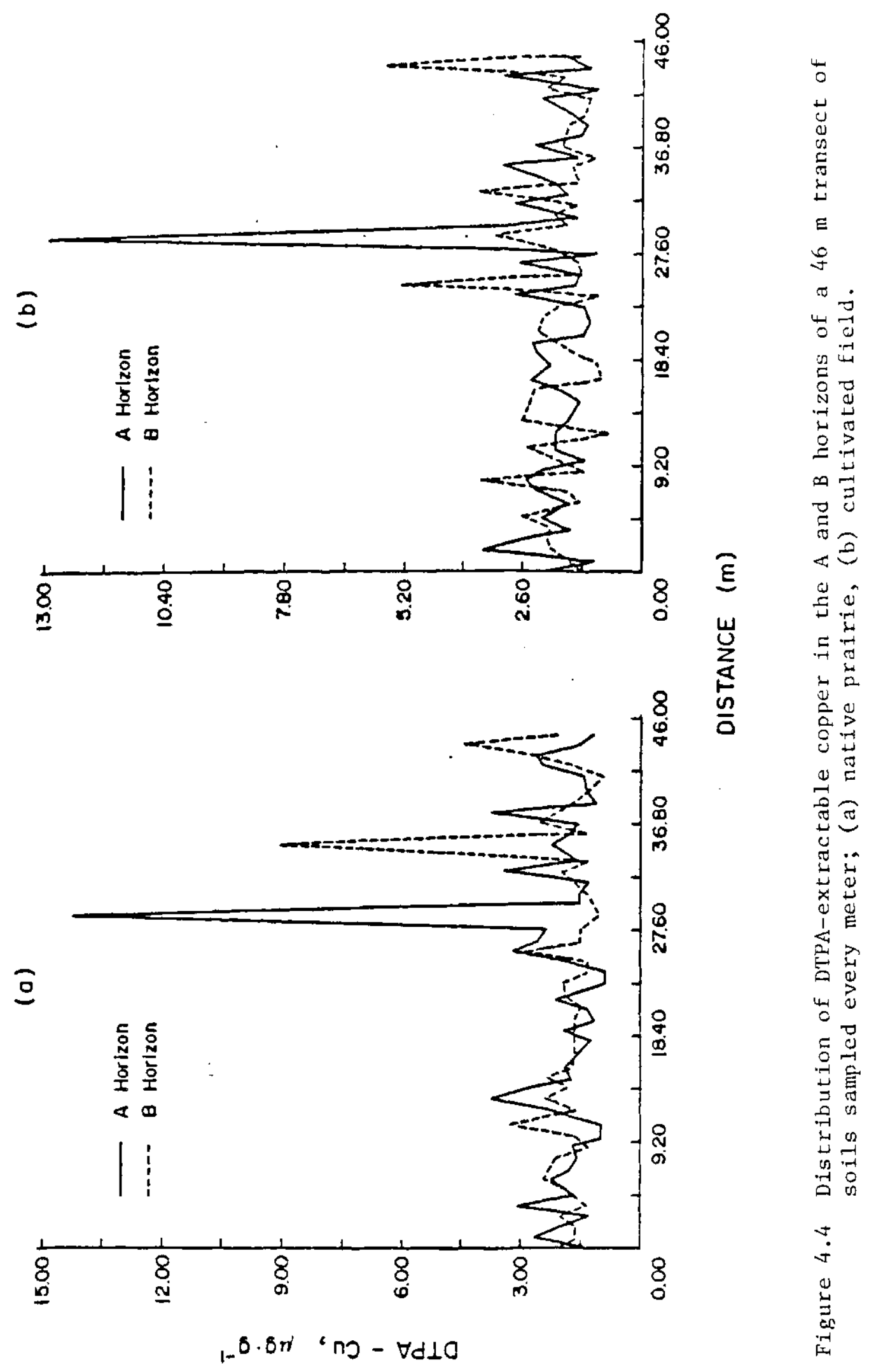


Table 4.1.1 Statistical summary for DTPA-extractable micronutrients in soils.

\begin{tabular}{|c|c|c|c|c|c|c|c|}
\hline \multirow[b]{2}{*}{ Micronutrient } & \multirow[b]{2}{*}{$\begin{array}{c}\text { Sample } \\
\text { No. }\end{array}$} & \multicolumn{3}{|c|}{ Cultivated $f i e l d$} & \multicolumn{3}{|c|}{ Native prairie } \\
\hline & & $\begin{array}{l}\text { Mean } \\
\mathrm{mg} \mathrm{kg}\end{array}$ & $\begin{array}{l}\text { SD } \\
\pm\end{array}$ & $\begin{array}{r}\mathrm{CV} \\
\%\end{array}$ & $\mathrm{mg} \mathrm{kg}^{-1}$ & $\begin{array}{l}\text { SD } \\
\pm\end{array}$ & CV \\
\hline \multicolumn{8}{|c|}{ A horizon } \\
\hline Copper & 46 & 1.94 & 0.63 & 32 & 1.91 & 0.70 & 37 \\
\hline Zine & 46 & 4.34 & 1.10 & 25 & 5.09 & 1.88 & 37 \\
\hline Manganese & 46 & 49.51 & 13.10 & 27 & 40.19 & 14.73 & 37 \\
\hline Iron & 46 & 134.51 & 29.23 & 22 & 96.47 & 41.84 & 43 \\
\hline \multicolumn{8}{|c|}{ B horizon } \\
\hline Copper & 43 & 1.92 & 0.88 & 46 & 1.87 & 0.67 & 36 \\
\hline Zine & 43 & 0.47 & 0.23 & 49 & 0.39 & 0.10 & 26 \\
\hline Manganese & 43 & 20.87 & 8.73 & 42 & 25.55 & 7.85 & 31 \\
\hline Iron & 43 & 35.81 & 13.55 & 38 & 33.36 & 15.16 & 45 \\
\hline \multicolumn{8}{|c|}{ Solum } \\
\hline Copper & 43 & 1.84 & 0.48 & 26 & 1.83 & 0.46 & 25 \\
\hline $\operatorname{Zinc}$ & 43 & 2.04 & 0.63 & 31 & 2.14 & 0.72 & 34 \\
\hline Manganese & 43 & 32.81 & 7.98 & 24 & 31.27 & 8.53 & 27 \\
\hline Iron & 43 & 77.39 & 17.53 & 23 & 58.35 & $2 i \cdot 9 i$ & 38 \\
\hline
\end{tabular}

lower only in the $B$ horizon.

The CV values were used to compare variability of micronutrients between cultivated and native prairie transects. The comparison was done with a t-test. The variance associated with each $\mathrm{CV}$ was calculated from the formula:

$$
S_{C V}^{2}=\left[\left(C V^{2}\right) / 2 N\right]\left[1+2(C V / 100)^{2}\right]
$$

where $\mathrm{N}$ is sample size (Sokal and Rohlf, 1969). 
A direct comparison of the two adjacent transects reveals that spatial variation of DTPA-extractable micronutrients (mg $\mathrm{kg}^{-1}$ ) was greater in the A horizon of the native prairie soil than in the cultvated one. In contrast, the spatial variation of $\mathrm{Cu}, \mathrm{Zn}$ and $\mathrm{Mn}$ in the $B$ horizon was 1 arger under cultivated conditions. The change of variability patterns under cultivation may in part be attributed to the redistribution of soil organic matter and clay within the soil profile. A significant $(P<0.01)$ positive relationship was found between soil organic matter and both $\mathrm{Zn}$ and $\mathrm{Mn}$ under both systems examined (Table 4.1.2). However, significant spatial redistribution of surface soil due to tillage translocation has occurred during the initial years of cultivation (Kachanoski, 1984), which would also tend to reduce local differences in concentration values at the surface. A significant positive correlation between $\mathrm{Cu}$ and organic carbon was obtained only for the A horizon of the native prairie soil whereas no correlation existed between $\mathrm{Fe}$ and organic carbon (Table 4.1.2). However, there was a significant negative correlation between $F e$ and the bulk density of the cultivated soil B horizon (Table 4.1.2). There was no relationship between horizon thickness in the cultivated field and the concentration of $\mathrm{Cu}, \mathrm{Zn}$ and $\mathrm{Mn}$ (Table 4.1.2), which implies that these nutrients were homogeneously distributed in each of the two horizons sampled. However, approximately $15 \%$ of the variation in $\mathrm{Fe}$ concentration in the $\mathrm{A}$ horizon could be attributed to variation in the thickness of this horizon. The organic carbon content in the A horizon of both cultivated and native prairie soils was significantly but inversely correlated with the thickness of the horizon sampled (Kachanoski, 1984). Thus, higher concentrations of 
Table 4.1.2 Correlation coefficients among micronutrients (mg $\mathrm{kg}^{-1}$ ) and organic carbon $\left(\mathrm{g} \mathrm{kg}^{-1}\right)$, bulk density $\left(\mathrm{kg} \mathrm{m}^{-3}\right)$ and depth $(\mathrm{cm})$ of soil horizon sampled.

\begin{tabular}{|c|c|c|c|c|c|c|}
\hline \multirow{2}{*}{$\frac{\text { Mi cronutrient }}{\text { Horizon }}$} & \multicolumn{2}{|c|}{ Organic Carbon } & \multicolumn{2}{|c|}{ Bulk density } & \multicolumn{2}{|c|}{ Thickness } \\
\hline & A & $\mathrm{B}$ & A & 8 & A & $B$ \\
\hline \multicolumn{7}{|c|}{ Native prairie } \\
\hline $\mathrm{Cu}$ & $0.38^{* *}$ & 0.11 & -0.24 & 0.09 & $-0.35^{*}$ & -0.25 \\
\hline $\mathrm{Zn}$ & $0.66^{* *}$ & 0.12 & $-0.35^{*}$ & $-0.31^{*}$ & $-0.47^{* *}$ & -0.28 \\
\hline$M n$ & $0.31^{*}$ & $0.37^{*}$ & $-0.30^{*}$ & -0.25 & $-0.31^{*}$ & -0.03 \\
\hline $\mathrm{Fe}$ & 0.26 & 0.27 & -0.04 & 0.11 & $0.38^{* *}$ & $0.33^{*}$ \\
\hline \multicolumn{7}{|c|}{ Cultivated } \\
\hline $\mathrm{Cu}$ & -0.22 & -0.17 & -0.29 & -0.05 & -0.11 & -0.04 \\
\hline $\mathrm{Zn}$ & $0.45^{* *}$ & $0.41^{* *}$ & -0.20 & $-0.32^{*}$ & -0.04 & 0.27 \\
\hline$M n$ & 0.29 & $0.62^{* *}$ & -0.09 & $-0.34^{*}$ & 0.02 & -0.12 \\
\hline $\mathrm{Fe}$ & -0.05 & 0.19 & -0.10 & $-0.35^{*}$ & $0.38^{*}$ & 0.04 \\
\hline
\end{tabular}

organic carbon were associated with less soil mass in the A horizon. This is probably associated with the mode of deposition of organic litter in the upper few centimeters of the soil. The micronutrients that exhibited significant positive correlation with organic $c$ content in the A horizon of the native prairie soil also exhibited significant but inverse correlation with A horizon thickness (Table 4.1.2). This would also imply association of those micronutrients with organic matter and, thereby, partial dependence of their variation on the variation of organic carbon in the A horizon. However, this dependence as far as distribution is concerned, appears to have been disturbed under cultivation. No significant correlation was found 
between $B$ horizon thickness and organic carbon concentration (Kachanoski, 1984) or $\mathrm{Cu}, \mathrm{Mn}$ and $\mathrm{Zn}$ concentrations.

The mean content ( $m \mathrm{~g} \mathrm{~kg}^{-1}$ ) of $\mathrm{Zn}, \mathrm{Mn}$ and $\mathrm{E} e$ was higher in the $\mathrm{A}$ than in the $B$ horizon, under both native prairie and cultivated conditions (Table 4.1.1). This trend has also been reported for $\mathrm{Zn}$ in various soils of the province of Saskatchewan by stewart and Tanir (1971). The mean concentration of $\mathrm{Cu}$ in both horizons under both conditions was similar.

Another feature in Table 4.1 .1 is the association of 1 arger CV's with lower mean values of DTPA-extractable micronutrients. This is of extreme importance as an increased number of sampling cores would be required to obtain an estimated mean value as deficiency Iimits are approached.

The number of samples required to achieve $95 \%$ confidence 1 imits for a range about the mean value of $\pm 5, \pm 10$ and $\pm 20 \%$ for $\mathrm{Cu}$, $\mathrm{Zn}$, Mn and $\mathrm{Fe}$ are given in Table 4.1.3. As standard procedures for soil testing involve taking samples at constant depth (usually $0-15 \mathrm{~cm}$ ) and since there was no correlation between $\mathrm{Cu}, \mathrm{Zn}$ and $\mathrm{Mn}$ concentration and depth in the cultivated soil (Table 4.1.2), the concentration of these micronutrients was calculated for the $0-15 \mathrm{~cm}$ depth, assuming that they are homogeneously distributed in each horizon. The number of samples required for constant depth sampling are given in Table 4.1.4. The results in Tables 4.1 .3 and 4.1 .4 reveal large differences among the number of samples required for each micronutrient in order to obtain estimates with the same degree of precision. Thus, the number of samples must vary depending on the micronutrient to be evaluated. Conversely, if the same number of samples is used for determination of 


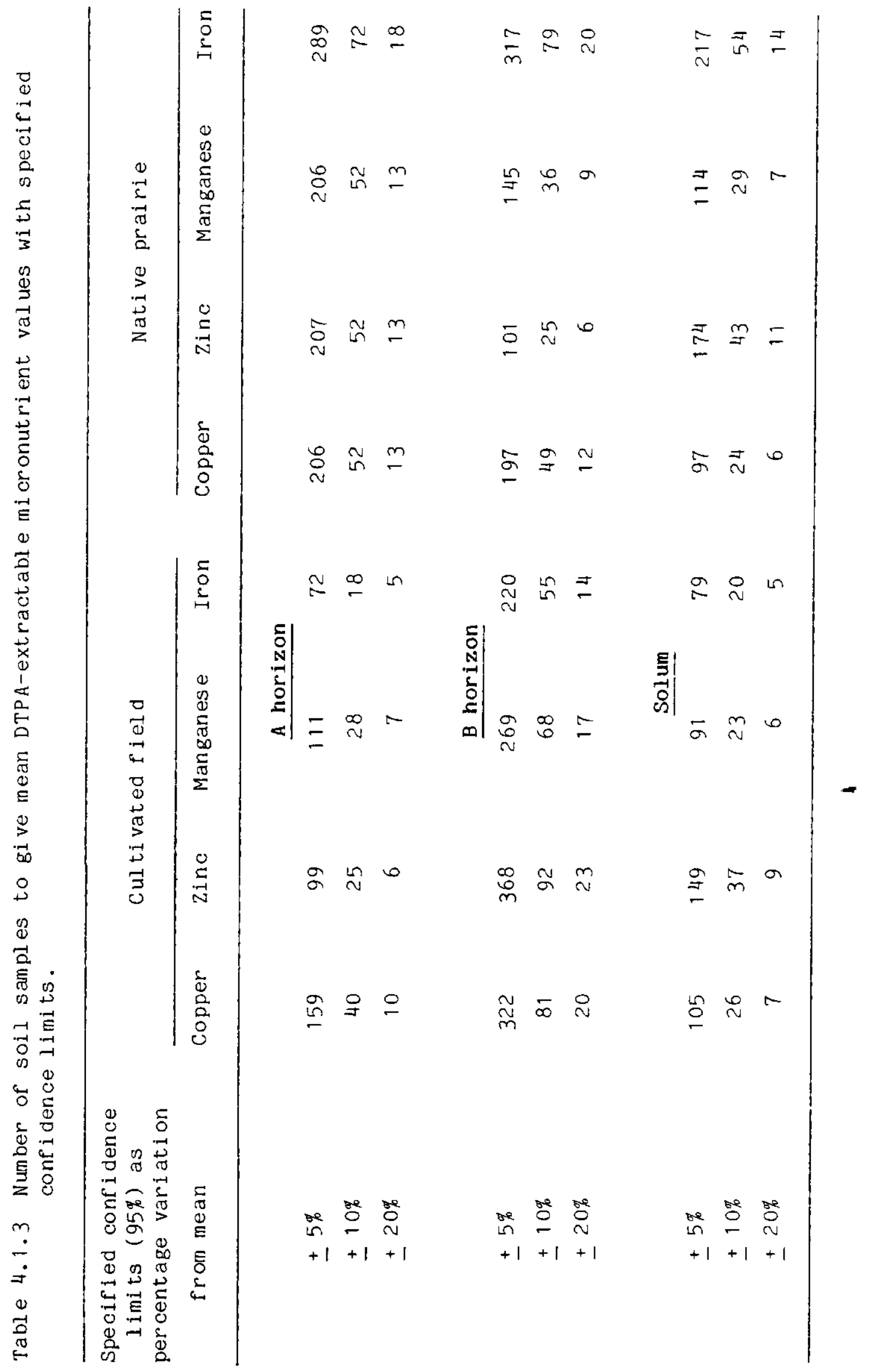




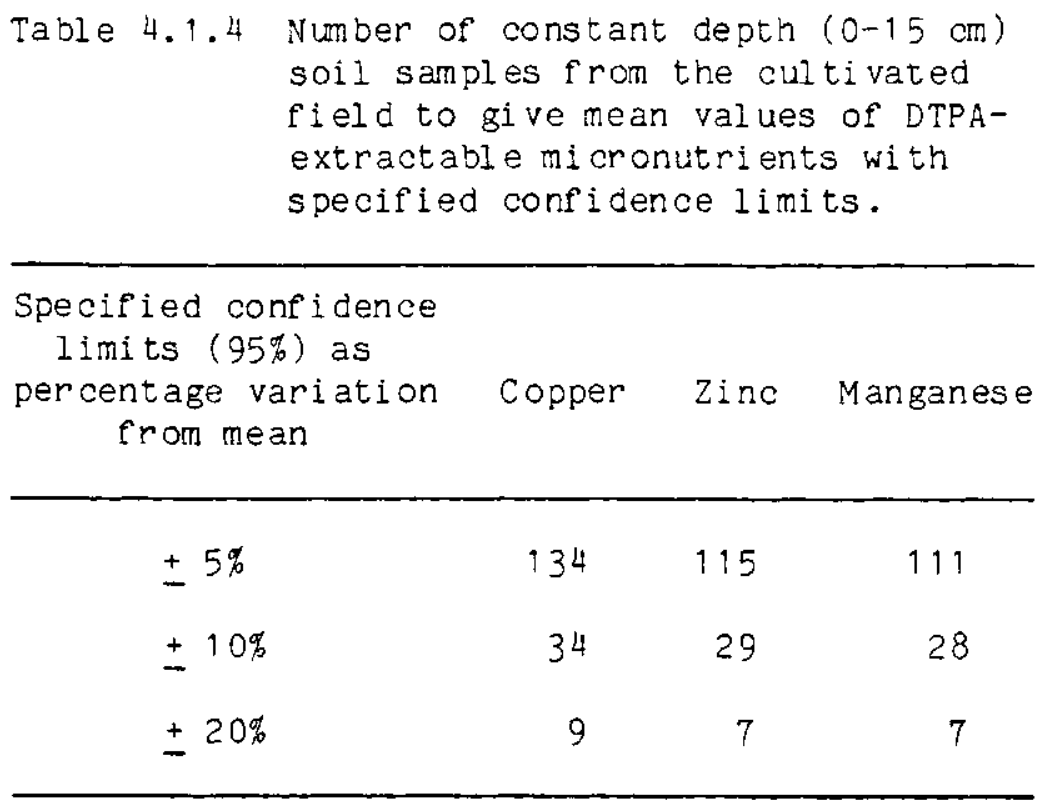

al1 DTPA-extractable micronutrients the results for each micronutrient will be at different level of precision. The need for varying sample size according to the micronutrient under investigation has also been documented by Khan and Nortcliff (1982). Hence, it is important the the desired level of precision be determined prior to field sampling. For example, five samples are required to obtain a DTPA-extractable Fe value with no more than $20 \%$ variation from the true mean (Table 4.1.3). However, if no more than 5\% variation is desirable, the sample size must be increased to 72 (Table 4.1.3). Calculation of Cu, $\mathrm{Zn}$ and $\mathrm{Mn}$ concentrations on a constant depth basis had virtually no effect on the number of samples required to obtain a true mean value for these mi cronutrients.

A statistical summary of the "total" DTPA-extractable micronutrients for the $\mathrm{A}$ and $\mathrm{B}$ horizons and total solum are given in $\mathrm{Table}$ 4.1.5. "Total" here refers to the content of extractaile micronutrients in the total mass of each horizon or the solum. If 
Table 4.1.5 Statistical summary for the "total" DTPA-extractable micronutrients in soils.

\begin{tabular}{|c|c|c|c|c|c|c|c|}
\hline \multirow[b]{2}{*}{ Mi cronutrient } & \multirow{2}{*}{$\begin{array}{c}\text { Sample } \\
\text { size } \\
\text { No. }\end{array}$} & \multicolumn{3}{|c|}{ Cul tivated $f i e l d$} & \multicolumn{3}{|c|}{ Native prairie } \\
\hline & & $\begin{array}{l}\text { Mean } \\
8 \mathrm{~m}^{-2}\end{array}$ & $\begin{array}{l}\text { SD } \\
\pm\end{array}$ & $\begin{array}{l}\mathrm{CV} \\
\%\end{array}$ & $\begin{array}{l}\text { Mean } \\
\mathrm{g} \mathrm{m}^{-2}\end{array}$ & $\begin{array}{l}\mathrm{SD} \\
\pm\end{array}$ & $\begin{array}{l}\mathrm{CV} \\
\text { of }\end{array}$ \\
\hline
\end{tabular}

\begin{tabular}{lrrrrrrr} 
& \multicolumn{7}{c}{ A horizon } \\
Copper & 46 & 0.49 & 0.26 & 53 & 0.36 & 0.16 & 43 \\
Zinc & 46 & 1.17 & 0.67 & 58 & 0.94 & 0.30 & 32 \\
Manganese & 46 & 13.10 & 6.81 & 52 & 7.72 & 2.90 & 38 \\
Iron & 46 & 37.24 & 20.15 & 54 & 18.69 & 8.23 & 44
\end{tabular}

\section{B horizon}

$\begin{array}{lrrrrrrr}\text { Copper } & 43 & 0.61 & 0.28 & 46 & 0.57 & 0.23 & 41 \\ \text { Zinc } & 43 & 0.16 & 0.10 & 61 & 0.12 & 0.05 & 37 \\ \text { Manganese } & 43 & 7.18 & 3.34 & 47 & 8.05 & 3.84 & 48 \\ \text { Iron } & 43 & 11.91 & 5.40 & 45 & 11.16 & 7.72 & 69\end{array}$

\section{Solum}

\begin{tabular}{lrrrrrrr} 
Copper & 43 & 1.11 & 0.38 & 34 & 0.93 & 0.28 & 30 \\
Zinc & 43 & 1.33 & 0.71 & 53 & 1.06 & 0.32 & 30 \\
Manganese & 43 & 20.28 & 7.34 & 36 & 15.77 & 4.36 & 28 \\
Iron & 43 & 49.14 & 20.30 & 41 & 29.85 & 12.97 & 43 \\
\hline
\end{tabular}

assessment of the micronutrient status of a field were to be based on the "total" amounts of micronutrients in the soil, a considerably larger number of samples would be required under cultivated conditions. However, under native conditions, the variability in the "total" amounts was of the same magnitude as for micronutrient concentration.

An important application of the variability information is in 
the design of an efficient sampling plan. Peck and Melstead (1967) discussed the desirability of an accurate knowiedge of soil variability in determining fertilizer requirement. If the variation is very large, a considerable portion of a field may remain deficient in a nutrient even though the extracted mean nutrient value may appear above critical levels of deficiency. Conversely, considerable portions of a field may contain adequate levels of a nutrient, in spite of a mean value indicating deficiency, thus resulting in waste of fertilizer. An.illustration of the above can be offered by assuming that the $B$ horizon of the cultivated soil is the medium for growth of a field crop. The mean $z$ n content in this horizon is 0.47 $\mathrm{mg} \mathrm{kg}^{-1}$, which is just below the critical level of $0.5 \mathrm{mg} \mathrm{kg}^{-1}$ used by the Saskatchewan Soil Testing Laboratory for a variety of crops. If a $5 \%$ precision with $95 \%$ confidence limit is required (i.e. $\pm 0.01 \mathrm{mg}$ $\mathrm{kg}^{-1}$ of DTPA-extractable $\left.\mathrm{Zn}\right), 368$ samples will be required. However, if the common practice of obtaining 12 samples is followed, the mean will have only a $\pm 28 \%$ level of precision, i.e. $0.47 \pm 0.13 \mathrm{mg} \mathrm{kg}^{-1}$ and could represent either deficient or sufficient levels of 2 n in soil.

The large sample number suggested in this study to obtain estimates of micronutrient spatial variation may never be practical. However, knowledge of this variation is essential to properly interpret soil tests as well as results of field experimentation. The use of composite samples, which is the normally recommended procedure, can provide mean DTPA-extractable micronutrient levels, but offers no indication of spatial variation within the field. The latter is of great importance in the case of micronutrients as sufficiency and deficiency criteria of ten lie within narrow limits. 
Statistical methods applied in this study to evaluate the spatial distribution of DTPA-extractable micronutrients are based on the assumption that the observations of a given variate are statistically independent regardless of their spatial position. However, this approach neglects the spatial correlation structure inherent in natural soils. Therefore, semivariograms were computed (Eq. 3.7, Section 3.1 .4 .2$)$ to analyze structure of all the micronutrients in the $A$ and $B$ horizon of native and prairie soils. All the micronturients were found to be randomly distributed, with the semivariograms showing no spatial dependence.

\subsubsection{Spatial variability of $\mathrm{Zn}$ in undulating topography}

The means, standard deviations, and coefficients of variation of DTPA-extractable soil $\mathrm{Zn}$ levels as well as $\mathrm{Zn}$ tissue concentration at FEEKES 10 growth stage for all the four transects are summarized in Table 4.1.6. Analysis for skewness and kurtosis was performed on all data to test the hypothesis that a given set of observations has been drawn from a population with normal distribution. The results of the

Table 4.1.6 Statistical summary for DTPA-extractable soil $\mathrm{Zn}$ levels and tissue $\mathrm{Zn}$ concentration at FEEKES 10 growth stage.

\begin{tabular}{|c|c|c|c|c|c|c|c|}
\hline \multirow[b]{2}{*}{ Transect } & \multirow[b]{2}{*}{$\begin{array}{c}\text { Sample } \\
\text { No. }\end{array}$} & \multicolumn{3}{|c|}{ DTPA-extractable $\mathrm{Zn}$} & \multicolumn{3}{|c|}{ Tissue $\mathrm{Zn}$ conc. } \\
\hline & & $\begin{array}{l}\text { Mean } \\
\text { mg kg }\end{array}$ & $\begin{array}{l}\text { SD } \\
\pm\end{array}$ & $\begin{array}{l}\mathrm{CV} \\
\%\end{array}$ & $\frac{\text { Mean }}{\operatorname{mg~kg}}$ & $\begin{array}{l}S D \\
\pm\end{array}$ & $\begin{array}{l}\mathrm{CV} \\
\%\end{array}$ \\
\hline$A$ & 50 & 0.56 & 0.33 & 59 & 12.3 & 4.2 & 35 \\
\hline $\mathrm{B}$ & 50 & 0.65 & 0.22 & 34 & 16.6 & 3.6 & 22 \\
\hline C & 50 & $3 \cdot 51$ & 0.62 & 18 & 37.9 & 5.2 & 14 \\
\hline $\mathrm{D}$ & 50 & 1.01 & 0.77 & 76 & 19.3 & 8.1 & 42 \\
\hline
\end{tabular}


analysis indicated insignificant amount of skewness and kurtosis, therefore, normal distribution was assimed. The importance of number of samples required to obtain a given precision with specific probability in level area has been discussed in detail (Section 4.1.1.). The number of samples required to estimate the mean of DTPA-extractable soil $\mathrm{Zn}$ levels and $\mathrm{Zn}$ tissue concentration with a specific probability at a given level of precision is given in Tabie 4.1.7. Similarly to the uniform topography field, a large number of samples were required to estimate DTPA-extractable soil Zn levels within 5, 10 and $20 \%$ of mean at the $95 \%$ conf idence 1 evel.

As mentioned in section $4.1 .1, \mathrm{CV}$ values with the help of the t-test can be used to compare the variability of the same parameter

Table 4.1.7 Number of samples to give mean DTPAextractable soil $\mathrm{Zn}$ levels and tissue $\mathrm{Zn}$ concentration at FEEKES 10 growth stage with specified confidence limits.

\begin{tabular}{|c|c|c|c|c|c|}
\hline \multirow{2}{*}{\multicolumn{2}{|c|}{$\begin{array}{l}\text { Specified confidence } \\
\text { limits }(95 \%) \text { as } \\
\text { percentage variation } \\
\text { from mean }\end{array}$}} & \multicolumn{4}{|c|}{ Transects } \\
\hline & & A & $B$ & $\mathrm{C}$ & D \\
\hline \multicolumn{6}{|c|}{ DTPA-extractable $\mathrm{Zn}$} \\
\hline $\pm 5 \%$ & & 560 & 185 & 50 & 913 \\
\hline $\pm 10 \%$ & & 140 & 46 & 13 & 228 \\
\hline $\pm 20 \%$ & & 35 & 12 & 3 & 57 \\
\hline \multicolumn{6}{|c|}{ Tissue $\mathrm{Zn}$ concentration } \\
\hline $\pm 5 \%$ & & 192 & 77 & 31 & 277 \\
\hline$+10 \%$ & & 48 & 19 & 8 & 69 \\
\hline $\pm 20 \%$ & & 12 & 5 & 2 & 16 \\
\hline
\end{tabular}


between either fields or mapping units. The same test can be used to compare two properties within a field. Equation 4.1 (Section 4.1.1) was used to compare the variability of DTPA-extractable soil zn with that of tissue Zn concentration of a particular transect. Results of the $t$-test analysis for each transect indicated that DTPA-extractable soil $\mathrm{Zn}$ exhibited greater variability compared to tissue $\mathrm{Zn}$ concentration. This conclusion is supported by the smaller number of samples required to estimate the mean of tissue $\mathrm{Zn}$ concentration compared to that of soil $\mathrm{Zn}$ levels (Table 4.1.7). One would have expected that the variability of tissue $\mathrm{Zn}$ concentration is equal to or greater than that of DTPA-extractable soil Zn levels, since plant Zn uptake depends on other factors in addition to available soil $\mathrm{Zn}$. However, since a great deal of variation can be avoided if specific plant parts or the whole plant is sampled at the same physiological stage (Bates, 1971), the smaller variability of tissue $\mathrm{Zn}$ concentration may be the result of the sampling procedure.

To examine whether there was a spatial dependence of DTPAextractable soil $\mathrm{Zn}$ levels and tissue $\mathrm{Zn}$ concentration semi variograms were drawn (Eq. 3.7, section 3.1.4.2) for transects A, B and C (Section 3.1.2). Since a semivariogram is only valid from about a half to about a third of the total sampling length (Journel and Huijbregts, 1978) semivariograms were computed only up to a lag of 25 m. Computation of semivariograms requires that the data should be stationary (Journel and Huijbregts, 1978), i.e. the expected value $E[Z(x)]$ of a random variable $Z(x)$ is constant and the covariance for each pair of random variable $[z(x), z(x+h)]$ is the same all over the field of interest and depends on distance $(h)$. DTPA-extractable $z n$ in 
transect $D$ increased from 0.2 in the knoll position to $3.04 \mathrm{mg} \mathrm{kg}^{-1}$ at the depression and did not fulfill the requirement of data stationarity. Similarly the tissue $Z$ n concentration ranged from 8.4 in the knoll to $47.5 \mathrm{mg} \mathrm{kg}^{-1}$ in the depression and did not meet the stationarity requirement. Hence, no semivariograms for transect D were computed.

Several theoretical models of conditionally positive definite type could be fitted to the experimental semivariogram. The experimental and theoretical (fitted) semivariograms of DTPA-extractable soil $\mathrm{Zn}$ levels and tissue $\mathrm{Zn}$ concentration are given in Figures 4.5 , 4.6, 4.7 and 4.8. Using the minimum mean square deviation criterion, a linear model $\left({ }_{\gamma}(h)=C_{0}+b|H|\right)$ with discontinuity at the origin (nugget effect) best fits the experimental semivariograms of DTPAextractable soil $\mathrm{Zn}$ levels for all the transects. The semivariograms of tissue $\mathrm{Zn}$ concentration fits the linear model for transects $\mathrm{A}$ and $\mathrm{C}$ only. The fitted models (solid lines) show linear increase up to a lag of $25 \mathrm{~m}$ for transects A, B and C, respectiveiy (Figures 4.5, 4.6, 4.7a and 4.8), except for tissue $\mathrm{Zn}$ concentration of transect B (Fig. 4.7b) indicating that they were spatially dependent up to $25 \mathrm{~m}$. Therefore, samples separated by $25 \mathrm{~m}$ or more are generally not correlated to each other.

Although by definition $\gamma(h)=0$ when $h=0$, the lines in Eigure 4.5 through 4.10 do not pass through the origin. Instead, there appears to be finite value, the nugget variance $\left(c_{0}\right)$ to which $\gamma(h)$ approaches as $\mathrm{h}$ approaches zero. The nugget effect indicates microregionalization which may be due to both measurement error and to microvariabilities at scale which is less than the smallest distance 

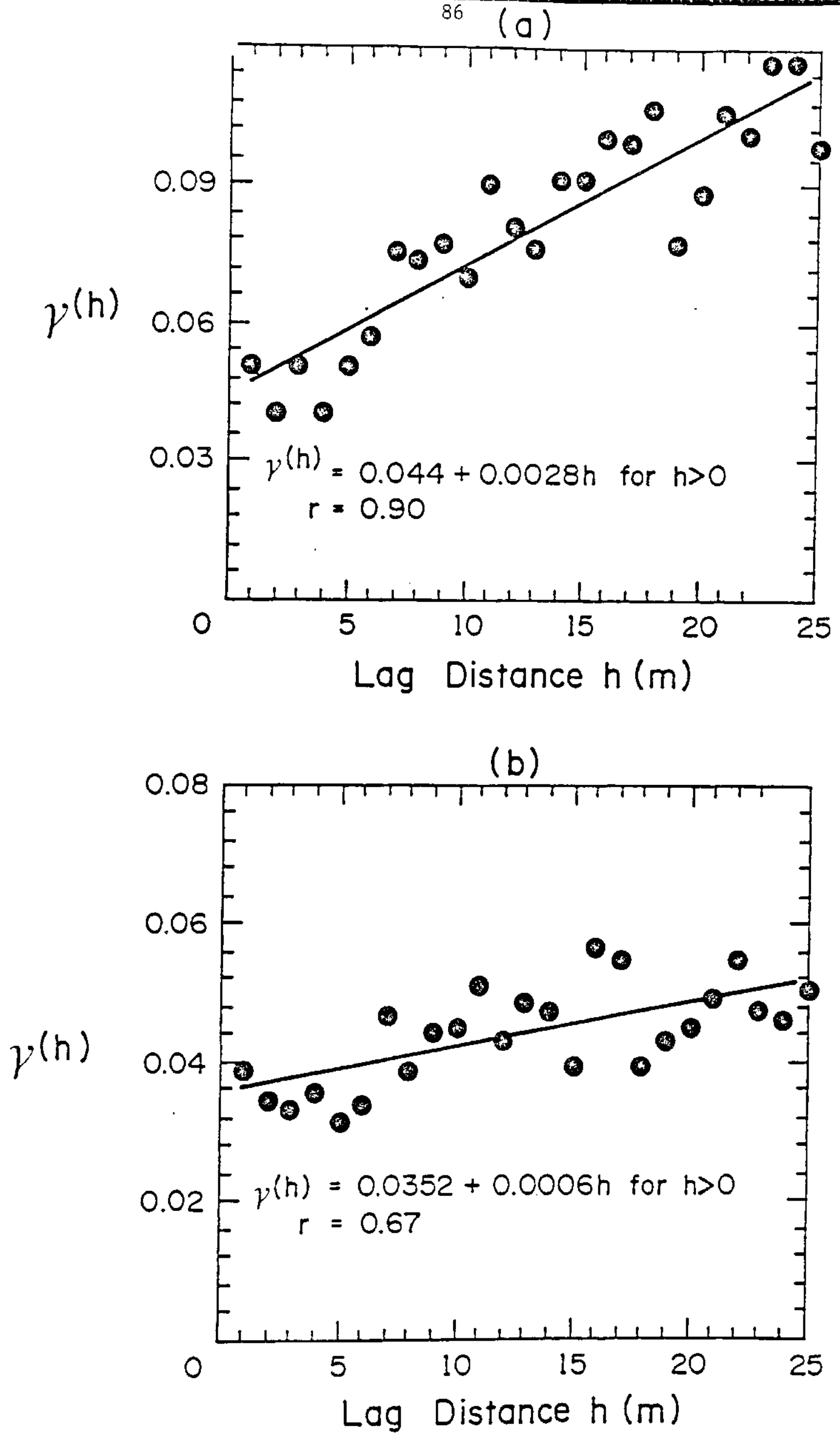

Figure 4.5 Experimental (black dots) and fitted models (solid lines) semi variograms for soil $\mathrm{Zn}$; (a) transect $A$, (b) transect $B$. 


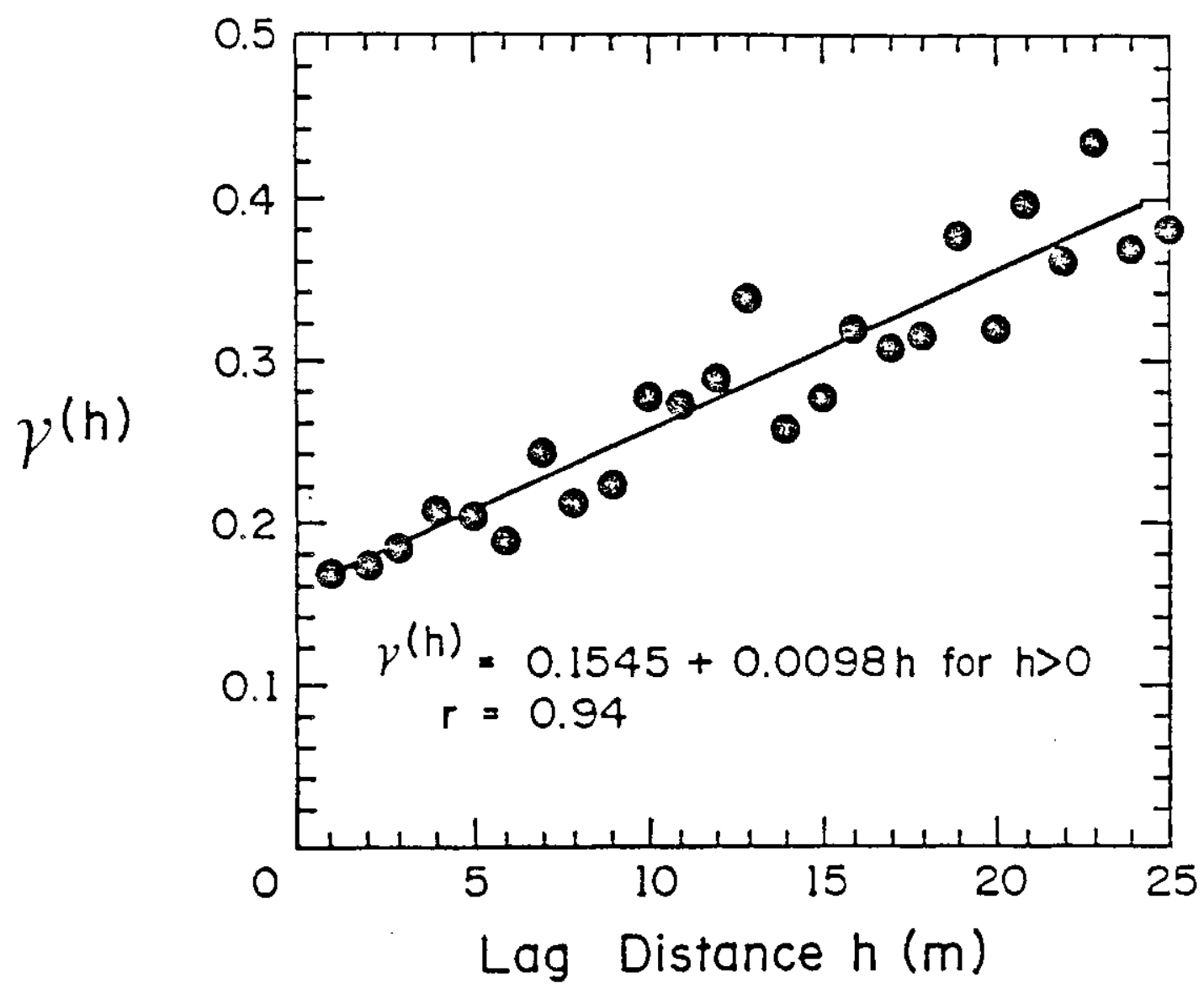

Figure 4.6 Experimental (black dots) and fitted model (solid line) semivariogram for soil $\mathrm{Zn}$ of transect $C$. 


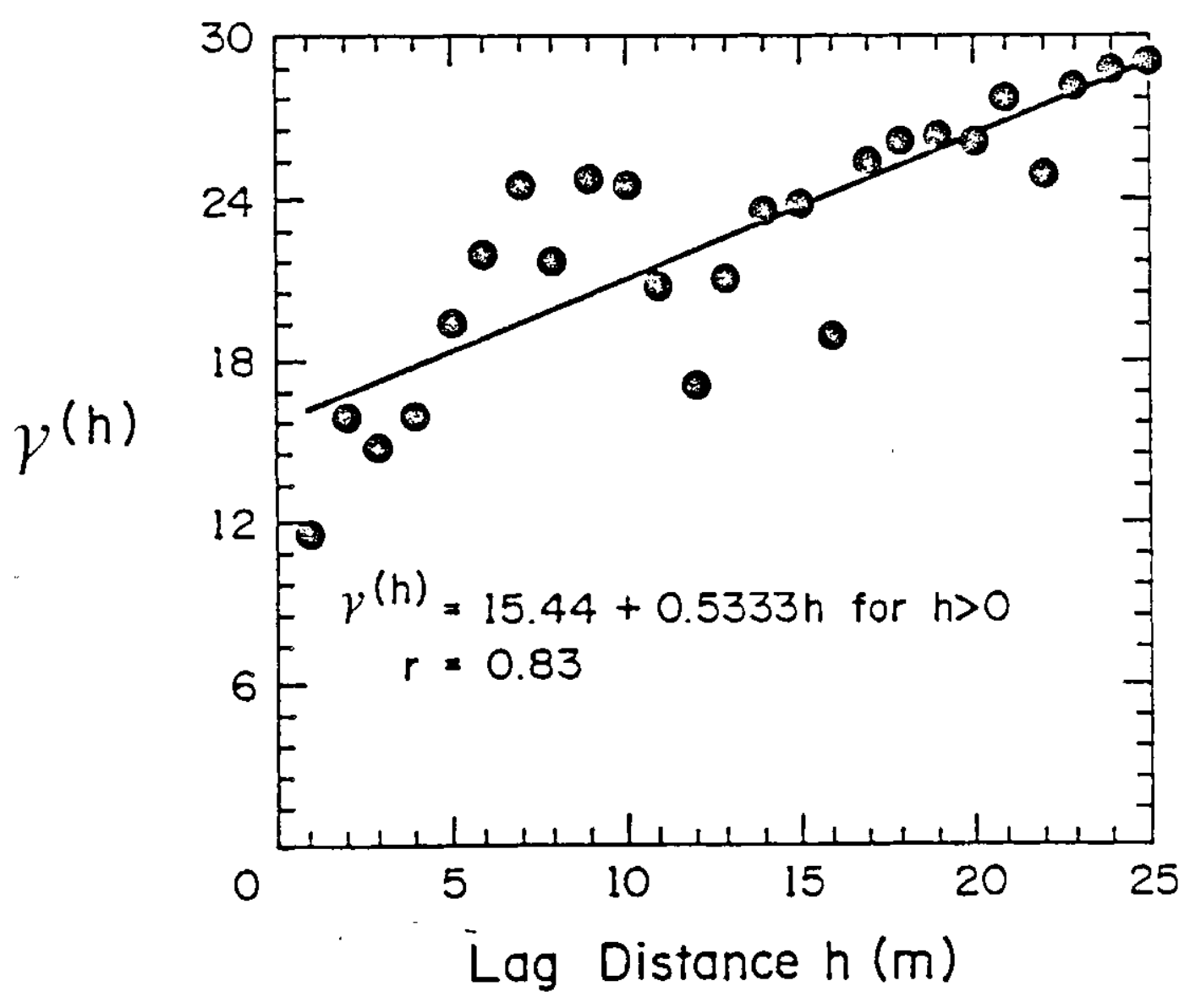

Figure 4.8 Experimental (black dots) and fitted model (solid line) semivariogram for plant $\mathrm{Zn}$ of transect $C$. 
between the sample points.

Statistical correlations between DTPA-extractable $\mathrm{zn}$ levels and selected soil and plant parameters were quantitatively estimated by means of linear correlation. Linear correlation coefficients are given in Table 4.1.8. The amount of $\mathrm{Zn}$ extracted by DTPA was positively correlated with organic $C$ and silt and negatively correlated with sand in all the transects. There was a significant negative correlation between DTPA-extractable $\mathrm{Zn}$ and soil pH or 1 ime content in two of the four transects studied.

Table 4.1.8 Correlation coefficients between DTPA-extractable $\mathrm{Zn}$ and selected soil and plant parameters.

\begin{tabular}{|c|c|c|c|c|c|c|c|}
\hline Transects & $\begin{array}{l}\text { Pl ant }-Z n \\
\text { mg kg }\end{array}$ & $\mathrm{pH}$ & Org. C & Inorg. C & $g \mathrm{~kg}^{-1}$ & Silt & Clay \\
\hline$A$ & $0.77^{* *}$ & $-0.35^{*}$ & $0.69^{* *}$ & -0.20 & $-0.33^{*}$ & $0.31^{*}$ & 0.12 \\
\hline B & $0.37^{* *}$ & -0.24 & $0.57^{* *}$ & $-0.52^{* *}$ & $-0.38^{* *}$ & $0.39^{* *}$ & 0.08 \\
\hline $\mathrm{C}$ & $0.58^{* *}$ & -0.26 & $0.87^{* *}$ & -0.20 & $-0.58^{* *}$ & $0.38^{* *}$ & 0.10 \\
\hline D & $0.73^{* *}$ & $-0.52^{* *}$ & $0.84^{* *}$ & -0.07 & $-0.34^{*}$ & $0.48^{* *}$ & 0.04 \\
\hline
\end{tabular}

* * Significant at the 0.05 and 0.01 probability levels, respectively.

Since a consistent and highly significant correlation between soil $\mathrm{Zn}$ and organic C (Table 4.1.8) was obtained in all the transects, an attempt was made to find out the spatial correlation between these two variables. This was done by making use of a cross-semivariogram (Eq. 4.2). An unbiased estimate for the cross-semivariogram between two soil properties $u$ and $v, \gamma(u v)$, is obtained by assuming constant expectation for both $u$ and $v$ (Journel and Huijbregts, 1978). 


$$
\gamma^{u v(h)}=-\frac{1}{2 n h} \sum_{i=1}^{n(h)}\left(\left[u\left(x_{i+h}\right)-u\left(x_{i}\right)\right]\left[v\left(x_{i+h}\right)-v\left(x_{i}\right)\right]\right) \quad[4.2]
$$

The experimental cross-semivariograms between soil $\mathrm{zn}$ and organic C for transects A, B and C are given in Figures 4.9 and 4.10 . Linear models with discontinuity at the origin best fit the experimental cross-semivariograms. Organic matter supplies complexing agents which promote the availability of certain elements (Hodgson, 1963). The fact that extractable $\mathrm{Zn}$ was correlated with organic $\mathrm{C}$ indicates that organic $C$ has a major effect on DTPA-extractable $\mathrm{Zn}$. The cross-semi variograms presented in Figures 4.9 and 4.10 demonstrate that the two parameters have the same spatial structure. This also suggests that the spatial structure fo soil $\mathrm{zn}$ can be inferred from the spatial structure of organic $C$ for a particular soil mapping unit or soil site. This conclusion agrees with the earlier findings of Stewart and Tahir (1971), who found a highly significant positive correlation between DTPA-extractable soil $\mathrm{Zn}$ levels and organic $\mathrm{C}$ contents in 24 soils of Saskatchewan.

A significant correlation was obtained between DTPA-extractable soil $\mathrm{Zn}$ and $\mathrm{pl}$ ant $\mathrm{Zn}$ (Table 4.1.8). This indicates that soil variability was reflected in plant $\mathrm{zn}$ content. 

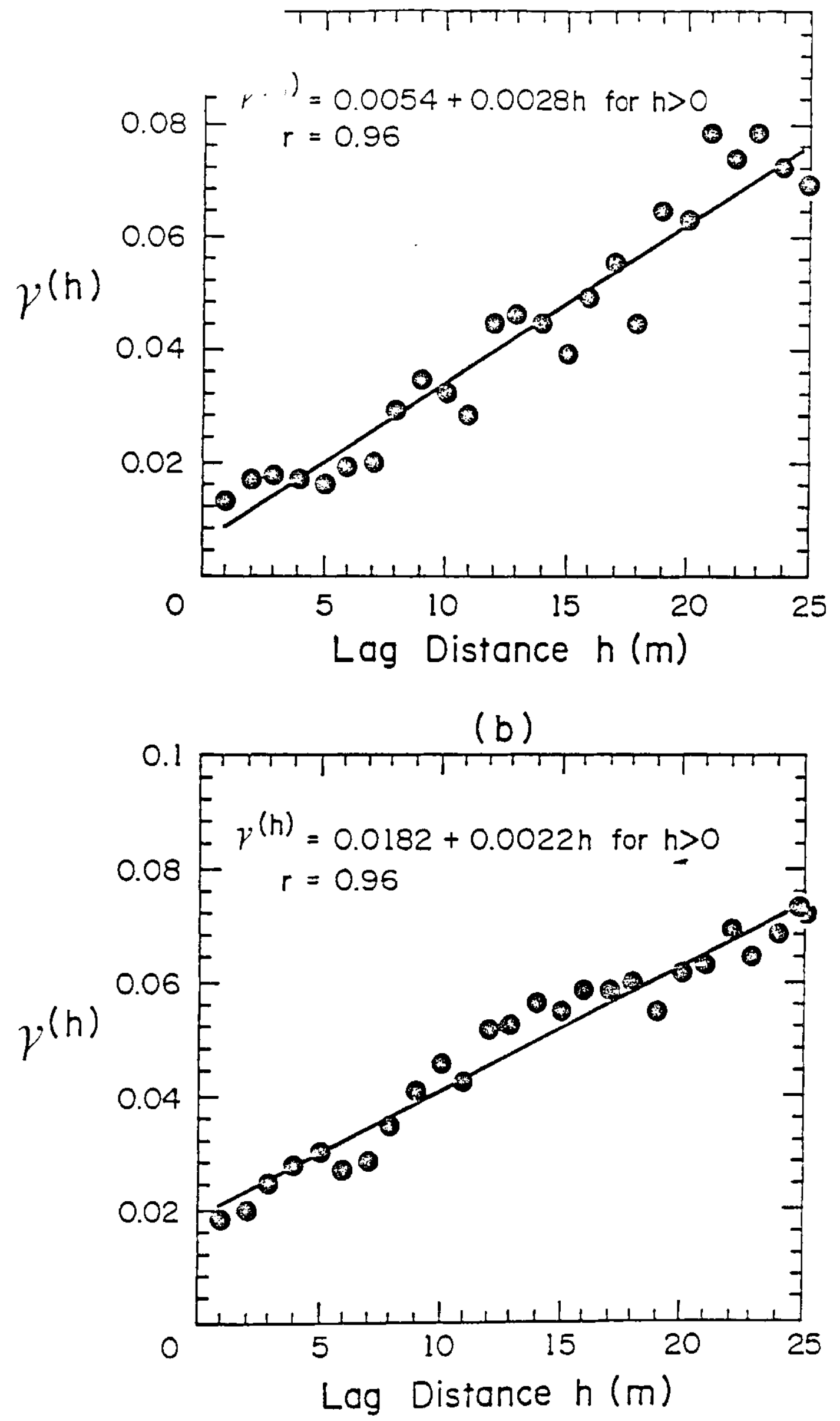

Figure 4.9 Experimental (black dots) and fitted models (solid lines) cross-semi variograms between soil $\mathrm{Zn}$ and organic carbon; (a) transect $A$, (b) transect $B$. 


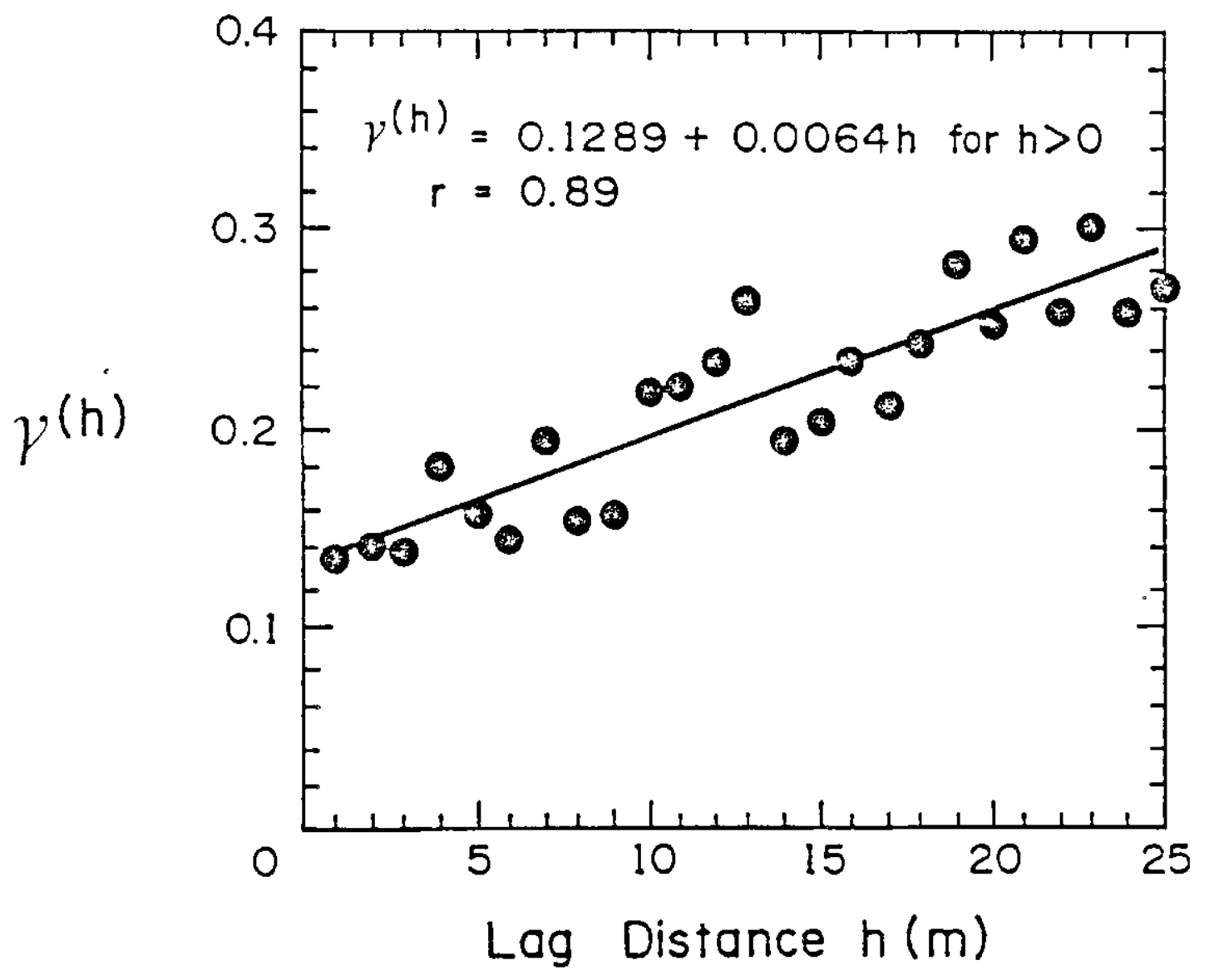

Figure 4.10 Experimental (black dots) and fitted model (solid line) cross-semi variogram between soil $\mathrm{Zn}$ and organi carbon for transect $C$. 
4.2 Importance of $\mathrm{Zn}$ to Crop Nutrition and Production of Conmon Crops 4.2.1 Zinc status of Saskatchewan soils

\subsubsection{Exploratory surveys}

Approximately $12 \%$ of the soil samples in the population examined had $\mathrm{Zn}$ levels below the critical value of $0.5 \mathrm{mg} \mathrm{kg}^{-1}$ soil (Class 1) adopted by the SSTL, while approximately $37 \%$ belonged to Class 2 (Table 4.2.i). DTPA-extractabie $\mathrm{zn}$ i eveis ranged between 0.2 and $10.0 \mathrm{mg} \mathrm{kg}^{-1}$ with an average value of $1.7 \mathrm{mg} \mathrm{kg}^{-1}(S D \pm 1.6)$. In contrast to $\mathrm{Cu}$, where most soil samples containing marginal levels belonged to identifiable soil associations (Kruger et al., 1985), soils in $\mathrm{Zn}$ Class 1 represented localized conditions rather than generalized areas and had the following characteristios: They were either (i) loams with lime present and/or $\mathrm{pH}$ between 7.9 and 8.2 , or (ii) clay loams, clays and heavy clays (within the Fox Valley, Sceptre, Echo, Ardill, Amulet, Trossachs and Regina soil associations (Mitchell et al., 1944; Ellis et al., 1965b)) with 1 ime present (>70\% of the cases) and/or with $\mathrm{pH}$ in the range of 7.8 to 8.3 (>85\% of the cases), or (iii) sands with pH 7.0 to 8.0 .

Table 4.2.1 Distribution of DTPA-extractable Zn levels.

\begin{tabular}{lcc}
\hline Class & $\begin{array}{c}\text { DTPA-extractable } \\
(\mathrm{mg} \mathrm{kg})\end{array}$ & $\begin{array}{c}\text { Distribution } \\
(\%)\end{array}$ \\
\hline 1 & $<0.50$ & 12 \\
2 & $0.50-1.0$ & 37 \\
3 & $>1.0$ & 51 \\
\hline
\end{tabular}


There are a number of reports that suggest that $\mathrm{Zn}$ availability is highly related to $\mathrm{pH}$ and calcium carbonate content of soils. Both Zn solubility (Lindsay and Norvell, 1969) and $Z n$ adsorption by soil colloids (Shuman, 1980) are strongly pH dependent. Further, since $\mathrm{Zn}$ is strongly adsorbed on calcium carbonate (Udo et al., 1970), this may explain why low DTPA-extractable soil $\mathrm{Zn}$ levels were associated with high lime content soils. Furthermore, it has been shown that liming of acid soils decreased the concentration of soluble $\mathrm{Zn}$ (Maclean et al., 1972) and that DTPA-extractable $\mathrm{Zn}$ levels were inversely related to cal cium carbonate content of soirls (Mashhady, 1983).

\subsubsection{Field experiments with Zn Pertilizers}

A number of field trials were conducted during 1982, 1983 and 1984 on several soils belonging to the three classes in Table 4.2 .1$. Detailed results of all 1982 and 1983 experiments grouped on the basis of soil Zn levels are presented in Tables $4.2 .2,4.2 .3$ and 4.2 .4 and are summarized on a per crop and soil Zone basis in Table 4.2.5. The results indicate that crops grown on mineral soils in saskatchewan are not likely to respond to Zn fertilization. Eleven experiments (27 treatments) with spring wheat (hard red or soft red or white), six experiments (12 treatments) with barley and six experiments ( 15 treatments) with lentils, peas, alfalfa, corn and flax produced only one significant yield increase (Table 4.2.5), i.e. <2\% of the treatments applied. Similar results have been found in the neighboring province of Manitoba, where seven experiments with black beans and 16 with corn have only produced one significant yield response to $\mathrm{zn}$ for each crop, while yields of cereals, flax and alfalfa in a number of 


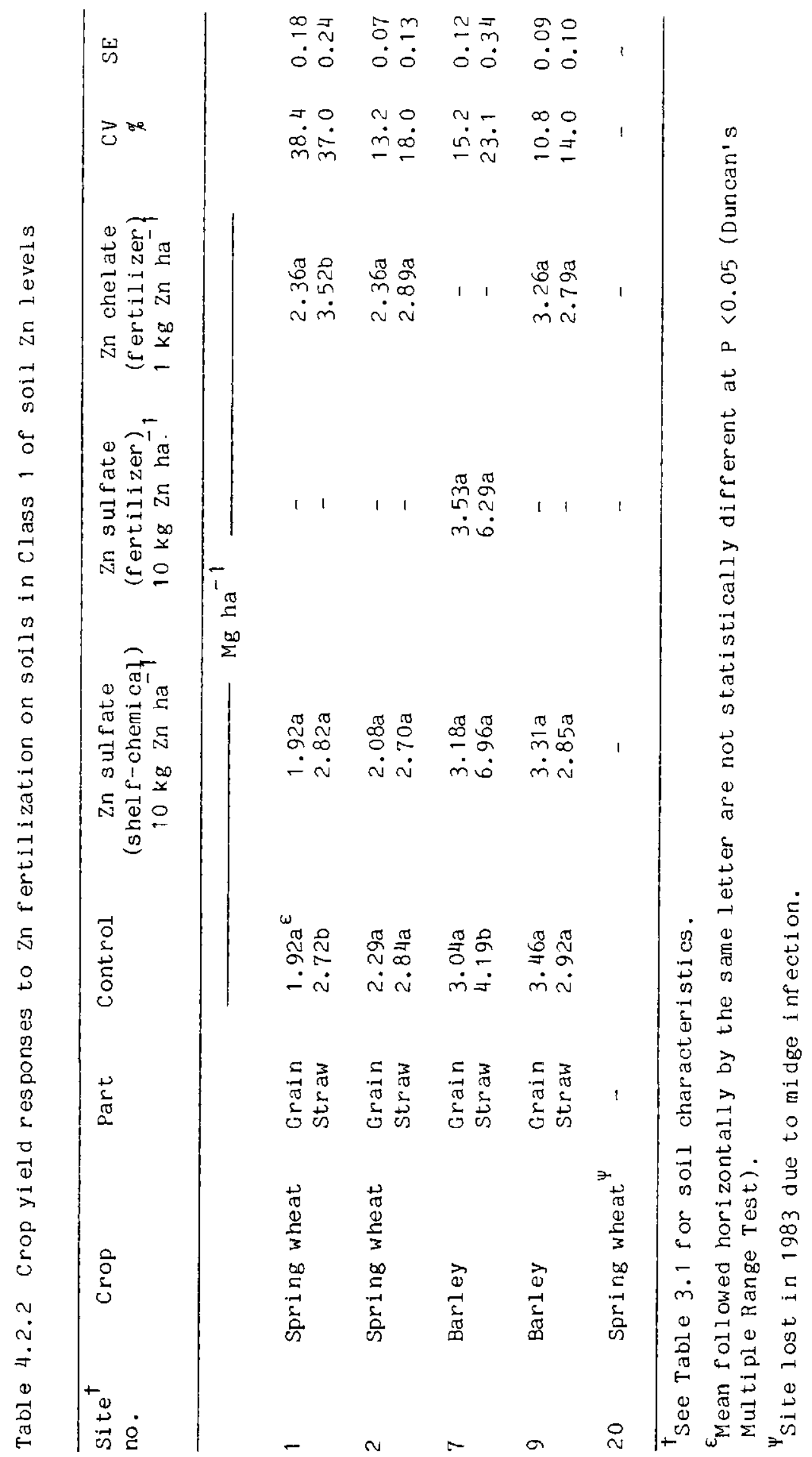




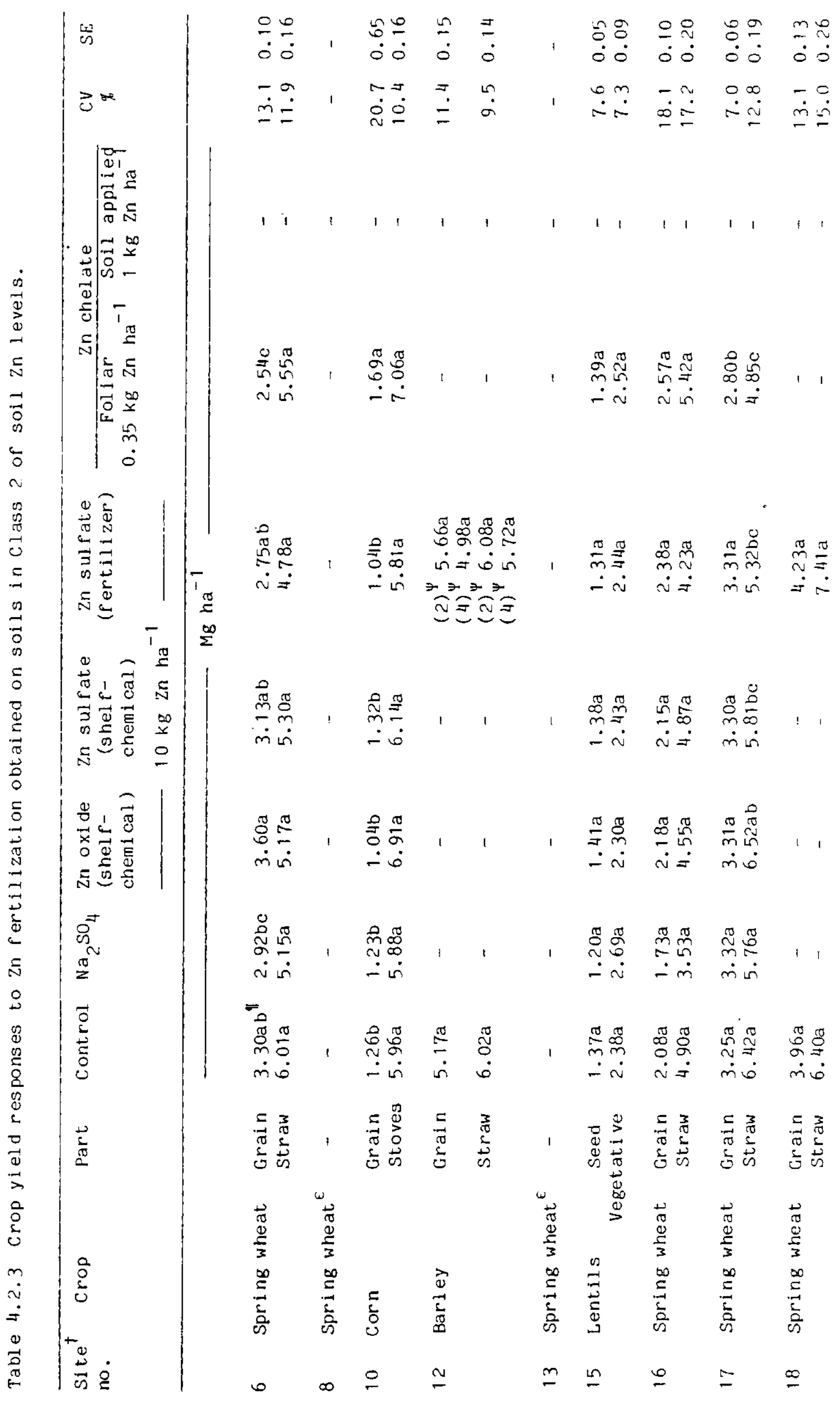




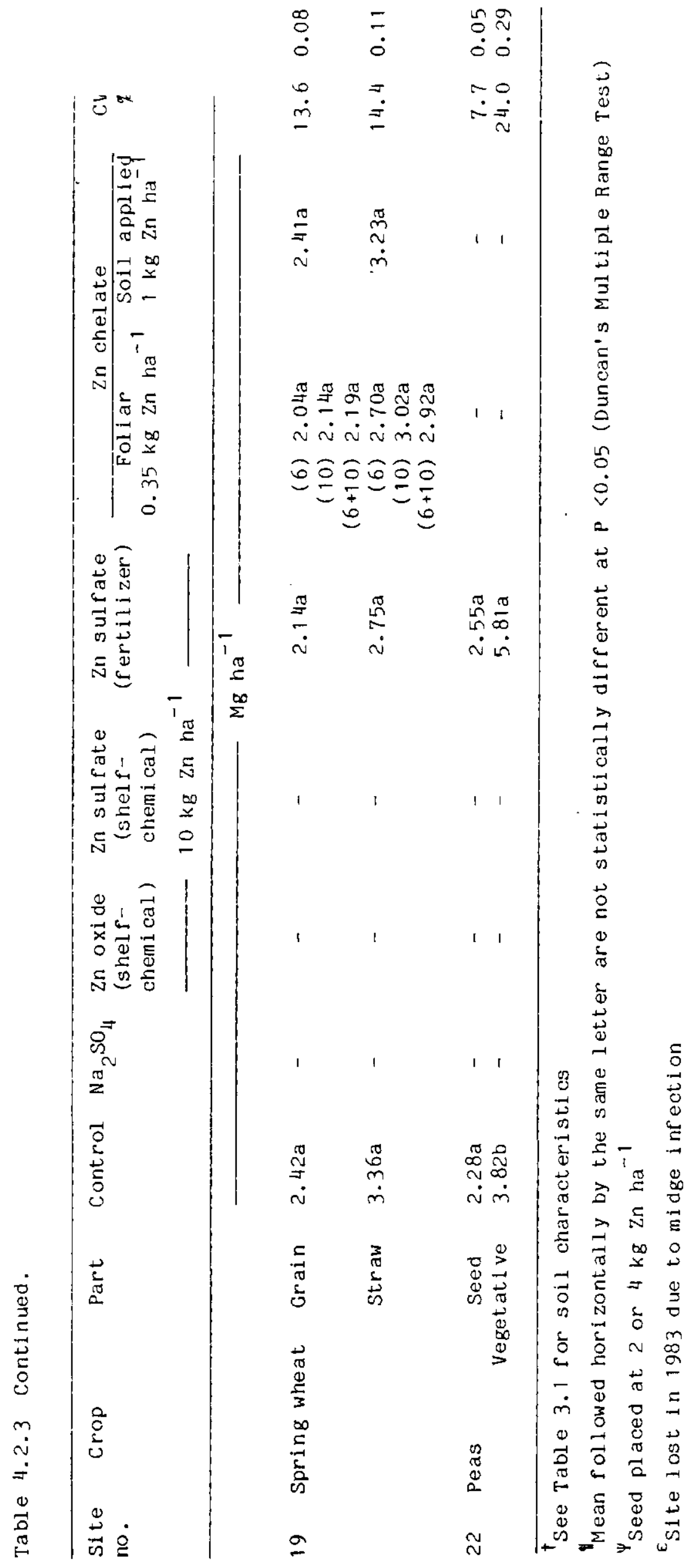




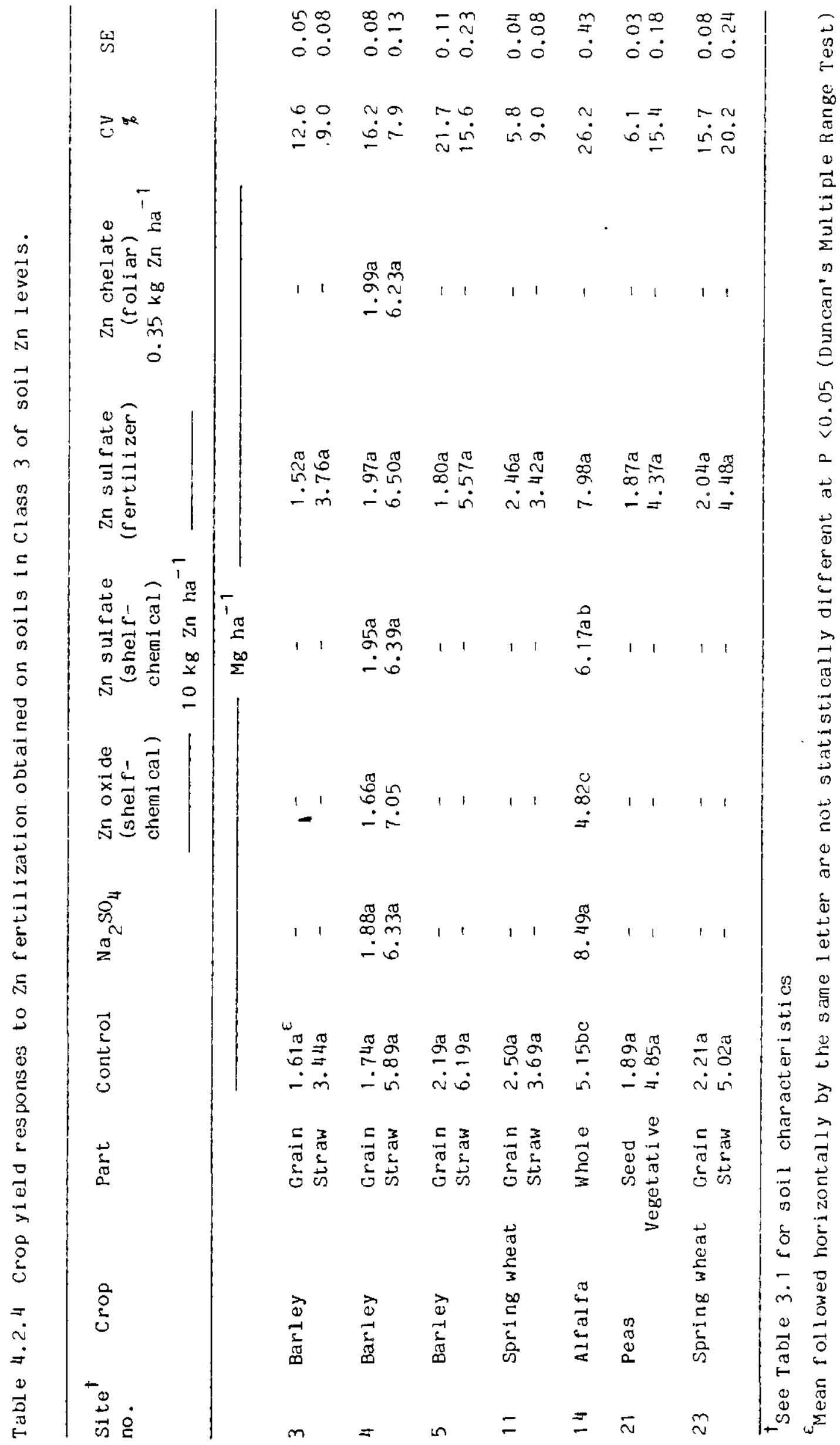




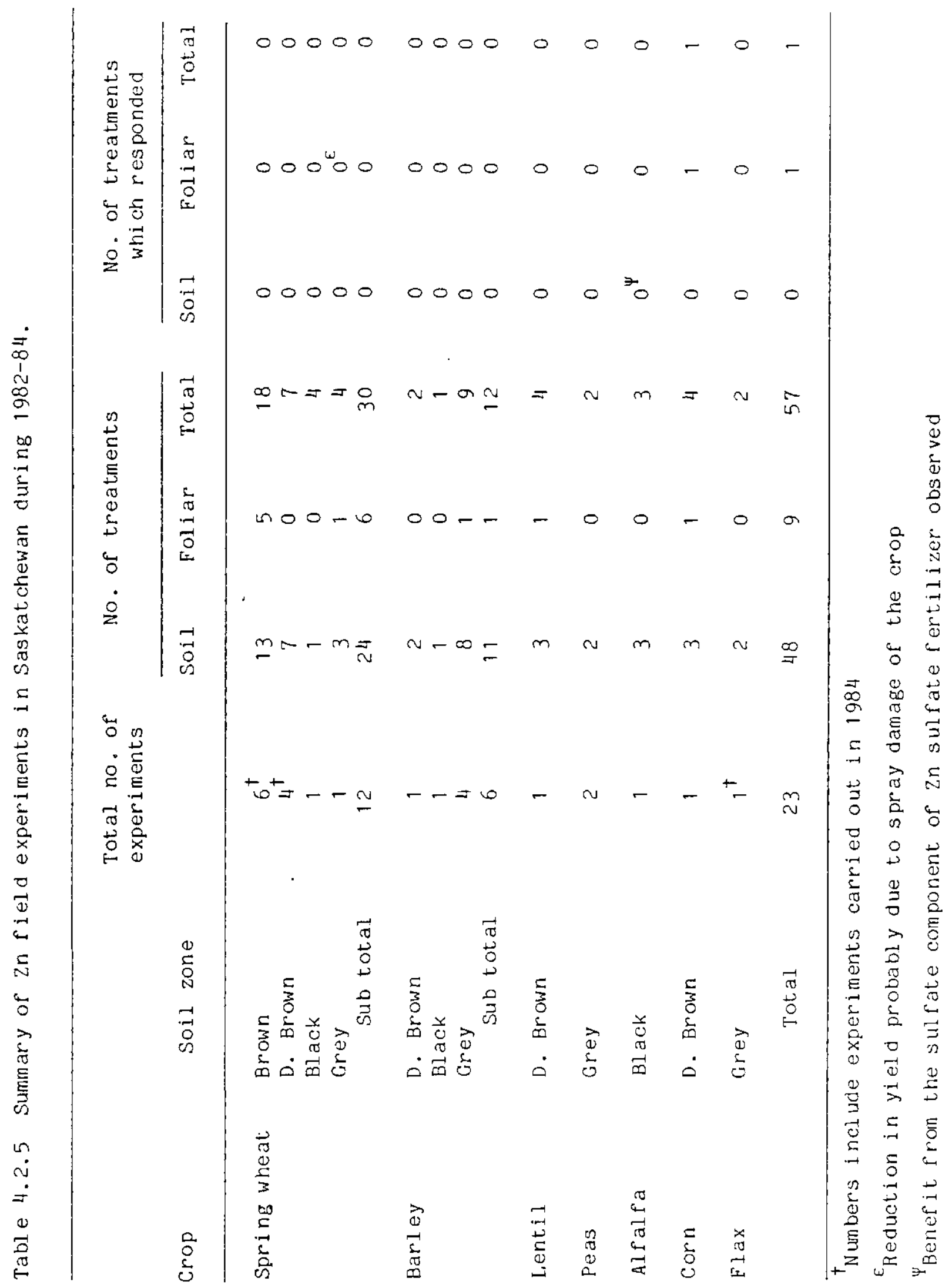


experiments were not increased as a result of micronutrient fertilizer application (Loewen-Rudgers et al., 1983). No responses to Zn fertilization have also been obtained in field studies with corn and sunflower in northern West Virginia and North Dakota soils in spite of soil test levels of $\mathrm{Zn}$ below the oritical limit (Stout and Bennett, 1983; Hilton and Zubriski, 1985).

Zinc fertilization of field crops did not al ways increase the Zn concentations in plant tissue during the growing season or those of grain and straw (Tables 4.2.6, 4.1.7 and 4.2.8). Only in $25 \%$ of the cases did Zn fertilization cause a significant increase in Zn levels in plant tissue of various crops (Table 4.2.9). These results would indicate that $\mathrm{Zn}$ from soil sources was sufficient to meet the $\mathrm{Zn}$ uptake requirements by various crops.

Soil applied $\mathrm{Zn}$-sulfate had a residual effect as $f$ ar as DTPA-extractable $\mathrm{Zn}$ soil levels are concerned (Table 4.2.11). Soil application of $\mathrm{Zn}$-chelate resulted in increased DTPA-extractable $\mathrm{zn}$ levels in two of the four experiments in spite of the low application rates (Table 4.2.11). No yield benefits were obtained, however, from residual $Z n$ levels in either case (Table 4.2.10). This would indicate that $\mathrm{Zn}$ was not limiting grain yield. Relatively large soil applications of $\mathrm{Zn}$ have been found to exert an appreciable influence $f$ or a relatively long period of time. Boawn et al. (1960) reported that high proportion of $\mathrm{Zn}$ from 9 and $18 \mathrm{~kg} \mathrm{Zn}$ ha $^{-1}$ application rates were still present in the acid extract of a Ritzville fine sand loam after 5 years. Application of 11 and $22 \mathrm{~kg} \mathrm{Zn} \mathrm{ha}^{-1}$ as $\mathrm{Zn}$ sulfate reflected residual $\mathrm{Zn}$ availability by soil and plant analysis after 2 years (Ellis et al., 1965a). Ohki et al. (1976) observed increased corn 


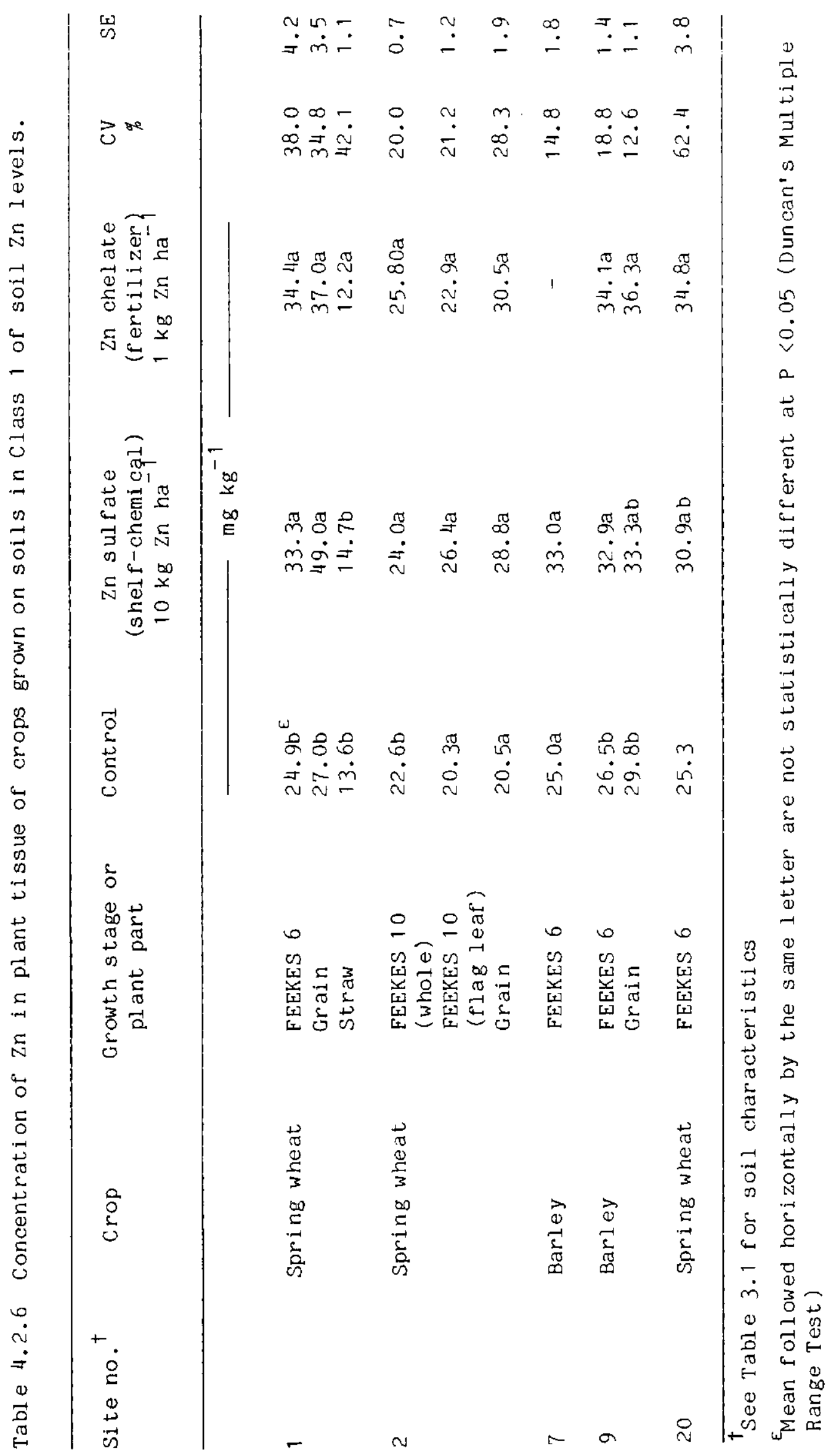




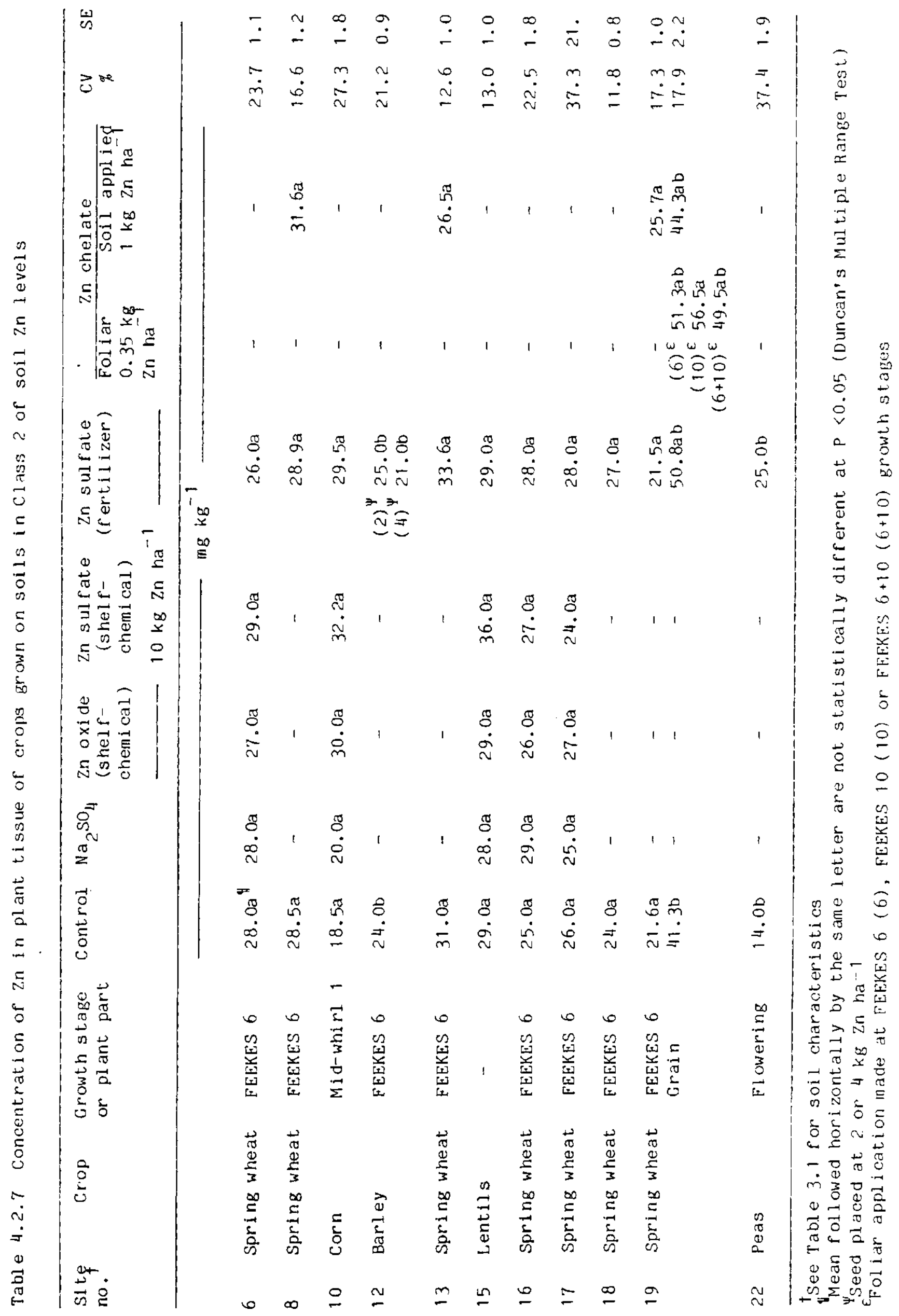




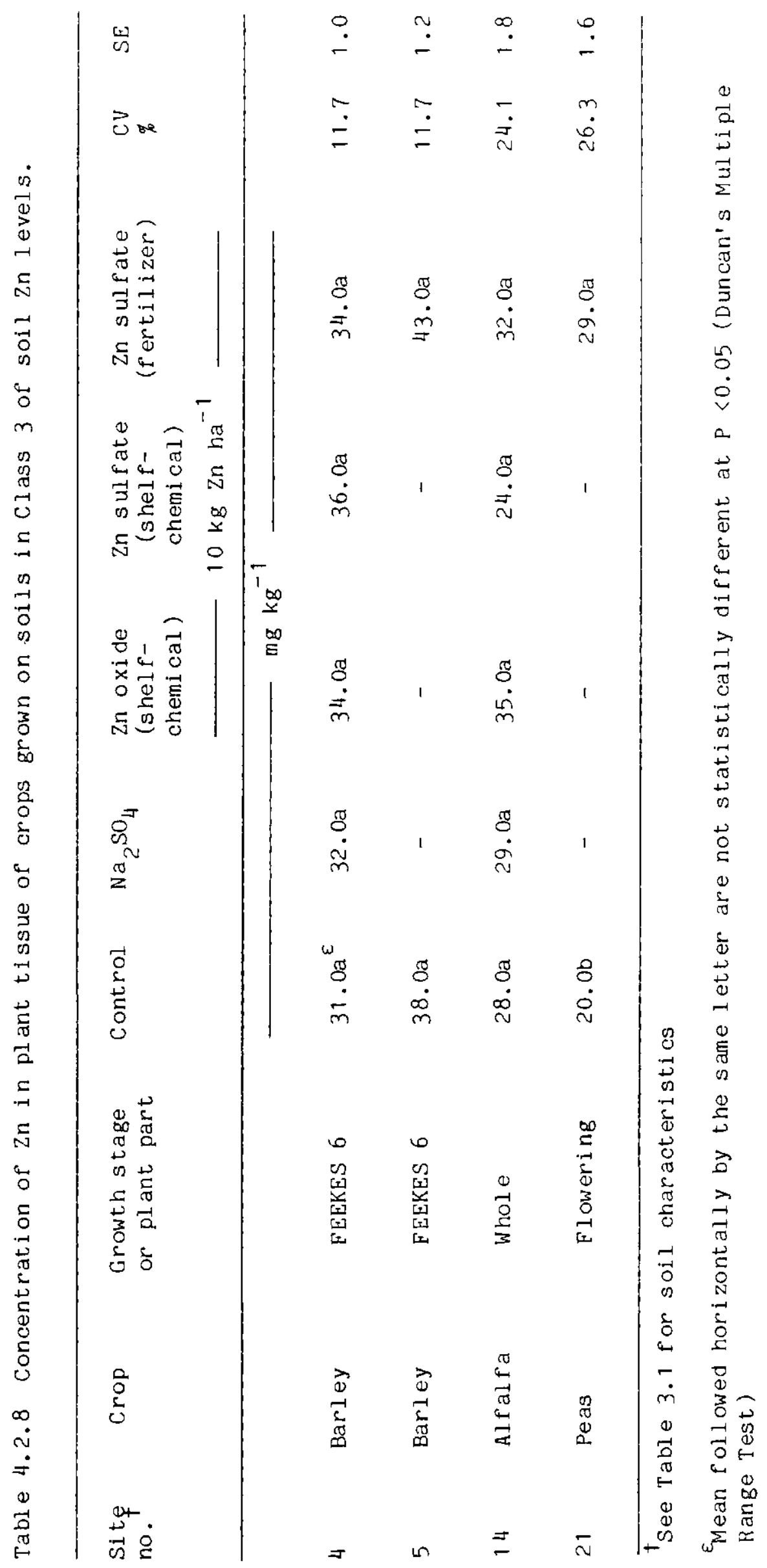




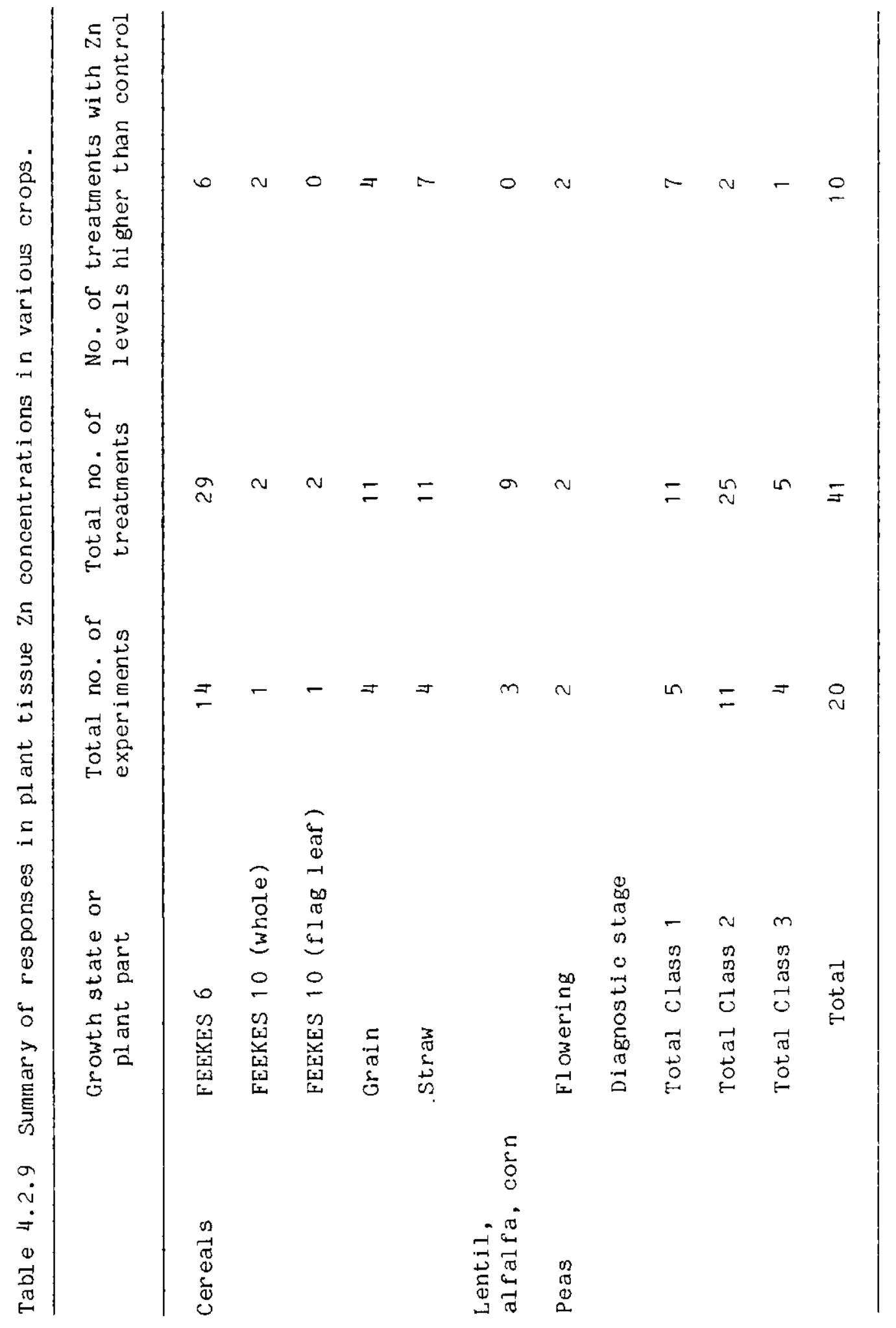




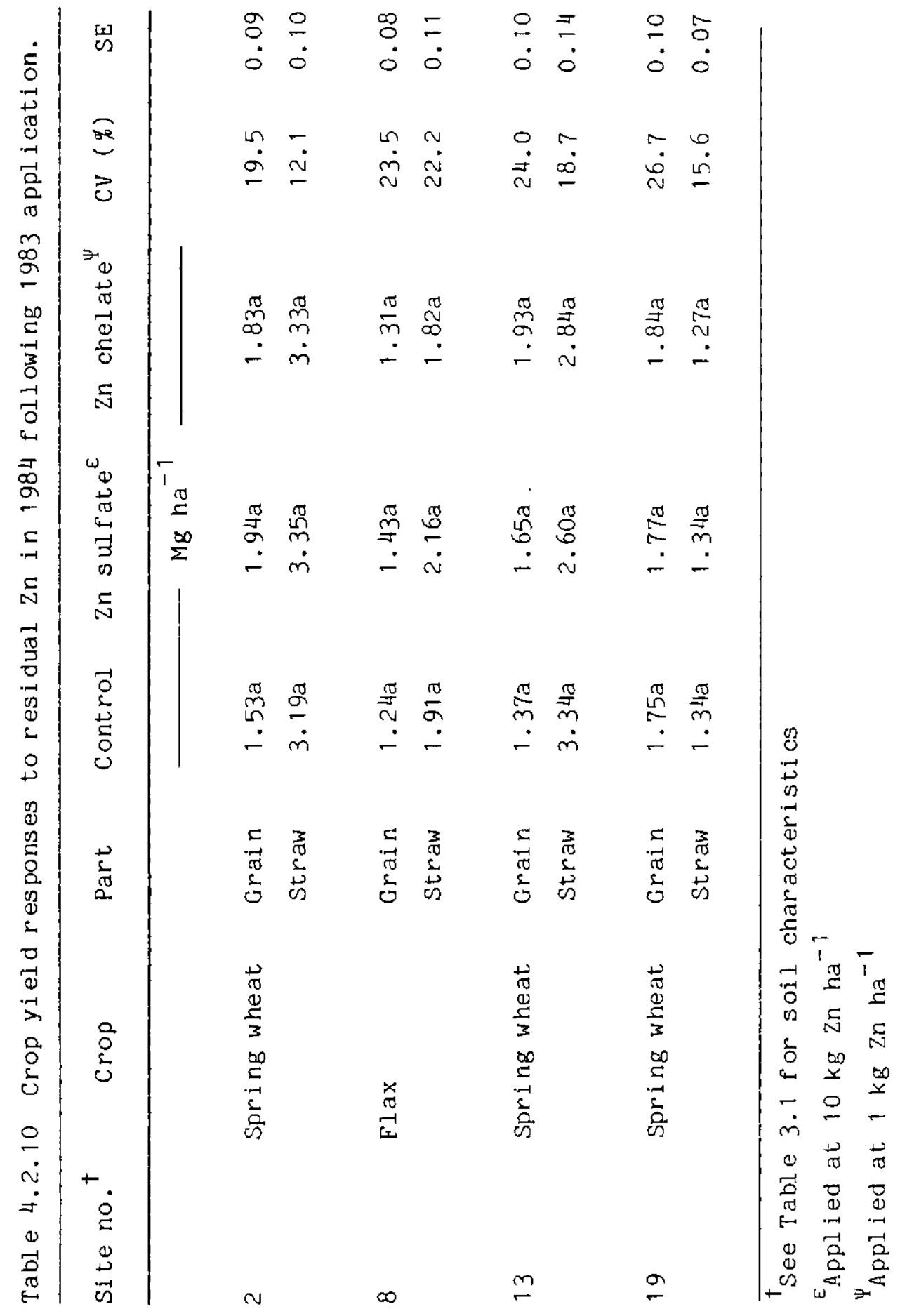


Table 4.2.11 DTPA-extractable $2 n$ levels in soil samples $(0-15 \mathrm{~cm})$.

\begin{tabular}{lcccc}
\hline $\begin{array}{l}\text { Site } \\
\text { no. }\end{array}$ & $\begin{array}{c}\text { Control (whole site) } \\
\text { Control }\end{array}$ & Zn sulfatet & Zn chelate \\
\hline & & $\mathrm{mg} \mathrm{kg^{-1 }}$ \\
2 & 0.35 & 0.40 & 1.54 & 0.77 \\
8 & 0.60 & 1.10 & 1.60 & 1.68 \\
13 & 0.55 & 0.55 & 2.28 & 0.64 \\
19 & 0.75 & 0.60 & 1.50 & 0.65 \\
\hline
\end{tabular}

†pplied at $10 \mathrm{~kg} \mathrm{Zn} \mathrm{ha}-1$

$\Psi_{\text {Applied at } 1 \mathrm{~kg} \mathrm{Zn} \mathrm{ha}}{ }^{-1}$

tissue $\mathrm{Zn}$ concentration and soil $\mathrm{Zn}$ levels at higher $\mathrm{Zn}$ rates indicating that residual effects were evident through the fourth growing year after $\mathrm{Zn}$ application. However, plant dry weight and grain yield were not affected significantly by residual Zn levels. 


\subsubsection{P X Zn interaction in wheat \\ 4.2.2.1 Yields}

Phosphate applied in 1979 resulted in increased resin extractable $\mathrm{P}$ levels six years after application $\left(18.6,28.2\right.$ and $58 \mathrm{~kg} \mathrm{ha}^{-1}$ for the check and applied $P$ rates of 80 and $160 \mathrm{~kg} \mathrm{P} \mathrm{ha}^{-1}$, respectively). Grain and straw yield of wheat grown on $P$ treatments only was significantly higher than the control (Tables 4.2 .12 and 4.2.13). However, there was no significant difference in grain yield between 80 and $160 \mathrm{~kg} \mathrm{P} \mathrm{ha}{ }^{-1}$ treatments (Tables 4.2 .12 and 4.2.13). Similar long-term responses to residual phosphate levels have been observed in northern Great Plains soils and crops (Read et al., 1973; 1977; Halvorson and Black, $1985 a, b)$.

Mean grain yield responses to soil applied zn were significant with both types of $\mathrm{Zn}$ fertilizers (Tables 4.2.12 and 4.2.13). Foliar application of 2 n-chelate at either FEEKES 6 or EEEKES 10 growth stage was equally effective in increasing grain yield (Table 4.2.13). The $\mathrm{P} X \mathrm{Zn}$ interaction was significant for each source of applied $\mathrm{Zn}$ as demonstrated in grain yield. In all three experiments, yield responses to $P$ were significantly $I$ arger when $Z n$ was applied. At 80 $\mathrm{kg} \mathrm{P} \mathrm{ha}^{-1}$, addition of $\mathrm{Zn}$-sulfate increased grain yield from 1.72 to $2.42 \mathrm{Mg} \mathrm{na}{ }^{-1}$ (Tables 4.2 .12 and 4.2.13). Addition of $\mathrm{zn}$-chelate at the same $P$ treatment resulted in significant response from 1.72 to $2.12 \mathrm{Mg} \mathrm{ha}{ }^{-1}$ (Tables 4.2 .12 and 4.2.13). On the check $\mathrm{P}$ plots however, there was no response to any source of applied $\mathrm{n}$ (Tables 4.2.12 and 4.2.13). A 42\% increase in yield above the residual effect of $80 \mathrm{~kg} \mathrm{Pha}{ }^{-1}$, or $0.72 \mathrm{Mg}$ of $\mathrm{grain} \mathrm{ha}^{-1}$ could be attributed to foliar applied $2 n$ in this treatment. The corresponding additional 


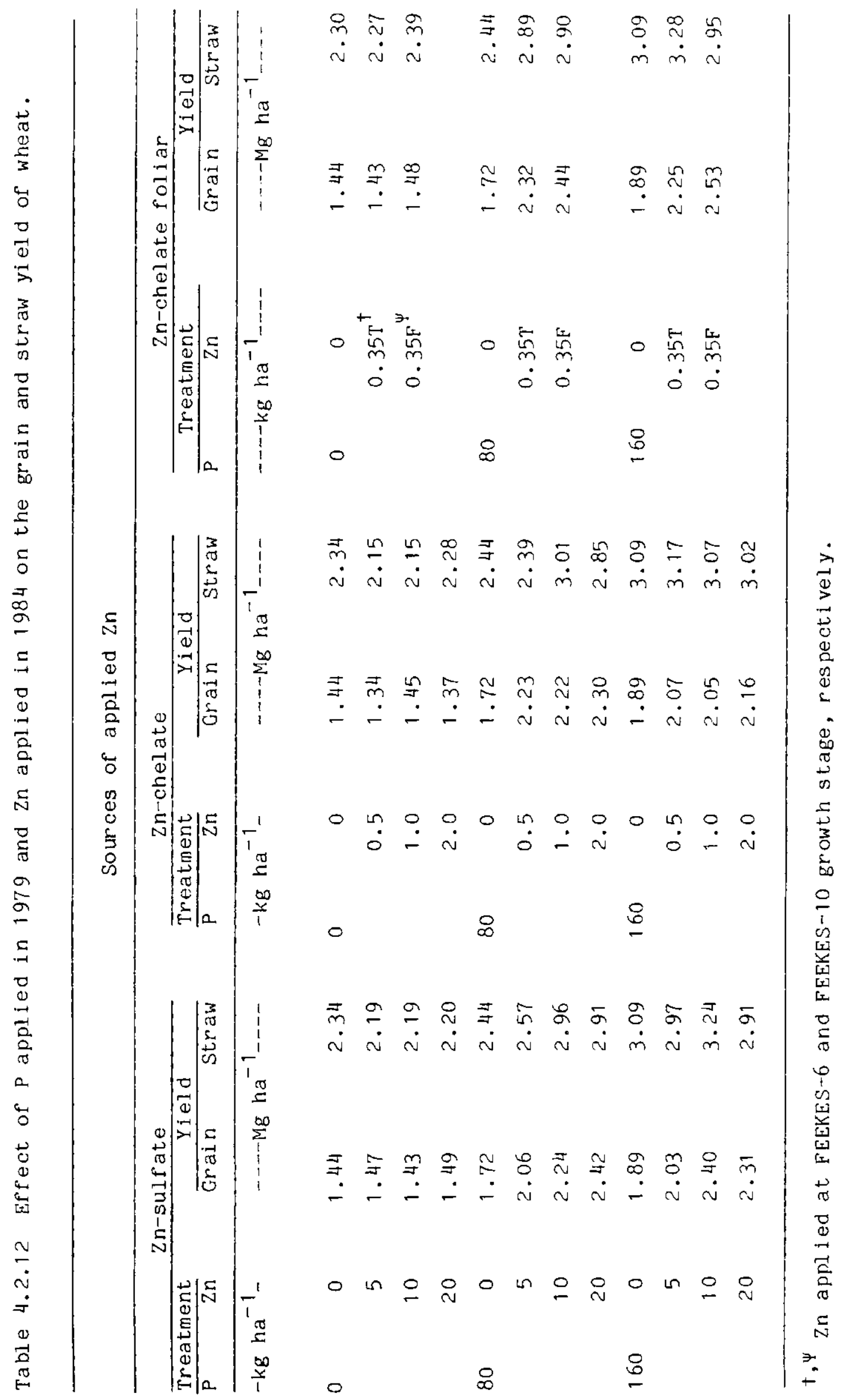




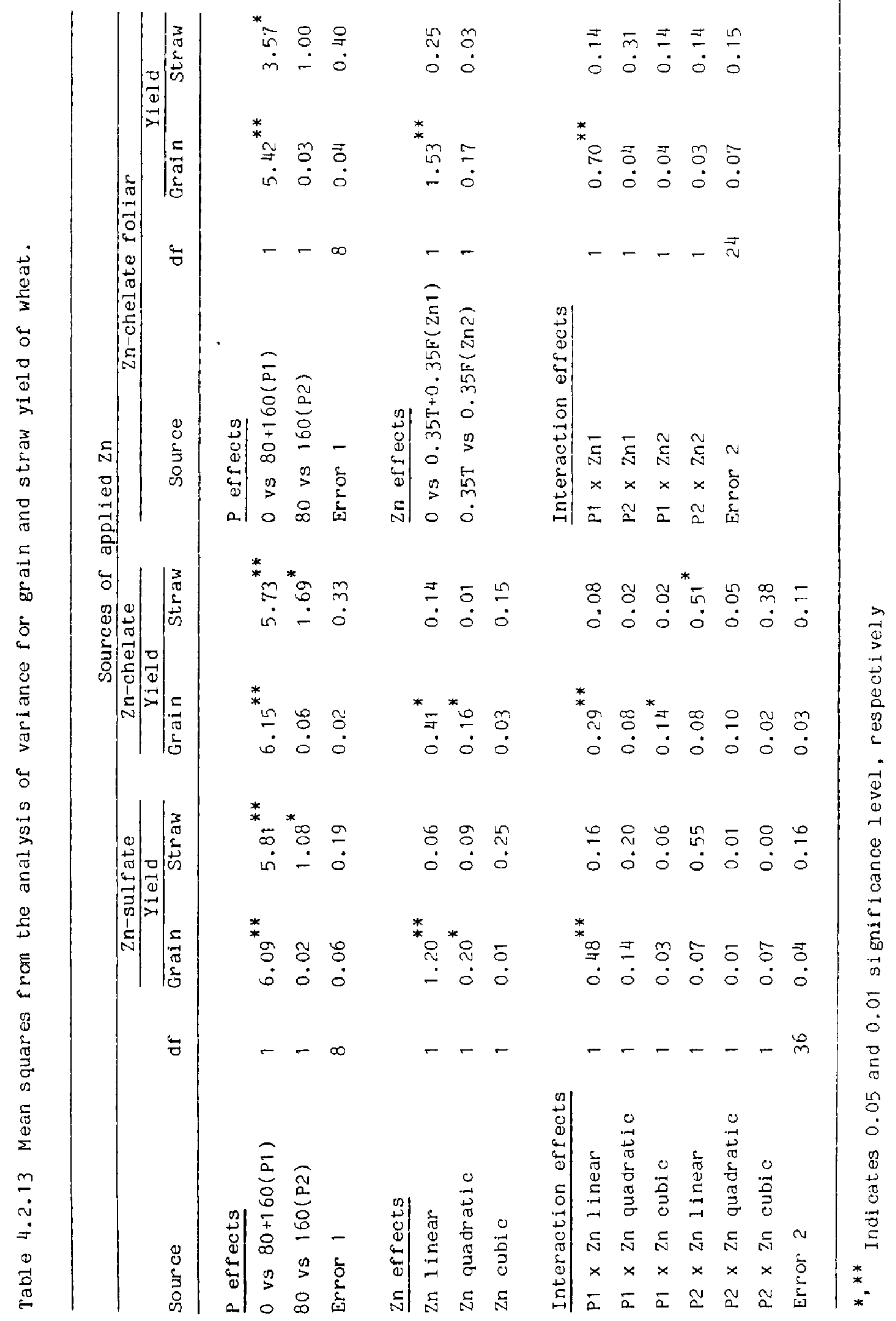


benefits with the application of $\mathrm{Zn}$-sulfate and $2 n-c h e l$ ate were 30 and $31 \%$ yield increases or 0.52 and $0.53 \mathrm{Mg}$ of grain ha ${ }^{-1}$, respectively (Table 4.2 .12$)$

\subsubsection{Nutrient distribution in the fol iage}

The concentrations of $P$ in wheat plant tissue at FEEKES 6 and FEEKES 10 growth stages was not affected by either $\mathrm{Zn}$-source or $\mathrm{Zn}$ application rate (Tables 4.2 .14 and 4.2.15). However, the p concentration was significantly higher in the treatments that received 80 and $160 \mathrm{~kg} \mathrm{Pha}^{-1} 6$ years before than in the control.

The $\mathrm{Zn}$ concentration in wheat plant tissue responded to $\mathrm{Zn}$ rate for both soil applied sources at FEEKES 6 and at FEEKES 10 (Table 4.2.15). Foliar application of $\mathrm{Zn}$-chelate at FEEKES 6 stage caused a significant increase in the $\mathrm{Zn}$ concentration at FEEKES 10 (Table 4.2.16). The residual amounts of $P$ six years after application resulted in significant decrease in the $\mathrm{Zn}$ concentration of plant tissue at both growth stages. In addition, the $\mathrm{zn}$ concentration at FEEKES 10 of plants grown on treatments where 1 arge amounts of $P$ had been applied six years before (Tables 4.2 .14 and 4.2 .16 ), approached that considered critical (20 $\mathrm{mg} \mathrm{zn} \mathrm{kg}^{-1}$ ) for normal plant growth (Melsted et al., 1969; Radjagukguk et al., 1980).

\subsubsection{Nutrient uptake and distribution at maturity}

The residual soil $P$ levels in the 80 or $160 \mathrm{~kg} \mathrm{P} \mathrm{ha}$ treatments resulted in a significant decrease in the $\mathrm{zn}$ concentration and uptake in straw, but in grain, only the $\mathrm{Zn}$ concentration was decreased significantly (Tables 4.2 .17 to 4.2.22). However, there 


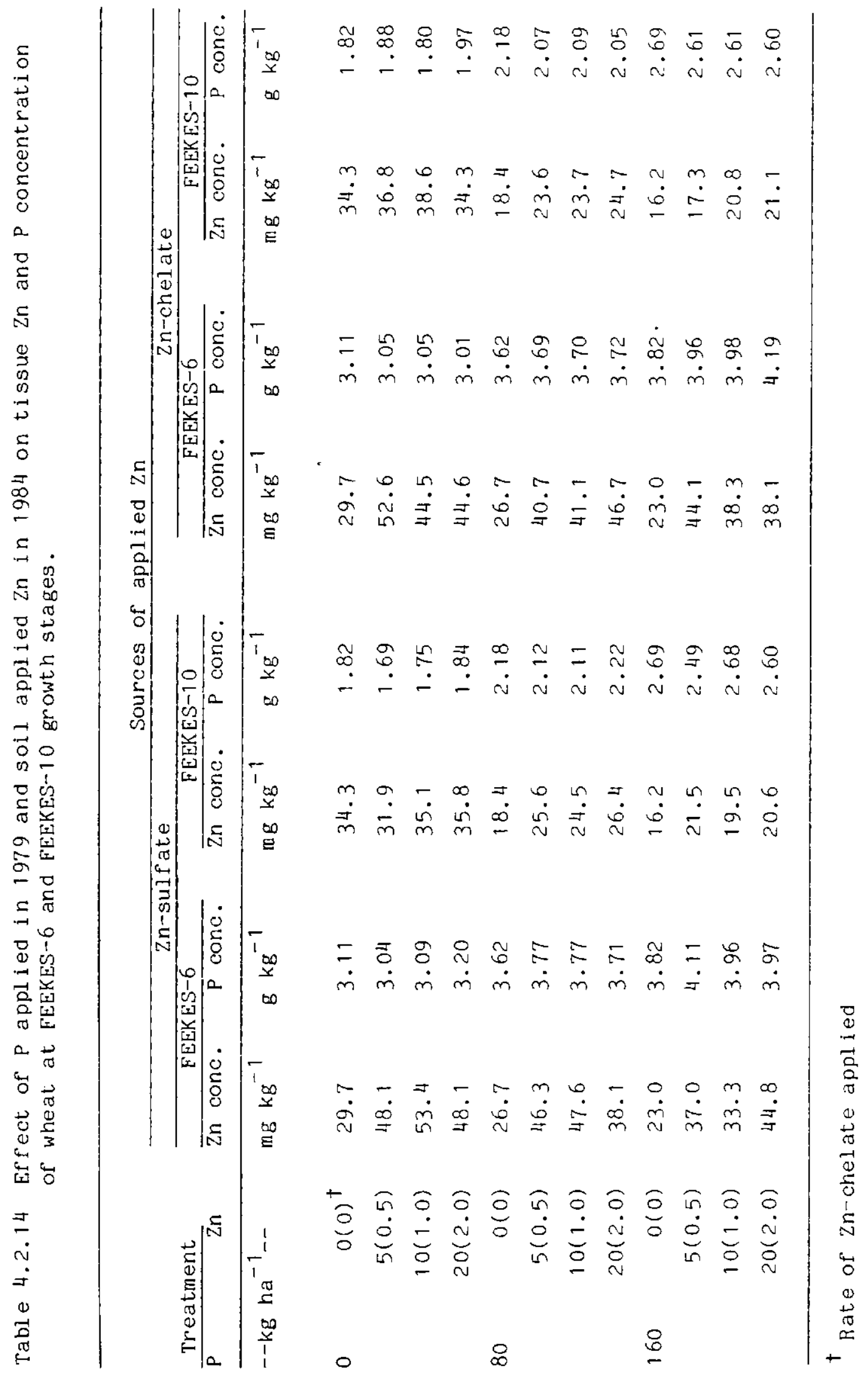




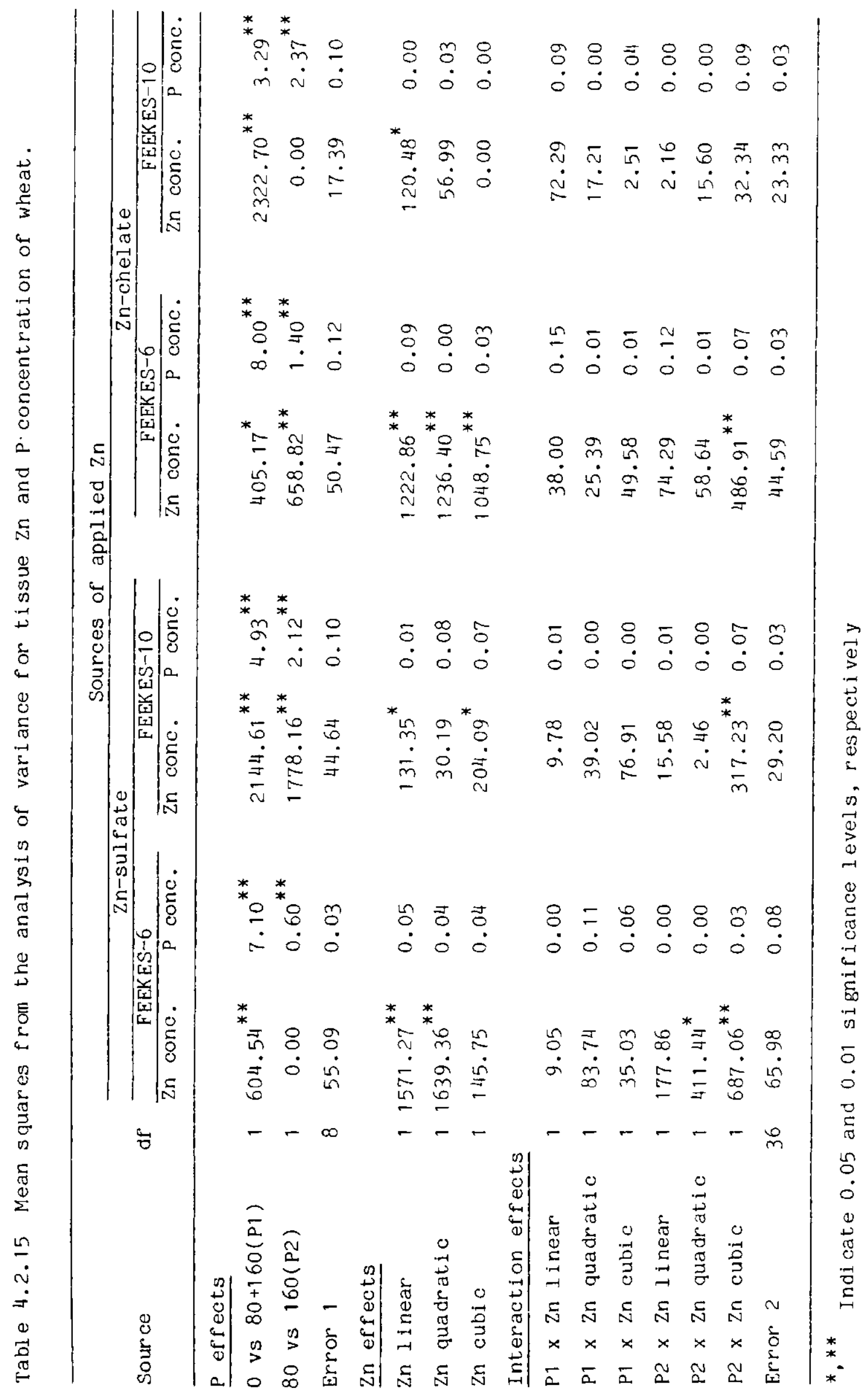


Table 4.2.16 Effect of $P$ applied in 1979 and foliarly applied $\mathrm{Zn}-$ chelate in 1984 on tissue $\mathrm{Zn}$ concentration at FEEKES 10 growth stage.

\begin{tabular}{|c|c|c|}
\hline \multicolumn{2}{|l|}{ Treatment } & \multirow{2}{*}{ EEEKES 10} \\
\hline $\mathrm{P}$ & $\mathrm{Zn}$ & \\
\hline$-\mathrm{kg} \mathrm{ha}^{-1}$ & - & $\mathrm{mg} \mathrm{kg}{ }^{-1}$ \\
\hline \multirow[t]{2}{*}{0} & 0 & 34.3 \\
\hline & $0.35 \mathrm{~T}^{\dagger}$ & 44.9 \\
\hline \multirow[t]{2}{*}{80} & 0 & 18.4 \\
\hline & $0.35 \mathrm{~T}$ & .32 .1 \\
\hline \multirow[t]{2}{*}{100} & 0 & 16.2 \\
\hline & $0.35 \mathrm{~T}$ & 28.4 \\
\hline
\end{tabular}

Statistical significance

Source

df

Mean square

P effects

0 vs $80+160(P \uparrow)$

1

$1669.53^{* *}$

80 vs $160(\mathrm{P} 2)$

1

43.51

Error 1

8

26.84

\section{Zn effects}

0 vs $0.35 T^{\dagger}(\mathrm{Zn})$

$11: 0.20^{* *}$

\section{Interaction effects}

P1 $\mathrm{X} \mathrm{Zn}$

9.20

P2 $\times \mathrm{Zn}$

2.80

Error 2

12

39.59

\footnotetext{
${ }^{\dagger}$ Zn-chelate applied at FEEKES 6 stage

** Indi cate 0.01 si gnificance 1 evel
} 
were no differences in the 2 n concentration of grain or straw between the 80 and $160 \mathrm{~kg} \mathrm{P} \mathrm{ha}{ }^{-1}$ treatments. Application of $\mathrm{Zn}$ to the soil either as Zn-sulfate or Zn-chelate increased $\mathrm{Zn}$ concentration in the grain but generally had no effect on the $\mathrm{Zn}$ levels in the straw (Tables $4.2 .17,4.2 .18,4.2 .20$ and 4.2.21). In contrast, foliarly applied $\mathrm{Zn}$ increased $\mathrm{Zn}$ concentrations in both grain and straw at maturity (Tables 4.2.19 and 4.2.22). This increase was independent of the growth stage at which foliar $\mathrm{Zn}$ was applied (Table 4.2.22). In the $0 \mathrm{~kg} \mathrm{Zn} \mathrm{ha}{ }^{-1}$ treatment total uptake of $\mathrm{Zn}$ into the above ground plant parts (grain + straw) decreased from $107.2 \mathrm{~g} \mathrm{Zn} \mathrm{ha}^{-1}$ in $0 \mathrm{~kg} \mathrm{P}$ $\mathrm{ha}^{-1}$ to 87.2 and $88.1 \mathrm{~g} \mathrm{Zn} \mathrm{ha}^{-1}$ in the 80 and $160 \mathrm{~kg} \mathrm{P} \mathrm{ha}^{-1}$ treatments, respectively. These decreases in the $\mathrm{zn}$ concentration of total above ground dry matter amounted to 27 and $35 \%$ for the corresponding $P$ treatments and can oniy be partly explained by the corresponding increase in total above ground dry matter yield of 10 and $32 \%$. Hence, a $P$ induced $Z n$ deficiency in this experiment can only be partiy explained by a dilution effect.

The significant $P X Z n$ interaction on the grain yield was also accompanied by a significant interaction on $\mathrm{Zn}$ uptake for the $\mathrm{Zn}-$ sulfate and foliar $\mathrm{Zn}$-chelate treatments (Tables 4.2.20 and 4.2.22). Zn uptake into the grain was increased onl y when $\mathrm{Zn}$ was applied in the presence of $\mathrm{P}$ (Tables 4.2 .18 and 4.2.19).

The concentration and uptake of $P$ into grain in all cases were affected significantly by both $P$ and $Z$ n rates (Tables 4.2 .17 to 4.2.22). A significant $P X \mathrm{Zn}$ interaction on $\mathrm{P}$ uptake into grain was evident both with soil and foliarly applied $\mathrm{Zn}$. 


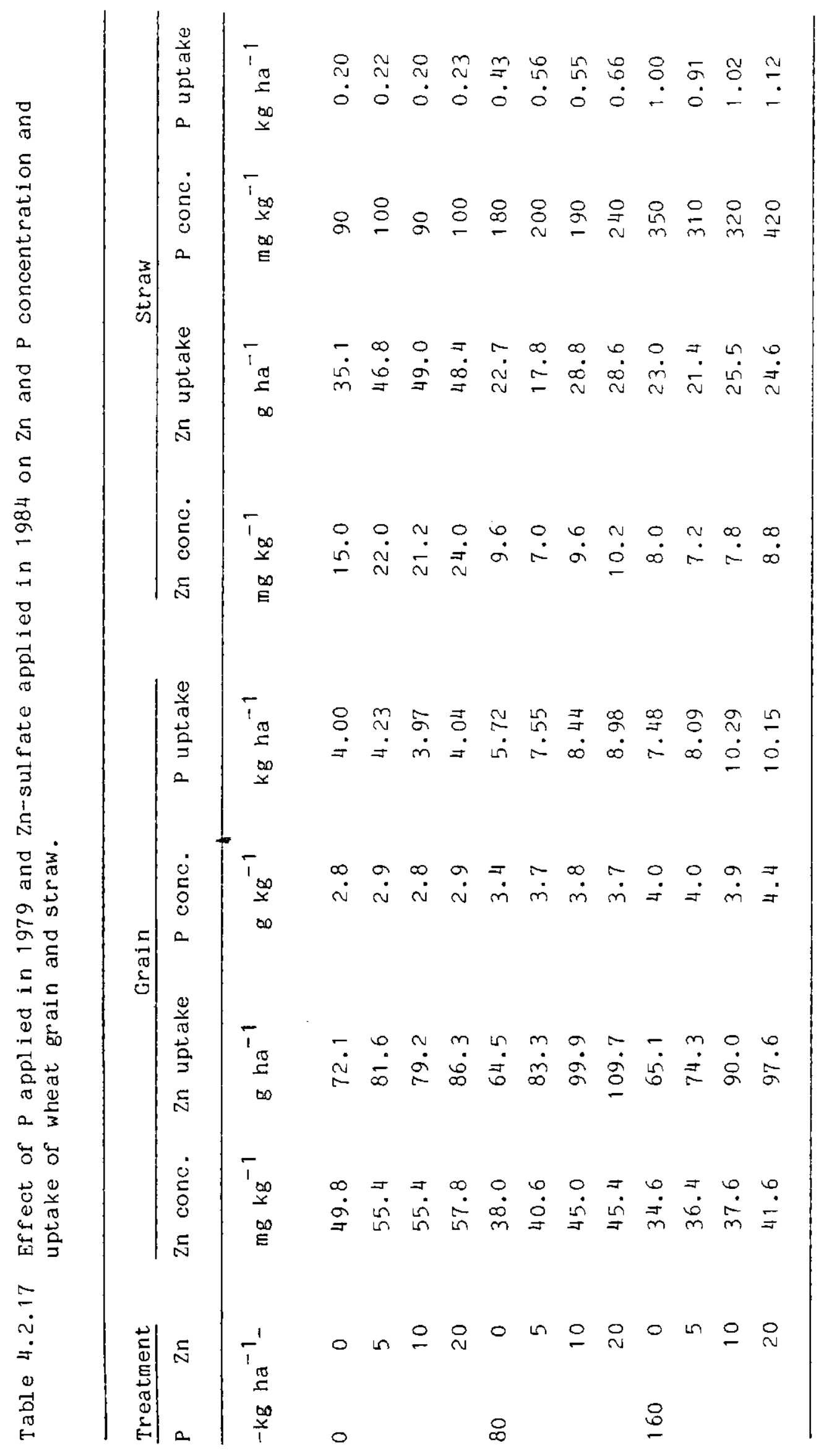




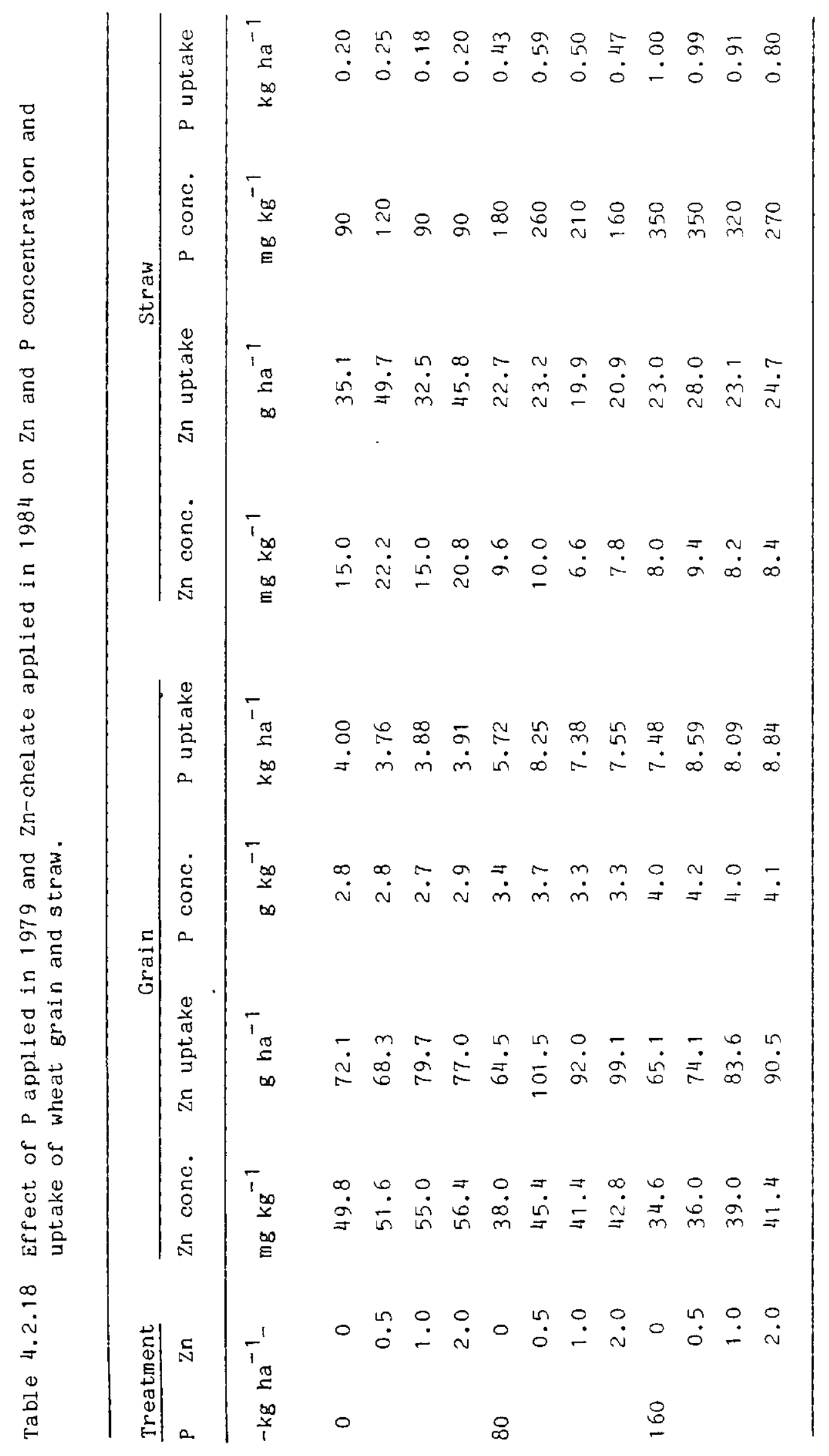









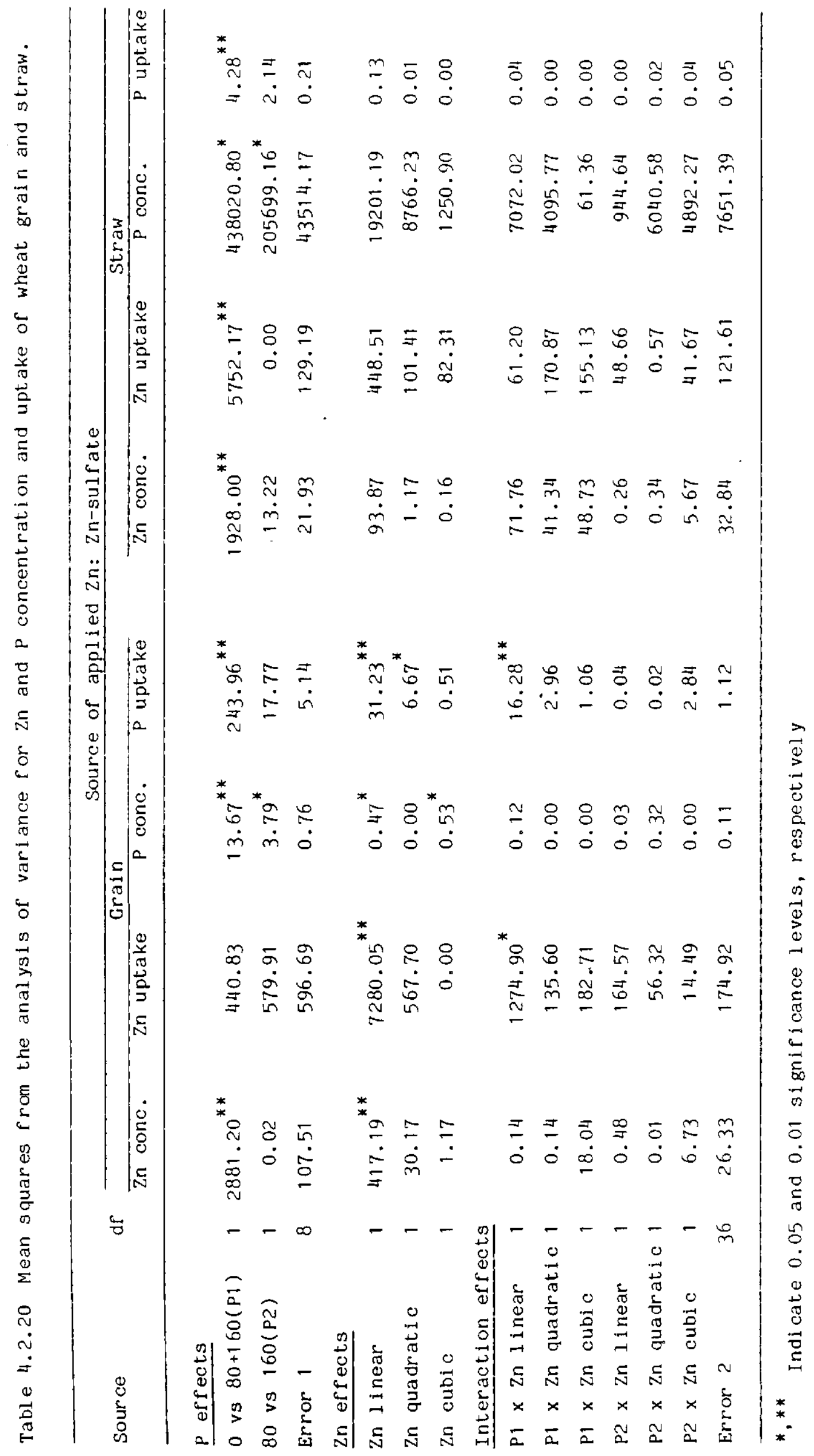




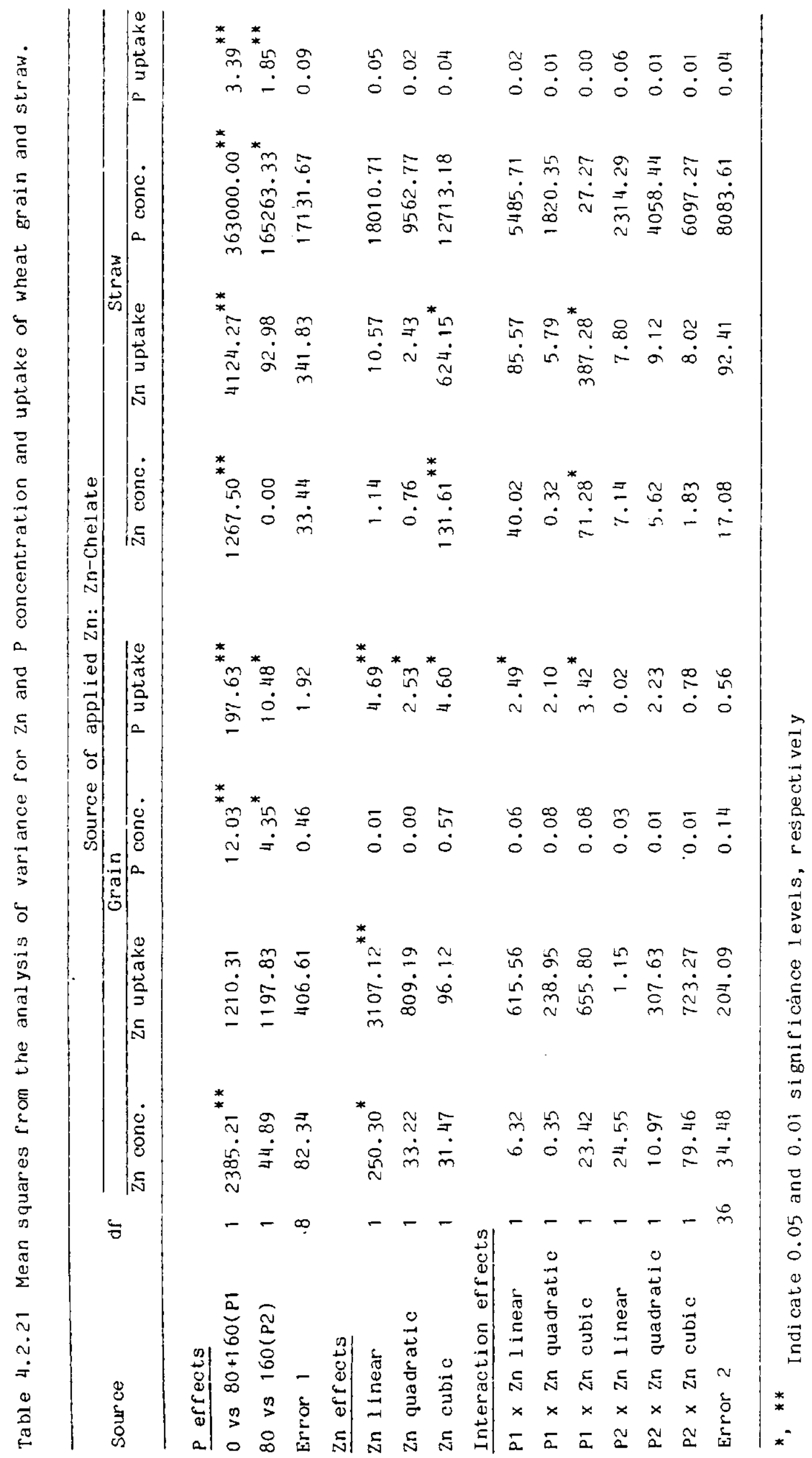




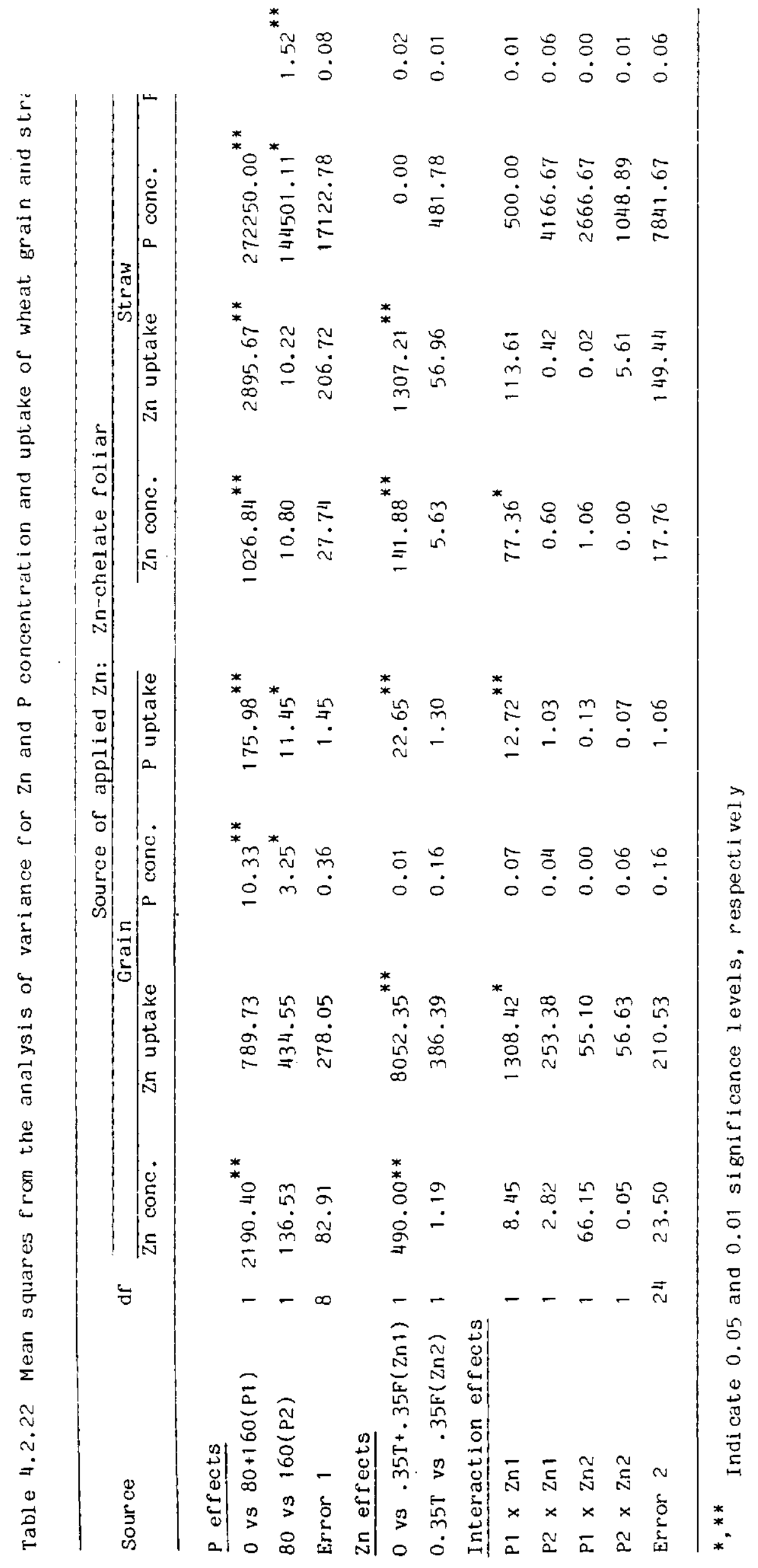




\subsubsection{Nature of $\mathrm{P} X \mathrm{Zn}$ interaction}

A number of possible explanations have been given for $P \times \mathrm{Zn}$ interaction. Bingham (1963) suggested that the interaction was a result of chemical reactions that occur in the soil. This theory was deemed unsatisfactory by Olsen (1972), since the increase of added $P$ to the soil did not cause a decrease in either water soluble or extractable soil $\mathrm{Zn}$. This possibility was also discounted in our experiment for the same reasons. DTPA-extractable in in the non-zn amended treatments varied between 0.96 and $1.02 \mathrm{mg} \mathrm{kg}^{-1}$ and was independent of the $P$ application rate.

Loneragan et al. (1982) observed that under conditions of high $P$ and low $Z$ n supply, $P$ is absorbed by roots and transported in such excess that it becomes toxic and produces symptoms resembling $\mathrm{zn}$ deficiency, while not changing $\mathrm{Zn}$ concentration in plant tops. The levels of $P$ in the tissue, grain and straw of wheat in this experiment were well below the toxic level (ozanne, 1980). Therefore, P toxicity was not a factor in this study. Moreover, high ievels of $P$ in this experiment decreased the concentration of $\mathrm{Zn}$ in $\mathrm{plant}$ tissue to near critical levels (Table 4.2.14).

Other explanations are based on the translocation of $\mathrm{Zn}$ from roots to shoots (Stukenholtz et al., 1966; Sharma et al., 1968; Safaya, 1976) or metabolic anomalies which are caused from a lack of equilibrium between two elements in the plants (Boawn and Leggett, 1964; Boawn and Brown, 1968; Millikan et al., 1968). The latter has been clarified through the work of Loneragan et al. (1982) who have shown that $P$-induced $Z n$ deficiency is not due to $Z n$ metabolism in the leaves, but rather to $P$ absorption and transport from roots. Infec- 
tion of roots with mycorrhizae has been reported to increase $2 n$ uptake by the host plant (Benson and Covey, 1976). Cooper and Tinker (1978) using ${ }^{65} \mathrm{Zn}$ associated this with direct uptake of $\mathrm{Zn}$ by vesiculararbuscular mycorrhizal (VAM) hyphae and subsequent translocation into the host. Further, it has been shown (Hayman, 1978; Tinker, 1980) that high levels of $P$ can inhibit infection of roots with VAM. Hence, it is possible that increased $P$ levels in the soil may lead to reduced Zn uptake via a reduction of VAM infection. More recently, Lambert et al. (1979), showed that P fertilization suppressed mycorrhizal uptake of $\mathrm{Zn}$ in corn and soybeans. Although translocation effects cannot be discounted in this experiment as a possible cause of reduced zn uptake with addition of 1 arge $P$ amounts, an attempt was made to identify the possible role of mycorrhizae in this interaction.

The effect of high $P$ application rates on the mycorrhizal infection of wheat roots at the completion of the experiment is shown in Figure 4.11. Low mycorrhizal infection was associated with large $P$ appl ication rates.

The most significant $f$ inding in this study that could lead to a possible involvement of mycorrhizae in the $P X \mathrm{Zn}$ interaction observed was the close relationship between $\mathrm{zn}$ levels in the above ground $\mathrm{pl}$ ant parts and mycorrhizal inf ection (Figure 4.12). Hence, high Zn I evels in the foliage, grain and straw were associated with higher $:$ mycorrhizal infection of wheat roots.

It would be difficult to single out any of the mechanisms described above as responsible for the $\mathrm{P} X \mathrm{Zn}$ interaction observed. However, a portion of the decrease in $\mathrm{Zn}$ levels is indeed due to dilution. The remaining portion could be of a physiological nature 

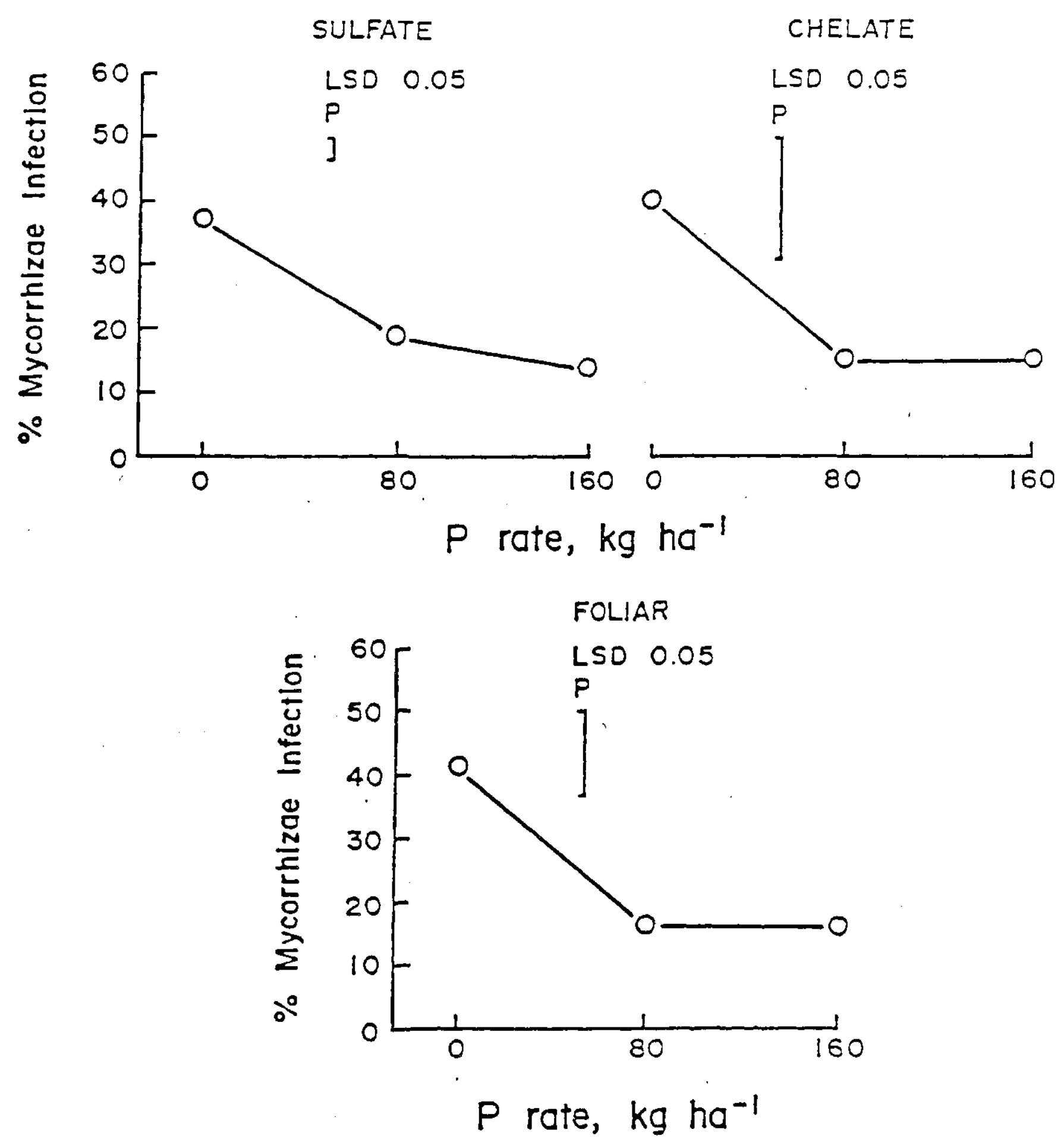

Figure 4.11 Relationship between mycorrhizal infection of wheat roots and rate of applied $P$. 


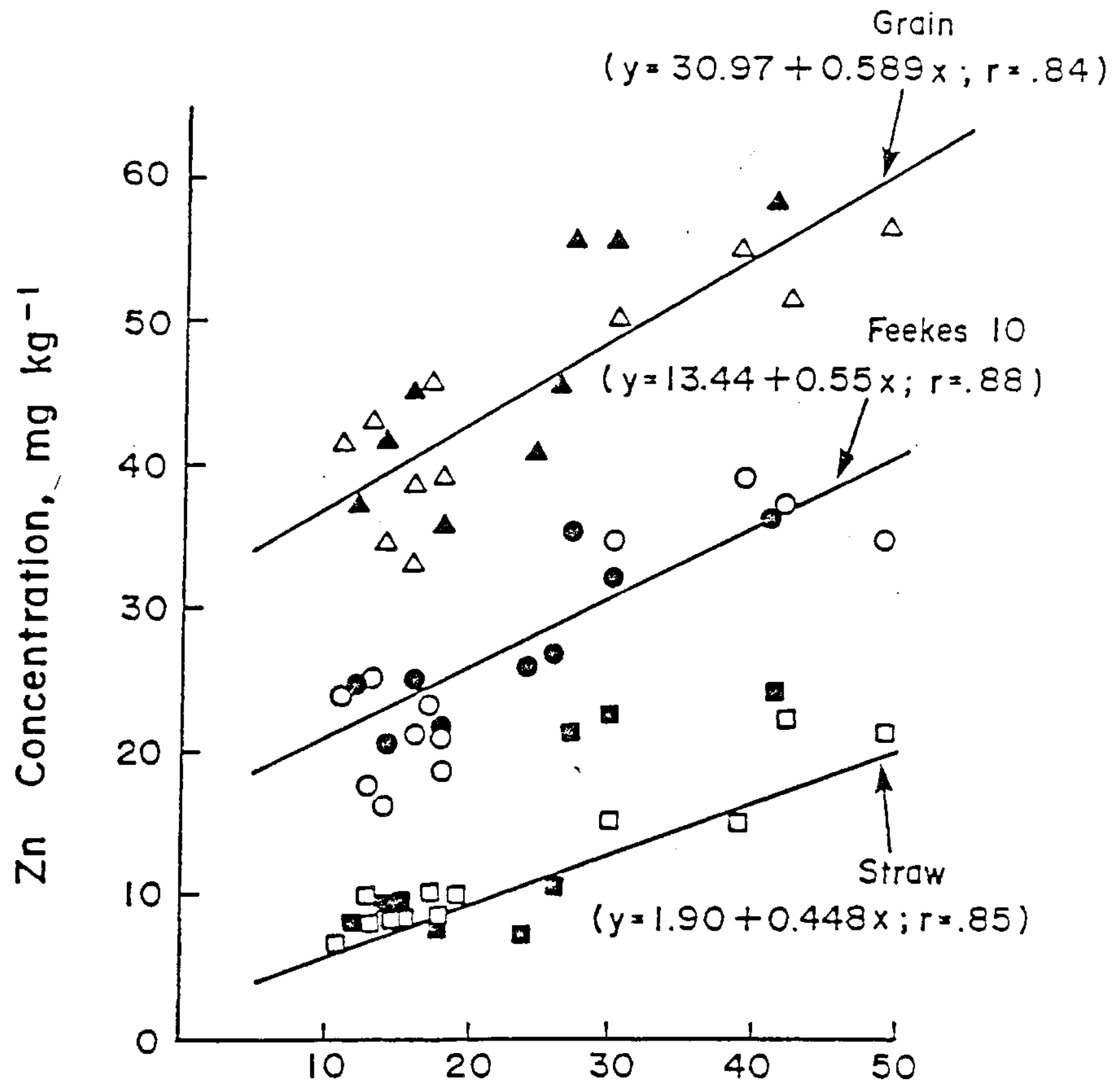

$\%$ Mycorrhizae Infection

Figure 4.12 Relationship between $\mathrm{Zn}$ levels in wheat plant tissue at FEEKES 10 and grain and straw and mycorrrhizal infection of corresponding roots (open symbols indicate $Z n$-sulfate and darkened $\mathrm{Zn}$-chelate treatments). 
enharced by reduced mycorrhizal irfection in the roots of plarts grown in treatments of high $P$ application rates.

\subsubsection{P X Zn interaction in beans \\ 4.2.3.1 Yields}

Dry matter yields (DMY) of all plant parts at both growth stages except the tops of beans grown on the Meota soil responded curvilinearly to $P$ additions in all three soils (Tables 4.2 .23 to 4.2.25). Maximum mean DMY in all cases was obtained with the addition of $40 \mathrm{mg} \mathrm{P} \mathrm{kg}^{-1}$. Response of DMY to $\mathrm{Zn}$ applications was not the same in all cases but was a function of both the soil and plant part. Hence, significant DMY increases due to $\mathrm{Zn}$ were obtained in the Sutherland (Table 4.2.23) and Carrot River (Table 4.2.24) soils for the above ground plant parts only.

Application of $\mathrm{Zn}$ alone without $\mathrm{P}$ application had no effect on DMY of beans. In contrast, significant DMY increases due to $P$ application in the absence of $\mathrm{Zn}$ were observed in all three soils. The $P X \mathrm{Zn}$ interaction on DMY of above ground plant parts was significant for the Sutherland and Carrot River soils only (Tables 4.2.23 and 4.2.24). This interaction was expressed by 1 arger yield responses to $\mathrm{P}$ when $\mathrm{Zn}$ was applied and $\mathrm{l}$ arger responses to $\mathrm{Zn}$ when $\mathrm{P}$ was applied.

\subsubsection{Zinc concentration and uptake in bean plants}

The $\mathrm{Zn}$ concentration in the bean roots and tops at $1 / 10$ bloom stage and in the roots, straw and seeds at maturity are presented in Tables $4.2 .26,4.2 .27$ and 4.2 .28 for the Sutherland, Carrot $R i v e r$ and 
Table 4.2.23 Effect of $P$ and $Z$ n application on the yield of beans grown on sutherland soil.

\begin{tabular}{|c|c|c|c|c|c|c|}
\hline \multicolumn{2}{|c|}{ Treatment } & \multicolumn{2}{|c|}{$1 / 10$ bloom stage } & \multicolumn{3}{|c|}{ Maturity } \\
\hline$P$ & $\mathrm{Zn}$ & Roots & Tops & Roots & Seeds & Straw \\
\hline \multicolumn{2}{|c|}{$\mathrm{mg} \mathrm{kg} \mathrm{kg}^{-1}$} & & & $g$ pot $^{-1}$ & & \\
\hline 0 & 0 & 0.30 & $1 \cdot 30$ & 0.53 & 1.55 & 2.05 \\
\hline & 5 & 0.33 & 1.20 & 0.53 & 1.40 & 2.00 \\
\hline & 10 & 0.30 & 1.10 & 0.48 & 1.35 & 2.00 \\
\hline \multirow[t]{3}{*}{40} & 0 & 0.60 & 2.15 & 0.98 & 4.15 & 3.98 \\
\hline & 5 & 0.63 & 2.78 & 1.05 & 5.48 & 4.98 \\
\hline & 10 & 0.60 & 2.75 & 0.95 & 5.45 & 5.23 \\
\hline \multirow[t]{3}{*}{80} & 0 & 0.58 & 1.85 & 1.10 & 4.25 & 4.05 \\
\hline & 5 & 0.65 & 2.93 & 0.95 & 5.35 & 5.33 \\
\hline & 10 & 0.65 & 3.05 & 0.95 & 5.55 & 5.30 \\
\hline \multirow[t]{3}{*}{160} & 0 & 0.55 & 1.93 & 1.03 & 4.00 & 3.98 \\
\hline & 5 & 0.55 & 3.15 & 1.08 & 5.70 & 5.65 \\
\hline & 10 & 0.63 & 3.15 & 1.05 & 5.30 & 4.90 \\
\hline
\end{tabular}

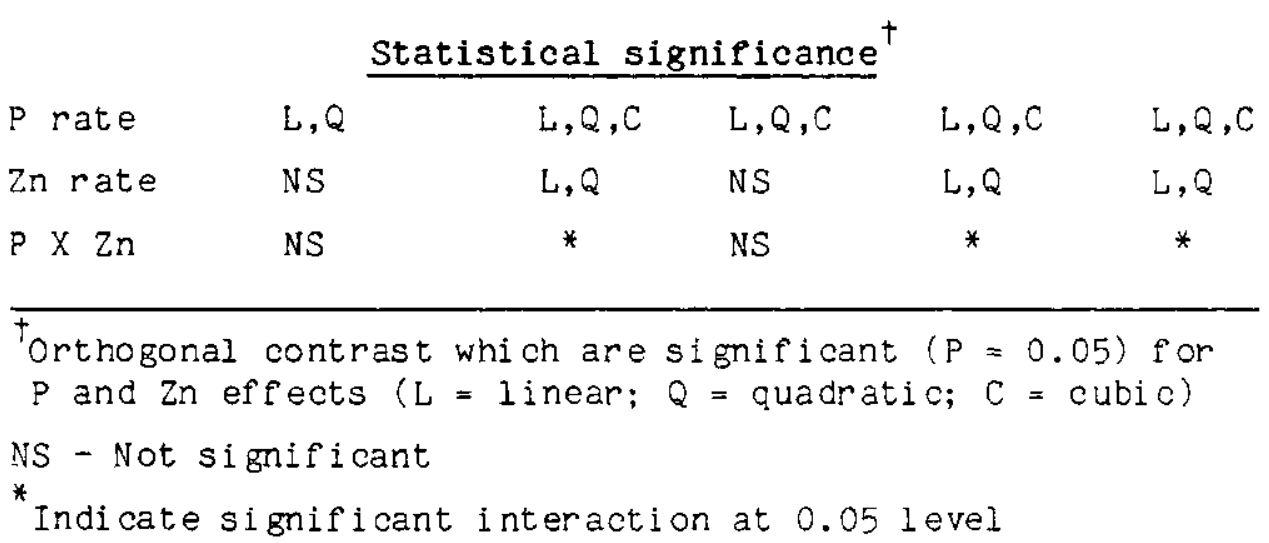


Table 4.2.24 Effect of $P$ and $z$ n application on the yield of beans grown on Carrot River soil.

\begin{tabular}{|c|c|c|c|c|c|c|}
\hline \multicolumn{2}{|c|}{ Treatment } & \multicolumn{2}{|c|}{$1 / 10$ bloom stage } & \multicolumn{3}{|c|}{ Maturity } \\
\hline$P$ & $\mathrm{Zn}$ & Roots & Tops & Roots & Seeds & Straw \\
\hline \multicolumn{2}{|c|}{$m g \mathrm{~kg}^{-1}$} & - & 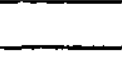 & $g \operatorname{pot}^{-1}$ & - & ـــــــــ \\
\hline 0 & 0 & 0.30 & 1.63 & 0.85 & 1.75 & 2.93 \\
\hline & 5 & 0.55 & 1.95 & 0.88 & 1.83 & 3.20 \\
\hline \multirow[t]{2}{*}{40} & 0 & 0.75 & 2.50 & 1.20 & 4.45 & 4.40 \\
\hline & 5 & 0.68 & 3.08 & 1.15 & 5.63 & 5.25 \\
\hline \multirow[t]{2}{*}{80} & 0 & 0.70 & 2.35 & 1.25 & 4.08 & 4.45 \\
\hline & 5 & 0.68 & 3.20 & 1.20 & 6.28 & 5.40 \\
\hline \multirow[t]{2}{*}{160} & 0 & 0.68 & 2.30 & 1.18 & 4.00 & 4.38 \\
\hline & 5 & 0.75 & 3.33 & 1.26 & 6.03 & 5.63 \\
\hline
\end{tabular}

$\underline{\text { Statistical significance }}^{\dagger}$

\begin{tabular}{|c|c|c|c|c|c|}
\hline P rate & $L, Q$ & $L, Q, C$ & $L, Q$ & $L, Q, C$ & $L, Q$ \\
\hline Zn rate & NS & $*$ & NS & * & $*$ \\
\hline $\mathrm{P} \times \mathrm{Zn}$ & NS & * & NS & * & NS \\
\hline \multicolumn{6}{|c|}{$\begin{array}{l}\text { Orthogonal contrast which are significant }(P=0.05) \text { for } \\
P \text { effects }(L=\text { linear; } Q=\text { quadratic; } C=c \text { cubic) } \\
\text { NS - Not significant } \\
\text { * Indicate } 0.05 \text { significance level for } Z n \text { and interaction } \\
\text { effects }\end{array}$} \\
\hline
\end{tabular}


Table 4.2.25 Effect of $P$ and $Z n$ application on the yield of beans grown on Meota soil.

\begin{tabular}{|c|c|c|c|c|c|c|}
\hline \multicolumn{2}{|c|}{ Treatment } & \multicolumn{2}{|c|}{$1 / 10$ bloom stage } & \multicolumn{3}{|c|}{ Maturity } \\
\hline$P$ & $2 n$ & Roots & Tops & Roots & Seeds & Straw \\
\hline \multicolumn{2}{|c|}{$\mathrm{mg} \mathrm{kg}^{-1}$} & $\longrightarrow$ & 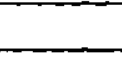 & $g$ pot $^{-1}$ & & \\
\hline 0 & 0 & 0.50 & 2.40 & 1.58 & 5.85 & 5.53 \\
\hline & 5 & 0.43 & 2.20 & 1.58 & 6.00 & 5.73 \\
\hline \multirow[t]{2}{*}{40} & 0 & 0.70 & 2.93 & 1.98 & 8.20 & 6.90 \\
\hline & 5 & 0.70 & 3.13 & 2.00 & 8.00 & 7.15 \\
\hline \multirow[t]{2}{*}{80} & 0 & 0.70 & 2.88 & 1.95 & 8.23 & 7.28 \\
\hline & 5 & 0.73 & 3.10 & 2.03 & 8.48 & 7.78 \\
\hline \multirow[t]{2}{*}{160} & 0 & 0.68 & 3.28 & 1.90 & 7.98 & 7.33 \\
\hline & 5 & 0.83 & 3.40 & 1.98 & 8.00 & 7.43 \\
\hline
\end{tabular}

\section{Statistical significance $^{\dagger}$}

\begin{tabular}{|c|c|c|c|c|c|}
\hline P rate & $L, Q$ & $L$ & $L, Q$ & $L, Q$ & $L, Q$ \\
\hline Zn rate & NS & NS & NS & NS & NS \\
\hline$P \times Z n$ & NS & NS & NS & NS & NS \\
\hline
\end{tabular}


Table 4.2.26 Effect of $P$ and $Z n$ application on the $\mathrm{Zn}$ concentration of beans grown on Sutherland soil.

\begin{tabular}{|c|c|c|c|c|c|c|}
\hline \multicolumn{2}{|c|}{ Treatment } & \multicolumn{2}{|c|}{$1 / 10$ bloom stage } & \multicolumn{3}{|c|}{ Maturity } \\
\hline$P$ & $Z n$ & Roots & Tops & Roots & Seeds & Straw \\
\hline \multicolumn{2}{|c|}{$\mathrm{mg} \mathrm{kg}{ }^{-1}$} & & & $m g \mathrm{~kg}^{-1}$ & & \\
\hline \multirow[t]{3}{*}{0} & 0 & 26.0 & 19.4 & 24.6 & 29.9 & 18.5 \\
\hline & 5 & 44.5 & 37.8 & 39.6 & 37.9 & 27.3 \\
\hline & 10 & 63.8 & 41.4 & 49.4 & 48.7 & 30.4 \\
\hline \multirow[t]{3}{*}{40} & 0 & 32.5 & 13.8 & 28.9 & 22.9 & 12.8 \\
\hline & 5 & 34.0 & 21.9 & 30.1 & 22.9 & 13.9 \\
\hline & 10 & 41.0 & 26.9 & 37.9 & 26.1 & 16.5 \\
\hline \multirow[t]{3}{*}{80} & 0 & 38.2 & 13.2 & $27 \cdot 5$ & 19.8 & 10.0 \\
\hline & 5 & 34.6 & 21.9 & 34.3 & 22.8 & 16.2 \\
\hline & 10 & 37.9 & 24.7 & 38.7 & 26.5 & 18.7 \\
\hline \multirow[t]{3}{*}{160} & 0 & 39.3 & 10.5 & 29.1 & 20.5 & 7.8 \\
\hline & 5 & 39.1 & 21.6 & 31.5 & 24.8 & 15.2 \\
\hline & 10 & 37.2 & 26.3 & 38.6 & 28.2 & 20.0 \\
\hline
\end{tabular}

Statistical significance $^{\dagger}$

\begin{tabular}{|c|c|c|c|c|c|}
\hline P rate & $L, Q, C$ & $L, Q, C$ & $L, Q$ & $L, Q, C$ & $L, Q, C$ \\
\hline Zn rate & L & $L, Q$ & $L$ & $\mathrm{~L}$ & L \\
\hline$P \times Z n$ & * & * & $*$ & * & * \\
\hline
\end{tabular}

Forthogonal contrast which are significant $(P=0.05)$ for $P$ and $\mathrm{Zn}$ effects ( $\mathrm{L}=$ linear; $Q=$ quadratic; $C=$ cubi $C$ )

* Indicate significant interaction at 0.05 level 
Table 4.2.27 Effect of $P$ and $Z n$ application on the $Z n$ concentration of beans grown on Carrot River soil.

\begin{tabular}{|c|c|c|c|c|c|c|}
\hline \multicolumn{2}{|c|}{ Treatment } & \multicolumn{2}{|c|}{$1 / 10$ bloom stage } & \multicolumn{3}{|c|}{ Maturity } \\
\hline$P$ & $\mathrm{Zn}$ & Roots & Tops & Roots & Seeds & Straw \\
\hline \multicolumn{2}{|c|}{$\mathrm{mg} \mathrm{kg} \mathrm{kg}^{-1}$} & - & & $m g \mathrm{~kg}^{-1}$ & & 5 \\
\hline \multirow[t]{2}{*}{0} & 0 & 33.7 & 20.3 & 27.2 & $31 \cdot 3$ & 18.7 \\
\hline & 5 & 78.9 & 40.5 & 51.5 & 47.1 & 32.8 \\
\hline \multirow[t]{2}{*}{40} & 0 & 30.0 & 14.7 & 29.1 & 25.8 & 13.7 \\
\hline & 5 & 67.8 & 30.1 & 50.6 & 31.2 & 26.6 \\
\hline \multirow[t]{2}{*}{80} & 0 & 35.8 & 13.7 & 33.5 & 25.9 & 11.7 \\
\hline & 5 & 77.9 & 29.7 & 53.5 & 30.5 & 25.9 \\
\hline \multirow[t]{2}{*}{160} & 0 & 44.8 & 11.2 & 36.4 & 26.3 & 11.0 \\
\hline & 5 & 67.4 & 29.8 & 53.6 & 33.1 & 26.0 \\
\hline
\end{tabular}

Statistical significance $^{\dagger}$

\begin{tabular}{|c|c|c|c|c|c|}
\hline P rate & $\mathrm{C}$ & $L, Q, C$ & $Q, C$ & $\mathrm{~L}, \mathrm{Q}$ & $L, Q$ \\
\hline Zn rate & * & * & * & * & $*$ \\
\hline$P X \mathrm{Zn}$ & * & * & $*$ & NS & NS \\
\hline \multicolumn{6}{|c|}{$\begin{array}{l}\text { Torthogonal contrast which are significant }(P=0.05) \text { for } \\
P \text { effects }(L=\text { linear; } Q=\text { quadratic; } C=c \text { ubi } C)\end{array}$} \\
\hline
\end{tabular}


Table 4.2.28 Effect of $P$ and $z$ n application on the $z$ n concentration of beans grown on Meota soil.

\begin{tabular}{|c|c|c|c|c|c|c|}
\hline \multicolumn{2}{|c|}{ Treatment } & \multicolumn{2}{|c|}{$1 / 10$ bloom stage } & \multicolumn{3}{|c|}{ Maturity } \\
\hline$P$ & $\mathrm{Zn}$ & Roots & Tops & Roots & Seeds & Straw \\
\hline \multicolumn{2}{|c|}{$\mathrm{mg} \mathrm{kg}{ }^{-1}$} & - & & $\mathrm{mg} \mathrm{kg} \mathrm{kg}^{-1}$ & & $\ldots$ \\
\hline 0 & 0 & 35.2 & 20.9 & 35.9 & 22.4 & 14.3 \\
\hline & 5 & 60.5 & 30.5 & 43.6 & 28.1 & 14.0 \\
\hline \multirow[t]{2}{*}{40} & 0 & 30.9 & 20.8 & 34.0 & 19.5 & 7.8 \\
\hline & 5 & 61.6 & 27.1 & 45.1 & 22.3 & 11.8 \\
\hline \multirow[t]{2}{*}{80} & 0 & 31.7 & 20.7 & 33.1 & 18.9 & $7 \cdot 3$ \\
\hline & 5 & 59.3 & $27 \cdot 3$ & 45.3 & 21.1 & 11.6 \\
\hline \multirow[t]{2}{*}{160} & 0 & $31 \cdot 5$ & 21.4 & 34.0 & 22.1 & 8.4 \\
\hline & 5 & 62.3 & 30.4 & 49.0 & 23.3 & 11.9 \\
\hline
\end{tabular}

$\underline{\text { Statistical significance }}^{\dagger}$

\begin{tabular}{|c|c|c|c|c|c|}
\hline$P$ rate & NS & $\mathrm{Q}$ & $Q$ & $Q$ & $L, Q$ \\
\hline Zn rate & * & * & * & * & * \\
\hline$P X Z n$ & NS & NS & NS & NS & NS \\
\hline \multicolumn{6}{|c|}{$\begin{array}{l}\text { Torthogonal contrast which are significant }(P=0.05) \text { for } \\
P \text { effects }(L=1 \text { inear; } Q=\text { quadratic; } C=\text { cubi } C \text { ) }\end{array}$} \\
\hline
\end{tabular}


Meota soils, respectively.

The mean effect of either $P$ or $Z n$ application on the $\mathrm{Zn}$ concentration in all plant parts was significant at $P<0.05$ (Tables 4.2 .26 to 4.2.28) in all soils except for the roots of beans grown on the Meota soil at $1 / 10$ bloom stage (Table 4.2.28). The expression of the mean effect, however, varied among soils and plant parts. In the Sutherland. and Carrot River soils, the $\mathrm{Zn}$ concentration in the bean tops at $1 / 10$ bloom stage was sharply reduced with the addition of 40 mg $P \mathrm{~kg}^{-1}$ of soil and remained more or less constant at higher $P$ application rates (Tabies 4.2 .26 and 4.2.27). A similar trend was obtained for the roots of the beans at $1 / 10$ bloom stage on the Sutherland soil only.

The mean effect of $P$ on $Z n$ concentration in the tops of beans at $1 / 10$ bloom stage on the Meota soil (Table 4.2.28) and the roots on the Carrot River soil (Table 4.2.27) was less pronounced.

At maturity, $Z n$ levels in the straw of plants grown in all soils were decreased sharply with $40 \mathrm{mg}$ applied $\mathrm{p} \mathrm{kg}^{-1}$ of soil and remained more or less unaffected thereafter. A similar trend was also obtained for the seeds of plants grown on the Sutherland and Carrot River soils (Table 4.2 .26 and 4.2 .27 ) and the roots on the Sutherland soil (Table 4.2.26). In the remaining cases the effect of $P$ on $\mathrm{Zn}$ concentration was very small.

A significant $P \times 2 n$ interaction was obtained in the Sutherland and Carrot River soils only (Tables 4.2 .26 and 4.2.27). A consideration of the $\mathrm{Zn}$ concentration in the tops of beans grown on these soils provides an insight into the $P X \mathrm{Zn}$ interaction observed for DMY. Responses of DMY to $\mathrm{Zn}$ in the presence of added $P$ were a 
consequence of the low $2 n$ concentration in the tops of bean plants (Tables 4.2.26 and 4.2.27). For example, addition of $40 \mathrm{mg}^{\mathrm{P}} \mathrm{kg}^{-1}$ of soil caused a drop of $Z$ n concentration of tops at $1 / 10$ bloom stage from 19.4 and 20.3 to 13.8 and $14.7 \mathrm{mg} \mathrm{zn} \mathrm{kg}^{-1}$ in the sutherland and Carrot River soils, respectively (Tables 4.2 .26 and 4.2 .27 ). In contrast, $P$ application on the Meota soil had no pronounced effect on $\mathrm{Zn}$ concentration in tops ( $T a b l e 4.2 .28$ ). The non-occurrence of $P X \mathrm{Zn}$ interaction in the Meota soil can be explained since this soil apparently had enough "available" $\mathrm{Zn}$ to meet the requirement of growing plants.

The hypotheses that the decrease in the concentration of $\mathrm{Zn}$ in different plant parts of beans grown on the Sutherland and Carrot River soils was due to a dilution effect was tested by calculating total uptake of $\mathrm{zn}$ by beans (Tables 4.2.29 to 4.2.31). Although application of $P$ increased the yield of beans at ali levels of applied Zn in the Sutherland and Carrot River soils (Tables 4.2.23 and 4.2.24), the uptake of $\mathrm{Zn}$ into different plant parts increased with increasing rates of applied $\mathrm{P}$ at 5 or $10 \mathrm{mg} \mathrm{Zn} \mathrm{kg}^{-1}$ of applied $\mathrm{Zn}$ only. A critical examination of the $z$ n uptake into the above ground plant parts of non-Zn treatment reveals that $40 \mathrm{mg} \mathrm{P} \mathrm{kg}^{-1}$ causes an increase in $\mathrm{Zn}$ uptake, whereas there was sharp reduction in $\mathrm{Zn}$ uptake at 80 and $160 \mathrm{mg} \mathrm{P} \mathrm{kg}$ of applied $P$ (Tables 4.2 .29 and 4.2 .30 ). However, there was an increase in $\mathrm{Zn}$ uptake by roots with increasing $\mathrm{P}$ applications, indicating a reduced translocation to the above ground plant parts. Hence, both plant dilution effects and restricted translocation of $\mathrm{Zn}$ from roots to above ground plant parts seem to be the factor responsible for $\mathrm{p}$-induced $\mathrm{Zn}$ deficiency in the Sutherland 
Table 4.2.29 Effect of $P$ and $Z n$ application on the $\mathrm{Zn}$ uptake of beans grown on Sutherland soil.

\begin{tabular}{|c|c|c|c|c|c|c|}
\hline \multicolumn{2}{|c|}{ Treatment } & \multicolumn{2}{|c|}{$1 / 10$ bioom stage } & \multicolumn{3}{|c|}{ Maturity } \\
\hline$P$ & $2 n$ & Roots & Tops & Roots & Seeds & Straw \\
\hline \multicolumn{2}{|c|}{$\mathrm{mg} \mathrm{kg} \mathrm{kg}^{-1}$} & - & - & $\mu g$ pot $^{-1}$ & & $\ldots$ \\
\hline \multirow[t]{3}{*}{0} & 0 & 7.78 & 25.22 & 12.93 & 46.05 & 37.87 \\
\hline & 5 & 14.43 & 45.78 & 20.74 & 53.35 & 54.16 \\
\hline & 10 & 19.02 & 42.94 & 23.42 & 65.76 & 61.31 \\
\hline \multirow[t]{3}{*}{40} & 0 & 19.24 & 29.46 & 28.21 & 94.89 & 50.87 \\
\hline & 5 & .21 .35 & 60.43 & 31.55 & 124.63 & 68.64 \\
\hline & 10 & 24.41 & 73.69 & 35.94 & 140.84 & 86.67 \\
\hline \multirow[t]{3}{*}{80} & 0 & 22.01 & 24.62 & 30.25 & 84.18 & 40.59 \\
\hline & 5 & 22.44 & 63.81 & 32.69 & 121.99 & 85.61 \\
\hline & 10 & 24.94 & 75.12 & 36.58 & $: 46.13$ & 98.79 \\
\hline \multirow[t]{3}{*}{160} & 0 & 21.53 & 20.16 & 29.48 & 82.04 & 31.19 \\
\hline & 5 & 23.94 & 68.45 & 33.57 & 140.67 & 90.90 \\
\hline & 10 & 26.29 & 82.88 & 40.32 & 150.02 & 97.57 \\
\hline
\end{tabular}

\section{Statistical significance $^{\dagger}$}

$\begin{array}{llllll}P \text { rate } & \text { L,Q } & \text { L,Q } & \text { L, Q, C } & \text { L, Q, C } & \text { L, Q } \\ \text { Zn rate } & \text { L } & \text { L, Q } & \text { L } & \text { L } & \text { L } \\ P X \text { Zn } & \text { NS } & * & \text { NS } & * & *\end{array}$

\footnotetext{
†rthogonal contrast which are significant $(P=0.05)$ for $P$ and $Z n$ effects ( $L=$ Iinear; $Q=$ quadrati $c ; C=$ cubi $C$ ) NS - Not significant

* Indicate significant interaction at 0.051 evel
} 
Table 4.2.30 Effect of $P$ and $z$ n application on the $\mathrm{Zn}$ uptake of beans grown on Carrot River soil.

\begin{tabular}{|c|c|c|c|c|c|c|}
\hline \multicolumn{2}{|c|}{ Treatment } & \multicolumn{2}{|c|}{$1 / 10$ bloom stage } & \multicolumn{3}{|c|}{ Maturity } \\
\hline$P$ & $\mathrm{Zn}$ & Roots & Tops & Roots & Seeds & Straw \\
\hline \multicolumn{2}{|c|}{$m g \mathrm{~kg}^{-1}$} & 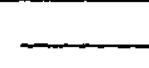 & $-\ldots$ & $\mu g \operatorname{pot}^{-1}$ & & \\
\hline 0 & 0 & 10.10 & 32.91 & 23.12 & 54.38 & 54.72 \\
\hline & 5 & 43.37 & 78.66 & 45.45 & 86.56 & 103.18 \\
\hline \multirow[t]{2}{*}{40} & 0 & 22.50 & 36.38 & 34.92 & 194.70 & 60.67 \\
\hline & 5 & 45.31 & 92.48 & 58.50 & 175.51 & 137.89 \\
\hline \multirow[t]{2}{*}{80} & 0 & 25.02 & 32.18 & 41.42 & 106.96 & 52.26 \\
\hline & 5 & 52.28 & 94.79 & 66.88 & 192.05 & 138.72 \\
\hline \multirow[t]{2}{*}{160} & 0 & 30.18 & 25.49 & 43.05 & 105.19 & 48.54 \\
\hline & 5 & 50.64 & 98.81 & 66.94 & 199.05 & 143.30 \\
\hline
\end{tabular}

Statistical significance $^{\dagger}$

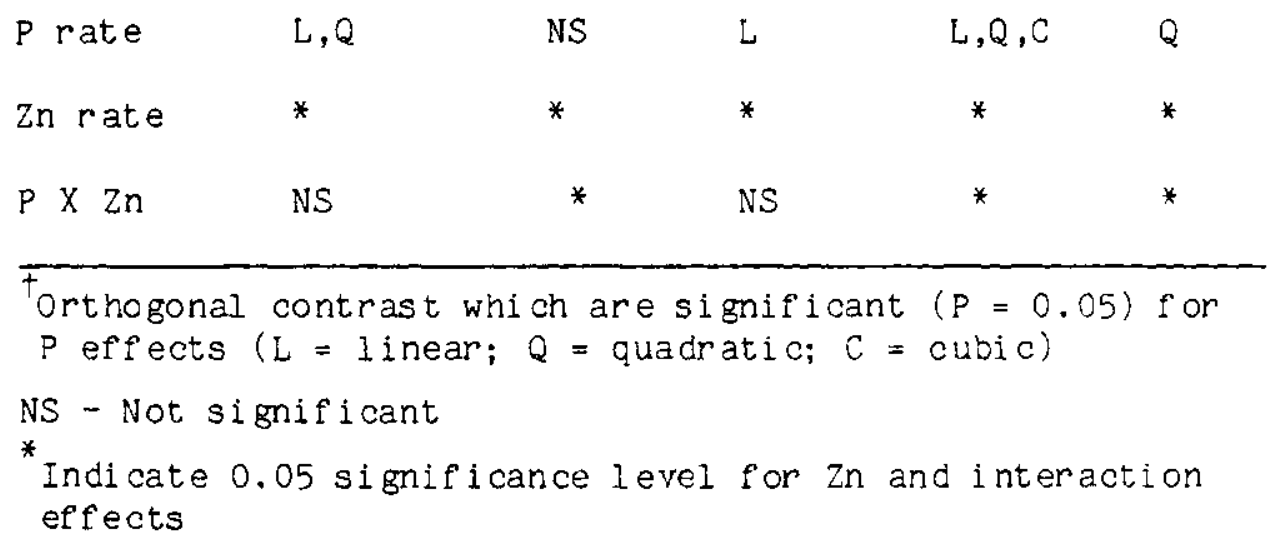


Table 4.2.31 Effect of $P$ and $Z n$ application on the $\mathrm{Zn}$ uptake of beans grown on Meota soil.

\begin{tabular}{|c|c|c|c|c|c|c|}
\hline \multicolumn{2}{|c|}{ Treatment } & \multicolumn{2}{|c|}{$1 / 10$ bloom stage } & \multicolumn{3}{|c|}{ Maturity } \\
\hline$P$ & $\mathrm{Zn}$ & Roots & Tops & Roots & Seeds & Straw \\
\hline \multicolumn{2}{|c|}{$\mathrm{mg} \mathrm{kg} \mathrm{kg}^{-1}$} & $\cdots$ & - & \multirow{2}{*}{$\begin{array}{c}\mu \mathrm{g} \text { pot }^{-1} \\
56.59\end{array}$} & & - \\
\hline 0 & 0 & 17.62 & 50.19 & & 131.28 & 78.42 \\
\hline & 5 & 25.51 & 67.09 & 68.81 & 167.87 & 80.19 \\
\hline \multirow[t]{2}{*}{40} & 0 & 21.67 & 60.69 & 67.11 & 160.67 & 53.86 \\
\hline & 5 & 43.21 & 83.79 & 89.92 & $\cdot 178.21$ & 85.35 \\
\hline \multirow[t]{2}{*}{80} & 0 & 22.16 & 59.58 & 64.70 & 152.64 & 53.39 \\
\hline & 5 & 43.59 & 84.64 & 91.62 & 179.16 & 86.45 \\
\hline \multirow[t]{2}{*}{160} & 0 & 22.10 & 70.10 & 64.32 & 176.40 & 60.94 \\
\hline & 5 & 52.20 & 99.33 & 96.62 & 182.15 & 86.62 \\
\hline
\end{tabular}

\section{Statistical significance $^{\dagger}$}

$\begin{array}{llllll}\text { P rate } & \text { L } & \text { L } & \text { L } & \text { L } & \text { NS } \\ \text { Zn rate } & * & * & * & * & * \\ \text { P X Zn } & \text { NS } & \text { NS } & \text { NS } & \text { NS } & *\end{array}$

\footnotetext{
Torthogonal contrast which are significant $(P=0.05)$ for $P$ effects $(L=l$ inear $)$

NS - Not significant

* Indicates 0.05 significance level for $Z n$ and interaction ef fects
} 
and Carrot River soils. Restricted translocation of 7 f from roots to tops responsible for p-induced $Z$ n deficiency has also been reported by Stukenholtz et al. (1966) and Sharma et al. (1968).

At high levels of $P$, the retention of more $\mathrm{Zn}$ in roots was probably due to the increased binding of $2 n$ in root cell walls, resulting in less $\mathrm{Zn}$ available for transportation to the upper portion, as reported by Youngdahl et al. (1977). The observation that soils high in $2 n$ or soils that have been fertilized with $2 n$ do not show the $P$-induced $Z n$ deficiency can be explained, since once the binding sites in the cell walls are saturated, any additional zn would be available for metabolism.

\subsubsection{Phosphorus concentration and uptake in bean plants}

Application of $P$ in all soils resulted in significant increase of the mean $P$ concentration (Tables 4.2 .32 to 4.2.34) and uptake (Tables 4.2 .35 to 4.2 .37 ) in all plant parts of beans at both sampling times. The expression of this increase varied among soils and plant parts. Linear increases in $P$ concentration with $P$ application $r a t e s$ were obtained at maturity only in the roots of beans grown on the Sutherland and Meota soils and in the seed on the Carrot River and Sutherland soils (Tables 4.2 .32 to 4.2.34). P uptake was increased linearly with $P$ application rate in the roots of mature beans grown on the Sutherland and Meota soils and the straw on the Meota soil.

Application of $\mathrm{Zn}$ had a variable effect on $\mathrm{P}$ concentration and uptake of beans. Thus, $P$ concentration and uptake in above ground plant parts grown on the Sutherland and Carrot River soils decreased significantly with application of $\mathrm{zn}$ (Tables $4.2 .32,4.2 .33,4.2 .35$ 
Table 4.2.32 Effect of $P$ and $\mathrm{Zn}$ application on the $\mathrm{P}$ concentration of beans grown on Sutherland soil.

\begin{tabular}{|c|c|c|c|c|c|c|}
\hline \multicolumn{2}{|c|}{ Treatment } & \multicolumn{2}{|c|}{$1 / 10$ bloom stage } & \multicolumn{3}{|c|}{ Maturity } \\
\hline$P$ & $\mathrm{Zn}$ & Roots & Tops & Roots & Seeds & Straw \\
\hline \multicolumn{2}{|c|}{$\mathrm{mg} \mathrm{kg} \mathrm{g}^{-1}$} & & & \multicolumn{3}{|l|}{$\mathrm{g} \mathrm{kg}^{-1}$} \\
\hline \multirow[t]{3}{*}{0} & 0 & 1.09 & 1.68 & 1.37 & 4.21 & 0.96 \\
\hline & 5 & 1.11 & 1.75 & 1.40 & 4.17 & 0.98 \\
\hline & 10 & 1.30 & 1.80 & 1.41 & 4.13 & 0.95 \\
\hline \multirow[t]{3}{*}{40} & 0 & 1.78 & 3.29 & 1.63 & 5.54 & 2.28 \\
\hline & 5 & 1.83 & 2.11 & 1.83 & 3.70 & 1.50 \\
\hline & 10 & 2.01 & 2.40 & 1.84 & 3.49 & 1.56 \\
\hline \multirow[t]{3}{*}{80} & 0 & 1.89 & 6.20 & 2.14 & 5.76 & 3.19 \\
\hline & 5 & 2.06 & 3.41 & 2.49 & 3.78 & 2.16 \\
\hline & 10 & 2.05 & 3.04 & 2.48 & 3.90 & 2.20 \\
\hline 160 & 0 & 2.03 & 8.07 & 2.97 & 6.05 & 3.82 \\
\hline \multirow[t]{2}{*}{-} & 5 & 2.33 & 4.60 & 3.56 & 4.07 & 2.27 \\
\hline & 10 & 2.67 & 4.16 & 3.44 & 4.06 & 2.34 \\
\hline
\end{tabular}

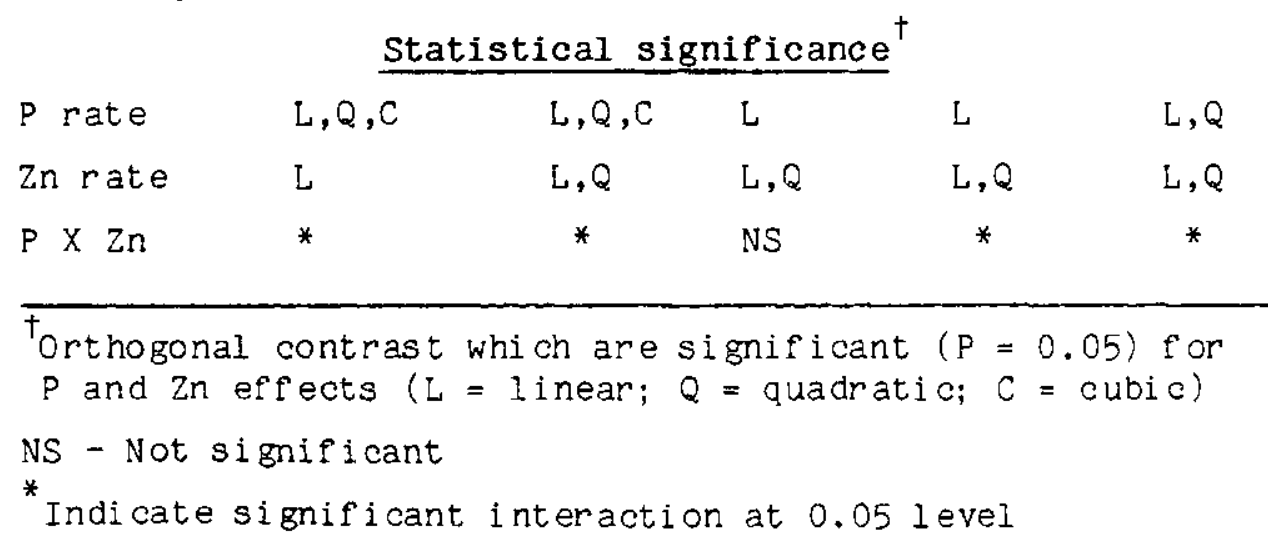


Table 4.2.33 Effect of $P$ and Zn application on the $P$ concentration of beans grown on Carrot River soil.

\begin{tabular}{|c|c|c|c|c|c|c|}
\hline \multicolumn{2}{|c|}{ Treatment } & \multicolumn{2}{|c|}{$1 / 10$ bloom stage } & \multicolumn{3}{|c|}{ Maturity } \\
\hline$P$ & $\mathrm{Zn}$ & Roots & Tops & Roots & Seeds & Straw \\
\hline \multicolumn{2}{|c|}{$\mathrm{mg} \mathrm{kg}^{-1}$} & & & \multicolumn{3}{|l|}{$\mathrm{g} \mathrm{kg}^{-1}$} \\
\hline \multirow[t]{2}{*}{0} & 0 & 1.84 & 2.34 & 1.94 & 4.05 & 2.10 \\
\hline & 5 & 2.02 & 1.93 & 2.12 & 3.71 & 2.02 \\
\hline \multirow[t]{2}{*}{40} & 0 & 2.31 & 4.50 & 3.27 & 5.11 & 3.34 \\
\hline & 5 & 2.63 & $3 \cdot 30$ & 3.67 & 3.42 & 1.98 \\
\hline \multirow[t]{2}{*}{80} & 0 & 2.72 & 6.23 & 4.82 & 6.26 & 3.88 \\
\hline & 5 & 3.01 & 4.02 & 5.54 & 3.56 & 2.57 \\
\hline \multirow[t]{2}{*}{160} & 0 & 4.68 & 8.27 & 5.75 & 6.90 & 4.32 \\
\hline & 5 & 5.58 & 5.15 & 6.05 & 3.78 & 3.06 \\
\hline
\end{tabular}

\section{Statistical significance $^{\dagger}$}

$\begin{array}{lccccc}\text { P rate } & L, Q, C & L, Q & L, Q, C & L & L, Q \\ \text { Zn rate } & * & * & * & * & * \\ P \times \text { Zn } & * & * & \text { NS } & * & *\end{array}$

Torthogonal contrast which are significant $(P=0.05)$ f or $P$ effects ( $L=1$ inear; $Q=$ quadratic; $C=$ cubi $C$ )

NS - Not significant

* Indicate $0.05 \mathrm{signif}$ icance level for $\mathrm{Zn}$ and interaction effects 
Table 4.2.34 Effect of $P$ and $Z n$ application on the $P$ concentration of beans grown on Meota soil.

\begin{tabular}{|c|c|c|c|c|c|c|}
\hline \multicolumn{2}{|c|}{ Treatment } & \multicolumn{2}{|c|}{$1 / 10$ bloom stage } & \multicolumn{3}{|c|}{ Maturity } \\
\hline$P$ & $\mathrm{Zn}$ & Roots & Tops & Roots & Seeds & Straw \\
\hline \multicolumn{2}{|c|}{$\mathrm{mg} \mathrm{kg}^{-1}$} & - & & \multicolumn{3}{|l|}{$\mathrm{g} \mathrm{kg}^{-1}$} \\
\hline \multirow[t]{2}{*}{0} & 0 & 1.40 & 1.97 & 1.86 & 2.85 & 1.47 \\
\hline & 5 & 1.64 & 1.86 & 1.95 & 2.73 & 1.23 \\
\hline \multirow[t]{2}{*}{40} & 0 & 2.83 & 3.96 & 2.34 & 4.19 & 1.39 \\
\hline & 5 & 3.51 & 3.71 & 2.42 & 3.91 & 1.24 \\
\hline \multirow[t]{2}{*}{80} & 0 & 3.95 & 4.93 & 3.16 & 5.03 & 2.04 \\
\hline & 5 & 4.01 & 4.31 & 3.28 & 4.76 & 1.86 \\
\hline \multirow[t]{2}{*}{160} & 0 & 4.88 & 5.35 & 4.69 & 5.47 & 3.15 \\
\hline & 5 & 4.41 & 4.88 & 4.83 & $5 \cdot 38$ & 3.10 \\
\hline
\end{tabular}

\section{$\underline{\text { Statistical significance }}^{\dagger}$}

$\begin{array}{cccccc}\text { P rate } & \text { L,Q } & \text { L, Q } & \text { L } & \text { L, Q } & \text { L, Q, C } \\ \text { Zn rate } & \text { NS } & * & \text { NS } & * & * \\ P \times \text { Zn } & \text { NS } & \text { NS } & \text { NS } & \text { NS } & \text { NS }\end{array}$

Torthogonal contrast which are significant $(P=0.05)$ for $P$ effects ( $L=1$ inear; $Q=$ quadratic; $C=$ cubi $C$ )

NS - Not significant

* Indicate 0.05 significance level for $\mathrm{Zn}$ ef fects 
Table 4.2.35 Effect of $P$ and $Z n$ application on the $P$ uptake of beans grown on Sutherland soil.

\begin{tabular}{|c|c|c|c|c|c|c|}
\hline \multicolumn{2}{|c|}{ Treatment } & \multicolumn{2}{|c|}{$1 / 10$ bloom stage } & \multicolumn{3}{|c|}{ Maturity } \\
\hline$P$ & $\mathrm{Zn}$ & Roots & Tops & Roots & Seeds & Straw \\
\hline \multicolumn{2}{|c|}{$\mathrm{mg} \mathrm{kg} \mathrm{kg}^{-1}$} & 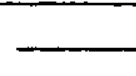 & 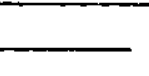 & \multicolumn{3}{|l|}{$\mathrm{mg} \operatorname{pot}^{-1}$} \\
\hline 0 & 0 & 0.33 & 2.20 & 0.72 & 6.56 & 1.96 \\
\hline & 5 & 0.35 & 2.11 & 0.73 & 5.90 & 2.02 \\
\hline & 10 & 0.39 & 1.87 & 0.66 & 5.62 & 1.92 \\
\hline \multirow[t]{3}{*}{40} & 0 & 1.07 & 7.14 & 1.59 & 22.98 & 9.05 \\
\hline & 5 & 1.15 & 6.16 & 1.92 & 20.08 & 7.51 \\
\hline & 10 & 1.24 & 6.59 & 1.74 & 18.95 & 8.07 \\
\hline \multirow[t]{3}{*}{80} & 0 & 1.09 & 11.52 & 2.35 & 24.40 & 12.95 \\
\hline & 5 & 1.33 & 10.88 & 2.36 & 20.19 & 11.45 \\
\hline & 10 & $1 \cdot 33$ & 10.28 & $2 \cdot 36$ & 21.56 & 11.63 \\
\hline \multirow[t]{3}{*}{160} & 0 & 1.11 & 15.53 & 3.06 & 24.06 & 15.20 \\
\hline & 5 & 1.27 & 14.33 & 3.82 & 23.20 & 12.63 \\
\hline & 10 & 1.67 & 13.15 & 3.65 & 21.54 & 11.52 \\
\hline
\end{tabular}

\section{Statistical significance $^{\dagger}$}

$\begin{array}{llllll}\text { P rate } & \text { L, Q } & \text { L,Q } & \text { L } & \text { L, Q , C } & \text { L, Q } \\ \text { Zn rate } & \text { L } & \text { L } & \text { NS } & \text { L } & \text { L } \\ \text { P X Zn } & \text { NS } & \text { NS } & \text { NS } & \text { NS } & *\end{array}$

\footnotetext{
Forthogonal contrast which are significant ( $P=0.05)$ for $P$ and $Z n$ effects ( $L=$ linear; $Q=$ quadratic; $C=$ cubic) NS - Not significant

* Indicate significant interaction at 0.051 evel
} 
Table 4.2.36 Effect of $P$ and $Z n$ application on the $P$ uptake of beans grown on Carrot River soil.

\begin{tabular}{|c|c|c|c|c|c|c|}
\hline \multicolumn{2}{|c|}{ Treatment } & \multicolumn{2}{|c|}{$1 / 10$ bloom stage } & \multicolumn{3}{|c|}{ Maturity } \\
\hline$P$ & $\mathrm{Zn}$ & Roots & Tops & Roots & Seeds & Straw \\
\hline \multicolumn{2}{|c|}{$\mathrm{mg} \mathrm{kg}^{-1}$} & \multicolumn{5}{|c|}{$\mathrm{mg} \mathrm{pot}^{-1}$} \\
\hline 0 & 0 & 0.55 & 3.82 & 1.65 & 7.21 & 6.20 \\
\hline & 5 & 1.11 & 3.75 & 1.89 & 6.74 & 6.38 \\
\hline \multirow[t]{2}{*}{40} & 0 & 1.73 & 11.20 & 3.92 & 22.64 & 14.71 \\
\hline & 5 & 1.76 & 10.20 & 4.22 & 19.34 & 10.41 \\
\hline \multirow[t]{2}{*}{80} & 0 & 1.91 & 14.58 & 6.05 & 25.48 & 15.96 \\
\hline & 5 & 2.03 & 12.80 & 6.94 & 22.38 & 13.98 \\
\hline \multirow[t]{2}{*}{160} & 0 & 3.16 & 19.04 & 6.76 & 27.28 & 18.97 \\
\hline & 5 & 4.17 & 18.08 & 7.57 & 22.90 & 17.49 \\
\hline
\end{tabular}

\section{Statistical significance $^{\dagger}$}

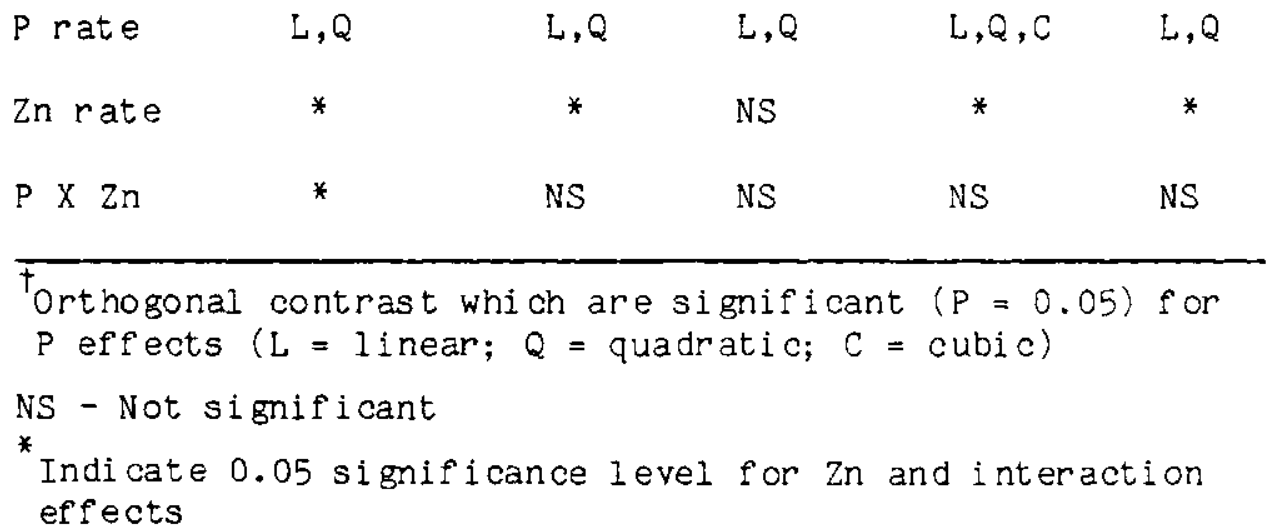


Table 4.2.37 Effect of $P$ and $Z n$ application on the $P$ uptake of beans grown on Meota soil.

\begin{tabular}{|c|c|c|c|c|c|c|}
\hline \multicolumn{2}{|c|}{ Treatment } & \multicolumn{2}{|c|}{$1 / 10$ bloom stage } & \multicolumn{3}{|c|}{ Maturity } \\
\hline $\mathrm{P}$ & $\mathrm{Zn}$ & Roots & Tops & Roots & Seeds & Straw \\
\hline \multicolumn{2}{|c|}{$\mathrm{mg} \mathrm{kg}{ }^{-1}$} & \multicolumn{5}{|c|}{$m g$ pot $^{-1}$} \\
\hline 0 & 0 & 0.70 & 4.75 & 2.93 & 16.72 & 8.14 \\
\hline & 5 & 0.70 & 4.09 & 3.06 & 16.21 & 7.05 \\
\hline \multirow[t]{2}{*}{40} & 0 & 1.98 & 11.58 & 4.62 & 34.24 & 9.53 \\
\hline & 5 & 2.45 & 11.39 & 4.85 & 31.26 & 8.71 \\
\hline \multirow[t]{2}{*}{80} & 0 & 2.76 & 14.11 & 6.20 & 41.20 & 14.89 \\
\hline & 5 & 2.91 & 13.38 & 6.65 & 40.27 & 14.42 \\
\hline \multirow[t]{2}{*}{160} & 0 & 3.28 & 17.49 & 8.95 & 43.78 & 22.97 \\
\hline & 5 & 3.68 & 15.64 & 9.51 & 42.89 & 22.88 \\
\hline
\end{tabular}

Statistical significance $^{\dagger}$

$\begin{array}{llllll}P \text { rate } & \mathrm{L}, \mathrm{Q} & \mathrm{L}, \mathrm{Q}, \mathrm{C} & \mathrm{L} & \mathrm{L}, \mathrm{Q} & \mathrm{L}\end{array}$

$\begin{array}{lllll}\text { Zn rate } & \text { NS } & \text { NS } & \text { NS } & \text { NS }\end{array}$

$\begin{array}{llllll}\mathrm{P} \times \mathrm{Zn} & \mathrm{NS} & \mathrm{NS} & \mathrm{NS} & \mathrm{NS} & \mathrm{NS}\end{array}$

Trthogonal contrast which are significant $(P=0.05)$ for

$P$ effects ( $L=I$ inear; $Q=$ quadrati $c ; C=c u b i c$ )

NS - Not significant 
and 4.2.36). In the Meota soil, only the concentration of $P$ in above ground parts was significantly decreased by $z$ n application (Table 4.2.34), whereas $P$ uptake remained unaffected (Table 4.2.37). Application of $2 n$ to the Sutherland and Carrot River soils caused an increase in root $P$ at both growth stages but $P$ uptake was increased only at $1 / 10$ bloom stage (Tables $4.2 .32,4.2 .33,4.2 .35$ and 4.2 .36 ) A significant $P X Z n$ interaction on $P$ concentration in root at $1 / 10$ bloom stage and $\mathrm{P}$ concentration in above ground plant parts at both stages was obtained both in Sutherland and Carrot River soils (Tables 4.2.32 and 4.2.33). When no $\mathrm{Zn}$ was applied, $\mathrm{P}$ concentration in the tops of bean at $1 / 10$ bloom stage increased from 3.29 at $40 \mathrm{mg} \mathrm{p} \mathrm{kg}-1$ to $8.07 \mathrm{~g} \mathrm{~kg}^{-1}$ at $160 \mathrm{mg} \mathrm{P} \mathrm{kg}^{-1}$ in the Sutherland soil (Table 4.2.32) and from 4.5 to to $8.27 \mathrm{~g} \mathrm{~kg}^{-1}$ in the corresponding treatment in the Carrot River soil ( $T a b l e$ 4.2.33). In contrast, relatively small increases in $P$ concentration $\left(3.96\right.$ to $5.35 \mathrm{~g} \mathrm{~kg}^{-1}$ ) were observed in the Meota soil as a result of raising $P$ levels from $40 \mathrm{mg} \mathrm{P} \mathrm{kg}^{-1}$ to $160 \mathrm{mg} \mathrm{P} \mathrm{kg}^{-1}$ (Table 4.2.34). Application of $\mathrm{Zn}$ caused a significant decrease in $P$ concentration in the above ground plant parts. This decrease was greater at 80 or $160 \mathrm{mg}^{2}$ aplied $\mathrm{P} \mathrm{kg}^{-1}$ of soil than at 40 $\mathrm{mg}$ applied $\mathrm{P} \mathrm{kg} \mathrm{g}^{-1}$ of soil. In contrast to the $\mathrm{P}$ concentration in above ground plant parts, root $\mathrm{P}$ concentration increased significantly with the application of $2 n$ in the presence of $P$ than in its absence. Thus applied $\mathrm{Zn}$ reduced concentration of $\mathrm{P}$ in the above ground parts at high rates of applied $P$ but increased it in the roots. This decrease in concentration of $\mathrm{P}$ in the above ground plant parts can be attributed to a positive $P X \mathrm{Zn}$ interaction on the yield of beans as no significant $P X \mathrm{Zn}$ interaction was observed on the $\mathrm{P}$ uptake of the 
above ground plant parts. Although statistical analysis indicated no significant effect of $Z n$ on $P$ uptake, there was a declining trend in $P$ uptake with the application of $\mathrm{Zn}$ at all levels of applied $P$.

These results support the recent findings of Loneragan et al. (1982) that $\mathrm{Zn}$ deficiency may enhance $\mathrm{P}$ absorption and transport to such an extent that it may accumulate to higher levels in tops. However, these results do not agree with the hypothesis of Loneragan et al. (1982) that $P$ toxicity may be a problem under conditions of low $\mathrm{Zn}$ and high $\mathrm{P}$ supply, for two reasons. First, the concentration of $P$ in the tops of bean in this experiment were below the toxic I evel (Ozanne, 1980). Secondly, the PX Zn interaction was observed at all rates of $P$ application. Moreover, high levels of $P$ in this experiment decreased the concentration of $\mathrm{zn}$ in the tops of bean to near critical levels (Tables 4.2 .26 and 4.2 .27 ) and the magnitude of reduction in $\mathrm{Zn}$ concentration was greatest at the $40 \mathrm{mg}^{\mathrm{P} \mathrm{kg}^{-1}}$ rate. Only a small additional drop due to 80 or $160 \mathrm{mg} \mathrm{P} \mathrm{kg}^{-1}$ rate was observed.

\subsubsection{Zinc and $P$ derived from applied source}

Doubling the amount of $Z$ n fertilizer resulted in a significant increase in $\mathrm{Zn}$ derived from fertilizer (\% Zndf) by roots and above ground parts of beans in the sutherland soil at both growth stages (Table 4.2.38). The increase in $\%$ Zndff from the $5 \mathrm{mg} \mathrm{zn} \mathrm{kg}^{-1}$ to the $10 \mathrm{mg} \mathrm{Zn} \mathrm{kg} \mathrm{kg}^{-1}$ treatment, indicates a preferential uptake of the more readily available form of $2 n$ fertilizer. The $\%$ Zndf $f$ by bean roots decreased significantly with $P$ application in all soils but the effect was more pronounced in the Meota soil (Tables 4.2.38 to 4.2.40). In contrast to $\%$ Zndff in roots, the $\%$ Zndf in tops, seeds and straw in 
Table 4.2.38 Zinc derived from fertilizer ( $\%$ Indff) by beans grown on Sutherland soil.

\begin{tabular}{|c|c|c|c|c|c|c|}
\hline \multicolumn{2}{|c|}{ Treatment } & \multicolumn{2}{|c|}{$1 / 10$ bloom stage } & \multicolumn{3}{|c|}{ Maturity } \\
\hline$P$ & $\mathrm{Zn}$ & Roots & Tops & Roots & Seeds & Straw \\
\hline \multicolumn{2}{|c|}{$\mathrm{mg} \mathrm{kg}^{-1}$} & - & . & $\%$ Zndff & & \\
\hline 0 & 5 & 27.0 & 42.0 & 37.7 & 41.0 & 40.7 \\
\hline 40 & 5 & 28.8 & 45.3 & 33.6 & 46.4 & 43.0 \\
\hline 80 & 5 & 24.5 & 51.2 & 32.2 & 52.9 & 53.3 \\
\hline 160 & 5 & 22.7 & 52.2 & 34.4 & 55.4 & 54.7 \\
\hline 0 & 10 & 49.2 & 54.3 & 41.6 & 42.0 & 43.4 \\
\hline 40 & 10 & 38.5 & 58.4 & 39.9 & 57.9 & 59.2 \\
\hline 80 & 10 & 38.4 & 60.9 & $37 \cdot 3$ & 62.3 & 64.4 \\
\hline 160 & 10 & 37.8 & 60.3 & 35.8 & 63.4 & 62.9 \\
\hline
\end{tabular}

Statistical significance $^{\dagger}$

$\begin{array}{llllcc}P \text { rate } & \text { L } & \text { L } & \text { NS } & \text { L, Q } & \text { L, Q } \\ \text { Zn rate } & * & * & * & * & * \\ P X \text { Zn } & \text { NS } & \text { NS } & \text { NS } & \text { NS } & \text { NS }\end{array}$

Torthogonal contrast which are significant $(P=0.05)$ for $P$ effects $(L=$ Iinear; $Q=$ quadratic)

NS - Not significant

* Indicate significant effect of $2 n$ at 0.05 level 
Table 4.2.39 Zinc derived from fertilizer (\% Zndff) by beans grown on Carrot River soil.

\begin{tabular}{|c|c|c|c|c|c|c|}
\hline \multicolumn{2}{|c|}{ Treatment } & \multicolumn{2}{|c|}{$1 / 10$ bloom stage } & \multicolumn{3}{|c|}{ Maturity } \\
\hline$P$ & $2 n$ & Roots & Tops & Roots & Seeds & Straw \\
\hline \multicolumn{2}{|c|}{$\mathrm{mg} \mathrm{kg}^{-1}$} & & & \# Zndff & & $5=$ \\
\hline 0 & 5 & 51.7 & 41.9 & 51.7 & 49.1 & 52.8 \\
\hline 40 & 5 & 53.6 & 46.5 & 51.5 & 52.5 & 54.0 \\
\hline 80 & 5 & 49.6 & 48.1 & 48.1 & 58.7 & 54.5 \\
\hline 160 & 5 & 47.8 & 49.0 & 47.7 & 59.5 & 55.2 \\
\hline
\end{tabular}

\section{Statistical significance $^{\dagger}$}

$\begin{array}{lllll}P \text { rate } & L & \mathrm{~L} & \mathrm{~N} & \mathrm{~N}\end{array}$

Orthogonal contrast which are significant $(P=0.05)$. for $P$ effects ( $L=1$ inear)

NS - Not significant

Table 4.2.40 Zine derived from fertilizer (\% Zndff) by beans grown on Meota soil.

\begin{tabular}{|c|c|c|c|c|c|c|}
\hline \multicolumn{2}{|c|}{ Treatment } & \multicolumn{2}{|c|}{$1 / 10$ bl oom stage } & \multicolumn{3}{|c|}{ Maturity } \\
\hline$P$ & $2 n$ & Roots & Tops & Roots & Seeds & Straw \\
\hline \multicolumn{2}{|c|}{$\mathrm{mg} \mathrm{kg}^{-1}$} & & 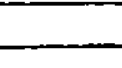 & $\%$ & & \\
\hline 0 & 5 & 44.6 & 29.4 & 17.0 & 24.1 & 26.9 \\
\hline 40 & 5 & 23.5 & 24.1 & 8.9 & 24.7 & 24.0 \\
\hline 80 & 5 & 21.8 & 24.0 & 7.9 & 24.9 & 22.0 \\
\hline 160 & 5 & 18.4 & 21.4 & 8.4 & 24.4 & 23.9 \\
\hline
\end{tabular}

Statistical significance $^{\dagger}$

$\begin{array}{llllll}\text { P rate } & L, Q, C & \mathrm{C} & \mathrm{L}, \mathrm{Q} & \mathrm{NS} & \mathrm{NS}\end{array}$
Torthogonal contrast which are significant $(P=0.05)$ for
$P$ effects $(L=$ Iinear; $Q=$ quadratic $)$

NS - Not significant 
the Sutherland soil and tops and seeds in the Carrot River soil increased significantly with $P$ application (Tables 4.2 .38 and 4.2.39). In the Meota soil, however, it decreased significantly with $P$ application at $1 / 10$ bloom stage and remained unafected at maturity (Table 4.2 .40$)$

The \% Zndf $f$ was affected by soil properties and native labile pool of $\mathrm{Zn}$. Depending on $\mathrm{P}$ level, plant part, and growth stage, $22.7 \%$ to $55.4 \%, 41.9 \%$ to $59.6 \%$ and 7.9 to $44.6 \%$ of $\mathrm{Zn}$ was derived from applied sources ( $5 \mathrm{mg} \mathrm{Zn} \mathrm{kg}^{-1}$ ) by beans grown on Sutherland, Carrot River, and Meota soils, respectively (Tables 4.2 .38 and 4.2.40). The higher values obtained in Carrot River and Sutherland soils compared to the Meota soil may well be related to their DTPA-extractable soil Zn levels. The DTPA-extractable $\mathrm{Zn}$ levels in three soils foliowed the sequence: Meota > Sutherland > Carrot River (Table 3.2, Section $3.2 \cdot 3)$.

The $P$ derived from fertilizer ( $\%$ Pdff) in roots at $1 / 10$ bloom stage increased significantly with $Z$ n application in all three soils (Table 4.2.41). However, it was decreased with Zn application only in tops of beans grown on the Carrot River soil (Table 4.2.41). Yadav and Shukla (1982) have published autoradiographs that show more $P$ retention in the roots when $P$ and $Z n$ were applied together compared to P application alone.

Phosphorus application increased Pdff in both roots and tops of beans in all soils (Table 4.2.41). Similar increase in pdf with increasing amounts of $P$ fertilizer has been reported by $N$ ychas and Skarlou (1983). The $\%$ Pdff was also a function of soil properties. In the sutherland soil, $56 \%$ to $90.6 \%$ and $59.6 \%$ to $80 \%$ of the $P$ was 
Table 4.2.41 Phosphorus derived from fertilizer (\% Pdff) of beans at $1 / 10$ bloom stage in three soils.

\begin{tabular}{|c|c|c|c|c|c|c|c|}
\hline \multicolumn{2}{|c|}{ Treatment } & \multicolumn{2}{|c|}{ Sutherland } & \multicolumn{2}{|c|}{ Carrot River } & \multicolumn{2}{|c|}{ Meota } \\
\hline$P$ & $2 n$ & Root & Top & Root & TOP & Root & TOP \\
\hline \multicolumn{2}{|c|}{$m g \mathrm{~kg}^{-1}$} & & & \multicolumn{2}{|c|}{$\%$ Pdff } & & \\
\hline \multirow[t]{3}{*}{40} & 0 & 56.0 & 59.6 & 41.6 & 46.8 & 38.4 & 47.6 \\
\hline & 5 & 58.2 & 59.2 & 43.0 & 44.9 & 40.0 & 44.7 \\
\hline & 10 & 58.9 & 57.6 & - & -- & -- & -- \\
\hline \multirow[t]{3}{*}{80} & 0 & 69.7 & 69.3 & 63.8 & 53.8 & 56.5 & 56.1 \\
\hline & 5 & 72.2 & 67.0 & 65.0 & 50.5 & 57.4 & 54.4 \\
\hline & 10 & 75.9 & 67.8 & - & -- & -- & - \\
\hline \multirow[t]{3}{*}{160} & 0 & 88.2 & 82.0 & 77.2 & 72.0 & 71.0 & 76.3 \\
\hline & 5 & 90.6 & 80.0 & 82.0 & 70.4 & 76.3 & 74.5 \\
\hline & 10 & 92.8 & 80.9 & -- & -- & - & -- \\
\hline
\end{tabular}

$\underline{\text { Statistical significance }}^{\dagger}$

\begin{tabular}{|c|c|c|c|c|c|c|}
\hline P rate & $L, Q$ & L & $L, Q$ & L & $L, Q$ & $\mathrm{~L}$ \\
\hline Zn rate & $\mathrm{L}$ & NS & * & * & * & NS \\
\hline$P \times \mathrm{Zn}$ & NS & NS & NS & NS & NS & NS \\
\hline \multicolumn{7}{|c|}{$\begin{array}{l}\text { †orthogonal contrast which are significant }(P=0.05) \text { for } \\
P \text { and } \mathrm{Zn} \text { effects }(L=1 \text { inear; } Q=\text { quadrati } C) \\
\text { NS - Not significant } \\
{ }^{*} \text { Indicate significant ef ect of } \mathrm{Zn} \text { at } 0.05 \text { level in Carrot }\end{array}$} \\
\hline
\end{tabular}


derived from applied $P$ in roots and tops, respectively. On the other hand, the $\%$ pdff in roots and tops of the corresponding treatments in the Carrot River or the Meota soil was relatively less (Table 4.2.41). This may be attributed to lower levels of bicarbonate-extractable soil $P$ in the sutherland soil.

\subsubsection{Effectiveness of Zn fertilizers}

The data for dry matter yield (DMY), $\mathrm{Zn}$ concentration and uptake from Experiment 1 are provided in Table 4.2.42. There was a significant effect of $\mathrm{Zn}$ application on the production of above ground plant material (DMY) for all sources used but there was no effect on roots (Table 4.2.42). The $Z n$ levels in the bean tissue of the control treatments (Table 4.2.42) were below the "desirable minimum zn concentration", which is required to achieve good yields and rapid maturation of beans (Boawn, 1973).

Zinc concentration and uptake in tops and roots increased significantly over the control treatments with applied $\mathrm{Zn}$ (Table 4.2.42). It was interesting to note that the highest $\mathrm{Zn}$ concentration and uptake in roots and tops was achieved with low-yield ammonium based 1 ignosul phonate $(\mathrm{ZnLY})$ and zinc sulphate $\left(\mathrm{ZnSO}_{4}\right)$. The higher values obtained for ZnLY, when compared to those with high-yield sodium based I ignosul phonate (ZnHY), are presumably a consequence of the lower lignin content (and, therefore, chelating ability) of this substrate (see Table 3.3, Section 3.2.4). This view is also supported by the relatively 1 ow DTPA-extractable $\mathrm{Zn}$ levels recovered in the ZnHY treatment in Experiment 1 (Table 4.2.42) and incubation experiment (Table 4.2.44). Of particular significance, however, is the 


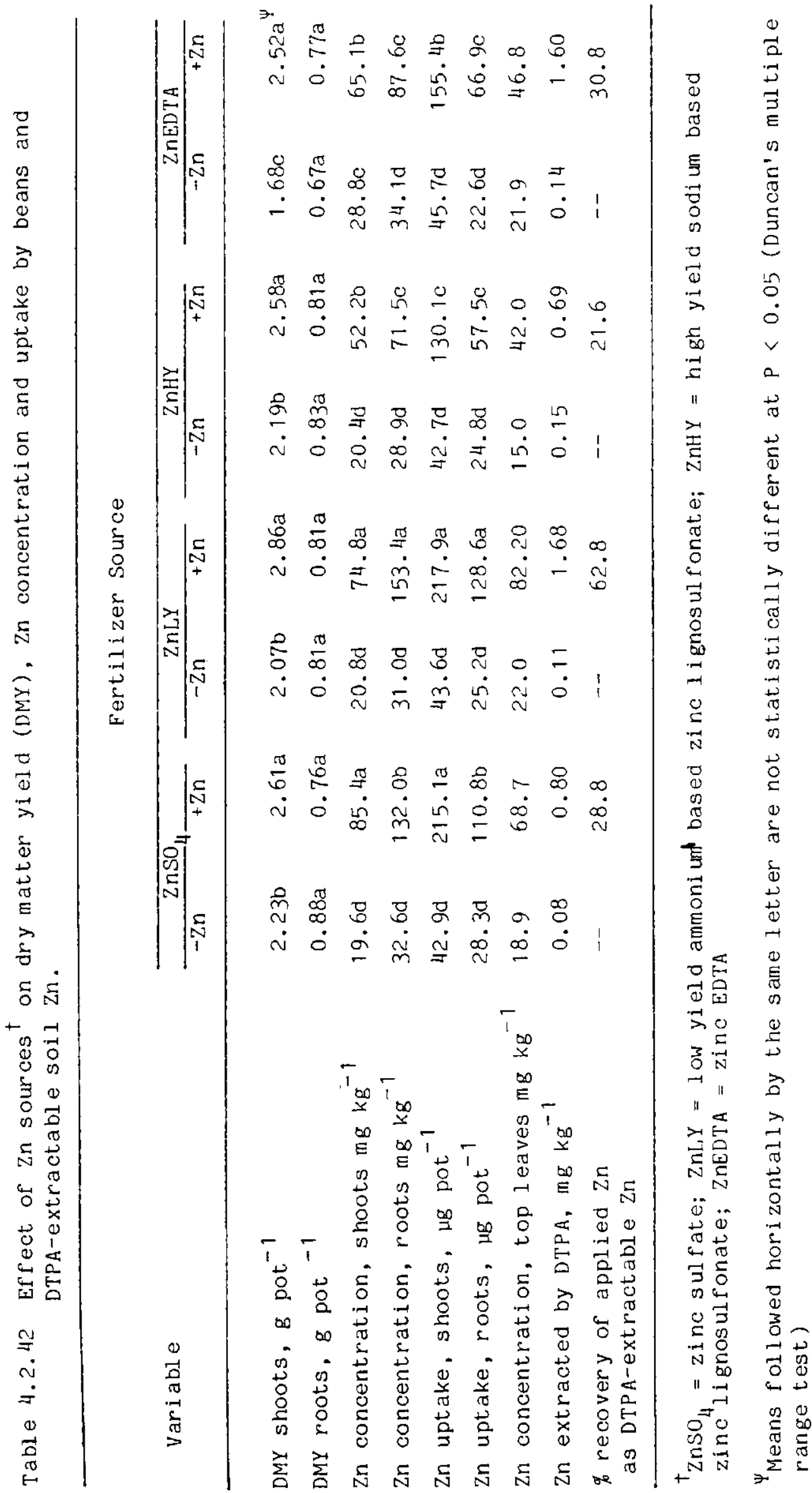


recognition that zinc EDTA (ZnEDTA), the most comonly used Zn chelating agent in field studies, was less effective than ZnLY in this experiment .

The second experiment was conducted to investigate the relative efficiencies of $\mathrm{ZnSO}_{4}$ and $\mathrm{ZnLY}$ at four $\mathrm{Zn}$ rates $(0,0.5,2.5$ and 5.0 mg $\mathrm{kg}^{-1}$ soil, respectively). Maximum yields were statistically obtained at different rates of appiied $\mathrm{Zn}$ for the two sources (Table 4.2.43). Maximum yield with ZnLY was obtained with appiscation of 2.5 $\mathrm{mg} \mathrm{Zn} \mathrm{kg}{ }^{-1}$ of soil compared to $0.5 \mathrm{mg} \mathrm{Zn} \mathrm{kg}^{-1}$ applied as $\mathrm{ZnSO}_{4}$. Dry matter yield obtained with $\mathrm{Zn}$ rates above these two levels with the corresponding sources was not significantly different. In contrast to yields, Zn concentration was significantly higher with ZnLY at 2.5 and $5 \mathrm{mg} \mathrm{Zn} \mathrm{kg}{ }^{-1}$ treatments compared to the same treatments of $\mathrm{ZnSO}_{4}$. Chelating agents are known to enhance the uptake of $Z n$ by increasing the rate of diffusion in the immediate vicinity of plant roots (Elgawhary et al., 1970; halvorson and Lindsay, 1977).

The amount of $\mathrm{Zn}$ extracted by DTPA after incubation varied with each $\mathrm{Zn}$-source and soil (Table 4.2.44). At the end of the incubation period ( 5 weeks at $25 \pm 1^{\circ} \mathrm{C}$ ), DTPA-extractable $\mathrm{Zn}$ ranged from 34.6 to 63.5\% for the $\mathrm{ZnSO}_{4}$ treatment, 49.5 to $70.3 \%$ for the ZnEDTA treatment, 90.1 to $94.4 \%$ for the ZnLY treatment, and 28.9 to $49.2 \%$ for the ZnHY treatment.

One significant feature of these results is that when $2 n$ was applied as ZnEDTA, lower recoveries ( 49.5 to $57.5 \%$ ) were obtained from soils with high organic matter and clay content and high calcium concentration (Table 3.4, section 3.2.4). The mobility and fixation of $\mathrm{Zn}$ applied as ZnEDTA has been shown to be related to the Ca 


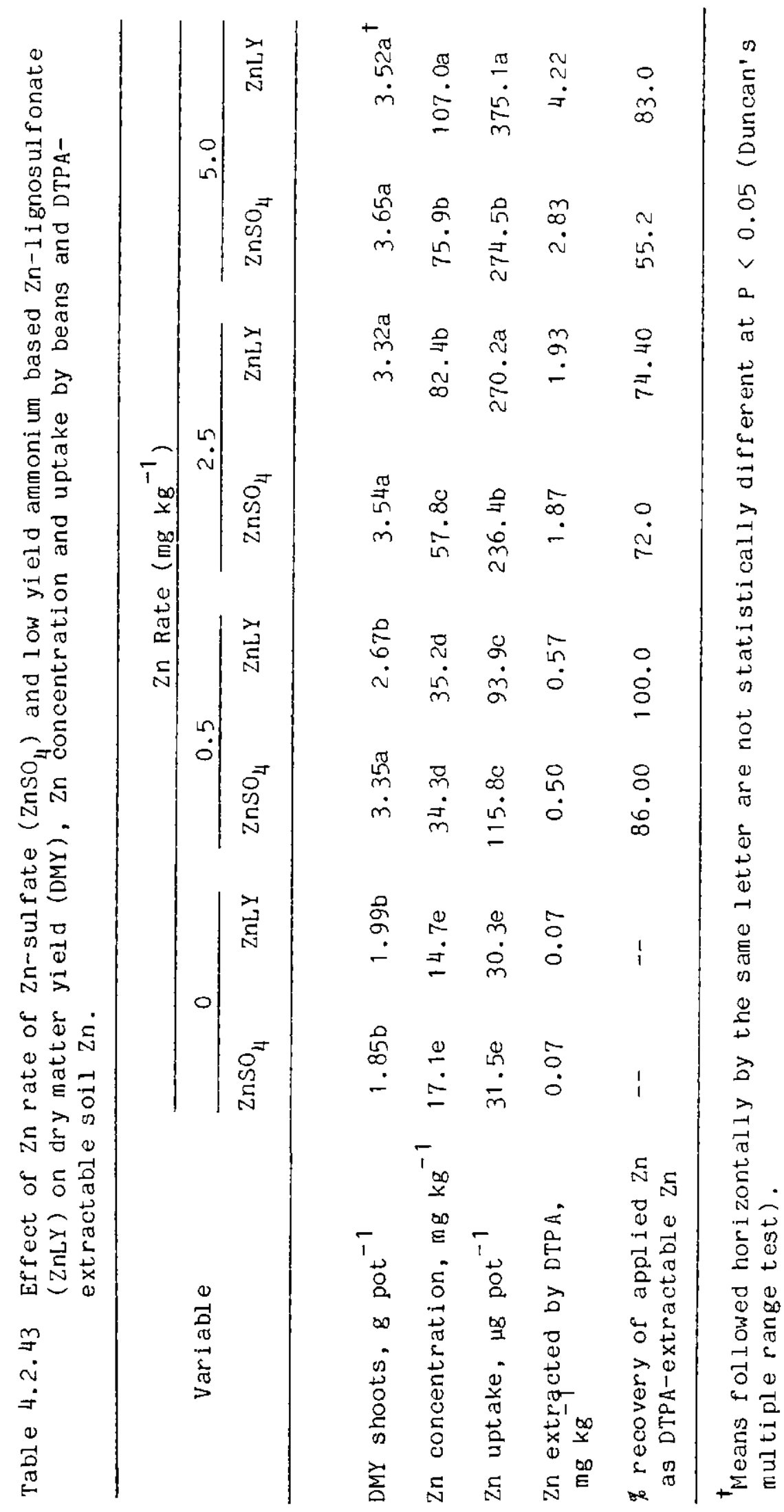


Table 4.2.44 Recovery of applied $\mathrm{zn}$ by DTPA in the incubation experiment.

\begin{tabular}{|c|c|c|c|c|}
\hline \multirow{2}{*}{ Soil } & \multicolumn{4}{|c|}{$\begin{array}{c}\text { \% recovery of applied } \mathrm{zn} \\
\text { by DTPA }\end{array}$} \\
\hline & $\mathrm{ZnSO}_{4}$ & $\operatorname{ZnLY}$ & $\mathrm{ZnHY}$ & ZnEDTA \\
\hline Regosolic very fine sandy loam & 34.6 & 90.1 & 28.9 & 70.3 \\
\hline Chernozemic loamy very fine sand & 39.1 & 90.2 & 34.9 & 57.7 \\
\hline Chernozemic I oam & 50.5 & 93.0 & 42.7 & 55.9 \\
\hline Chernozemic silty loam & 63.5 & 94.1 & 42.2 & 49.5 \\
\hline
\end{tabular}

concentration, carbonate content and soil type (Hochberg and Lahav, 1978).

\subsection{Distribution of Native and Applied Zinc}

\subsubsection{Distribution of native $\mathrm{Zn}$}

Amounts and percent distribution of native $\mathrm{Zn}$ among the water soluble plus exchangeable (nonspecifically adsorbed (EX)), exchangeable (specifically adsorbed (ExAD)), organic (OM), manganese oxide $(M n O X), F e$ oxide $(F e X)$ and residual (RES) fractions of the soils studied is summarized in Table 4.3.1. The sum of all $\mathrm{Zn}$ fractions rarely differed by more than $5 \%$ of the total $\mathrm{Zn}$ analysis.

The amounts and the percent distribution of total $\mathrm{zn}$ in different fractions varied widely in three soils. The percentage of $\mathrm{Zn}$ in EX, EXAD, OM and MnoX fractions averaged $0.2,0.7,7$ and $1.4 \%$, respectively (Table 4.3.1). All three soils contained very low amounts of exchangeable (nonspecifically or specifically adsorbed) and 


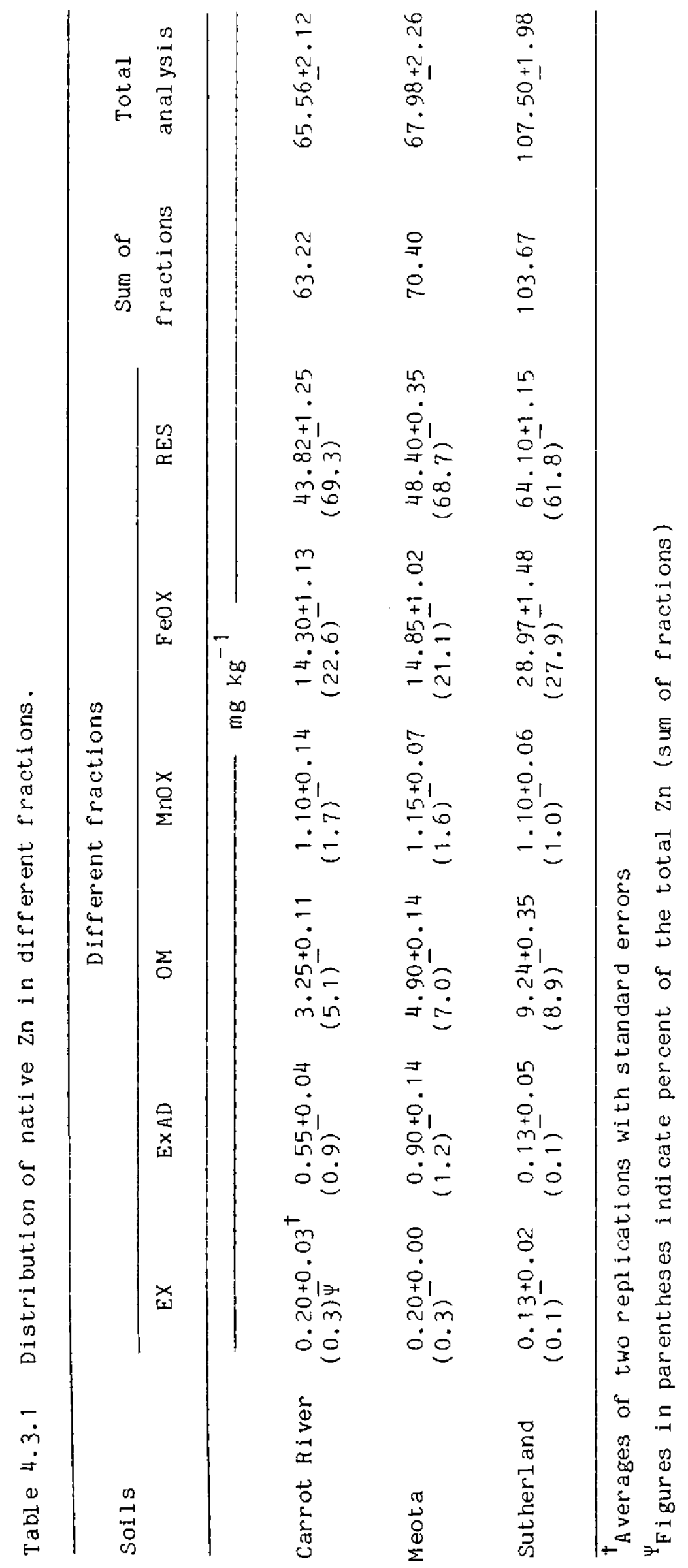


Mnox native $\mathrm{Zn}$. Relatively low amounts of exchangeable $\mathrm{Zn}$ have also been reported by other workers (Sedberry and Reddy, 1976; Shuman, 1979; I yengar et a1., 1981). Most of the $\mathrm{Zn}$ was associated with organic matter, Fe oxides and the residual mineral fractions. The OM fraction was significantly lower in the Carrot River soil compared to the Meota soil, which in turn was less than that of the Sutherland soil. This is in agreement with studies relating $2 n$ in this fraction to soil organic matter levels (Iyengar et al., 1981).

The RES and FeoX fractions in the three soils averaged $66.6 \%$ and $23.9 \%$, respectively, and constituted the major proportion of the native soil Zn. Fractionation of $\mathrm{Zn}$ in several Georgia (Shuman, 1979) and Virginia (Iyengar et al., 1981) soils has shown that up to $70 \%$ and 25\% of the total $\mathrm{Zn}$ was associated with residual and $\mathrm{Fe}$ oxide fractions, respectively. Among the three soils in this study, the Sutherland soil had greater amounts of $\mathrm{Zn}$ in RES fraction compared to the Carrot River and Meota soils. Shuman (1979) has reported that a large portion of the total $\mathrm{Zn}$ is associated with clay-size fractions and considerably less with sand or silt fractions. However, the relatively high amounts of RES $2 n$ present in the sandy soils (Carrot River and Meota soils) of this study indicate that a significant portion of the RES $\mathrm{Zn}$ could be associated with sand-size particles. The Sutherland soil was high in free iron content, therefore $\mathrm{zn}$ associated with FeoX fraction was clearly high in this soil compared with the Carrot River and Meota soils.

\subsubsection{Distribution of applied $\mathrm{Zn}$}

The distribution of applied $Z n$ in various fractions of the 
three scils after seven days incubation is shown in Table 4.3.2. The amount and percent distribution of applied $2 n$ in $O M$, EeOX and MnOX fractions in all soils varied directly with organic carbon, Fe- and Mn-oxide contents. The greater proportion of $\mathrm{Zn}$ applied to the Carrot River soil was found to accumulate in ExAD (34.3\%) and EeoX (25.2\%) fractions (Table 4.3.2). In addition to $\operatorname{ExAD}(30.8 \%)$ and $\mathrm{F}$ eOX $(26.1 \%)$ fractions, significant amounts of applied $Z n$ to the Meota soil were recovered in the OM fraction (26.9\%) (Table 4.3.2). In the sutherland soil, however, most of the applied $\mathrm{Zn}$ was recovered in the OM (41.2\%) and $\mathrm{FeOX}(35 \%)$ fractions (Table 4.3.2). In contrast to the carrot River and Meota soils, the Sutherland soil had very low percentage of $\mathrm{Zn}$ in EX or EXAD fractions (Table 4.3.2). The percent recovery of $\mathrm{Zn}$ in Mnox fraction was $13.1,11.8$ and $16 \%$ in the Carrot River, Meota and Sutherland soils, respectively (Table 4.3.2).

Little $\mathrm{Zn}$ was found to be associated with the EX fraction in the Sutherland and Meota soils compared to the Carrot River soil (Table 4.3.2). This may be due to the much 1 ower pH of the latter soil. Shuman (1975) reported increases in $\mathrm{Zn}$ sorption with increasing soil pH, particularly on coarser textured soils. Similar decreases in exchangeable $\mathrm{Zn}$ with an increase in $\mathrm{pH}$ were observed to be associated with shifts of $2 n$ into organically complexed or oxides-bound fractions (Sims and Patrick, 1978; I yengar et al., 1981; Sims, 1986). There was no consistent effect of $\mathrm{pH}$ on the EXAD fraction in this study.

Shuman (1979) has reported that high amounts of exchangeabie $\mathrm{zn}$ in soils are associated with high cation exchange capacity. This conclusion was not verified by the results of this study, since the soil with the highest cation exchange capacity (Sutherland) contained 


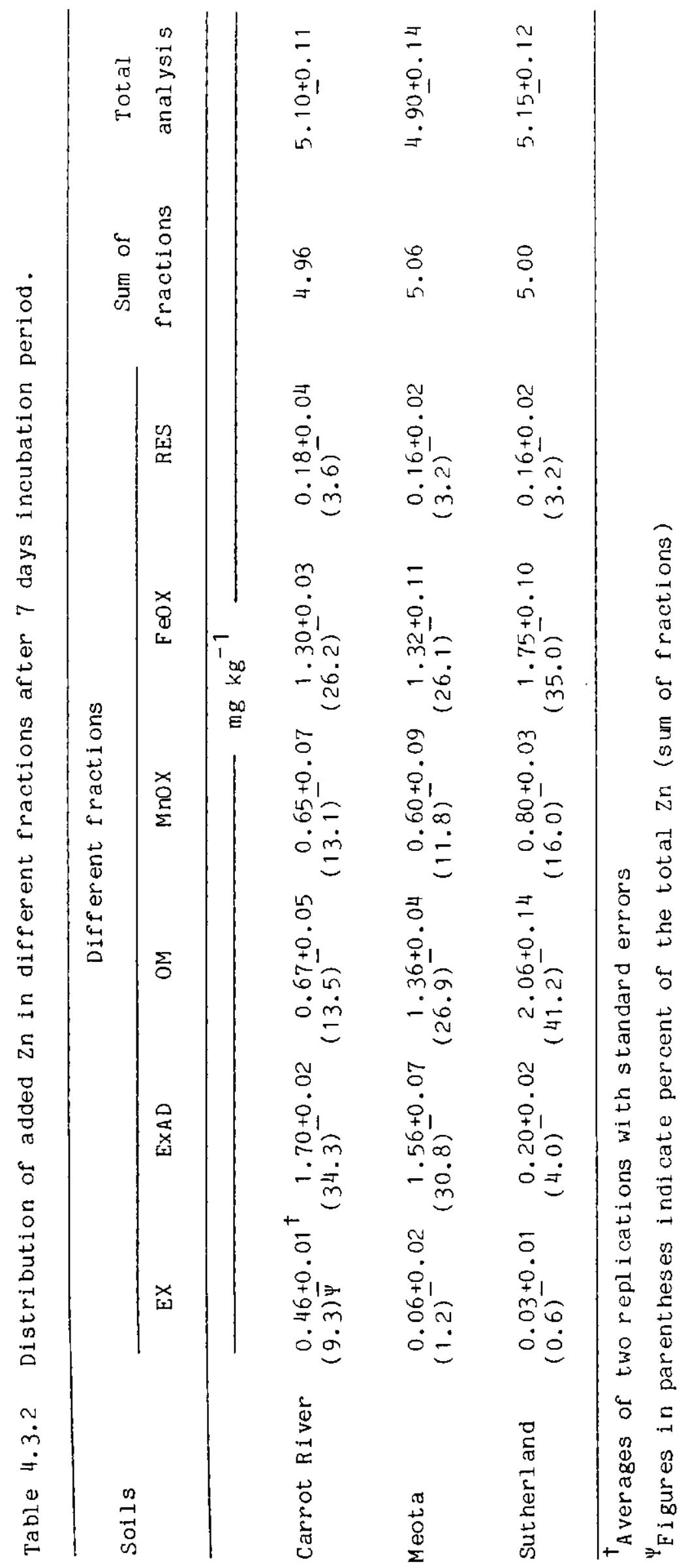


the least amount of exchangeable $\mathrm{Zn}$ (Table 4.3.2).

In spite of the low contents of free iron and manganese in the soils of this study (Table 3.2), oxides themselves appeared to have a marked effect on the distribution of applied $\mathrm{Zn}$, since a major portion of the added $\mathrm{Zn}$ was found in FeoX fraction. It has been shown that Al-, Feand Mn-oxides adsorb considerable quantities of $\mathrm{Zn}$ (Kinniburgh et al., 1976; Loganathan et al., 1977; Shuman, 1977) and that the adsorbed $\mathrm{zn}$ is Iargely non-exchangeable (Kalbasi et al., 1978). Cavallaro and McBride (1984) found that destruction of organic matter increased $\mathrm{Zn}$ sorption and concluded that the oxide component of the soil was more significant that the organic component in $\mathrm{Zn}$ sorption and fixation. Therefore, it seems likely that $\mathrm{Zn}$ is preferentially bonded to oxide fractions (Cavallaro and McBride, 1984).

One salient feature of the results of this study is that, in contrast to the distribution of native $\mathrm{Zn}$ (Table 4.3.1), only very small amounts of applied $\mathrm{Zn}(3.2$ to $3.6 \%)$ were recovered with RES fraction (Table 4.3.2). Keef er and Estepp (1971) found much higher amounts ( 30.7 to $58.2 \%$ ) of applied $Z n$ in the residual mineral fraction (clay-fixed nonexchangeable) of West Virginia soils compared with soils of this study. A portion of the clay-fixed $Z$ n in their study probably was associated with Al-, Fe- and Mn-oxides and hydroxides, since the fractionation technique used by the authors did not account for these fractions. Although $\mathrm{Zn}$ fixation has been attributed to lattice substitution (Elgabaly, 1950), clay adsorption of $\mathrm{Zn}$ without fixation is most likely an exchange process (Reddy and Perkins, 1974).

Phosphorus application did not affect the distribution of $\mathrm{Zn}$ in various $Z n$ fractions in any of the soils studied (Tables $4.3 .3,4.3 .4$ and 
4.3.5). Stanton and Burger (1970) and Bolland et al. (1977) have shown that $P$ addition enhances $Z n$ adsorption on iron and aluminum oxides. In contrast to these studies, $\mathrm{Zn}$ in the $\mathrm{FeOX}$ iraction was not af ected by fertilization in the present study. Cavaliaro (1982) found lower Zn adsorption following phosphate saturation of the soil clay surfaces.

The distribution of $\mathrm{Zn}$ in EX, MnOX and RES fractions remained almost unaffected with time (Tables $4.3 .3,4.3 .4$ and 4.3 .5 ). The ExAD and OM Zn fractions tended to decrease with time with concomitant increases in Zn associated with $F \in O X$ fractions, particularly in the Sutherland soi? (Table 4.3.5). Though values decreased with time, the reduction was great only at the maturity stage. These results indicate that part of $\mathrm{Zn}$ released from EXAD and OM fractions was taken up by plants and a part went to the Feox fraction.

The limited number of soils did not permit a statistical assessment of relationships between $\mathrm{Zn}$ uptake and the various $\mathrm{Zn}$ fractions. The

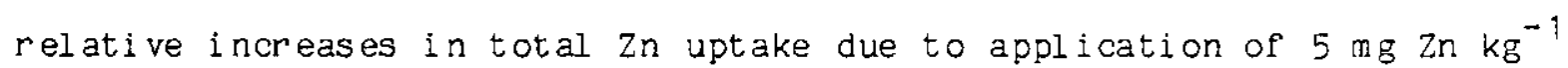
of the Carrot River and Sutherland soils were 134 and $75 \%$ and 67.9 and $29.0 \%$ at $1 / 10$ bloom stage and maturity, respectively. These results seem to indicate that EX and EXAD $\mathrm{Zn}$ fractions were the most available forms of Zn since the $C$ arrot $R$ iver soils had higher $Z n$ contents in these fractions compared to the Sutherland soil. Plant uptake of 2 n was primarily related to the exchangeable fraction (Sims, 1986). Iyengar et al. (1981) found that the adsorbed and organicalıy bound $\mathrm{Zn}$ were more available than that occluded in Fe or Mn oxides. However, in the present study OM Zn fraction does not seem to contribute significantly to plant uptake as the zn uptake in Sutherland soil was less in spite of high values for the om fraction. 


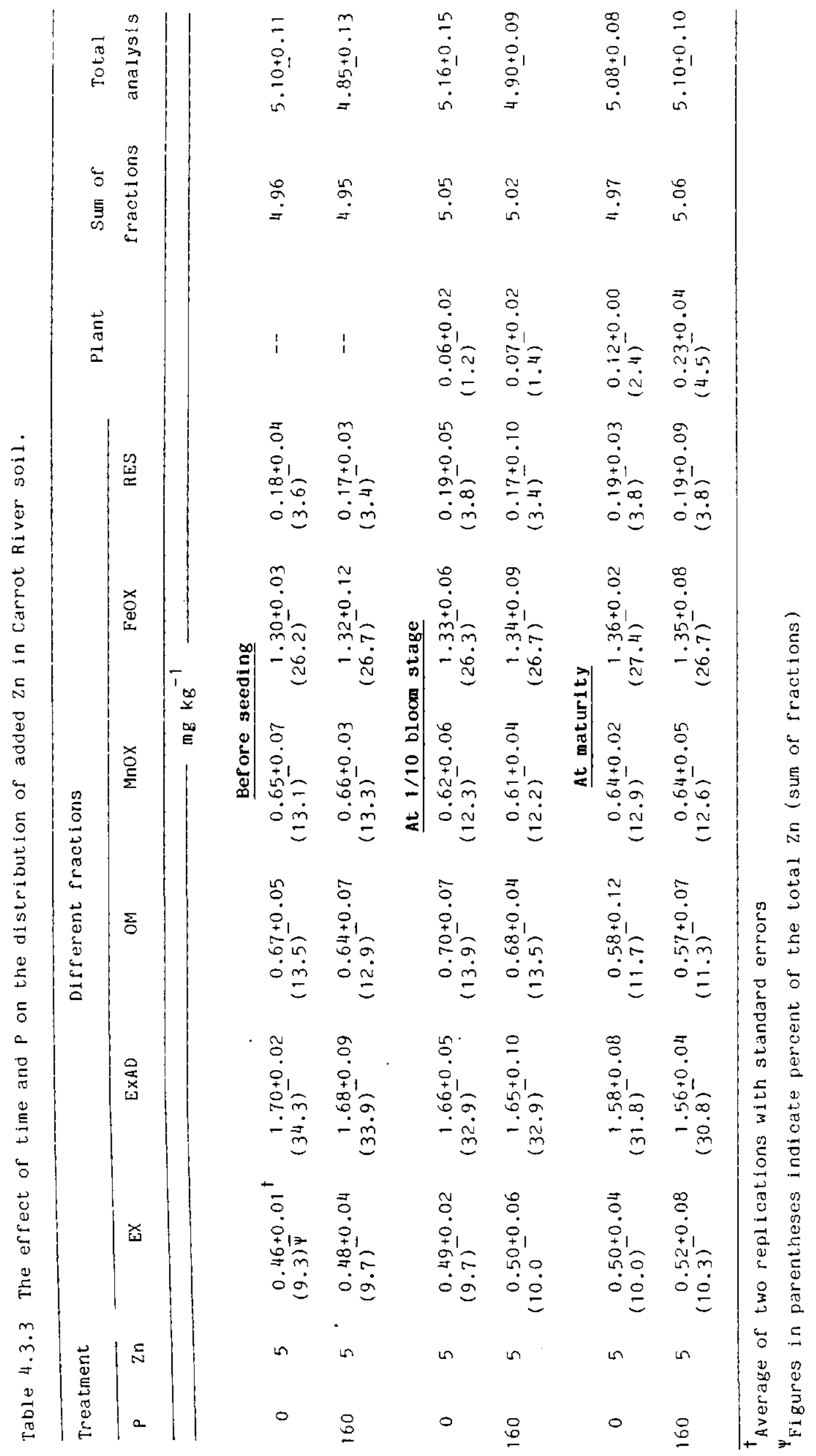




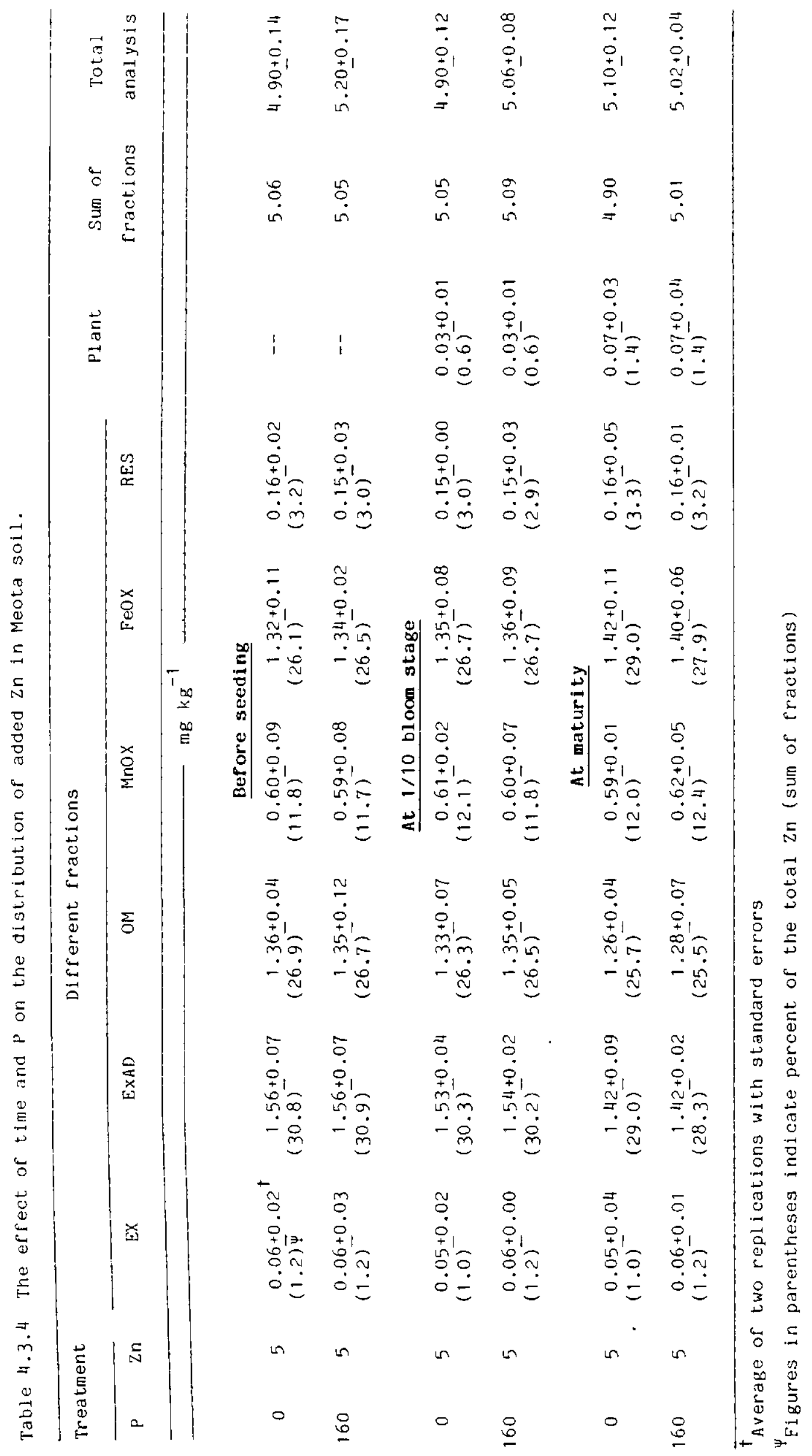




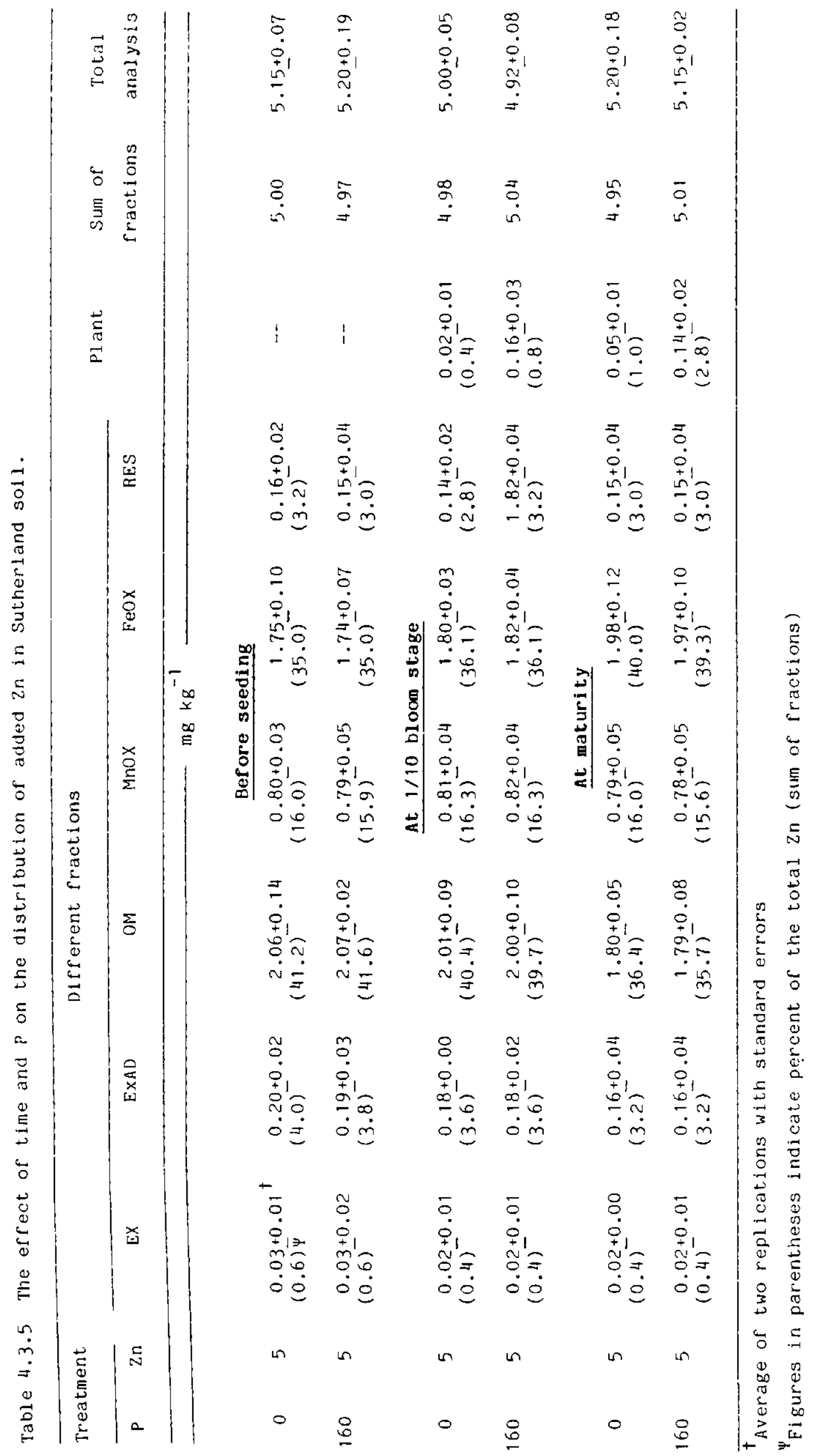




\section{SUMMARY AND CONCLUSIONS}

The objectives of this thesis were: (i) to study the spatial variability of $\mathrm{Zn}$ in Saskatchewan soils of both uniform and undulating topographies; (ii) to examine the importance of $\mathrm{Zn}$ in crop nutrition and production of common crops in Saskatchewan, and (iii) to understand the transformations of native and added $\mathrm{zn}$ in soils and their distribution among different soil Zn fractions in relation to plant availability. To meet these objectives several field, growth chamber and Iaboratory studi es were conducted.

DTPA-extractable micronutrients ( $\mathrm{Zn}, \mathrm{Cu}, \mathrm{Mn}$ and $\mathrm{Fe}$ ) in fields of level topography showed a high degree of variability in samples taken along transects and geostatistical analyses (semivariograms) indicated that the extractabie micronutrients were randomly distributed. In contrast, DTPA-extractable $\mathrm{Zn}$ and tissue $\mathrm{Zn}$ concentration in undulating topography showed spatial structure with a range of $25 \mathrm{~m}$ in all except one of the transects considered. DTPAextractable $\mathrm{Zn}$ and organic $\mathrm{C}$ levels were highly correlated and had similar spatial structure.

DTPA-extractable $\mathrm{Zn}$ levels from approximately $1200 \mathrm{fields}$ from various parts of Saskatchewan were compiled using soil samples submitted by individual farmers to the Saskatchewan Soil Testing Laboratory (SSTL) and others collected by our research team from the field research site. Soils in the populations studied were classified into three groups arbitrarily on the basis of DTPA-extractable $\mathrm{Zn}$. Class 1 (<0.5 $\mathrm{mg} \mathrm{Zn} \mathrm{kg}^{-1}$ soil) included soil samples with $\mathrm{Zn}$ levels bel ow the critical level adopted by the SSTL. Class 2 included $\mathrm{an}$ 
levels in the marginal range $\left(0.5-1.0 \mathrm{mg} \mathrm{Zn} \mathrm{kg}^{-1}\right.$ soil) and Class 3 adequate levels (>1.0 $\mathrm{mg} \mathrm{Zn} \mathrm{kg}^{-1}$ soil) of DTPA-extractable $\mathrm{Zn}$. DTPA-extractable $\mathrm{Zn}$ levels in $12 \%$ of the population examined had $\mathrm{Zn}$ levels below the critical level of $0.5 \mathrm{mg} \mathrm{kg}^{-1}$ (class 1), while approximately $37 \%$ belonged to Class 2 .

The validity of the DTPA-extractable $Z n$ test was evaluated in field experiments. Zinc fertilizers in various forms were applied to soils belonging to the three DTPA-extractable $\mathrm{Zn}$ classes prior to seeding or to the foliage of growing crops. In none of the 23 field trials conducted with various crops was there a response to $\mathrm{Zn}$ fertilization except in one with corn. Soil applied Zn-sulfate had residual effects as demonstrated by DTPA-extractable soil 2 n levels. However, there was no yi eld response to residual soil $\mathrm{Zn}$ levels.

The relative effectiveness of $2^{2} \mathrm{SO}_{4}$, ZnEDTA, low-yield ammoni um-based lignosul phonate (ZnLY) and high-yield sodium-based lignosul phonate (ZnHY) for beans production was tested in two growth chamber experiments. In the first experiment, $\mathrm{Zn}$ in organic forms was applied at a rate of $2.5 \mathrm{mg} \mathrm{kg}^{-1}$ soil and $\mathrm{ZnSO}_{4}$ form at $5 \mathrm{mg} \mathrm{kg} \mathrm{kg}^{-1}$ soil. A check treatment wi thout $\mathrm{Zn}$ was included for each source. In the second experiment, $\mathrm{ZnSO}_{4}$ and $\mathrm{ZnLY}$ were applied at four rates $(0$, $0.5,2.5$ and $5.0 \mathrm{mg} \mathrm{zn} \mathrm{kg}^{-1} \mathrm{soil}$ ). In the incubation experiment, four soils were treated with $10 \mathrm{mg} \mathrm{Zn} \mathrm{kg}^{-1}$ soil in the form of $\mathrm{znSO}_{4}$, ZnEDTA, ZnLY or ZnHY. Results of the growth chamber and incubation experiments indicated that ZnLY was more effective than ZnEDTA and ZnHY in correcting $\mathrm{Zn}$ deficiency of bean plants. Further while biomass production was best with $\mathrm{ZnSO}_{4}$, $\mathrm{ZnLY}$ was more effective in increasing $\mathrm{Zn}$ content in the foliage. 
CIear evidence of $\mathrm{Zn}$ deficiency in wheat was recorded in previous work at one field site due to large applications of $P$ and their residual effect. One-time heavy applications of $P$ on Chernozemic soils can provide sufficient available $P$ to sustain crop production over a period of several years, but may cause zn nutritional problem for crops. Therefore, studies were conducted to determine the effect of $\mathrm{Zn}$ applied to wheat grown on residual $\mathrm{P}$ plots in the field and both $P$ and $Z n$ applied to beans, in a growth chamber study .

The field study was conducted in 1984, in a continuous wheat system, on a Sutherland soil (Dark Brown Chernozemic) that had received 0,80 and $160 \mathrm{~kg} \mathrm{Pha}^{-1}$ in 1979. Three experiments were carried out using a split plot randomized complete block design with three levels of $P$ as main plots and rates of soil applied Zn-sulfate $\left(0,5,10\right.$ and $\left.20 \mathrm{~kg} \mathrm{Zn} \mathrm{ha}{ }^{-1}\right)$ or $\mathrm{Zn}$-chelate $(0,0.5,1.0$, and $2.0 \mathrm{~kg} \mathrm{zn}$ $\mathrm{na}^{-1}$ ) or foliar applied Zn-chelate ( 0 and $0.35 \mathrm{~kg} \mathrm{Zn} \mathrm{na}{ }^{-1}$ ) as subplots.

A one-time application of 80 or $160 \mathrm{~kg} \mathrm{P} \mathrm{ha}^{-1}$ increased wheat yield significantly. In the presence of $P$, application of $Z$ n resulted in a significant increase in grain yield and in $\mathrm{Zn}$ uptake into grain. Applied $P$ increased soil $P$ and tissue $P$ concentration, but resulted in a significant decrease of tissue $\mathrm{Zn}$ concentration. DTPA-extractable soil $\mathrm{Zn}$ levels in the non-Zn amended treatment were independent of $P$ application rate. Plant roots in high $P$ treatments contained significantly lower levels of vesicular-arbuscular mycorrhizal (VAM) infection than the control. Further, a close relationship was observed between $\mathrm{Zn}$ levels in the above ground plant parts and VAM infection. 
Interactions of soil applied $P\left(0,40,80\right.$ and $\left.160 \mathrm{mg}^{32} \mathrm{p} \mathrm{kg}^{-1}\right)$ and $\mathrm{Zn}\left(0,5\right.$ or $\left.10 \mathrm{mg}{ }^{65} \mathrm{Zn} \mathrm{kg}^{-1}\right)$ in roots and above ground portions of bean at two growth stages were studied in the Sutherland (Dark Brown Chernozemic), Carrot River (Dark Cray Chernozemic) and Meota (Black Chernozemic) soils in the growth chamber. The $P X Z$ Zn interaction on dry matter yield of above ground parts was significant for the Sutherland and Carrot River soils only. This interaction was expressed by larger yield responses to $\mathrm{P}$ when $\mathrm{Zn}$ was applied. The $\mathrm{Zn}$ concentration in tops was significantly reduced due to $p$ application and the magnitude of reduction was greatest for the first inorement of added $\mathrm{P}\left(40 \mathrm{mg} \mathrm{P} \mathrm{kg}^{-1}\right)$. Translocation of $\mathrm{Zn}$ from roots to tops was inhibited in the 80 and $160 \mathrm{mg} \mathrm{P} \mathrm{kg}^{-1}$ treatments, as evidenced by reduction of $\mathrm{Zn}$ uptake into tops of non-Zn treatments. Plant dilution effects and reduced translocation of $\mathrm{Zn}$ from roots to tops were the two mechanisms responsible for the observed $\mathrm{P}$-induced $\mathrm{Zn}$ deficiency in this study.

Added $P$ increased the concentration and uptake of $P$ in all plant parts at both growth stages in all soils. Increasing levels of Zn generally decreased the $P$ concentration and uptake in the above ground plant parts. Root $P$ concentration and uptake, however, increased with $\mathrm{Zn}$ application in the Sutherland and Carrot River soils only at $1 / 10$ bloom stage. The increase in $P$ concentration in the above ground plant parts was of greater magnitude with 80 or $160 \mathrm{mg} P$ $\mathrm{kg}^{-1}$ treatments in the absence than in the presence of applied $\mathrm{Zn}$ in the Sutherland and Carrot River soils. Thus $Z$ n deficiency markedly enhanced $P$ absorption by roots, transport and accumulation of $P$ in above ground plant parts. However, $P$ levels in bean tissue did not 
reach reported toxicity levels.

The $Z n$ derived from applied source ( ${ }^{\prime}$ Zndff) was affected by soil properties and the native labile pool of $\mathrm{Zn}$. Depending on the $\mathrm{P}$ level, plant part and growth stage, 22.7 to $55.4 \%, 41.9$ to $59.5 \%$ and 7.9 to $44.6 \%$ of $\mathrm{Zn}$ was derived from the applied source by beans in the Sutherland, Carrot River and Meota soils, respectively. The of Zndff was generally decreased in roots with $P$ application whereas it was increased in the above ground portions of beans grown on the Sutherland and Carrot River soils only. Phosphorus application

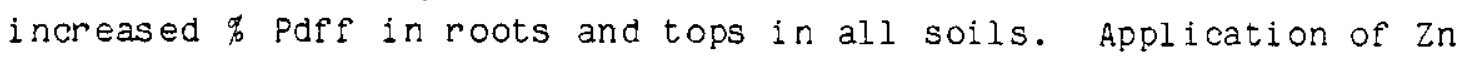
generally decreased the \% Pdff in plant tops but increased it in the roots.

The distribution of native and applied $\mathrm{Zn}$ was studied in the Sutherland, Carrot River and Meota soils used for $P$ X Zn experiment with beans. The distribution of added $\mathrm{Zn}\left(5 \mathrm{mg}^{65} \mathrm{Zn} \mathrm{kg}^{-1}\right)$ was studied under two $\mathrm{P}$ treatments ( 0 and $160 \mathrm{mg} \mathrm{P} \mathrm{kg}^{-1}$ ) and soil samples were analyzed before seeding, after $1 / 10$ bloon stage, and after harvesting the beans at maturity.

Total Zn was fractionated sequentially into water soluble plus exchangeable (EX), specifically adsorbed (ExAD), organically bound (OM), Mn-oxide bound (MnOX), Fe-oxide bound (FeoX) and residual (RES) forms. Most of the native $\mathrm{Zn}$ was present in RES (66.6\%) and FeOX (23.9\%) fractions. Among the three soils studied, the Sutheriand soil had greater amounts of $Z$ n in RES fraction compared to the Carrot River and Meota soils. The percentage of $\mathrm{Zn}$ in EX, EXAD, OM and MnOX fractions averaged $0.2,0.7,7.0$ and $1.4 \%$, respectively. Added $Z n$ was relatively higher in EX or EXAD fractions in the 
Carrot River (9.3\% or $34.3 \%$ ) and Meota (1.2\% or 30.8\%) soils compared with the sutherland soil $(0.6 \%$ or $4.0 \%)$. In the sutherland soil, most of the applied $Z n$ was recovered in the $O M(41.2 \%)$ and FeoX (35\%) fractions. Very small amounts $(3.2$ to $3.6 \%)$ of appiied $\mathrm{Zn}$ were associated with the RES fraction in all soils.

Addition of $P$ did not affect the distribution of $Z n$ in different forms in any of the soils studied. The OM, MnOX and $E$ eOX fractions of the applied $\mathrm{Zn}$ in all soils varied directly with organic carbon, Mn- and Fe-oxide contents of the soils. Distribution of $\mathrm{Zn}$ in different fractions in three soils and $\mathrm{Zn}$ plant uptake data tended to indicate that plant uptake was primarily related to water soluble plus exchangeable and specifically adsorbed fractions.

The major conclusions of this thesis are as follows:

1. Under current cropping systems $Z$ n deficiency in crops is not Iikely to occur in Saskatchewan, with the possible exception of special crops in localized areas or in soils with low levels of $2 n$ where heavy applications of $P$ are made.

2. Although a one-time application of 1 arge amounts of $P$ on certain soils can provide sufficient available $p$ to sustain crop production over a period of several years, it can also lead to $\mathrm{Zn}$ disorders in crops. In Saskatchewan, soil application of $10 \mathrm{~kg} \mathrm{zn}$ as Znso ha ${ }^{-1}$ or foliar application of $0.35 \mathrm{~kg} \mathrm{Zn}$ as $\mathrm{Zn}$-chelate ha ${ }^{-1}$ are suggested as effective means of alleviating the adverse effect of high residual $P$ in soil.

3. P-induced $Z n$ deficiency observed in wheat and beans was found to be the result of plant dilution effects and physiological effects enhanced by reduced mycorrhizal infection. Neither $P X \mathrm{Zn}$ 
interaction in the soil nor $P$ toxicity in plant tops have been observed.

4. Examination of the forms and distribution of $2 n$ in three representative Saskatchewan soils indicated that the water soluble pl us exchangeable and the specifically adsorbed fractions are of importance in assessing plant $2 n$ availability. Therefore, selection of extractants to i dentify $\mathrm{Zn}$ deficient soils should be based on the extractant's effectiveness in identifying these fractions. The DTPA soil test can be used successfully to determine the available $z$ in sandy soils. However this test may not be successful in clayey soil. Hence, current soil testing criteria for the assessment of available Zn in Saskatchewan soils must be revised. The revision must proceed in two major directions, namely, (i) prediction of the $\mathrm{Zn}$ fertility of soils in which heavy rates of $P$ have been or are being applied, and (ii) prediction of the Zn fertility of various types of Saskatchewan soils or crops other than small grain cereals.

5. Proper interpretation of soil $\mathrm{Zn}$ tes's as well as of $\mathrm{Zn}$ field experimentation requires knowledge of the spatial variability of this nutrient in the field. Knowledge of the spatial variability of Zn in fields containing levels of $\mathrm{Zn}$ well above the critical level bears no significance to assessing the $2 n$ fertility. However, at soil Zn levels near the critical level, knowledge of the spatial variability can prove an asset in determining fertilizer requirements in field research experiments. It is highly unlikely that in a routine soil testing program it will be possible to take sufficient samples to achieve high level of precision for $\mathrm{Zn}$. However, current soil sampling practices recommended by the Saskatchewan Soil Testing 
Laboratory appear to be adequate.

6. A great portion of the variation as well as spatial distribution of $\mathrm{Zn}$ can be inferred from that of organic $C$ levels. This could be of major significance in assessing the $z$ n status of soils on a per map unit or soil site basis. 


\section{BIBLIOCRAPHY}

Abd-Elfattah, A. and K. Wada. 1981. Adsorption of lead, copper, zinc, cobalt, and cadmium by soils that differ in cation exchange materials. J. Soil sci. 32: 271-283.

Allen, S.E., G.L. Terman and L.B. Clements. 1976. Greenhouse techniques for soil-plant fertilizer research. National Fertilizer Development Centre, Tennessee Valley Authority, Muscle Shoals, Alabama, Bull. Y-104.

Ambler, J.E. and J.C. Brown. 1969. Causes of differential susceptibility to zinc deficiency in two varieties of navy beans (Phaseolus vulgaris L.). Agron. J. 61: 41-43.

Anderson, W.B. 1964. Effectiveness of synthetic chelating agents as sources of zinc on calcareous soils. Diss. Abstr. 25: $3193-3194$

Andriano, D.e., G.M. Paulsen and L.S. Murphy. 1971. Phosphorus-iron and phosphorus-zinc relationships in corn (zea mays L.) seedlings as affected by mineral nutrition. Agron. J. 63: 36-39.

Aubert, H. and M. Pinta. 1977. Zinc. In Trace Elements in Soils. Elsevier Scientific Publishing Company, New York. 395 pp. Barrow, H.L., M.S. Neff and N. Gammon. 1960. Effect of soil type on mobility of zinc in the soil and on its availability from zinc sulfate to tung. Soil Sci. Soc. Am. Proc. $24: 367-372$.

Barrow, N.J., J.W. Bowden, A.M. Posner and J.P. Quirk. 1981. Describing the adsorption of copper, zinc and lead on variable charge mineral surface. Aust. J. Soil Res. 19: 309-321. 
Bascomb, C.L. 1968. Distribution of pyrophosphate-extractable iron and organic carbon in soils of various groups. J. Soil Sci. $19: 251-268$.

Bates, T.E. 1971. Factors affecting critical nutrient concentration in plants and their evaluation: A review. Soil Sci. 112: $116-130$

Benson, N.R. and R.P. Covey. 1976. Response of apple seedlings to zinc fertilization and mycorrhizal inoculation. J. Am. Soc. Hort. Sci. 11: 252-253.

Bingham, F.T. 1963. Relation between phosphorus and micronutrients in plants. Soil Sci. Soc. Am. Proc. $27:$ 389-391.

Bingham, F.T., A.L. Page and J.R. Sims. 1964. Retention of Cu and $\mathrm{Zn}$ by H-montmorilionite. Soil Sci. Soc. Am. Proc. 28: 351-354.

Boawn, L.C. 1973. Comparison of zinc sulfate and zinc EDTA as zinc fertilizer sources. Soil Sci. Soc. Am. Proc. 37: 111-115.

Boawn, L.C. and J.C. Brown. 1968. Eurther evidence for a P-Zn imbalance in plants. Soil Sci. Soc. Am. Proc. 32: 94-97. Boawn, L.C. and G.E. Leggett. 1963. Zinc deficiency of the Russett Burbank potato. Soil Sci. 95: 137-141.

Boawn, L.C. and G.E. Leggett. 1964. Phosphorus and zinc concentrations in Russett burbank potato tissue in relation to development of zinc deficiency symptoms. Soil Sci. Soc. Am. Proc. 28: 229-232.

Boawn, L.C., F.G. Viets, Jr. and C.L. Crawford. 1954. Effect of phosphate fertilizers on zinc nutrition of field beans. Soil Sci. $78: 1-7$. 
Boawn, L.C., F.G. Viets, ir. and C.L. Crawford. :957. Plant utilization of zine from various types of zinc compounds and fertilizer materials. Soil sci. 83: 219-227.

Boawn, L. C., F.G. Viets, Jr., C.L. Crawf ord and J.L. Nelson. 1960. Effect of nitrogen carrier, nitrogen rate, zinc rate and soil pH on zinc uptake by sorghum, potatoes, and sugarbeets. Soil Sci. $90: 329-337$.

Bolland, M.D.A., A.M. Posner and J.P. Quirk. 1977. Zinc adsorption by goethite in the absence and presence of phosphate. Aust. J. Soil Res. 15: 279-286.

Bowen, J.E. 1969. Adsorption of copper, zinc, and manganese by sugarcane leaf tissue. Plant Physiol. 44: 255-261.

Brown, A.L. and B.A. Krantz. 1966. Sources and placement of zinc and phosphorus for corn (Zea mays L.). Soil Sci. Soc. Am. Proc. $30: 86-89$.

Brown, A.L., B.A. Krantz and J.L. Eddings. - 1970. Zine-phosphorus interactions as measured by plant response and soil anaiysis. Soil Sci. 110: 415-420.

Brown, A.L., B.A. Krantz and P.E. Martin. 1962. Plant uptake and fate of soil-applied zinc. Soil Sci. Soc. Am. Proc. 26: $167-170$

Brown, A.L., J. Quick and J.L. Eddings. 1971. A comparison of analytical methods for soil zine. Soil Sci. Soc. Am. Proc. 35: 105-107. 
Brown, J.C., J.E. Ambler, R.t. Chaney and C.D. Foy. 1972.

Differential responses of plant genotypes to micronutrients. Pages 389-418. In J.J. Morvedt, P.M. Giordano and W.L. Lindsay (eds.) Micronutrient in Agriculture. Soil Sci. Soc. Am., Madison, Nis.

Brummer, G., K.G. Tiller, U. Herms and P.M. Clayton. 1983. Adsorption-desorption and/or preciptation-dissolution processes of zinc in soils. Geoderma $31: 337-354$.

Carroll, M.D. and J.F. Loneragan. 1969. Response of plant species to concentration of zinc in solution. II. Rates of zinc absorption and their relation to growth. Aust. J. Agric. Res. $20: 457-463$

Cavallaro, N. 1982. Sorption and fixation of $\mathrm{Cu}, \mathrm{Zn}$ and phosphate by soil clays as influenced by the oxide fraction. Ph.D. Thesis, Corneli Univ. (Diss. Abstr. 82: 10799).

Cavallaro, N. and M.B. McBride. 1984. Zinc and copper sorption and fixation by an acid soil clay: effect of selective dissolutions. Soil Sci. Soc. Am. J. 48: 1050-1054.

Chao, T.T. 1972. Selective dissolution of manganese oxides from soils and sediments with acidified hydroxylamine hydrochloride. Soil Sci. Soc. Am. Proc. 36: 764-768.

Chapman, H.D. 1966. Zinc. Pages 484-499. In H.D. Chapman (ed.) Diamostic Criteria for Plants and Soils. University of Cal ifornia, Berkeley.

Crepin, J. 1983. Background to micronutrient requirements in Alberta. Pages 45-52. In Proc. Soils and Crops workshop, Extension Division, Univ. of Saskatchewan, Saskatoon, Sask. 
Cooper, K.M. and P.B. Tinker. 1978. Translocation and transfer of nutrients in vesicular-arbuscular mycorrhizas. New Phytol. 81: $43-52$.

De Encredy, A.S. :963. Estimation of free ferric oxides in soils and clays by a photolytic method. Clay Miner. Bull. 5: 209-217.

Demeterio, J.L., E.J. Roscoe and G.M. Paulsen. 1972. Nodulation and nitrogen fixation by two soybean varieties as affected by phosphorus and zinc nutrition. Agnon. J. 64: 566-568.

DeMumbrum, L.E. and M.L. Jackson. 1956a. Copper and zinc exchange from dilute neutral solutions by soil colloidal electrolytes. Soil Sci. 81: 353-357.

DeMumbrum, L.E. and M.L. Jackson. 1956b. Infrared absorption evidence on exchange reaction mechanisms of copper and zinc with layer silicate clays and peats. Soil Sci. Soc. Am. Proc. $20: 334-337$

Edlin, V.M., R.E. Karamanos and E.H. Halstead. 9983. Evaluation of soil extractants for determining $\mathrm{Zn}$ and $\mathrm{Cu}$ deficiencies in Saskatchewan soils. Commun. Soil Sci. Plant Anal. 14: $1167-1179$.

Edwards, J.H. and E.J. Kampratr. 1974. Zinc accumlilation by corn seedlings as influenced by phosphorus, temperature and light intensity. Agron. J. 66: 479-482.

Elgabaly, M.M. 1950. Mechanism of zinc fixation by colloidal clays and related minerals. Soil Sci. 69: 167-174.

Elgawhary, S.M., W.L. Lindsay and W.D. Kemper. 1970. Effects of complexing agents and acids on the diffusion of zinc to a simulated root. Soil Sci. Soc. Am. Proc. 34: 211-214. 
Ellis, B.G., J.F. Davis and W.H. Judy. 1965a. Effect of method of incorporation of zinc fertilizer on zinc uptake and yield of pea beans (Phaseolus vulgaris L.) Soil Sci. Soc. Am. Proc. 29: $635-636$.

Ellis, B.G. and B.D. Knezek. 1972. Adsorption reactions of micronutrients in soils. Pages 59-78. In J.J. Mortvedt, P.M. Giorando and W.L. Lindsay (eds.) Micronutrients in Agriculture. Soil Sci. Soc. Am., Madison, wis.

Ellis, J.G., D.F. Acton and J.S. Clayton. 1965b. The Solis of the Regina Map Area. Sask. Institute of Pedology Publ. S1, University of Saskatchewan, Saskatoon, Sask.

Farhoomand, M.B. and L.A. Peterson. 1968. Concentration and content. Agron. J. 60: 708-709.

Farrah, H. and W.F. Pickering. 1977. Influence of clay-solute interactions on aqueous heavy metal ion levels. Water Air soil Pollut. 8: 189-197.

Forbes, E.A., A.M. Posner and J.P. Quirk. 1976. The specific adsorption of divalent $\mathrm{Cd}, \mathrm{Co}, \mathrm{Cu}, \mathrm{Pb}$ and $\mathrm{Zn}$ on goethite. $\mathrm{J}$. Soil Sci. $27: 154-166$.

Gallagher, P.J., L.S. Murphy and R. Ellis, Jr. 1978. Effect of temperature and soil pH on effectiveness of four zinc fertilizers. Commun. Soil Sci. Plant Anal. 9: 127-139. Giordano, P.M. and J.J. Mortvedt. 1978. Response of corn to $\mathrm{Zn}$ in ortho- and pyrophosphate fertilizers, as affected by soil temperature and moisture. Agron. J. 70: 531-534. 
Gladstones, J.S. and J.F. Loneragan. 1967. Mineral elements in temperate crop and pasture plants. I. Zinc. Aust. J. Agric. Res. $18: 427-446$.

Goh, T.B., A. Violante and P.M. Huang. 1983. The influence of tannic acid and aging on the retention of $\mathrm{Cu}$ and $\mathrm{Zn}$ by the hydrolytic products of Al. Agron. Abstrs., p. 218.

Halim, A.H., C.E. Wassom and R. Ellis, Jr. 1968. Zinc depiciency symptoms and zinc and phosphorus interaction in several strains of corn (Zea mays L.). Agron. J. 60:267-271.

Halvin, J.L. and P.N. Soltanpour. 1981. Evaluation of the $\mathrm{NH}_{4} \mathrm{HCO}_{3}-$ DTPA soil test for iron and zine. Soil Sci. Soc. Am. J. 45: $70-75$.

Halvorson, A.D. and A.L. Black. 1985a. Longterm dryl and crop responses to residual phosphorus fertilizer. Soil Sci. Soc. Am. J. $49: 928-933$.

Halvorson, A.D. and A.L. Black. 1985b. Fertilizer phosphorus recovery after seventeen years of dryland cropping. Soil Sci. Soc. Am. J. 49: 933-937.

Halvorson, A.D. and W.L. Lindsay. 1977. The critical $\mathrm{Zn}^{2+}$ concentration for corn and the nonabsorption of chelated zinc. Soil Sci. Soc. Am. J. 41:531-534.

Haq, A.L. and M.H. Miller, 1972. Prediction of availabie soil $\mathrm{Zn}$, $\mathrm{Cu}$, and Mn using chemical extractants. Agron. J. 64: 779-782. Harter, R.D. 1983. Effect of soil pH on adsorption of lead, copper, zinc and nickel. Soil sci. Soc. Am. J. 47: 47-51. 
Hayman, D.S. 1978. Mycorrhizal populations of sown pastures and native vegetation in Otago, New Zeal and. New Zealand J. Agric. Res. 21: 271-276.

Hedley, M.J., J.W.B. Stewart and B.S. Chauhan. 1982. Changes in inorganic and organic soil phosphorus fractions induced by cultivation practices or by laboratory incubations. Soil Sci. Soc. Am. J. $46: 970-976$.

Heeney, H.B., G.M. Ward and W.M. Rutherford. 1964. Zinc deficiency in eastern ontario orchards. Can. J. Plant Sci. 44: 195-200. Hilton, B.R. and J.C. Zubriski. 1985. Effect of sulfur, zine, iron, manganese, and boron applications on sunflower yield and plant nutrient concentration. Commun. Soil Sci. Plant Aral. 16: 399-409.

Hochberg, M. and N. Lahav. 1978. Movement of iron and zinc applied on EDTA complexes in soil columns. Plant soil 50:221-225. Hodgson, J.F. 1963. Chemistry of the micronutrient elements in soils. Adv. Agron. 15: 119-159.

Hodgson, J.F., H.R. Geering and W.A. Norvell. 1965. Micronutrient cation complexes in soil solution: Partition between complexed and uncomplexed forms by solvent extraction. Soil Sci. Soc. Am. Proc. 29: 665-669.

Hodgson, J.F., W.L. Lindsay and J.E. Trierweiler. 1966. Micronutrient cation complexing in soil solution. II. Complexing of zinc and copper in displaced solution from calcareous soils. Soil Sci. Soc. Am. Proc. 30:723-727. 
Iyengar, B.R.V. and D.L. Deb. 1977. Contribution of soii zinc fractions to plant uptake and fate of zinc applied to the soil. J. Indian Soc. Soil Sci. 25: 426-432.

Iyengar, S.S., D.C. Martens and W.P. Milier. 1981. Distribution and plant availability of soil zinc fractions. Soil Sci. Soc. Am. J. $45: 735-739$.

Jacobson, B.S., F. Fong and R.L. Heath. 1975. Carbonic anhydrase of spinach. Studies on its location, inhibition and physiological function. Plant Physiol. 55: 468-474.

Jacques, G.L., R.L. Vanderlip and R. Ellis, Jr. 1975. Growth and nutrient accumulation and distribution in grain sorghum. II. Zn, Cu, $F e$ and $M n$ uptake and distribution. Agron. J. 67: $611-616$

Jenne, E.A. 1968. Controls of $\mathrm{Mn}, \mathrm{Fe}, \mathrm{Co}, \mathrm{Ni}, \mathrm{Cu}$ and $\mathrm{Zn}$ concentration in soils and water: The significant role of hydrous $\mathrm{Mn}$ and Fe oxides. In R.A. Baker (ed.) Trace Inorganics in water. Adv. Chem. Ser. $73: 337-387$.

Jones, J.B. 1972. Plant tissue analysis for micronutrients. Pages 319-346. In J.J. Mortvedt, P.M. Giordano and W.L. Lindsay (eds.), Micronutrients in Agriculture. Soil Sci. Soc. Am., Madison, wis.

Journel, A.G. and C.J. Huijbregts. 1978. Mining Geostatistics. Academic Press, New York.

Jurinak, J.J. and T.S. Inouye. 1962. Some aspects of zinc and copper phosphate formation in aqueous systen. Soil Sci. Soc. Am. Proc. 26: $144-147$. 
Jyung, W.H., A. Ehmann, K.K. Schlender and J. Scala. 1975. Zinc nutriton and starch metabolism in Physeolus vulgaris L. Plant Physiol. 55: $414-420$.

Kachanoski, R.G. 1984. Spatial and spectral relationships between soil and soil forming factors. Ph.D. Thesis, Dept. Land, Air, Water Resources, Univ. of California, Davis, Calif.

Kalbasi, M., G.J. Racz and L.A. Loewen-Rudgers. 1978. Mechanism of zinc adsorption by iron and aluminum oxides. Soil sei. 125: $146-150$

Kal yanasundaram, N.K. and B.V. Mehta. 1970. Availability of zinc, phosphorus, and calcium in soils treated with varying levels of zinc and phosphate - a soil incubation study. Plant soil 33: $699-706$.

Kanwar, J.S. and R.E. Youngdahl. 1985. Micronutrient needs of tropical food crops. Fertilizer Research 7:69-94.

Karamanos, R.E., J.C. Fradette and P.D. Gerwing. 1985. Evaluation of copper and manganese nutrition of spring wheat grown on organic soils. Can. J. Soil Sci. $65: 133-148$.

Karamanos, R.E., G.A. Kruger and J.L. Henry. 1984a. Evaluation of plant tissue criteria for predicting manganese deficiency in oats. Can. J. Plant Sci. 64: 863-868.

Karamanos, R.E., G.A. Kruger and J.P. Singh. 1984b. The micronutrient status of Saskatchewan soils. Presented at 27th Annual Manitoba Society of Soil Science Meetings, January, Winni peg, Man. 
Karamanos, R.E., G.A. Kruger and J.W.B. Stewart. 1986. Copper deficiency in cereal and oilseed crops in Northern Canadian prairie soils. Agron. J. 78: $317-323$.

Keefer, R.F. and R. Estepp. 1971. The fate of zinc-65 applied to soils as zinc sulfate and zinc-EDTA. Soil Sci. 112: 325-329.

Khan, A. and P.N. Soltanpour. 1978. Effect of wetting and drying on DTPA-extractable Fe, $\mathrm{Zn}, \mathrm{Mn}$ and $\mathrm{Cu}$ in soils. Conmun. Soil Sci. Plant Anal. 9: 193-202.

Khan, M.A. and S. Nortcliff. 1982. Variability of selected soil micronutrients in a single soil series in Berkshire, England. J. Soil Sci. 33: 763-770.

Kinniburgh, D.G. 1983. The $\mathrm{H}^{+} / \mathrm{M}^{2+}$ exchange stoichiometry of cal cium and zinc adsorption by ferrinydrite. J. Soil Sci. 34:759-768. Kinniburgh, D.G. and M.L. Jackson. 1982. Concentration and pH dependence of calcium and zinc adsorption by iron hydrous oxide gel. Soil Sci. Soc. Am. J. 46:56-6i.

Kinniburgh, D.G., M.L. Jackson and J.K. Syers. 1976. Adsorption of alkaline earth, transiton, and heavy metal cations by hydrous oxide gels of iron and aluminum. Soil Sci. Soc. Am. J. 40: $796-799$.

Kittrick, J.A. 1976. Controls of $\mathrm{Zn}^{2+}$ in the soil solution by sphalerite. Soil Sci. Soc. Am. J. 40: 314-317.

Krauskopf, K.B. 1972. Geochemistry of mi cronutrients. Pages 7-40. In J.J. Mortvedt, P.M. Giordano and W.L. Lindsay (eds.) Micronutrients in Agriculture. Soil Sci. Soc. Am., Madison, Wis. 
Kruger, G.A., R.E. Karamanos and J.P. Singh. 1985. The copper fertility of Saskatchewan soils. Can. J. Soil Sci. 55: 89-99.

Kuo, S. and D.S. Mikkelsen. 1979. Zinc adsorption by two alkaline soils. Soil sci. 128: $274-279$.

Kurdi, F. and H.E. Doner. 1983. Zinc and copper sorption and interaction in soils. Soil Sci. Soc. Am. J. 47: 873-876.

Lambert, D.H., D.E. Baker and H. Cole, Jr. 1979. The role of mycorrhizae in the interactions of phosphorus with zinc, copper and other elements. Soil sei. Soc. Am. J. 43: 976-98C.

Langin, E.J., R.C. Ward, R.A. Olson and H.F. Rhoades. 1962. Factors responsible for poor response of corn and grain sorghum to phosphorus fertilization. II. Lime and $P$ placement effects on P-Zn relations. Soil Sci. Soc. Am. Proc. 26:574-578.

Leggett, G.E. and D.P. Argyle. 1983. The DTPA-extractable iron, manganese, copper, and zinc from neutral and calcareous soils dried under different conditions. Soil Sci. Soc. Am. J. 47: $518-522$.

Lindsay, W.L. 1972. Zinc in soils and plant nutrition. Adv. Agron. $24: 147-186$.

Lindsay, W.L. 1979. Chemical Equilibria in Soils. John Wiley \& Sons, Inc., New York.

Lindsay, W.L. and W.A. Norvell. 1969. Equilibrium relationships of $\mathrm{Zn}^{++}, \mathrm{Fe}^{+++}, \mathrm{Ca}^{++}$and $\mathrm{H}^{+}$with EDTA and DTPA in soil. Soil Sci. Soc. Am. Proc. 33: 62-68.

Lindsay, W.L. and W.A. Norvell. 1978. Development of a DTPA soil test for zinc, iron, manganese and copper. Soil Sci. Soc. Am. J. 42: 421-428. 
Loewen-Rudgers, L., J.M. Tokarchuk, D.W. MCAndrew and D.W. MCKenzie. 1983. Micronutrient deficiencies in Manitoba crops. Pages 21-44. In Proc. Soils and Crops Workshop, Extension Division, University of Saskatchewan, Saskatoon, Sask.

Loganathan, P., R.G. Burau and D.W. Fuerstenau. 1977. Influence of $\mathrm{pH}$ on the sorption of $\mathrm{Co}^{++}, \mathrm{Zn}^{++}$and $\mathrm{Ca}^{++}$by a hydrous manganese oxide. Soil Sci. Soc. Am. J. 41: 57-62.

Loneragan, J.F., T.S. Grover, A.D. Robson and K. Snowball. 1979. Phosphorus toxicity as a factor in the zinc-phosphorus interactions in plants. Soil Sci. Soc. Am. J. 43: 966-972. Loneragan, J.F., D.L. Grunes, R.M. Welch, E.A. Aduai, A. Tengah, V.A. Lazar and E.E. Cary. 1982. Phosphorus accumulation and toxicity in leaves in relation to zinc supply. Soil Sci. Soc. Am. J. $46: 345-352$.

Lucas, R.E. and B.D. Knezek. 1972. Climatic and soil conditions promoting micronutrient deficiencies in plants. Pages 265-288. In J.J. Morvedt, P.M. Giordano and W.L. Lindsay (eds.) Micronutrients in Agriculture. Soil Sci. Soc. Am., Madison, wis.

MacLean, A.J., R.L. Halstead, and B.J. Finn. 1972. Effects of 1 ime on extractible aluminum and other soil properties and on barley and alfalfa grown in pot tests. Can. J. Soil Sci. 52:427-438. Marinko, M.L. and K. Igue. 1972. Factors affecting zinc absorption by corn from vol canic ash soils. Agron. J. 64: 3-8.

Martens, D.C. 1968. Plant availability of extractable boron, copper, and zinc as related to selected soil properties. Soil Sci. $106: 23-28$ 
Martens, D.C., G. Chesters and L.A. Peterson. 1966. Factors controlling the extractability of soil zinc. Soil Sci. Soc. Ain. Proc. 30:67-69.

Martin, W.E., J.E. McLean and J. Quick. 1965. Effect of temperature on the occurrence of phosphorus-induced zinc deficiency. Soil Sci. Soc. Am. Proc. 29: $411-413$.

Mashhady, A.S. 1983. Labile pools of copper and zinc in calcareous soils as measured by DTPA and plant extraction. Commun. Soil Sci. Plant Anal. 14:893-904.

Massey, H.F. and F.A. Loeffel. 1967. Factors in interstrain variation in.zinc content of maize (Zea mays L.) kernels. Agron. J. 59: $214-217$.

Matsuda, K. and S. Ito. 1970. Absorption strength of zinc for soil humus. III. Relationship between stability constants of zine humic and -fulvic acid complexes and degree of humification. Soil Sci. Plant Nutr. 16:1-10.

McBride, M.B. and J.J. Blasiak. 1979. Zinc and copper solubility as a function of $\mathrm{pH}$ in an acid soil. Soil Sci. Soc. Am. J. 43: $866-870$

McKeague, J.A. (ed.) 1978. Manual on Soil Sampling and Methods of Analysis, and edition. Can. Soc. Soil Sci., Ottawa, Ontario. Mckenzie, D.B. and R.J. Soper. 1983. Zinc regulation in blackbeans (Phaseolus vulgaris L.). Commun. Soil Sci. Plant Anal. 14: $709-725$.

McLaren, R.G. and D.V. Crawford. 1973. Studies on soil copper. I. The fractionation of copper in soils. J. Soil Sci. 24: $172-181$. 
Melsted, S.W., H.L. Motto and T.R. Peck. 1969. Critical plant nutrient composition values useful in interpreting plant anal ysis data. Agron. J. 61: 17-20.

Mengel, K. and K.A. Kirkby. 1982. Zinc. Pages 501-511. In Principles of Plant Nutrition. 3rd edition. Intern. Potash Institute, Bern, Switzerland.

Millikan, C.R., B.C. Hanger and E.N. Bjarnason. 1968. Effect of phosphorus and zinc levels in the substrate on $65 \mathrm{Zn}$ distribution in subterranean clover and flax. Aust. J. Biol. Sci. 21: 619-640.

Mitchell, J., H.C. Moss and J.S. Clayton. 1944. Soil Survey of Southern Saskatchewan. Soil Survey Report No. 12, University of Saskatchewan, Saskatoon, Sask.

Moore, D.P. 1972. Mechanisms of micronutrient uptake by plants. Pages 171-197. In J.J. Mortvedt, P.M. Giordano and W.L. Lindsay (eds.) Micronutrients in Agriculture. Soil Sci. Soc. Am. Madison, wis.

Moraghan, J.T. 1980. Effect of soil temperature on response of flax to phosphorus and zinc fertilizers. Soil Sci. 129: 290-296. Moraghan, J.T. 1985. Plant tissue testing for micronutrient deficiencies and toxicities. Fertilizer Research 7: 201-219. Murphy, J. and J.P. Riley. 1962. A modified single solution method for the determination of phosphate in natural waters. Anal. Chim. Acta $27: 31-36$.

Murphy, L.S. and L.M. Walsh. 1972. Correction of micronutrient deficiencies with fertilizers. Pages 347-387. In J.J. Mortvedt, P.M. Giordano and W.L. Lindsay (eds.) Micronutrients in Agriculture. Soil Sci. Soc. Am., Madison, wis. 
Nelson, J.L. and S.W. Melsted. 1955. The chemistry of zinc added to soils and clays. Soil Sci. Soc. Am. Proc. 19: 439-443.

Nychas, A. and V. Skarlou. 1983. Effect of $P$ and $Z$. maize grown on calcareous soils. J. Agric. Sci,, Camb. 100: $245-247$

Onki, K. 1977. Critical zinc levels related to early growth and development of determinate soybeans. Agron. J. 69: 969-974. Ohki, K. 1978. Zinc concentration in soybean as related to growth, photosynthesis and carbonic anhydrase activity. Crop Sci. 18: $79-82$

onki, K. 1984. Zinc nutrition related to critical deficiency and toxicity levels for sorghum. Agron. J. 76:253-256.

Ohki, K., O.E. Anderson and L.S. Jones. 1976. Residual Zn availability related to growth and nutrient gradients in corn. Agron. J. 68: 612-614.

OIsen, S.R. 1972. Micronutrient interactions. Pages 243-264. In J.J. Mortvedt, P.M. Giordano and W.L. Lindsay (eds.) Micronutrients in Agriculture. Soil Sci. Soc. Am., Madison, Wis.

Olsen, S.R., C.V. Cole, F.S. Watanabe and L.A. Dean. 1954. Estimation of available phosphorus in soils by extraction with sodi um bicarbonate. USDA Circ. 939.

Ozanne, P.G. 1980. Phosphate nutrition of plants--A general treatise. Pages 559-589. In F.E. Khasawneh, E.C. Sample and E.J. Kamprath (eds.) The Role of Phosphorus in Agriculture. Am. Soc. Agron., Madison, Wis. 
Pauli, A.N., R. Ellis, Jr. and H.C. Moser. 1968. Zinc uptake and translocation as influenced by phosphorus and calcium carbonate. Agron. J. $60: 394-395$.

Palusen, G.M. and O.A. Rotimi. 1968. Phosphorus-zinc interaction in two soybean varieties differing in sensitivity to phosphorus nutrition. Soil Sci. Soc. Am. Proc. 32:73-75.

Peck, T.R. and S.W. Melsted. 1967. Field sampling for soil testing. Pages 25-35. In Soil Testing and Plant Analysis. Part I. Soil Sci. Soc. Am., Madison, Wis.

Petersen, R.G. and L.D. Calvin. 1965. Sampling. Pages 54-72. In C.A. Black (ed.) Method of Soil Analysis, Part I. Agronomy No. 9, Am. Soc. Agron., Madison, Wis.

Phillips, J.M. and D.S. Hayman. 1970. Improved procedures for clearing roots and staining parasitic and vesicular-arbuscular mycorrhizal fungi for rapid assessment of infections. Trans. Br. Mycol. Soc. 55: 158-150.

Price, C.A. 1970. Molecular Approaches to Plant Physiology. MoGraw-Hill Book Co., New York. 398 p.

Price, C.A., H.E. Clark and E.A. Funkhouser. 1972. Functions of micronutrients in plants. Pages 231-242. In J.J. Mortvedt, P.M. Giordano and W.L. Lindsay (eds.) Micronutrients in Agriculture. Soil Sci. Soc. Am., Madison, Wis.

Quirk, J.P. and A.M. Posner. 1975. Trace element adsorption by soil minerals. Pages 95-107. In D.J.D. Nicholas and A.R. Egan (eds.) Trace Elements in Soil-Plant-Animal Systems. Academic Press, New York. 
Racz, G.J. and P.W. Haluschak. 1974. Effects of phosphorus concentration on $\mathrm{Cu}, \mathrm{Zn}, \mathrm{Fe}$ and Mn utilization by wheat. Can. J. Soil Sci. 54: $357-367$.

Radjagukguk, B., D.G. Edwards and L.C. Bell. 1980. Zine availability to young wheat plants in Darling Downs black earths. Aust. J. Agric. Res. 31: 1083-1096.

Randhawa, N.S. and F.E. Broadbent. 1965. Soil organic matter-metal complexes. 6. Stability constants of zinc-humic acid conplexes at different pH values. Soil Sci. 99:362-366.

Read, D.W.L., E.D. Spratt, L.D. Bailey, and F.G. Warder. 1977. Residual effects of phosphorus fertilizer. I. For wheat grown on four Chernozemic soil types in Saskatchewan and Manitoba. Can. J. Soil Sci. 57: 255-26்2.

Read, D.W.L., E.D. Spratt, L.D. Bailey, F.G. Warder and W.S. Ferguson. 1973. Residual value of phosphatic fertilizer on chernozemic soils. Can. J. Soil sci. 53: 389-398.

Reddy, M.R. and H.F. Perkins. 1974. Fixation of zinc by clay minerals. Soil Sci. Soc. Am. Proc. 38: 229-231.

Rhoden, E.G. and J.R. Alien. 1982. Effect of B, Mn and $\mathrm{Zn}$ on nodulation and $\mathrm{N}_{2}$ ixation in southern peas. Commun. Soil Sci. Plant Anal. 13:243-258.

Safaya, N.M. 1976. Phosphorus-zinc interaction in relation to absorption rates of phosphorus, zinc, copper, manganese, and iron in corn. Soil Sci. Soc. Am. J. 40:719-722.

Sal ami, U.A. and D.G. Kenefick. 1970. Stimulation of growth in zinc deficient corn seedlings by the addition of tryptophan. Crop Sci. 10:291-294. 
Schmid, W.E., H.P. Haag and E. Epstein. 1965. Absorption of zinc by excised barley roots. Physiol. Plant. 18:860-869.

Schnitzer, M. and S.I.M. Skinner. 1966. Organo-metallic interactions in soils. 5. Stability constants of $\mathrm{Cu}^{++}-, \mathrm{Fe}^{++}-$, and $\mathrm{Zn}^{++}-\mathrm{ful}^{\mathrm{i}} \mathrm{c}$ acid complexes. Soil Sci. 102: 361-365.

Schwartz, S.M., W.A. Norvell, E.E. Cary, D.L. Grunes, R.M. Nel ch, C.A. Sanchirico and M.D. Gilbert. 1985. Influence of scil temperature and $\mathrm{Zn}-\mathrm{P}$ interactions on uptake of nutrients and water by barley. Agron. Abstr., p. 184.

Sedberry, J.E., Jr. and C.N. Reddy. 1976. The distribution of zinc in selected soils in Louisiana. Commun. Soil Sci. Plant Anal. $7: 787-795$.

Seethambaram, Y. and V.S.R. Das. 1985. Photosynthesis and activities of $\mathrm{C}_{3}$ and $\mathrm{C}_{4}$ photosynthetic enzymes and zinc deficiency in Oryza sativa (L.) and Pennisetum americanum (L.) leeke. Phot os ynthetica. 19: 72-79.

Sharma, K.C., B.A. Krantz, A.L. Brown and J. Quirk. 1968. Interaction of $\mathrm{Zn}$ and $\mathrm{P}$ in top and root of corn and tomato. Agron. J. $60: 453-456$.

Sharpless, R.G., E.F. Wallihan and F.F. Peterson. 1969. Retention of zinc by some arid zone soil materials treated with zinc sulfate. Soil Sci. Soc. Am. Proc. 33: 901-904.

Shaw, E. and L.A. Dean. 1952. The use of dithizone as an extractant to estimate the zinc nutrient status of soils. Soil sei. 73: $341-347$

Shukla, U.C. and H.D. Morris. 1967. Rel ative efficiency of several zinc sources for corn (Zea mays L.). Agron. J. 59: 200-202. 
Shuman, L.M. 1975. The effect of soil properties on $2 n$ absorption by soils. Soil Sci. Soc. Am. Proc. 39:454-458.

Shiman, L.M. 976. Zinc adsorption isotherms for soil ciays with and without iron oxides removed. Soil Sci. Soc. Am. J. 40: $349-352$

Shuman, L.M. 1977. Adsorption of $\mathrm{Zn}$ by $\mathrm{Fe}$ and Al hydrous oxides as influenced by aging and pH: Soil sci. Soc. Am. J. 41: 703-706. Shuman, L.M. 1979. Zinc, manganese, and copper in soil fractions. Soil Sci. 127: 10-17.

Shuman, L.M. 1980. Zinc in soils. Pages 39-69. In J.0. Nriagu (ed.) Zinc in the environment. Part II. Ecological cycling. John Wiley \& Sons Inc., New York.

Shuman, L.M. 1985. Fractionation method for soil microelements. Soil Sci. 140:11-22.

Shuman, L.M. and W.L. Hargrove. 1985. Effect of tillage on the distribution of manganese, copper, iron and zinc in soil fractions. Soil Sci. Soc. Am. J. 49: 1117-1121.

Sillanpaa, M. 1982. Micronutrients and the micronutrient status of soils. A global study. Food and Agriculture organization of the United Nations, Rone, Bull. 48.

Sims, J.L. and W.H. Patrick, Jr. 1978. The distributon of micronutrient cations in soil under conditions of varying redox potential and pH. Soil Sci. Soc. Am. J. 42: 258-262.

Sims, J.T. 1986. Soil pH effects on the distribution and plant availability of manganese, copper and zinc. Soil Sci. Soc. Am. J. $50: 367-373$. 
Sokal, R.R. and F.J. Rohlf. 1969. Biometry: The Principles and Practice of statistics in Biological Research. W.H. Fireman and Co., San Francisco.

Soltanpour, P.N., A. Khan and W.L. Lindsay. 1976. Factors affecting DTPA-extractable Fe, $\mathrm{Zn}, \mathrm{Mn}$ and $\mathrm{Cu}$ from soils. Commun. Soil Sci. Plant Anal. 7: 797-821.

Soltanpour, P.N. and A.P. Schwab. 1977. A new soil test for simultaneous extraction of macro- and micronutrients in alkaline soils. Commun. Soil Sci. Plant Anal. 8: 195-207. Stanton, D.A. and R. Du T. Burger. 1967. Availability to plants of zinc sorbed by soil and hydrous iron oxides. Geoderma 1: $13-17$

Stanton, D.A. and R. Du T. Burger. 1970. Studies on zinc in selected Orange Free State soils: V. Mechanisms for reaction of zinc with iron and aluminum oxides. Agrochemophysica 2: 65-76. Stevenson, F.J. and M.S. Ardakani. 1972. Organic matter reactions involving micronutrients in soils. Pages 79-114. In J.J. Mortvedt, P.M. Giordano and W.L. Lindsay (eds.) Micronutrients in Agriculture. Soil Sci. Soc. Am., Madison, Wis.

Stewart, J.A. and K.C. Berger. 1965. Estimation of available zinc using magnesium chloride as extractant. Soil Sci. 100: $244-250$

Stewart, J.W.B. 1969. Micronutrients in Saskatchewan Soils. Report to the Meeting of Western Section of the National Soil Fertility Committee, February, Edmonton, Alberta. 
Stswart, J.W.B. and M. Tahir. 1971. Estimation of available zinc in prairie soils. Pages 983-991. In Proc. Int. Symp. Soil Fert. Evaluation, New Del hi, India.

Stout, W.L. and D.L. Bennett. 1983. Effect of Mg and $\mathrm{Zn}$ fertilization on soil test levels, ear leaf ocmposition and yields of corn in northern west Virginia. Commun. Soil Sci. Plant Anal. $14: 601-613$.

Stukenholtz, D.D., R.J. Olsen, G. Gogan and R.A. 0lson. 1966. on the mechanism of phosphorus-zinc interaction in corn nutrition. Soil Sci. Soc. Am. Proc. 30: 759-763.

Takaki, H. and M. Kushizaki. 1970. Accumulation of free tryptophan and tryptamine in zinc deficient maize seedlings. Plant and Cell Physiol. 11:793-804.

Tan, K.H., L.D. King and H.D. Morris. 1971. Complex reactions of zinc with organic matter extracted from sewage sludge. Soil Sci. Soc. Am. Proc. 35: 748-752.

Thomas, G.T. and A.T. Swoboda. 1963. Cation exchange in kaoliniteiron oxide systems. Clays Clay Miner. 11: 321-326.

Thomas, R.L., R.W. Sheard and J.R. Moyer. 1967. Comparison of conventional and automated procedures for $\mathrm{N}, \mathrm{P}$, and $\mathrm{K}$ analysis of plant material using a single digest. Agron. J. 59: $240-243$

Thorne, D.W. 1957. Zinc deficiency and its control. Adv. Agron. 9: $31-65$.

Tiessen, H., T.L. Roberts and J.W.B. Stewart. 1983. Carbonate analysis in soils and minerals by acid digestion and twoendpoint titration. Commun. Soil Sci. Plant Anal. 14: 161-166. 
Tiffin, L.0. 9972. Translocation of micronutrients in plants. Pages 199-229. In J.J. Mortvedt, P.M. Giordano and W.L. Lindsay (eds.) Micronutrients in Agriculture. Soil Sci. Soc. Am., Madison, wis.

Tiller, K.G., J.L. Honeysett and M.P.C. De Vries. 1972. Soil zinc and its uptake by plant. II. Soil chemistry in relation to prediction of availability. Aust. J. Soil Res. 10: 165-182.

Tiller, K.G. and J.G. Pickering. 1974. The synthesis of zinc silicates at $20^{\circ} \mathrm{C}$ and atmospheric pressure. Caays Clay Miner. $22: 409-416$.

Tinker, P.B. 1980. Role of rhizosphere microorganisms in phosphorus uptake by plants. Pages 617-653. In F.E. Khasawneh, E.C. Sample and E.J. Kamprath (eds.) The Role of Phosphorus in Agriculture. Am. Soc. Agron, Madison, Nis.

Tinker, P.B. and A. Gildon. 1983. Mycorrhizal $\mathrm{f} u n g i$ and $i$ on uptake. Pages 21-32. In D.A. Robb and W.S. Pierpoint (eds.) Metals and Micronutrients: Uptake and Utilization by Plants. Academic Press, New York.

Tisdale, S.L., W.L. Nelson and J.D. Beaton. 1985. Micronutrients and other beneficial elements in soils and fertilizers. Page 389. In Soil Fertility and Fertilizers. 4th edition. Macmillan Publishing Company, New York.

Tomasiewicz, D.J. and J.W.B. Stewart. 1982. Soil micronutrient problems and research in Western Canada. Pages 142-162. In Proceedings of the Soils and Crops Workshop, Extension Division, University of Saskatchewan, Saskatoon, Sask.

Trierweiler, J.F. and W.L. Lindsay. 1969. EDTA-ammoni um carbonate soil test for soil zinc. Soil sci. Soc. Am. Proc. 33: 49-54. 
Tlicker, T.C. and L.T. Kurtz. 1955. A comparison of severai chemical methods with the bioassay procedure for extracting zine from soil. Soil sei. Soc. Am. Proc. 19: 477-487.

Udo, E.T., H.L. Bohn and T.C. Tucker. 1970. Zinc adsorption by calcareous soils. Soil Sci. Soc. Am. Proc. 34: 405-407.

Ulrich, A. and F.J. Hills. 1973. Plant analysis as an aid in fertilizing sugar crops: Part I. Sugar beets. Pages 271-288. In L.M. Walsh and J.D. Beaton (eds.) Soil Testing and Plant Analysis. Soil Sci. Soc. Am., Madison, Wis.

Vallee, B.L. and W.E.C. Wacker. 1970. Metalloproteins. Page 192. In H. Neurath (ed.) The Proteins. 2nd edition. Academic Press, New York.

Viets, F.G., Jr. 1962. Chemistry and availability of micronutrients in soils. J. Agric. Food Chem. 10: 165-178.

Viets, F.G., Jr., L.C. Boawn and C.L. Crawford. 1954a. Zinc content - and deficiencies symptons of 26 crops grown on $2 n$ deficient soils. Soil sci. $78: 305-316$.

Viets, F.G., Jr., L.C. Boawn and C.L. Crawf ord. 1954b. Zinc content of bean plants in relation to deficiency symptoms and yield. Plant Physiol. 29: 76-79.

Viro, P.J. 1955. Use of ethylene diamine tetra acetic acid in soil anal ysis: 1. Soil Sci. 79:459-465.

Wagar, B.I., J.W.B. Stewart and J.L. Henry. 1986. Comparison of single 1 arge broadcast and small annual seed-placed phosphorus treatments on yield and phosphorus and zinc contents of wheat on Chernozemic soils. Can. J. Soil Sci. 66:237-248. 
iarnock, R.E. 1970. Micronutrient uptake and mobility within corn plants (Zea mays L.) in relation to phosphorus-induced zinc deficiency. Soil Sci. Soc. Am. Proc. 34: 765-769.

Watanabe, F.S., W.L. Lindsay and S.R. Olsen. 1965. Nutrient balance involving phosphorus, iron and zinc. Soil Sci. Soc. Am. Proc. 29: $562-565$

Wear, J.I. and C.E. Evans. 1968. Relationship of zinc uptake by corn and sorghum to soil zinc measured by three extractants. Soil Sci. Soc. Am. Proc. $32: 543-546$.

White, M.L. 1957. The occurrence of zinc in soil. Econ. Geol, 52: 645-651. Wilkinson, H.F., J.F. Loneragan and J.P. Quirk. 1968. The movement of zinc to plant roots. Soil sci. Soc. Am. Proc. 32: 831-833.

Woodbridge, C.G. 1954. Zinc deficiency in fruit trees in Okanagan Valley in British Columbia. Can. J. Ag. Sci. 34:545-551.

Yadav, O.P. and U.C. Shukla. 1982. Effect of applied phosphorus and zinc on their absorption and distribution in chickpea plant. Soil Sci. 134: $239-243$.

Youngdahl, L.J., L.V. Suec, W.C. Liebhardt and M.R. Teel. 1977. Changes in the zinc-65 distribution in corn root tissue with a phosphorus variable. Crop. Sci. 17:66-69.

Zunino, H., M. Aguilera, M. Caiozzi, P. Peirano, F. Borie and J.P. Martin. 1979. Metal-binding organic macromolecules in soil: 3. Competition of $\mathrm{Mg}$ (II) and $\mathrm{Zn}$ (II) for binding sites in humic and $\mathrm{f}$ ul vic-type model polymers. Soil Sci. 128: 257-266.

Zunino, H. and J.P. Martin. 1977. Metal-binding organic macromol ecules in soil: 1. Hypothesis interpreting the role of soil organic matter in the translocation of metal ions from rocks to biological systems. Soil Sci. 123: $65-76$. 
A P P E N D I X

$-$ 
Table A. 1 Mean squares from the analysis of variance for the yield of beans grown on Sutherland soil.

Source df $\frac{1 / 10 \text { bloom stage }}{\text { Roots Tops }}$ Roots Seeds Straw

$\begin{array}{lllllll}\text { P Iinear (P-L) } & 1 & 0.28^{\text {P erfects }} & 10.77^{* *} & 1.31^{* *} & 53.32^{* *} & 34.89^{* *} \\ \text { P quadratic }(P-Q) & 1 & 0.45^{* *} & 6.30^{* *} & 0.78^{* *} & 50.54^{* *} & 30.27^{* *} \\ \text { P cubic }(P-C) & 1 & 0.06 & 1.71^{*} & 0.23^{*} & 12.26^{* *} & 5.72^{* *}\end{array}$

\begin{tabular}{|c|c|c|c|c|c|c|}
\hline \multicolumn{7}{|c|}{ Zn epfects } \\
\hline Zn I inear $(Z n-L)$ & 1 & 0.01 & $3.99^{* *}$ & 0.02 & $6.85^{* *}$ & $5.70^{* *}$ \\
\hline Zn quadratic $(\mathrm{Zn}-\mathrm{Q})$ & 1 & 0.00 & $1.33^{* *}$ & 0.00 & $3.01^{* *}$ & $3.26^{* *}$ \\
\hline
\end{tabular}

$$
\begin{array}{llll}
P-L & \times & Z n-L \\
P-L & \times & Z n-Q \\
P-Q & \times & Z n-L \\
P-Q & \times & Z n-Q \\
P-C & \times & Z n-L \\
P-C & Z & Z n-Q
\end{array}
$$

Error

\begin{tabular}{llllll}
\multicolumn{7}{c}{$\begin{array}{l}\text { Interaction effects } \\
1\end{array}$} & 0.01 & $1.99^{* *}$ & 0.00 & $1.58^{*}$ & 0.54 \\
1 & 0.01 & 0.48 & 0.00 & 1.29 & $2.15^{*}$ \\
1 & 0.00 & $0.69^{*}$ & 0.00 & $1.44^{*}$ & 1.49 \\
1 & 0.00 & 0.07 & 0.01 & 0.03 & 0.01 \\
1 & 0.00 & 0.01 & 0.01 & 0.37 & 0.23 \\
1 & 0.00 & 0.00 & 0.03 & 0.37 & 0.00 \\
36 & 0.02 & 0.15 & 0.04 & 0.35 & 0.40 \\
& & & & & \\
\hline
\end{tabular}

${ }^{*}{ }^{* *}$ Indi cate 0.05 and 0.01 significance levels, respectively. 
Tanle A.2 Mean squares from the analysis of variance for the yield of beans grown on Carrot River soil.

\begin{tabular}{|c|c|c|c|c|c|c|}
\hline \multirow{2}{*}{ Source } & \multirow{2}{*}{$d f$} & \multicolumn{2}{|c|}{$1 / 10$ bloom stage } & \multicolumn{3}{|c|}{ Maturity } \\
\hline & & Roots & Tops & Roots & Seeds & Straw \\
\hline \multicolumn{7}{|c|}{$P$ effects } \\
\hline$P$ linear $(P-L)$ & 1 & $0.23^{\bar{*}}$ & $2.97^{* *}$ & $0.38^{*}$ & $29.35^{* *}$ & $11.22^{* *}$ \\
\hline P quadratic $(P-Q)$ & $?$ & $0.17^{* *}$ & $2 \cdot 38^{* *}$ & $0.30^{*}$ & $29.86^{* *}$ & $7.81^{* *}$ \\
\hline$P$ cubic $(P-C)$ & 1 & 0.05 & $0.47^{*}$ & 0.03 & $5.76^{* *}$ & 1.72 \\
\hline
\end{tabular}

\section{$\mathrm{Zn}$ effects}

0 vs. $5(\mathrm{Zn})$

$0.03 \quad 3.85^{* *} \quad 0.00 \quad 14.99^{* *} 5.53^{* *}$

\section{Interaction effects}

\begin{tabular}{|c|c|c|c|c|c|c|c|}
\hline $\mathrm{P}-\mathrm{L} \times \mathrm{Zn}$ & 1 & 0.03 & $0.53^{*}$ & 0.01 & $3.83 *$ & & 0.85 \\
\hline$P-Q \times Z n$ & 1 & 0.07 & 0.04 & 0.02 & 1.76 & & 0.10 \\
\hline $\mathrm{P}-\mathrm{C} \times \mathrm{Zn}$ & 1 & 0.02 & 0.00 & 0.00 & 0.07 & - & 0.04 \\
\hline Error & 24 & 0.02 & 0.09 & 0.05 & 0.48 & & 0.61 \\
\hline
\end{tabular}

* ${ }^{* *}$ Indicate 0.05 and 0.01 si gnificance levels, respectively. 
$I z t=$ A. 3 Mean squares from the analysis of variance for the yield of beans grown on Meota soil.

\begin{tabular}{|c|c|c|c|c|c|c|}
\hline \multirow{2}{*}{ Source } & \multirow{2}{*}{$d f$} & \multicolumn{2}{|c|}{$1 / 10$ bloom stage } & \multicolumn{3}{|c|}{ Maturity } \\
\hline & & Roots & Tops & Roots & Seeds & Straw \\
\hline \multicolumn{7}{|c|}{$\underline{P \text { effects }}$} \\
\hline$P$ linear $(P-L)$ & 1 & $0.26^{* *}$ & $3.94^{* *}$ & $0.34^{* *}$ & $11.95^{* *}$ & $10.34^{* *}$ \\
\hline$P$ quadratic $(P-Q)$ & 1 & $0.12^{*}$ & 0.46 & $0.51^{* *}$ & $16.44^{* *}$ & $7.54^{* *}$ \\
\hline$P$ cubic $(P-C)$ & 1 & 0.02 & 0.55 & 0.10 & 1.75 & 0.17 \\
\hline
\end{tabular}

Zn effects
0 vs. $5(\mathrm{Zn})$
10.01
0.10
0.02
0.03
0.55

\section{Interaction effects}

\begin{tabular}{lcccccc}
$P-L \times$ Zn & 1 & 0.05 & 0.13 & 0.01 & 0.00 & 0.01 \\
$P-Q \times$ Zn & 1 & 0.01 & 0.11 & 0.00 & 0.00 & 0.12 \\
$P-C \times$ Zn & 1 & 0.00 & 0.02 & 0.00 & 0.23 & 0.04 \\
Error & 24 & 0.02 & 0.13 & 0.04 & 1.05 & 0.78 \\
\hline
\end{tabular}

* ** Indi cate 0.05 and 0.01 significance levels, respectively. 
$T \because 21$ A. 4 Mean squares from the analysis of variance for the $2 n$ concentration of beans grown on Sutherland soil.

Source df $\frac{1 / 10 \text { bioom stage }}{\text { Roots Tops }}$ Roots Seeds Straw

$\begin{array}{llrlrrr}\text { P linear (P-L) } & 1 & 80.23^{* *} & 816.63^{* *} & 44.25^{* *} & 369.75^{* *} & 469.69^{* *} \\ \text { P quadratic (P-Q) } & 1 & 160.33^{* *} & 555.39^{* *} & 66.24^{* *} & 1021.58^{* *} & 423.63^{* *} \\ \text { P cubic }(P-C) & 1 & 53.49^{* *} & 110.37^{* *} & 16.14 & 161.84^{* *} & 142.83^{*}\end{array}$

\begin{tabular}{|c|c|c|c|c|c|c|}
\hline \multicolumn{7}{|c|}{$\mathrm{Zn}$ effects } \\
\hline $2 n 1$ inear $(2 n-L)$ & 1 & $485.10^{* *}$ & $1954.69^{* *}$ & $741.20^{* *}$ & $660.66^{*}$ & $667.95^{* *}$ \\
\hline Zn quadratic $(Z n-Q)$ & 1 & 20.41 & $150.25^{* *}$ & 8.25 & 5.51 & 25.0 \\
\hline
\end{tabular}

P-L $\times 2 n-L$

$P-L \quad X \quad Z n-Q$

$\mathrm{P}-\mathrm{Q} \times 2 \mathrm{n}-\mathrm{L}$

$\mathrm{P}-\mathrm{Q} \times \mathrm{Zn}-\mathrm{Q}$

P-C $\times \mathrm{Zn}-\mathrm{L}$

$P-C \quad Z \quad Z n-Q$

Error

\begin{tabular}{cccccc}
\multicolumn{5}{c}{ Interaction effects } \\
1 & $683.55^{* *}$ & 22.60 & $75.99^{* *}$ & $60.82^{*}$ & 7.86 \\
1 & 0.09 & 10.55 & 9.38 & 6.26 & 0.45 \\
1 & $322.63^{* *}$ & $101.95^{* *}$ & $60.03^{* *}$ & $139.32^{* *}$ & $47.07^{*}$ \\
1 & 8.11 & 25.43 & 10.32 & 0.03 & 6.55 \\
1 & 18.74 & 3.49 & $33.66^{* *}$ & $74.18^{*}$ & $39.65^{*}$ \\
1 & 0.02 & 14.43 & 8.12 & 0.85 & 13.39 \\
36 & 6.89 & 11.15 & 4.38 & 12.22 & 17.48 \\
& & & & &
\end{tabular}

* ${ }^{* *}$ Indi cate 0.05 and 0.01 significance levels, respectively. 
Tati: A.5 Mean squares from the analysis of variance for the $2 n$ concentration of beans grown on Carrot kiver soil.

Source df $\frac{1 / 10 \text { bloom stage }}{\text { Roots Tops }}$ Roots Seeds Straw

\section{$P$ effects}

$\begin{array}{lllllll}P \text { Iinear (P-L) } & 1 & 12.15 & 311.65^{* *} & 5.15 & 53.73^{*} & 174.35^{* *} \\ \text { P quadratic (P-Q) } & 1 & 16.76 & 141.75^{*} & 37.56^{*} & 118.76^{* *} & 88.71^{* *} \\ \text { P cubic (P-C) } & 1 & 90.95^{* *} & 23.12^{*} & 55.09^{* *} & 14.43 & 7.75\end{array}$

0 vs. $5($ in $)$

$$
15428.01^{\frac{\text { Zn effects }}{* *} 2467.53^{* *}} 2187.90^{* *} 260.49^{* *} 1575.01^{* *}
$$

\section{Interaction effects}

\begin{tabular}{lcccccc}
$\mathrm{P}-\mathrm{L} X \mathrm{Zn}$ & 1 & $243.54^{* *}$ & 0.32 & $139.70^{* *}$ & 1.67 & 1.90 \\
$\mathrm{P}-\mathrm{Q} \times \mathrm{Zn}$ & 1 & 20.22 & $26.09^{*}$ & $63.96^{* *}$ & 4.15 & 1.04 \\
$\mathrm{P}-\mathrm{C} \times \mathrm{Zn}$ & 1 & 33.93 & 4.16 & 24.25 & 0.40 & 1.69 \\
Error & 24 & 12.45 & 5.30 & 6.93 & 8.28 & 7.09 \\
\hline
\end{tabular}

* ** Indicate 0.05 and 0.01 significance levels, respectively. 
$\therefore 01:$ A.6 Mean squares from the analysis of variance for the $\mathrm{Zn}$ concentration beans grown on Meota soil.

Source df $\frac{1 / 10 \text { bloom stage }}{\text { Roots Tops }}$ Roots Seeds Straw

\begin{tabular}{|c|c|c|c|c|c|c|}
\hline \multicolumn{7}{|c|}{ P effects } \\
\hline$P$ linear $(P-L)$ & 1 & 1.06 & 1.98 & 1.24 & 13.51 & $44.28^{* *}$ \\
\hline$P$ quadratic $(P-Q)$ & 1 & 10.68 & $22.85^{*}$ & 33.94 & $135.05^{* *}$ & $62 \cdot 10^{* *}$ \\
\hline$P$ cubic $(P-C)$ & 1 & 0.02 & 0.74 & 1.44 & 0.48 & 8.56 \\
\hline
\end{tabular}

0 vs. $5(\mathrm{Zn})$

$\frac{\text { Zn effects }}{\frac{x^{* *}}{501.65^{* *}} 685.13^{* *} 60.50^{*} 65.84^{* *}}$

Interaction epfects

\begin{tabular}{lrrrrrr}
$P-L \times Z n$ & 1 & 9.36 & 0.02 & 1.59 & 19.03 & 9.79 \\
$P-Q \times$ Zn & 1 & 0.94 & 16.05 & 6.20 & 8.43 & 15.37 \\
$P-C \times$ Zn & 1 & 10.85 & 1.38 & 1.14 & 7.10 & 1.80 \\
Error & 24 & 50.48 & 5.22 & 6.57 & 8.99 & 4.77 \\
\hline
\end{tabular}

* ${ }^{* *}$ Indicate 0.05 and 0.01 si gnificance levels, respectively. 
Tar. $\therefore .7$ Mean squares from the analysis of variance for the zn uptake beans grown on Sutherland soil.

Source df $\frac{1 / 10 \text { bloom stage }}{\text { Roots Tops }}$ Roots Seeds Straw

\begin{tabular}{|c|c|c|c|c|c|c|}
\hline \multicolumn{7}{|c|}{$P$ effects } \\
\hline$P$ linear $(P-L)$ & 1 & $139.25^{* \bar{*}}$ & $\overline{1669.20}{ }^{* *}$ & $551.40^{* *}$ & $20571.46^{* *}$ & $2478.09^{* *}$ \\
\hline quadratic $(P-Q)$ & 1 & $177.16^{* *}$ & $819.72^{* *}$ & $246.02^{* *}$ & $13311.21^{* *}$ & $1776.94^{*}$ \\
\hline cubic $(P-C)$ & 1 & 11.94 & 298.98 & $85.28^{*}$ & $5064.13^{* *}$ & 42.36 \\
\hline
\end{tabular}

\begin{tabular}{|c|c|c|c|c|c|c|}
\hline \multicolumn{7}{|c|}{ Zn effects } \\
\hline $\mathrm{Zn} I$ inear $(\mathrm{Zn}-\mathrm{L})$ & 1 & $104.19^{*}$ & $15344.02^{* *}$ & $313.02^{* *}$ & $19130.17^{* *}$ & $16894.44^{* *}$ \\
\hline Zn quadratic $(Z n-Q)$ & 1 & 2.53 & $1763.71^{* *}$ & 3.05 & 848.65 & $1464.45^{*}$ \\
\hline
\end{tabular}

\section{Interaction effects}

$\begin{array}{lrrrrrr}\text { P-L } \times \text { Zn-L } & 1 & 41.39 & 1832.65^{* *} & 0.36 & 2261.69^{*} & 2107.91^{* *} \\ \text { P-L } \times \text { Zn-Q } & 1 & 6.85 & 63.77 & 9.87 & 974.72 & 946.91 \\ \text { P-Q } \times \text { Zn-L } & 1 & 15.59 & 266.90 & 13.79 & 527.43 & 165.42 \\ \text { P-Q } \times \text { Zn-Q } & 1 & 0.39 & 6.70 & 16.14 & 9.62 & 24.64 \\ \text { P-C } \times \text { Zn-L } & 1 & 0.14 & 66.37 & 0.10 & 0.42 & 80.92 \\ \text { P-C Z Zn-Q } & 1 & 0.08 & 23.34 & 1.01 & 49.95 & 170.17 \\ \text { Error } & 36 & 14.84 & 98.66 & 19.71 & 423.49 & 250.61\end{array}$

* ${ }^{* *}$ Indicate 0.05 and 0.01 si gnificance 1 evels, respectively. 


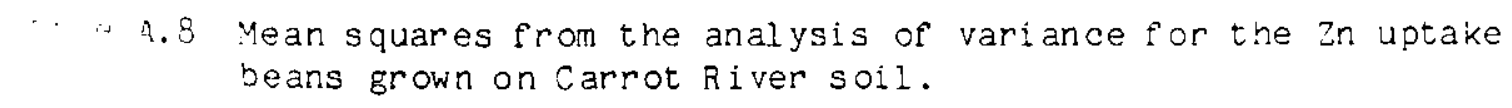

Sout.. df $\quad$ df $\frac{1 / 10 \text { bloom stage }}{\text { Roots Tops }}$

\begin{tabular}{|c|c|c|c|c|c|c|}
\hline \multicolumn{7}{|c|}{$\underline{P \text { effects }}$} \\
\hline$P$ linear $(P-L)$ & 1 & $367.97^{* *}$ & 87.64 & $536.19^{* *}$ & $24368.37^{* *}$ & 670.61 \\
\hline$P$ quadratic $(P-Q)$ & 1 & $80.53^{*}$ & 213.97 & 113.25 & $17812.89^{* *}$ & $861.17^{*}$ \\
\hline$P$ cubic $(P-C)$ & 1 & 0.00 & 40.97 & 17.77 & $3897.70^{*}$ & 470.05 \\
\hline
\end{tabular}

0 vs. $5(\mathrm{Zn})$

$12693.61^{* *} 28285.12^{* *} 2665.40^{* *} 32242.13^{* *} 47097.64^{* *}$

Interaction effects

\begin{tabular}{|c|c|c|c|c|c|c|}
\hline $\mathrm{P}-\mathrm{L} \times \mathrm{Zn}$ & 1 & 57.73 & $780.26^{* *}$ & 18.25 & $6001.54^{*}$ & $1939.60^{* *}$ \\
\hline$P-Q \times Z n$ & 1 & 4.37 & 19.42 & 20.19 & 1640.70 & 457.02 \\
\hline$P-C \times Z n$ & 1 & 33.08 & 1.70 & 25.86 & 13.58 & 42.60 \\
\hline Error & 24 & 17.85 & 99.37 & 64.11 & 787.15 & 178.56 \\
\hline
\end{tabular}

* ${ }^{* *}$ Indicate 0.05 and 0.01 significance levels, respectively. 
Fo. 4.9 Mean squares from the analysis of variance for the $\mathrm{Zn}$ uptake beans grown on Meota soil.

\begin{tabular}{|c|c|c|c|c|c|c|}
\hline \multirow{2}{*}{ Soln is } & \multirow{2}{*}{$d f$} & \multicolumn{2}{|c|}{$1 / 10$ bloom stage } & \multicolumn{3}{|c|}{ Maturity } \\
\hline & & Roots & Tops & Roots & Seeds & Straw \\
\hline \multicolumn{7}{|c|}{$P$ effects } \\
\hline$P$ linear $(P-L)$ & 1 & $404.41^{*}$ & $2455.59^{* *}$ & $246.98^{* *}$ & $2742.22^{*}$ & 30.38 \\
\hline$P$ quadratic $(P-Q)$ & 1 & 81.58 & 52.33 & 103.37 & 24.12 & 387.06 \\
\hline$P$ cubic $(P-C)$ & 1 & 43.60 & 141.68 & 48.64 & 1059.61 & 173.33 \\
\hline
\end{tabular}

0 vs. $5(\mathrm{Zn})$

$\frac{\mathrm{Zn} \text { effects }}{\text { * }^{*}+445.54^{*}}$

$11639.24^{* *} 4445.54^{* *} 2717.54^{* *} 2917.91^{*} 4049.32^{* *}$

Interaction effects

\begin{tabular}{lrrrrrr}
$\mathrm{P}-\mathrm{L} X \mathrm{Zn}$ & 1 & 212.38 & 144.35 & 62.66 & 825.99 & 479.26 \\
$\mathrm{P}-\mathrm{Q} X \mathrm{Zn}$ & 1 & 17.49 & 10.56 & 0.69 & 88.51 & $810.05^{*}$ \\
$\mathrm{P}-\mathrm{C} \times \mathrm{Zn}$ & 1 & 22.88 & 3.06 & 1.65 & 71.60 & 16.35 \\
Error & 24 & 84.68 & 144.08 & 34.81 & 611.66 & 121.76 \\
\hline
\end{tabular}

* ${ }^{* *}$ Indi cate 0.05 and 0.01 significance $I$ evels, respecti vely. 
ible A.:O Mean squares from the analysis of variance for the $P$ concentration of beans grown on Sutherland soil.

Sol de $\quad$ de $\frac{1 / 10 \text { bloom stage }}{\text { Roots Tops }}$

\begin{tabular}{|c|c|c|c|c|c|c|}
\hline \multicolumn{7}{|c|}{$\mathrm{P}$ effects } \\
\hline$P$ Iinear $(P-L)$ & 1 & $3.65^{* *}$ & $103.21 * *$ & $12.74^{* *}$ & $2.23^{* *}$ & $21.08^{* *}$ \\
\hline$P$ quadratic $(P-Q)$ & 1 & $0.53^{* *}$ & $1.19^{* *}$ & 0.01 & 0.00 & 3.25 \\
\hline$P$ cubic $(P-C)$ & 1 & $0.21^{* *}$ & $1.85^{* *}$ & 0.05 & 0.06 & 0.10 \\
\hline
\end{tabular}

\begin{tabular}{|c|c|c|c|c|c|c|}
\hline & & $\underline{\mathrm{Zn}}$ & pects & & & \\
\hline Zn linear $(Z n-L)$ & 1 & $0.42^{\bar{*}}$ & $30.77^{* *}$ & $0.28^{* *}$ & $17.89^{* *}$ & 5.13 \\
\hline Zn quadratic $(Z n-Q)$ & 1 & 0.00 & $7.89^{* *}$ & $0.14^{*}$ & $5.37^{* *}$ & 2.00 \\
\hline
\end{tabular}

\section{Interaction effects}

$\begin{array}{lllllll}P-L \times Z n-L & 1 & 0.09^{* *} & 19.03^{* *} & 0.10 & 2.46^{* *} & 2.08^{* *} \\ P-L \times Z n-Q & 1 & 0.01 & 3.06^{* *} & 0.09 & 1.07^{*} & 0.88^{* *} \\ P-Q \times Z n-L & 1 & 0.03 & 1.31^{* *} & 0.01 & 2.06^{* *} & 0.14 \\ P-Q \times Z n-Q & 1 & 0.01 & 0.47 & 0.00 & 0.78^{*} & 0.08 \\ P-C \times Z n-L & 1 & 0.02 & 1.05^{* *} & 0.00 & 0.88^{*} & 0.03 \\ P-C & 1 & 0.01 & 0.00 & 0.00 & 0.04 & 0.02 \\ \text { Error } & 36 & 0.01 & 0.12 & 0.03 & 0.17 & 0.06\end{array}$

* ${ }^{* *}$ Indicate 0.05 and 0.01 significance 1 eveis, respectively. 
Htile A.11 Yean squares from the analysis of variance for $P$ concentration of beans grown on Carrot River soil.

df $\frac{1 / 10 \text { bloom stage }}{\text { Roots Tops Roots Seeds Straw }}$

\begin{tabular}{|c|c|c|c|c|c|c|}
\hline \multirow[b]{2}{*}{$P$ Iinear $(P-L)$} & \multicolumn{3}{|c|}{$P$ effects } & & & \\
\hline & 1 & $22.68^{* *}$ & $85.01 * *$ & $32 \cdot 36^{* *}$ & $9.71^{* *}$ & $11.23^{* *}$ \\
\hline$P$ quadratic $(P-Q)$ & 1 & $1.04^{* *}$ & $3.67^{* *}$ & $3.52^{* *}$ & 0.32 & $0.67^{*}$ \\
\hline$P$ cubic $(P-C)$ & 1 & $0.09^{* *}$ & 0.11 & $0.45^{* *}$ & 0.20 & 0.02 \\
\hline
\end{tabular}

ovs. $5(\mathrm{Zn}) \quad 1 \quad 0.2^{\frac{\text { Zn erfects }}{* *} 22.92^{*}} \quad 0.65^{* *} 31.01^{* *} 8.02^{* *}$

\begin{tabular}{lcccccc}
$P-L \times Z n$ & 1 & $0.28^{* *}$ & $8.50^{* *}$ & 0.01 & $7.80^{* *}$ & $0.91^{*}$ \\
$P-Q \times$ Zn & 1 & 0.03 & 0.14 & 0.14 & $1.39^{*}$ & $1.08^{*}$ \\
$P-C \times$ Zn & 1 & 0.01 & 0.19 & 0.02 & 0.01 & 0.29 \\
Error & 24 & 0.02 & 0.19 & 0.04 & 0.25 & 0.15 \\
\hline
\end{tabular}

* ${ }^{* *}$ Indicate 0.05 and 0.01 significance 1 evels, respectively. 
2ble A.12 Mean squares from the analysis of variance for the $P$ concentration of beans grown on Meota soil.

df $\frac{1 / 10 \text { bloom stage }}{\text { Roots Tops }}$ Roots Seeds Straw

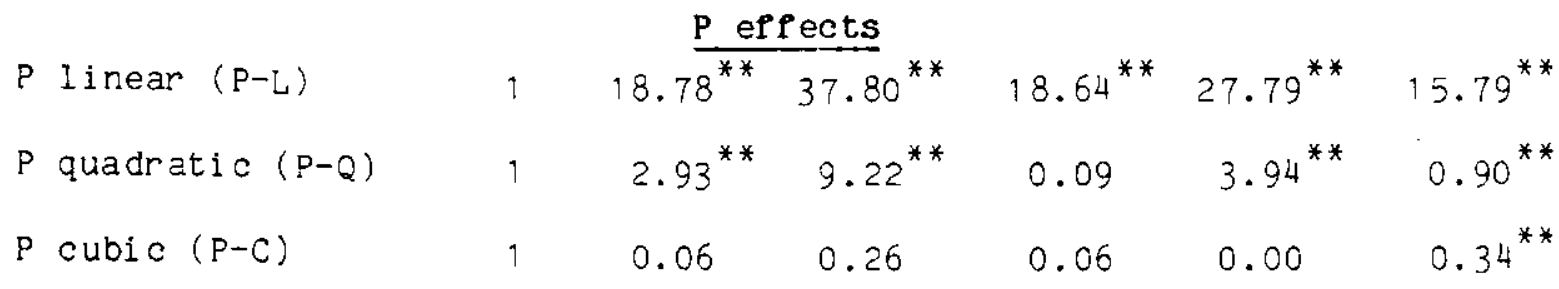

\section{Zn efrects}
0 vs. $5(\mathrm{zn})$
$10.06 \quad 1.07^{*}$
0.05
$0.30^{*}$
$0.19^{*}$

\section{Interaction effects}

$\begin{array}{lcccccc}\text { P-L X Zn } & 1 & 0.43 & 0.16 & 0.00 & 0.01 & 0.03 \\ P-Q \times \text { Zn } & 1 & 0.10 & 0.10 & 0.00 & 0.05 & 0.00 \\ \text { P-C X Zn } & 1 & 0.13 & 0.05 & 0.00 & 0.00 & 0.01 \\ \text { Error } & 24 & 0.15 & 0.14 & 0.10 & 0.05 & 0.04\end{array}$

${ }^{*}$, ${ }^{*}$ Indi cate 0.05 and 0.01 significance levels, respectively. 
able A.13 Mean squares from the analysis of variance for the Puptake of beans grown on Sutherland soil.

SW: ce df $\frac{1 / 10 \text { bioon stage }}{\text { Roots Tops }}$ Roots Seeds Straw

\begin{tabular}{|c|c|c|c|c|c|c|}
\hline \multicolumn{7}{|c|}{$\mathrm{P}$ effects } \\
\hline$P$ linear $(P-L)$ & 1 & $2.38^{\bar{*}}$ & $951.63^{* *}$ & $24.38^{* *}$ & $1323.30^{* *}$ & $720.62^{* *}$ \\
\hline$P$ quadratic $(P-Q)$ & 1 & $1.111^{* *}$ & $36.67^{* *}$ & 0.43 & $814.00^{* *}$ & $191.28^{* *}$ \\
\hline$P$ cubic $(P-C)$ & 1 & $0.22^{*}$ & 0.16 & 0.09 & $156.72^{* *}$ & 0.07 \\
\hline
\end{tabular}

\begin{tabular}{|c|c|c|c|c|c|c|}
\hline inear $(Z n-L)$ & & $\pi^{*}$ & . $*$ & & 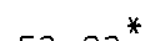 & $0^{*}$ \\
\hline Zn quadratic $(7 n-0)$ & 1 & 0 & & & & \\
\hline
\end{tabular}

\section{Interaction effects}

$\begin{array}{lllllll}\mathrm{P}-\mathrm{L} \times \mathrm{Zn}-\mathrm{L} & 1 & 0.13 & 5.73 & 0.20 & 0.67 & 13.88^{*} \\ \mathrm{P}-\mathrm{L} \times \mathrm{Zn}-\mathrm{Q} & 1 & 0.01 & 0.06 & 0.11 & 0.44 & 0.42 \\ \mathrm{P}-\mathrm{Q} \times \mathrm{Zn}-\mathrm{L} & 1 & 0.00 & 0.40 & 0.02 & 4.96 & 0.23 \\ \mathrm{P}-\mathrm{Q} \times \mathrm{Zn}-\mathrm{Q} & 1 & 0.02 & 1.24 & 0.02 & 12.18 & 1.06 \\ \mathrm{P}-\mathrm{C} \times \mathrm{Zn}-\mathrm{L} & 1 & 0.00 & 1.31 & 0.03 & 4.02 & 0.22 \\ \mathrm{P}-\mathrm{C} Z \mathrm{Zn}-\mathrm{Q} & 1 & 0.01 & 0.56 & 0.07 & 2.73 & 0.45 \\ \text { Error } & 36 & 0.05 & 2.02 & 0.31 & 9.82 & 3.03\end{array}$

* ${ }^{* *}$ Indi cate 0.05 and 0.01 significance $l$ evels, respectively. 
ble A.14 Mean squares from the analysis of variance for the P uptake of beans grown on Carrot River soil.

S.... $\quad$ df $\frac{1 / 10 \text { bloom stage }}{\text { Roots Tops Raturity }}$

\begin{tabular}{|c|c|c|c|c|c|c|}
\hline \multicolumn{7}{|c|}{ P effects } \\
\hline$P$ Iinear $(P-L)$ & 1 & 16.27 & $790.47^{* *}$ & $61 \cdot 38^{* *}$ & $1087.97^{* *}$ & $547.07^{* *}$ \\
\hline P quadratic $(P-Q)$ & 1 & 0.05 & $65.71^{* *}$ & $10.44^{* *}$ & $531.27^{* *}$ & $78.28^{* *}$ \\
\hline$P$ cubic $(P-C)$ & 1 & $0.27^{* *}$ & 5.02 & 0.75 & $59.30^{*}$ & 3.61 \\
\hline \multicolumn{7}{|c|}{$\mathrm{Zn}$ effects } \\
\hline 0 vs. $5(Z n)$ & 1 & $0.75^{* *}$ & $11.59^{*}$ & 1.24 & $63.25^{*}$ & $39.81^{*}$ \\
\hline \multicolumn{7}{|c|}{ Interaction effects } \\
\hline$P-L \times Z n$ & 1 & $0.19^{* *}$ & 3.58 & 0.23 & 12.30 & 0.31 \\
\hline$P-Q \times Z n$ & 1 & 0.40 & 0.82 & 0.04 & $2 .: 4$ & 15.81 \\
\hline $\mathrm{P}-\mathrm{C} \times \mathrm{Zn}$ & 1 & 0.01 & 0.02 & 0.07 & 2.11 & 6.28 \\
\hline Error & 24 & 0.02 & 2.22 & 0.43 & 13.87 & 9.26 \\
\hline
\end{tabular}

* ** Indi cate 0.05 and 0.01 si gnificance 1 evels, respectively. 
'able A.15 Mean squares from the analysis of variance for the P uptake of beans grown on Meota soil.

$\therefore \quad$ df $\frac{1 / 10 \text { bloom stage }}{\text { Roots Tops }}$ Roots Seeds Straw

\begin{tabular}{|c|c|c|c|c|c|c|}
\hline \multicolumn{7}{|c|}{$P$ effects } \\
\hline$P$ Iinear $(P-L)$ & 1 & $14.66^{* *}$ & $542.34^{* *}$ & $84.25^{* *}$ & $2696.66^{* *}$ & $1127.73^{*}$ \\
\hline$P$ quadratic $(P-Q)$ & 1 & $2.22^{* *}$ & $92.24^{* *}$ & 0.27 & $811.04^{* *}$ & 10.29 \\
\hline$P$ cubic $(P-C)$ & 1 & 0.11 & $11.77^{*}$ & 0.01 & 9.71 & 16.04 \\
\hline
\end{tabular}

0 vs. $5(\mathrm{Zn})$

1

Zn effects

$\begin{array}{lllll}0.26 \quad 5.89 & 0.47 & 14.11 & 3.04\end{array}$

P-L X Zn

Interaction effects

$8-Q x \geq n$

0.04

2.15

0.11

0.18

1.10

$P-Q \times Z n$

0.01

0.70

0.00

1.66

0.01

$\mathrm{P}-\mathrm{C} \times \mathrm{Zn}$

0.10

0.17

0.00

5.63

0.01

Error

24

0.25

1.84

0.96

18.73

4.11

* ** Indicate 0.05 and 0.01 significance levels, respectively. 
$4 ! 1: 4.16$ Mean squares from the analysis of variance for the in derived from fertilizer ( $\%$ zndf $f$ ) by beans grown on the Sutherland soil.

Sow: df $\frac{1 / 10 \text { bloom stage }}{\text { Roots Tops }}$ Roots Seeds Straw

\begin{tabular}{|c|c|c|c|c|c|c|}
\hline \multicolumn{7}{|c|}{ P effects } \\
\hline$P$ linear $(P-L)$ & 1 & $116 . \overline{85^{*}}$ & $137.56^{*}$ & 39.96 & $605.07^{* *}$ & $575.71^{* *}$ \\
\hline$P$ quadratic $(P-Q)$ & 1 & 26.18 & 36.50 & 23.45 & $172.42^{*}$ & $201 \cdot 37^{*}$ \\
\hline$P$ cubic $(P-C)$ & 1 & 0.46 & 0.37 & 0.36 & 1.52 & 4.77 \\
\hline
\end{tabular}

5 vs. $10(\mathrm{Zn})$

$1 \quad \frac{\text { Zn effects }}{20^{* *} 467.10^{* *}} 73.96^{*} 224.25^{* *} 370.56^{* *}$

\section{Interaction effects}

$\begin{array}{lllllll}P-L \times Z n & i & 8.60 & 12.70 & 5.60 & 11.06 & 1.58 \\ P \rightarrow Q \times Z n & 1 & 42.50 & 0.07 & 8.27 & 36.57 & 53.18 \\ P-C \times Z n & 1 & 29.85 & 2.92 & 0.38 & 15.02 & 33.93 \\ \text { Error } & 8 & 11.68 & 14.67 & 12.43 & 19.24 & 18.96\end{array}$

* ${ }^{* *}$ Indicate 0.05 and 0.01 significance 1 evels, respectively. 
Tris

17 Mean squares from the analysis of variance $f$ or the $2 n$ derived from fertilizer ( $\%$ Zndff) by beans grown on the Carrot River and Meota soils.

\begin{tabular}{|c|c|c|c|c|c|c|}
\hline \multirow{2}{*}{ Source } & \multirow{2}{*}{$d f$} & \multicolumn{2}{|c|}{$1 / 10$ bloom stage } & \multicolumn{3}{|c|}{ Maturity } \\
\hline & & Roots & Tops & Roots & Seeds & Straw \\
\hline P effects & & \multicolumn{5}{|c|}{ Carrot River } \\
\hline$P$ linear $(P-L)$ & 1 & $26.29^{*}$ & $45.86^{*}$ & 21.73 & $125.96^{*}$ & 5.44 \\
\hline$P$ quadratic $(P-Q)$ & 1 & 1.38 & 14.01 & 1.19 & 18.65 & 0.53 \\
\hline$P$ cubic $(P-C)$ & 1 & 10.38 & 0.85 & 4.65 & 7.20 & 0.06 \\
\hline Error & 4 & 2.32 & 3.20 & 4.23 & 2.70 & 3.29 \\
\hline$P$ effects & & & & Meota & & \\
\hline$P$ linear $(P-L)$ & 1 & $544.89^{* *}$ & $54.03^{*}$ & $55.27^{* *}$ & 0.04 & 7.69 \\
\hline$P$ quadratic $(P-Q)$ & 1 & $239.50^{* *}$ & 7.73 & $50.24^{* *}$ & 0.69 & 16.64 \\
\hline$P$ cubic $(P-C)$ & 1 & $61.59^{* *}$ & 5.89 & 6.43 & 0.00 & 0.19 \\
\hline Error & 3 & 2.03 & 3.61 & 2.27 & 4.40 & 4.19 \\
\hline
\end{tabular}

* ${ }^{* *}$ Indicate 0.05 and 0.01 significance levels, respectively. 
Table . 18 Mean squares from the analysis of variance for the $P$ derived from fertilizer (\% Pdff) by beans at $1 / 10$ bloom stage grown on the Sutherland soil.

\begin{tabular}{|c|c|c|c|}
\hline Sour ce & $d f$ & Roots & Tops \\
\hline
\end{tabular}

\section{P effects}
P Inear $(\mathrm{P}-\mathrm{L})$
1
$3282.93^{* *}$
$1474.65^{* *}$
$P$ quadratic $(P-Q)$
$60.35^{* *}$
13.12

\section{Zn effects}

$\begin{array}{cccc}Z n \text { linear }(\mathrm{Zn}-\mathrm{L}) & 1 & 62.56^{* *} & 7.05 \\ \text { Zn quadratic }(Z n-Q) & 1 & 0.03 & 2.56\end{array}$

\section{Interaction effects}

$\begin{array}{lccc}P-L \times Z n-L & 1 & 0.64 & 0.38 \\ P-L \times Z n-Q & 1 & 0.12 & 2.09 \\ P-Q \times Z n-L & 1 & 4.80 & 0.03 \\ P-Q \times Z n-Q & 1 & 1.10 & 1.84 \\ \text { Error } & 8 & 3.50 & 3.67\end{array}$

* ${ }^{* *}$ Indicate 0.05 and 0.01 significance levels, respectively. 
Tar $1 \geq 19$ ilean squares from the analysis of variance for the $P$ derived from fertilizer ( $*$ Pdf $f$ ) by beans at $1 / 10$ bloom stage in Carrot $\because r$ and Meota soils.

Sous df $\frac{\text { Carrot River }}{\text { Roots }}$ Tops $\frac{\text { Meota }}{\text { Roots Tops }}$

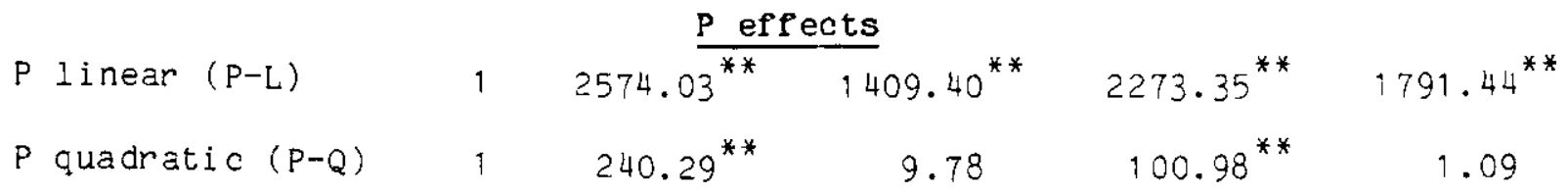

ovs. $5(2 n)$

\section{Interaction effects}

\begin{tabular}{llllll} 
P-L X Zn & 1 & 7.04 & 0.01 & 8.78 & 0.44 \\
P-Q $X$ Zn & 1 & 1.14 & 2.32 & 2.40 & 0.45 \\
Error & 6 & 2.69 & 2.09 & -1.70 & 2.75 \\
\hline
\end{tabular}

* ** Indicate 0.05 and 0.01 significance levels, respectively. 